\title{
AVALIAÇÕES MICROCLIMÁTICAS, FENOLÓGICAS E AGRONÔMICAS EM CAFÉ ARÁBICA CULTIVADO A PLENO SOL E CONSORCIADO COM BANANA 'PRATA ANÃ'
}

\author{
JOSÉ RICARDO MACEDO PEZZOPANE
}

Tese apresentada à Escola Superior de Agricultura "Luiz de Queiroz", Universidade de São Paulo, para obtenção do título de Doutor em Agronomia, Área de Concentração: Física do Ambiente Agrícola

PIR A C I C A B A

Estado de São Paulo - Brasil

Dezembro - 2004 


\section{AVALIAÇÕES MICROCLIMÁTICAS, FENOLÓGICAS E AGRONÔMICAS EM CAFÉ ARÁBICA CULTIVADO A PLENO SOL E CONSORCIADO COM BANANA 'PRATA ANÃ'}

José RicARdo MACEDO PEZZOPANE

Engenheiro Agrônomo

Orientador: Dr. MÁRIO JOSÉ PEDRO JÚNIOR

Tese apresentada à Escola Superior de Agricultura "Luiz de Queiroz", Universidade de São Paulo, para obtenção do título de Doutor em Agronomia, Área de Concentração: Física do Ambiente Agrícola

PIR A C I C A B A

Estado de São Paulo - Brasil

Dezembro - 2004 
Dados Internacionais de Catalogação na Publicação (CIP) DIVISÃO DE BIBLIOTECAE DOCUMENTAÇÄO - ESALQ/USP

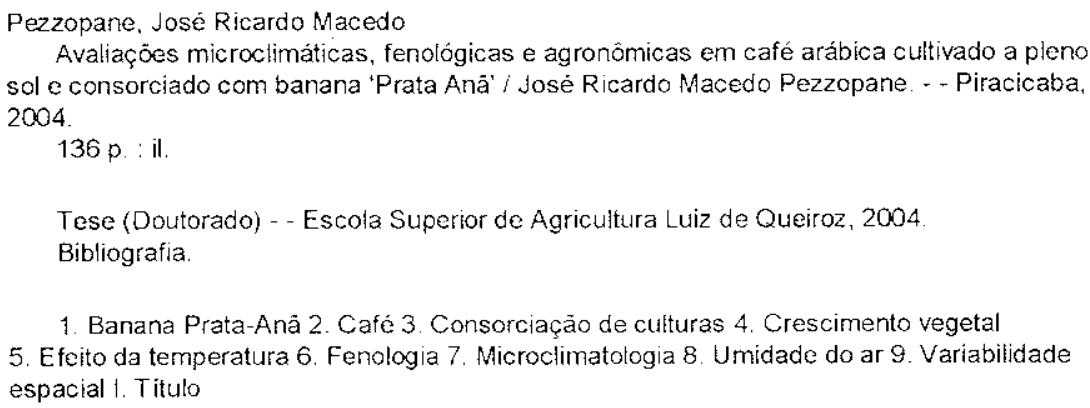

CDD 633.73

Permitida a cópia total ou parcial deste documento, des de que citada a forte 0 autor: 
Aos meus pais,

ATHENOGENES e MARISA,

\section{OFEREÇO}

À minha esposa CRISTIANA, com muito amor, 


\section{AGRADECIMENTOS}

Ao Dr. Mário José Pedro Júnior, do Instituto Agronômico de Campinas, pela orientação, apoio e valiosa amizade.

À Escola Superior de Agricultura "Luiz de Queiroz", pela oportunidade para a realização do curso.

À Fundação de Amparo a Pesquisa do Estado de São Paulo, pela concessão da Bolsa de Estudos e pelo suporte financeiro para a instalação e condução do experimento.

Ao Consórcio Brasileiro de Pesquisa e Desenvolvimento do Café (CNP\&D - Café), pelos recursos financeiros para a condução dos experimentos.

Ao Polo Regional de Desenvolvimento Tecnológico dos Agronegócios do Nordeste Paulista, da APTA, pela oportunidade de instalação e manutenção dos experimentos.

Ao Centro de Café "Alcides Carvalho" e ao Centro de Ecofisiologia e Biofísica, do Instituto Agronômico de Campinas, pela oportunidade concedida, apoio e cessão de equipamentos utilizados no presente trabalho.

Ao Professor Paulo César Sentelhas, pelo apoio em todos os momentos, pelos ensinamentos e pela valiosa amizade.

Aos Pesquisadores Científicos Paulo Boller Gallo, Ângelo Paes de Camargo, Marcelo Bento Paes de Camargo, Luiz Carlos Fazuoli e Altino Aldo Ortolani, pelas sugestões e apoio constante.

Á Romilson Cesar Moraes Yamamura, do Centro de Ecofisiologia e Biofísica, pela amizade, auxilio na instalação e condução do experimento.

Aos funcionários do Polo Regional de Desenvolvimento Tecnológico dos Agronegócios do Nordeste Paulista, em especial à Ronaldo Eduardo da Silva e Sérgio José Coradello, pelo auxílio na instalação e condução dos experimentos.

Aos funcionários do Centro de Café "Alcides Carvalho", do IAC, em especial à Dona Ivone, pela constante ajuda.

Aos funcionários do Centro de Ecofisiologia e Biofísica, do IAC, pelo auxílio na instalação e condução dos experimentos. 
Aos Professores, funcionários e alunos do Departamento de Ciências Exatas da ESALQ, pela colaboração e apoio.

Aos meus irmãos, cunhados, sobrinhos, amigos e familiares que sempre me apoiaram e incentivaram.

À minha esposa Cristiana, por seu amor e apoio incondicional nessa etapa da minha vida. 


\section{SUMÁRIO}

Página

LISTA DE FIGURAS.......................................................................

LISTA DE TABELAS...................................................................... x xi

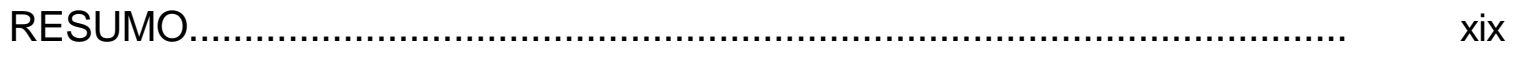

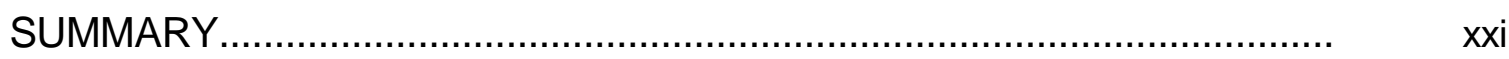

1 INTRODUÇÃO

2 REVISÃO DE LITERATURA.................................................................

2.1 Requerimentos climáticos do cafeeiro (Coffea arabica L.)................................ 3

2.2 Fenologia do cafeeiro.....................................................................................

2.3 Microclima de cultivos.............................................................................

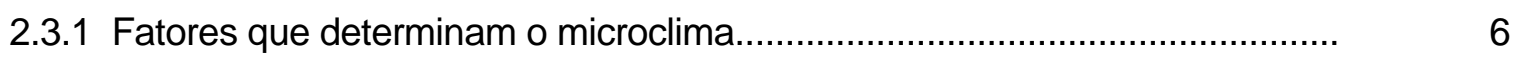

2.3.2 Interações microclimáticas em comunidades vegetais.....................................

2.3.3 Método da razão de Bowen....................................................................

2.4 Microclima em cultivos arborizados e protegidos por quebra-ventos.................. 9

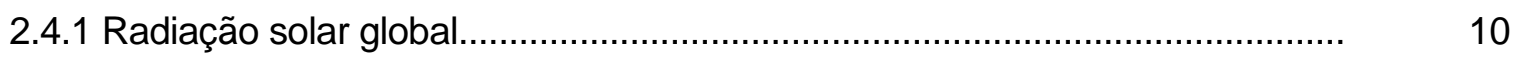

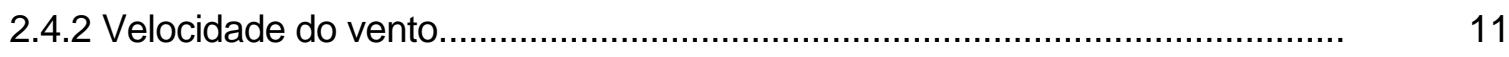

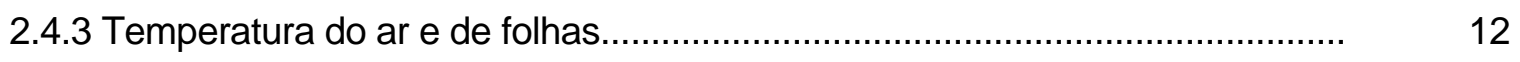

2.4.4 Umidade relativa do ar..................................................................... 15

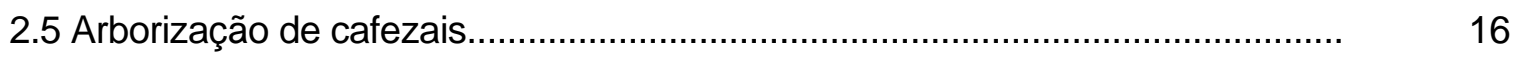

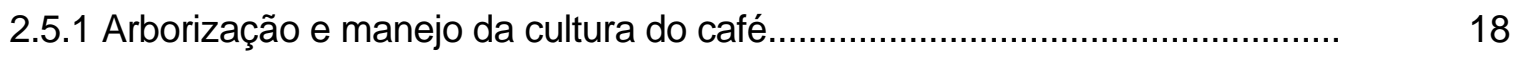

2.5.2 Arborização e produtividade do cafeeiro..................................................... 20

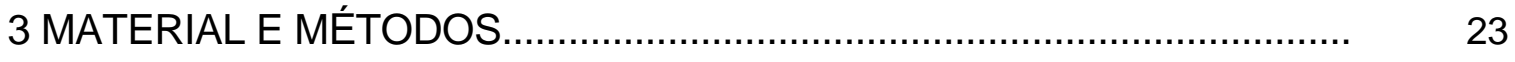

3.1 Caracterização da área experimental................................................................ 23 


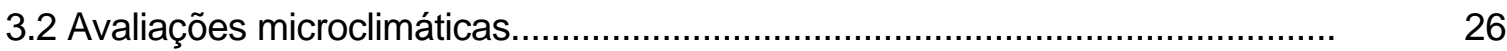

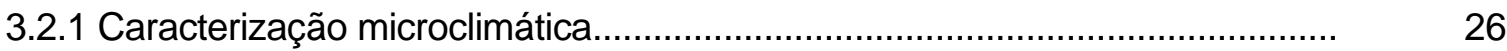

3.2.2 Análise microclimática durante episódios de resfriamento do ar...................... 29

3.2.3 Características aerodinâmicas e energéticas................................................ 31

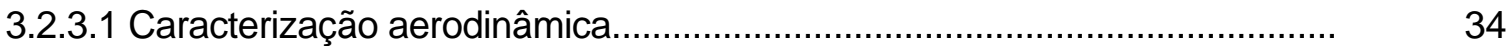

3.2.3.2 Balanço de energia .............................................................................. 35

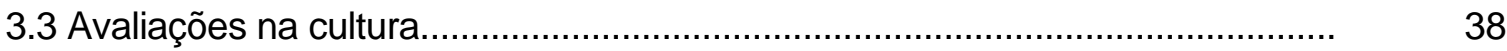

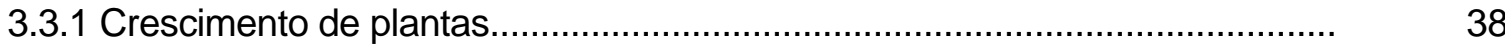

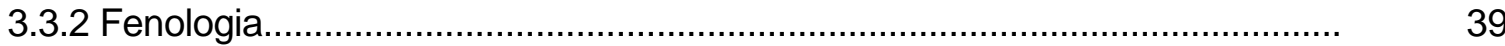

3.3.2.1 Elaboração de escala fenológica................................................................. 39

3.3.2.1 Desenvolvimento fenológico..................................................................... 39

3.3.3 Índices de Produção............................................................................... 40

3.3.3.1 Produção e rendimento........................................................................... 40

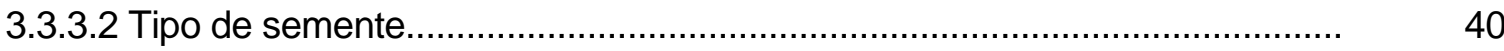

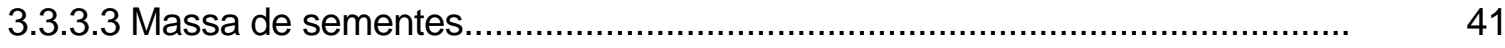

3.3.4 Análise estatística......................................................................................

4 RESULTADOS E DISCUSSÃO.............................................................. 42

4.1 Condições meteorológicas durante o período experimental............................... 42

4.2 Caracterização microclimática........................................................................

4.2.1 Energia radiante e balanço de radiação........................................................

4.2.1.1 Radiação solar global..........................................................................

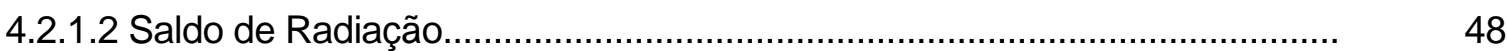

4.2.1.3 Relações entre Saldo de radiação e Radiação solar global.......................... 54

4.2.2 Velocidade do vento.................................................................................... 56

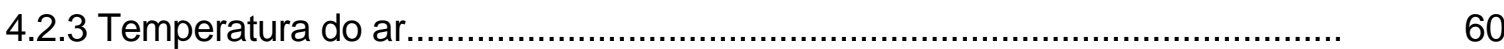

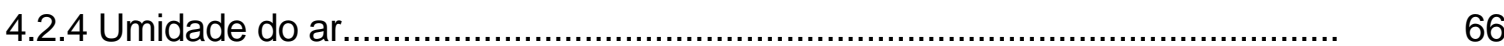

4.3 Análise microclimática durante episódios de resfriamento do ar......................... 71

4.4 Características aerodinâmicas e energéticas.....................................................

4.4.1 Perfis de vento...........................................................................................

4.4.2 Perfis de temperatura e umidade.................................................................... 81

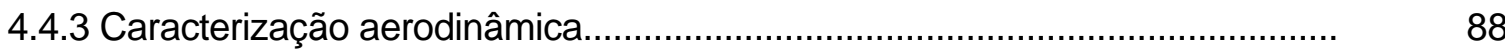

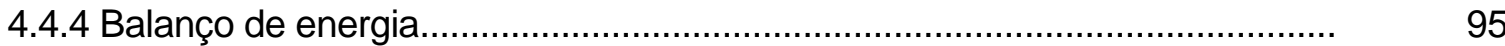

4.5 Crescimento, fenologia e produção dos cafeeiros............................................. 102 


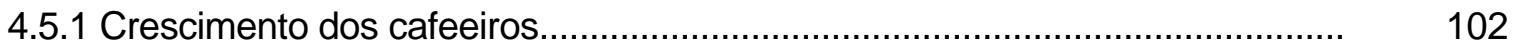

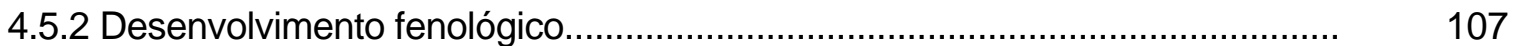

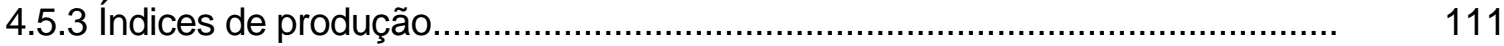

4.5.3.1 Índices de produção nos cultivos de café a pleno sol e consorciado com banana 'Prata Anã'.

4.5.3.2 Variabilidade espacial dos índices de produção no cultivo de café consorciado com banana 'Prata Anã'.....

5 CONCLUSÕES

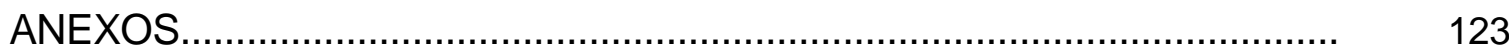

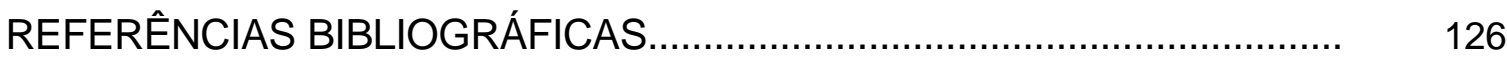




\section{LISTA DE FIGURAS}

Página

1 Esquematização as seis fases fenológicas do cafeeiro arábica, durante 24 meses, nas condições climáticas tropicais do Brasil (extraído de Camargo \& Camargo, 2001).

2 Valores mensais de precipitação pluvial e temperatura do $\operatorname{ar}(\mathrm{A})$ e extrato do balanço hídrico climatológico (B) de Mococa, SP, a partir de dados normais do período de 1961-1990 e considerando CAD de $100 \mathrm{~mm}$.

3 Representação esquemática das parcelas experimentais de cultivo de café em sistema de monocultivo $(A)$ e consorciado com banana 'Prata Anã' (B).

$4 \quad$ Vista da parcela de café consorciada com banana 'Prata Anã', nos meses de junho de 2001 (A), outubro de 2001 (B), setembro de 2002 (C) e dezembro de 2003 (D), em Mococa, SP.

5 Representação esquemática da posição de instalação de sensores na parcela consorciada em relação a planta de banana.

6 Vista da instalação dos sensores na parcela de café consorciada com banana 'Prata Anã', em Mococa, SP

7 Representação esquemática de instalação de sensores durante o período de inverno na parcela consorciada em relação a uma planta de banana.

8 Vista da instalação dos sensores para obtenção dos perfis no sistema consorciado $(A, B)$ e cultivo a pleno sol $(D, E)$, com detalhe dos braços com psicrômetro e anemômetro e saldo radiômetro $(\mathrm{C})$

9 Representação esquemática da parcela útil para fins de avaliação de produção e detalhamento da posição individual de plantas de café dentro da parcela consorciada.

10 Extrato do balanço hídrico $(C A D=100 \mathrm{~mm})$, durante os meses de julho de 2001 a dezembro de 2002 (A) e janeiro de 2003 a junho de 2004 (B), em Mococa, SP. 
11 Variação sazonal da relação entre a radiação solar global no cultivo de café consorciado (RG consorciado) e no cultivo de café a pleno sol (RG Pleno sol), em Mococa, SP, no período de outubro de 2001 a setembro de 2002 .

12 Variação dos valores horários da radiação solar global $(R G)$ em cultivo de café a pleno sol e em diferentes pontos amostrais de cultivo de café consorciado com banana 'Prata Anã', em Mococa, SP, nos dias 6/11/2001 (A), 5/2/2002 (B), 15/6/2002 (C) e 18/8/2002 (D).....

13 Comparação entre os valores diários da radiação solar global $\left(\mathrm{MJ}_{\mathrm{m}} \mathrm{m}^{-2} \cdot \mathrm{dia}^{-1}\right)$ em cultivo de café a pleno sol e consorciado com bananeira 'Prata Anã' (média dos pontos amostrais), em Mococa, SP, no período de outubro de 2001 a setembro de 2002.

14 Variação sazonal da relação entre o Saldo de Radiação em diferentes pontos amostrais de cultivo de café consorciado (SR consorciado) e o Saldo de Radiação no cultivo a Pleno Sol (SR Pleno sol), no período de outubro de 2001 a setembro de 2002, em Mococa, SP

15 Variação dos valores horários do saldo de radiação em cultivo de café a pleno sol e em diferentes pontos amostrais de cultivo de café consorciado com banana 'Prata Anã', em Mococa, SP, nos dias 28/10/2001 (A), 26/7/2002 (B), característicos de céu limpo e 23/11/2001 (C) e 23/7/2002 (D), nublados

16 Relação entre os valores diários do saldo de radiação $\left(\mathrm{MJ} \cdot \mathrm{m}^{-2} \cdot\right.$ dia $\left.^{-1}\right)$ em cultivo de café a pleno sol e em cultivo de café consorciado com bananeira 'Prata Anã' (média dos pontos amostrais), em Mococa, SP, no período de outubro de 2001 a setembro de 2002.

17 Comparação entre os valores diários do saldo de radiação e a radiação solar global no cultivo de café a pleno sol nos meses de janeiro $(A)$ e junho $(C)$ de 2002 e consorciado com bananeira 'Prata Anã', nos meses de janeiro (B) e julho (D) de 2002, em Mococa, SP

18 Médias quinquidiais da velocidade do vento $\left(\mathrm{m}^{-1} \mathrm{~s}^{-1}\right)$ em cultivos de café a pleno sol e consorciado com banana 'Prata Anã', em Mococa, SP.

19 Comparação entre os valores diários da velocidade do vento $\left(\mathrm{m} . \mathrm{s}^{-1}\right)$ em cultivos de café a pleno sol e em diferentes pontos amostrais de cultivo de café consorciado com bananeira 'Prata Anã', para quatro estações do ano, em Mococa, SP.... 
20 Comparação entre os valores quinquidiais de temperatura máxima ( $A$ e B), temperatura mínima ( $C$ e D) e temperatura média ( $E$ e F) do ar em cultivos de café a pleno sol e em diferentes pontos amostrais de cultivo café consorciado com bananeira 'Prata Anã', para quatro estações do ano, em Mococa, SP.

21 Variação dos valores horários da temperatura do ar em cultivo de café a pleno sol e consorciado com banana 'Prata Anã', em Mococa, SP, nos dias 6/11/2001 (A), 16/4/2002 (B), 18/8/2002 (C) e 27/9/2002 (D)

22 Comparação entre os valores quinqüidiais da umidade relativa (A e $B)$, défice de pressão de vapor (C e D) e pressão atual de vapor ( $E$ e F) do ar em cultivos de café a pleno sol e em diferentes pontos amostrais de cultivo café consorciado com bananeira 'Prata Anã', para quatro estações do ano, em Mococa, SP.

23 Variação dos valores horários da pressão atual de vapor em cultivo de café a pleno sol e em diferentes pontos amostrais de cultivo de café consorciado com banana 'Prata Anã', em Mococa, SP, nos dias 6/11/2001 (A), 16/4/2002 (B), 18/08/2002 (C) e 27/9/2002 (D).

24 Temperatura do ar $(A)$, temperatura da folha $(B)$, saldo de radiação (C) e velocidade do vento (D) em cultivo de café a pleno sol e em diferentes pontos amostrais de cultivo de café consorciado com banana 'Prata Anã', nos dias 8 a 10 de julho de 2002, em Mococa, SP.

25 Temperatura do ar $(\mathrm{A})$, temperatura da folha $(\mathrm{B})$, saldo de radiação (C) e velocidade do vento (D) em cultivo de café a pleno sol e em diferentes pontos amostrais de cultivo de café consorciado com banana 'Prata Anã', nos dias 17 a 19 de agosto de 2003, em Mococa, SP.

26 Perfis médios da velocidade do vento $\left(\mathrm{m}^{\mathrm{s}} \mathrm{s}^{-1}\right)$ no cultivo de café a pleno sol, durante os períodos de 11-16/1/2003 e 7-10/02/2002 (A) e 26-31/7/2003 e 30/9-6/10/2003 (B), em Mococa, SP.

27 Perfis médios da velocidade do vento $\left(\mathrm{m}_{\mathrm{s}} \mathrm{s}^{-1}\right)$, a cada duas horas, no cultivo de café a pleno sol, nos dias 10 de fevereiro (A) e 3 de outubro de 2003 (B), em Mococa, SP....

28 Perfis médios $(A)$ e normalizados $\left(u / u_{0}\right)(B)$ da velocidade do vento no cultivo consorciado de café com banana 'Prata Anã', durante cinco períodos de medidas, em Mococa, SP... 
29 Perfis médios da velocidade do vento $\left(\mathrm{m} \cdot \mathrm{s}^{-1}\right)$, a cada duas horas, no cultivo consorciado de café com banana 'Prata Anã', nos dias 3 de julho (A) e 6 de novembro de 2003 (B), em Mococa, SP....

30 Perfis médios horários da temperatura do ar $\left({ }^{\circ} \mathrm{C}\right)(\mathrm{A})$ e pressão atual de vapor $(\mathrm{kPa})(\mathrm{B})$, no cultivo de café a pleno sol, no dia 10 de fevereiro de 2003, em Mococa, SP...

31 Perfis médios horários da temperatura do ar $\left({ }^{\circ} \mathrm{C}\right)(\mathrm{A})$ e pressão atual de vapor $(\mathrm{kPa})(\mathrm{B})$, no cultivo de café a pleno sol, no dia 3 de outubro de 2003, em Mococa, SP

32 Perfis médios horários da temperatura do ar $\left({ }^{\circ} \mathrm{C}\right)(\mathrm{A})$ e pressão atual de vapor $(\mathrm{kPa})(\mathrm{B})$, no cultivo de café consorciado com banana 'Prata Anã', no dia 13/12/2002, em Mococa, SP.

33 Perfis médios horários da temperatura do ar $\left({ }^{\circ} \mathrm{C}\right)(\mathrm{A})$ e pressão atual de vapor $(\mathrm{kPa})(\mathrm{B})$, no cultivo de café consorciado com banana 'Prata Anã', no dia 3/7/2003, em Mococa, SP

34 Perfis médios horários da temperatura do $\operatorname{ar}\left({ }^{\circ} \mathrm{C}\right)(\mathrm{A})$ e pressão atual de vapor $(\mathrm{kPa})(\mathrm{B})$, no cultivo de café consorciado com banana 'Prata Anã', no dia 6/11/2003, em Mococa, SP.

35 Relação do deslocamento do plano zero $(d)$ e do comprimento da rugosidade da superfície $\left(z_{0}\right)$ com a velocidade característica do vento $\left(u^{*}\right)$ nos períodos de 11-16/1/2003 e 7-10/2/2003 com direção do vento no sentido transversal dos renques (A e B) e direção no sentido dos renques ( $C$ e $D)$ e nos períodos de $26-31 / 7 / 2003$ e 30/96/10/2003 com direção do vento no sentido transversal dos renques $(E$ e $F)$ e direção no sentido dos renques $(G$ e H) em cultivo de café a pleno sol em Mococa,SP.

36 Relação do deslocamento do plano zero $(d)$ e do comprimento da rugosidade da superfície $\left(z_{0}\right)$ com a velocidade característica do vento $\left(u^{*}\right)$ nos períodos de 11-17/12/2002, 26-30/3/2003 e 1620/4/2003 com direção do vento no sentido transversal dos renques ( $A$ e B) e direção no sentido dos renques (C e D); no período de 29/7/2003 com direção do vento no sentido transversal dos renques (E e F) e direção no sentido dos renques $(\mathrm{G}$ e H) e no período de 410/11/2003 com direção no sentido transversal dos renques (I e J) em cultivo de café consorciado com banana 'Prata Anã' em Mococa,SP.

37 Variação horária do saldo de radiação (SR), do fluxo de calor latente (LE), do fluxo de calor sensível $(H)$, do fluxo de calor no solo (FS) e da razão de Bowen ( $\beta$ ) nos dias 10/2/2003 (A) e 29/7/2003, em cultivo de café a pleno sol, em Mococa, SP..... 
38 Variação horária do saldo de radiação (SR), do fluxo de calor latente (LE), do fluxo de calor sensível $(H)$, do fluxo de calor no solo (FS) e da razão de Bowen ( $\beta$ ) nos dias 13/12/2002 (A) e 3/7/2003 (B), em cultivo de café consorciado com banana 'Prata Anã', em Mococa, SP.

39 Relação entre a evapotranspiração de referência (ETo) e a evapotranspiração da cultura (Etr), para o cultivo a pleno sol (A) e o cultivo consorciado (B) em diferentes épocas do ano.

40 Crescimento médio em altura (A) e diâmetro da copa (B) em quatro pontos amostrais de cultivo de café consorciado com banana 'Prata Anã', bem como sua média, e em cultivo de café a pleno sol, durante os meses de setembro de 2001 a abril de 2004.

41 Taxas de crescimento em altura do ramo plagiotrópico (A) e diâmetro máximo da copa $(B)$ de cafeeiros em quatro pontos de amostragem em cultivo consorciado de café com banana 'Prata Anã', bem como sua média e em cultivo de café a pleno sol, em cinco períodos, em Mococa, SP

42 Intervalos de confiança para taxas de crescimento em altura do ramo plagiotrópico ( $A$ a $E$ ) e diâmetro máximo da copa ( $F$ a J) de cafeeiros em quatro pontos de amostragem em cultivo consorciado de café com banana 'Prata Anã' (P1 a P4), bem como sua média e em cultivo de café a pleno sol (Sol), em cinco períodos, em Mococa, SP

43 Épocas de ocorrência de estádios fenológicos de cafeeiro, para a florada principal, em quatro pontos do amostragem em cultivo consorciado de café com banana 'Prata Anã' (P1 a P4), bem como sua média e no cultivo de café a pleno sol (Sol) nos anos agrícolas de 2001/2002 (A), 2002/2003 (B) e 2003/2004 (C).

44 Produção de café, expressa em $\mathrm{kg}$ de café da roça por $320 \mathrm{~m}^{2}$, e intervalos de confiança (95\%), para os sistemas de produção de café a pleno sol e consorciado com banana 'Prata Anã' nos anos de 2002 (A), 2003 (B) e 2004 (C), em Mococa, SP...

45 Rendimento do café (\%) e intervalos de confiança (95\%), para os sistemas de produção de café a pleno sol e consorciado com banana 'Prata Anã' nos anos de 2002 (A), 2003 (B) e 2004 (C), em Mococa, SP.

46 Massa de 100 sementes (gramas) e intervalos de confiança (95\%), para os sistemas de produção de café a pleno sol e consorciado com banana 'Prata Anã' nos anos de 2002 (A), 2003 (B) e 2004 (C), em Mococa, SP. 
47 Produção de café (total dos anos 2002-2004 - A), rendimento (média dos anos 2002-2004 - B) e massa de 100 sementes (média dos anos 2002-2004 - C), e intervalos de confiança (95\%), para os sistemas de produção de café a pleno sol e consorciado com banana 'Prata Anã', em Mococa, SP

48 Distribuição percentual dos tipos de sementes para os sistemas de produção de café a pleno sol e consorciado com banana 'Prata Anã' nos anos de 2002 (A), 2003 (B) e 2004 (C), e médias do período 2002-2004 (B), em Mococa, SP.

49 Distribuição percentual dos tipos de sementes para os diferentes pontos amostrais no cultivo de café consorciado com banana 'Prata Anã' nos anos de 2002 (A), 2003 (B) e 2004 (C), e médias do período 2002-2004 (B), em Mococa, SP 


\section{LISTA DE TABELAS}

Página

1 Altura de instalação de psicrômetros e anemômetros em dois sistemas de cultivo de café, em Mococa, SP

2 Altura média do dossel das plantas de café e bananeira nos diferentes períodos amostrais em experimento de café a pleno sol e consorciado com bananeira 'Prata Anã', em Mococa, SP......

3 Valores médios mensais de radiação solar global $\left(\mathrm{MJ}^{\mathrm{m}} \mathrm{m}^{-2} \cdot \mathrm{dia}^{-1}\right)$ em cultivo de café a pleno sol e em diferentes pontos amostrais de cultivo de café consorciado com bananeira 'Prata Anã', em Mococa, SP, no período de outubro de 2001 a setembro de 2002.

4 Dados mensais do saldo de radiação (SR - MJ.m ${ }^{-2} \cdot$ dia $^{-1}$ ) em um cultivo de café a pleno sol e em diferentes pontos amostrais de cultivo de café consorciado com bananeira 'Prata Anã', em Mococa, SP, no período de outubro de 2001 a setembro de 2002.

5 Valores diários do saldo de radiação $\left(\mathrm{MJ} \mathrm{m}^{-2} \cdot \mathrm{dia}^{-1}\right)$ em um cultivo de café a pleno sol e em diferentes pontos amostrais de café consorciado com bananeira 'Prata Anã', em Mococa, SP, para quatro episódios selecionados.

6 Variação sazonal das relações entre saldo de radiação diário (SR) e radiação solar global (RG) nos cultivos de café a pleno sol e consorciado com bananeira 'Prata Anã', em Mococa, SP, no período de outubro de 2001 a setembro de 2002. SP. Valores entre parênteses indicam o $R^{2}$

7 Valores mensais de velocidade do vento $\left(m \cdot s^{-1}\right)$, em um cultivo de café a pleno sol e consorciado com bananeira 'Prata Anã', em Mococa, SP, no período de outubro de 2001 a setembro de 2002.

8 Médias da velocidade do vento $\left(\mathrm{m} . \mathrm{s}^{-1}\right)$ e valores do teste $\mathrm{t}$ de comparação de médias, em cultivo de café a pleno sol e em diferentes pontos amostrais de cultivo café consorciado com bananeira 'Prata Anã', em Mococa, SP, avaliadas em quatro estações do ano. 
9 Médias das temperaturas máxima, mínima e média $\left({ }^{\circ} \mathrm{C}\right)$ e valores do teste t de comparação de médias, em cultivo de café a pleno sol e em diferentes pontos amostrais de cultivo café consorciado com bananeira 'Prata Anã', em Mococa, SP, avaliadas em quatro estações do ano.

10 Médias da umidade relativa do ar (\%), défice de saturação $(\mathrm{kPa})$ e pressão atual de vapor $(\mathrm{kPa})$ e valores do teste t de comparação de médias, em cultivo de café a pleno sol e em diferentes pontos amostrais de cultivo café consorciado com bananeira 'Prata Anã', em Mococa, SP, avaliadas em quatro estações do ano.

11 Valores diários de temperatura do ar e folha $\left({ }^{\circ} \mathrm{C}\right)$ e do saldo de radiação (MJ. $\mathrm{m}^{-2}$ ) em cultivo de café a pleno sol e em diferentes pontos amostrais de cultivo de café consorciado com bananeira 'Prata Anã', em Mococa, SP, durante o período de 8 a 10 de julho de 2002

12 Valores diários de temperatura do ar e folha $\left({ }^{\circ} \mathrm{C}\right)$ e do saldo de radiação (MJ.m ${ }^{-2}$ ) em cultivo de café a pleno sol e em diferentes pontos amostrais de cultivo de café consorciado com bananeira 'Prata Anã', em Mococa, SP, durante o período de 17 a 19 de agosto de 2003.

13 Estimativas dos parâmetros velocidade característica $\left(u^{*}\right)$, deslocamento do plano zero $(d)$, comprimento da rugosidade $\left(z_{0}\right)$, e suas relações com o topo da cultura $(H)$, para diferentes períodos de medição e de direção de vento predominante, em cultiivo de café a pleno sol, em Mococa, SP

14 Estimativas dos parâmetros velocidade característica $\left(u^{*}\right)$, deslocamento do plano zero $(d)$, comprimento da rugosidade $\left(z_{0}\right)$, e suas relações com o topo da cultura $(H)$, para diferentes períodos de medidas e direção de vento predominante, em cultivo de café consorciado com banana 'Prata Anã', em Mococa, SP

15 Variação diária dos valores de saldo de radiação (SR), fluxo de calor latente $(\lambda E)$, fluxo de calor sensível $(H)$ e fluxo de calor para o solo (FS) $\left(\mathrm{MJ}^{-\mathrm{m}^{-2}} \cdot \mathrm{dia}^{-1}\right)$, em período diurno, e relações de $\lambda \mathrm{E}, \mathrm{H}$ e FS com SR, durante duas épocas do ano, em cultivo de café a pleno sol, em Mococa, SP.

16 Variação diária dos valores de saldo de radiação (SR), fluxo de calor latente $(\lambda E)$, fluxo de calor sensível $(H)$ e fluxo de calor para o solo (FS)(MJ.m ${ }^{-2} \cdot$ dia $\left.^{-1}\right)$, em período diurno, e relações de $\lambda E, H$ e FS com $\mathrm{SR}$, durante duas épocas do ano, em cultivo de café consorciado com banana 'Prata Anã', em Mococa, SP 
17 Produção de café ( $\mathrm{kg}$ de café da roça $/ 320 \mathrm{~m}^{2}$ ), rendimento (\%) e massa de 100 sementes (gramas) em cultivo de café a pleno sol e consorciado com banana 'Prata Anã' nos anos de 2002, 2003 e 2004, em Mococa, SP.

18 Produção de café (kg de café beneficiado/planta), rendimento (\%) e massa de 100 sementes (gramas) em quatro pontos amostrais no cultivo de café consorciado com banana 'Prata Anã' nos anos de 2002, 2003 e 2004, em Mococa, SP. 


\title{
AVALIAÇÕES MICROCLIMÁTICAS, FENOLÓGICAS E AGRONÔMICAS EM CAFÉ ARÁBICA CULTIVADO A PLENO SOL E CONSORCIADO COM BANANA 'PRATA ANÃ'
}

\author{
Autor: JOSÉ RICARDO MACEDO PEZZOPANE \\ Orientador: Dr. MÁRIO JOSÉ PEDRO JUNIOR
}

\section{RESUMO}

O presente trabalho foi realizado em cafeeiros (Coffea arabica L.) cv. Icatu Vermelho IAC 4045, cultivados a pleno sol e consorciados com banana 'Prata Anã' (Musa AAB), em Mococa - SP (Latitude 21ㅇ 28' S, Longitude 47웅' W, altitude 665m). Foi realizada a caracterização microclimática, entre outubro de 2001 e setembro de 2002, onde foram medidos a radiação solar global, saldo de radiação, velocidade do vento e temperatura e umidade relativa do ar nos dois sistemas de cultivo. No período do inverno de 2002 e 2003, foi realizado um estudo da influência das bananeiras na variabilidade espacial da temperatura do ar e folha, além do saldo de radiação, em episódios de resfriamento noturno. Realizou-se também uma caracterização aerodinâmica e energética dos cultivos, entre dezembro de 2002 e novembro de 2003, onde foram obtidos os perfis dos bulbos seco e úmido, além da velocidade do vento em sete níveis de medida. Entre julho de 2001 a junho de 2004 foram atribuídas notas de desenvolvimento fenológico dos cultivos, além de se avaliar, o crescimento das plantas em altura e diâmetro da copa. Nas safras de 2002, 2003 e 2004 foram avaliados os parâmetros de produção nos dois sistemas de cultivo, além da variabilidade desses nas parcelas do cultivo consorciado. Houve uma atenuação dos valores de radiação solar global (21\%) no cultivo de café consorciado e uma redução de $16 \%$ e $48 \%$ nos valores do saldo de radiação e velocidade do vento, em relação ao cultivo a pleno sol. Com relação à temperatura e umidade do ar, foram encontradas diferenças apenas na temperatura máxima no ponto central da parcela 
do cultivo consorciado, que apresentou médias superiores em relação ao cultivo a pleno sol no verão e outono, e em relação ao ponto situado próximo as bananeiras na primavera, verão e outono. Nos episódios de resfriamento do ar no período noturno, apesar do cultivo consorciado apresentar menor perda radiativa, ocorreu apenas um acréscimo de $0,3^{\circ} \mathrm{C}$ na temperatura do ar nos episódios amostrados, sendo que para a temperatura das folhas esses valores atingiram até $0,5^{\circ} \mathrm{C}$. Foi verificado ainda que a ação de quebra-vento das bananeiras no cultivo consorciado, promoveu alterações nos perfis de temperatura e umidade do ar, apresentando gradientes reduzidos, em relação ao cultivo a pleno sol, acima do dossel dos cafeeiros. Os valores médios dos componentes do balanço de energia nos sistemas de cultivos de café a pleno sol e consorciado não apresentaram diferenças. Nos sistemas de cultivo avaliados, o crescimento vegetativo em altura e diâmetro apresentou maior atividade vegetativa no período primavera-verão em relação ao período outono-inverno, não tendo sido encontradas diferenças significativas das taxas de crescimento, de desenvolvimento fenológico e dos índices de produção entre os cultivos. No cultivo consorciado, o ponto amostral próximo às bananeiras apresentou diferenças em relação aos demais pontos amostrados no crescimento vegetativo e desenvolvimento fenológico para algumas épocas do ano, além de apresentar menor produção por planta e maior massa de 100 sementes. 


\title{
MICROCLIMATIC, PHENOLOGICAL AND AGRONOMIC EVALUATIONS IN COFFEE CROP GROWN UNDER UNSHADED AND SHADED BY 'PRATA ANÃ' BANANA PLANTS CONDITIONS
}

\author{
Author: JOSÉ RICARDO MACEDO PEZZOPANE \\ Adviser: Dr. MÁRIO JOSÉ PEDRO JUNIOR
}

\section{SUMMARY}

A study was carried out in coffee crop (Coffea arabica L.) cv. Icatu Vermelho IAC 4045, unshade and shaded by banana 'Prata Anã' (Musa AAB), in Mococa, São Paulo State, Brazil (Latitude South 210 28 ', Longitude West 470 01 ', altitude 665m). The microclimatic measurements (solar radiation, net radiation, wind speed, air temperature and air moisture) were taken from October, 2001 to September, 2002 under different crops conditions. During the winter of 2002 and 2003, a study of the influence of the banana plants was done on space variability of air and leaf temperature, besides net radiation, for cold nights. The aerodynamic and energy characterization were done from December, 2002 to November,2003, by obtining the profiles of the bulb wet and dry air temperature, also measurements the wind speed in seven different levels. From July, 2001 to June, 2004 phenological data for the coffee crops were taken. The growth of the plants concerning height and diameter was also evaluated. The harvests of 2002, 2003 and 2004 were appraised by the production parameters, and their variability for different positions in shaded coffee crop. The banana trees reduced the incoming solar radiation to the coffee crop by $21 \%$, and by $16 \%$ and $48 \%$ in the values of the net radiation and wind speed, respectively. Concerning on air temperature and air mosture, differences were found just for the maximum air temperature at the central point of the shaded crop, showing higher averages in relation to the unshaded crop during the summer and autumn, and also in relation to the nearest point to the banana plants during the spring, summer and autumn. 
During cold nights, spite the shaded coffee crop showing smaller radiation loss, an increment of $0.3^{\circ} \mathrm{C}$ in the air temperature was observed and for the leaves the values reached $0.5^{\circ} \mathrm{C}$. It was verified an windbreak action of fanlight of the banana trees in the shaded crop, promoting deviation in air temperature and humidity profiles, showing reduced gradients, in relation to the unshaded crop, above the coffee plants canopy. The mean values of the energy balance components for the different systems of cultivation did not show difference. In the cultivation systems evaluated, the vegetative growth in height and diameter showed higher vegetative activity during the spring-summer period in relation to the autumn-winter period. No significant differences of the growth taxes, of phenological development and of the yield indexes were found. In coffee crop shaded, the nearest point to the banana plants showed differences in relation to the other amostral points in vegetative growth and phenological development for some seasons of the year, besides showing smaller plant yield and higher weight of 100 seeds. 


\section{INTRODUÇÃO}

O cafeeiro (Coffea arabica L.) é uma planta originária da Etiópia, onde se desenvolveu sob ambiente em sub-bosques de sombra moderada e sua adaptação neste ecossistema indica ser planta não tolerante a temperaturas extremas

No Brasil, o cultivo do café arábica se desenvolveu extensivamente em ambiente a pleno sol. Estes agrossistemas, predominantes também no Estado de São Paulo, apresentam cultivares selecionadas para alta produtividade, desde que se faça uso intensivo de insumos, e que são cultivadas basicamente em monocultivo em área extensas, de composição homogênea, apresentando inexistência de mecanismos de auto regulação e equilíbrio.

Esse tipo de exploração proporcionou em algumas regiões um caráter nômade da cafeicultura, apresentando como principais problemas a baixa produtividade, lavouras decadentes, alto custo de produção e baixo nível de adoção tecnológica, agravados por condições climáticas extremas, como ocorrência de geadas e secas prolongadas. Como conseqüência disso podem ser citadas as grandes extensões de solos erodidos e desequilibrados e a ocorrência generalizada de nematóides nas lavouras, propiciando uma cafeicultura marginal e com baixa sustentabilidade, nos quais os problemas nutricionais se tornam críticos e a oscilação da bienalidade da produção mais acentuada, levando às vezes a erradicação das lavouras.

O retorno da cafeicultura para essas regiões necessita de novas tecnologias e sistemas sustentáveis e mais produtivos com base em novas cultivares, melhor distribuição espacial de plantas, menor exposição do solo, correção dos solos e exploração da cultura em outros tipos de sistema de produção, como os cultivos consorciados ou arborizados.

A proposta de cultivos consorciados busca, por meio do sombreamento moderado, atenuar as ocorrências climáticas extremas e proporcionar maior sustentabilidade aos sistemas. Nesse contexto, acrescenta-se ainda a agregação de uma 
fonte de renda extra para os cafeicultores e melhor aproveitamento da mão-de-obra durante $\mathrm{o}$ ano, benefício de grande importância para a agricultura familiar. Diante dessa análise é possível verificar o grande potencial para a utilização da técnica de consorciação, principalmente em áreas de pequena extensão, visando auxiliar na melhoria da produtividade e sustentabilidade da produção.

O estudo das interações microclimáticas entre os componentes de um agrossistema e o ambiente, além da análise de crescimento e dos fatores de produção, são critérios básicos para as definições da viabilidade de cultivos consorciados na agricultura. Dentre as variáveis meteorológicas a serem estudadas, destaca-se a radiação solar, pois a sua disponibilidade, associada ao regime de vento, influenciam na variação da temperatura e umidade do ar, alterando o balanço de energia.

Considerando esses aspectos, aliado à necessidade de informações a respeito da caracterização microclimática de cultivos, o presente trabalho teve o objetivo avaliar as condições microclimáticas em cultivo de café a pleno sol e consorciado com banana 'Prata Anã'; caracterizar os gradientes de temperatura e umidade do ar e o perfil da velocidade do vento; verificar a variabilidade espacial da temperatura do ar e das folhas e do saldo de radiação em episódios de resfriamento noturno e avaliar o efeito do microclima no crescimento, desenvolvimento fenológico e índices de produção. 


\section{REVISÃO DE LITERATURA}

\subsection{Requerimentos climáticos do cafeeiro (Coffea arabica L.)}

O cafeeiro (Coffea arabica L.) é uma planta originária dos altiplanos da Etiópia, onde vegeta espontaneamente em sub-bosques nas regiões de Jimma e Kaffa, entre 6ำ e $9^{\circ} \mathrm{N}$, desde 1.600 a 1.900 metros de altitude, onde a temperatura do ar oscila entre $17^{\circ} \mathrm{e}$ $20^{\circ} \mathrm{C}$ e as chuvas anuais variam entre 1.500 a $1.800 \mathrm{~mm}$, bem distribuídas, com um período seco definido, de quatro a cinco meses (Coste, 1969).

Temperaturas médias anuais entre 18 e $21^{\circ} \mathrm{C}$, sem grandes variações sazonais, reflexo de sua origem em região equatorial de altitude, parecem ser os limites mais indicados para C. arabica (Alègre, 1959). Camargo et al. (1977), em trabalho de zoneamento agrícola para a cultura no Estado de São Paulo, estabeleceram a faixa de temperatura média anual entre 18 e $22^{\circ} \mathrm{C}$ como sendo apta ao seu desenvolvimento. Estudos de Franco (1956), Franco (1961), Camargo \& Salati (1966) evidenciam que várias fases biológicas têm seu desenvolvimento e/ou crescimento reduzidos e até paralisados totalmente em condições de temperaturas extremas.

Nesse sentido, em regiões onde temperaturas acima de $30^{\circ} \mathrm{C}$, por um período prolongado, são freqüentes, ocorrem danos a folhagem e se essas temperaturas elevadas ocorrerem na fase de florescimento, podem provocar abortamento dos botões florais, reduzindo seu vingamento, não produzindo frutos (Camargo, 1985a). O mesmo autor relata que em regiões com temperatura média anual que acima de $23^{\circ} \mathrm{C}$, 0 desenvolvimento e a maturação dos frutos são acelerados, acarretando perdas freqüentes na qualidade.

Também, o cafeeiro se mostra pouco tolerante ao frio. Temperatura de $-2,0^{\circ} \mathrm{C}$, próxima às folhas já provoca início de danos ao tecidos (Camargo \& Salati, 1966), enquanto que temperaturas foliares entre $-3,0$ e $-4,0^{\circ} \mathrm{C}$ provocam danos graves e morte dos tecidos (Caramori \& Manetti Filho, 1993; Sentelhas et al., 1995). Camargo (1985a) 
relata que para regiões com temperaturas médias anuais inferiores a $18^{\circ} \mathrm{C}$, a ocorrência de geadas, mesmo que esporádicas, e ventos frios podem limitar a exploração econômica da cafeicultura.

Com relação a precipitação, Alègre (1959) cita que a faixa ótima de precipitação deve situar-se entre 1.200 e $1.800 \mathrm{~mm}$, embora trabalhos indiquem que o cafeeiro cresce sob ampla faixa de precipitações (DaMatta \& Rena, 2002). Além disso, a necessidade hídrica depende de outros fatores, como a distribuição anual das chuvas e o ritmo anual da evapotranspiração, o que pode compensar a ocorrência de precipitações relativamente baixas.

Camargo (1985b), analisando dados comparativos do balanço hídrico climatológico de várias regiões produtoras do Brasil, sugere que a produção econômica do cafeeiro arábica suporta bem deficiências hídricas de até $150 \mathrm{~mm}$ anuais, principalmente quando a estação seca coincide com a maturação e a colheita. Contudo, segundo esse autor, mesmo com deficiência hídrica anual inferior a $100 \mathrm{~mm}$, porém abrangendo o período de frutificação, podem ser observadas quebras de produtividade.

\subsection{Fenologia do cafeeiro}

A fenologia pode ser definida como o estudo dos eventos periódicos da vida da planta em função da sua reação às condições do ambiente (Fancelli \& Dourado Neto, 1997). Ortolani et al (1970) relatam que no cafeeiro arábica, nas condições de cultivo da maioria das regiões do Brasil, podem ser distinguidas as fases preparativa e construtiva durante seu ciclo fenológico. No período seco, associado a baixas temperaturas, ocorre a fase preparativa, que não se manifesta claramente por caracteres externos. Durante o período quente e chuvoso predomina a fase construtiva, onde se manifestam as atividades de crescimento dos ramos, folhas, gemas, flores e frutos. Durante a fase construtiva existe uma competição entre o crescimento vegetativo e o processo de frutificação, evidenciada pelos anos alternados de grandes e pequenas produções.

A ordenação das fases fenológicas possibilita determinar as relações e o grau de influência dos fatores envolvidos. Nesse sentido, Camargo \& Camargo (2001) descreveram a sucessão das fases vegetativas e reprodutivas dos cafeeiros da espécie Coffea arabica L., nas condições climáticas tropicais do Brasil, (Figura 1), que ocorrem em aproximadamente dois anos, diferentemente da maioria das plantas que emitem as inflorescências na primavera e frutificam no mesmo ano fenológico. O ciclo fenológico, para 
as condições climáticas tropicais do Brasil, foi subdividido em seis fases distintas: (1) vegetação e formação das gemas foliares; (2) indução e maturação das gemas florais; (3) florada; (4) granação dos frutos; (5) maturação dos frutos e (6) repouso e senescência dos ramos terceários e quaternários.

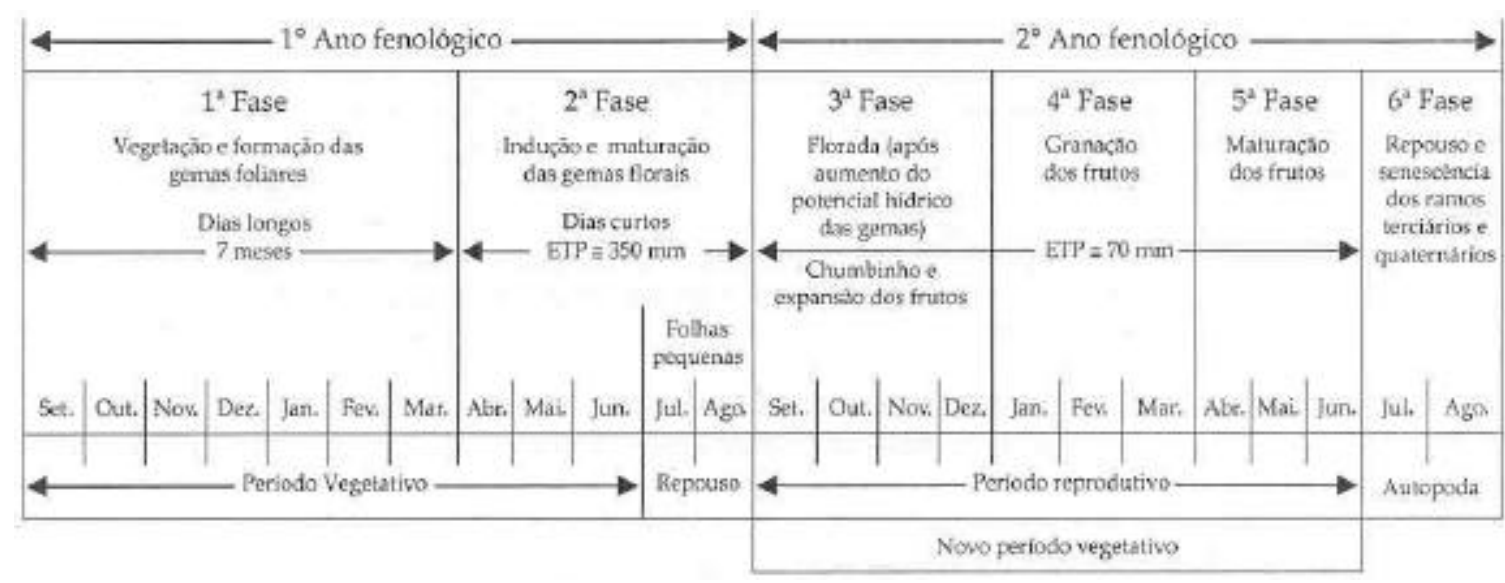

Figura 1 - Esquematização das seis fases fenológicas do cafeeiro arábica, durante 24 meses, nas condições climáticas tropicais do Brasil. (extraído de Camargo \& Camargo, 2001)

No primeiro ano fenológico são formados os ramos vegetativos, com gemas axilares nos nós, que depois são induzidas a se transformarem em gemas reprodutivas (Gouveia, 1984), sendo esse processo determinado por condições ambientais como redução do fotoperíodo (Camargo, 1985a; Camargo \& Camargo, 2001; Camayo-Velez et al., 2003). Posteriormente essas gemas florais amadurecem, entram em dormência e se tornam aptas para a antese, que ocorre, causada principalmente por chuva ou irrigação abundante (Rena \& Maestri, 1985).

Segundo Camargo \& Camargo (2001), a maturação das gemas florais ocorre quando a evapotranspiração potencial acumulada desde o mês de abril atinge os $350 \mathrm{~mm}$, o que implica, para as condições de cultivo de São Paulo, florada principal entre os meses de setembro e outubro. Os autores relatam ainda que a florada principal é bem definida quando se verifica um período de restrição hídrica durante o período de repouso das gemas, fato com que concordam Camayo-Velez et al. (2003).

O segundo ano fenológico inicia-se com a florada, seguida pela formação dos chumbinhos e expansão dos grãos, até seu tamanho normal. Havendo estiagem forte 
nessa fase, o estresse hídrico prejudicará o crescimento dos frutos, resultando em peneira baixa. Após essa fase, segue-se a granação dos frutos, em pleno verão, de janeiro a março. Estiagens severas na fase de granação poderão resultar no aparecimento de frutos chochos. A produção é finalizada com a maturação dos frutos, que ocorre a partir de abril, para as condições de cultivo do planalto paulista, onde deficiências hídricas moderadas poderão beneficiar a qualidade da bebida.

\subsection{Microclima de cultivos}

\subsubsection{Fatores que determinam o microclima}

Segundo Rosemberg (1974), microclima pode ser definido como o clima próximo à superfície, onde vivem as plantas e animais. A natureza da superfície confere características especiais ao microclima do ambiente, sendo importante o tipo e porte da vegetação, espaçamento da cultura, arquitetura foliar, cobertura do solo, entre outras.

A caracterização do microclima de uma superfície qualquer envolve o estudo do comportamento de variáveis como radiação solar, velocidade do vento, temperatura e umidade do ar, entre outras.

A radiação solar atua diretamente sobre o desenvolvimento e crescimento das plantas (Rosemberg, 1974), pois seu balanço determina a quantidade de energia para processos essenciais a planta como a fotossíntese, a evapotranspiração, além de determinar processos físicos como o aquecimento e resfriamento do ar e solo.

O balanço de radiação é composto pelo balanço de ondas curtas (BOC) e pelo balanço de ondas longas (BOL). O balanço de ondas curtas em uma superfície vegetada é definido com a radiação solar global subtraindo-se a radiação refletida. Já o balanço de ondas longas é definido como a radiação atmosférica em direção à superfície, menos a radiação emitida pela superfície.

O saldo de radiação $(\mathrm{Sr})$ é obtido pelo somatório de radiação de ondas curtas (BOC) e ondas longas (BOL), sendo que seu conhecimento é importante para explicar o comportamento espacial e temporal de outras variáveis meteorológicas (Rosemberg, 1974), determinando as condições microclimáticas de um cultivo agrícola através do balanço de energia.

O balanço de energia pode ser definido como a partição do saldo de radiação $(S R)$ em fluxo de calor sensível $(H)$, fluxo de calor latente $(\lambda E)$, fluxo de calor para o solo 
(FS), energia utilizada no processo da fotossíntese (F) e do calor armazenado nas plantas. Este balanço apresenta componentes apenas verticais, podendo ser alterado pela advecção, caracterizado por fluxos horizontais de energia. Considerando as respectivas grandezas, e desprezando o armazenamento de calor, o balanço de energia, de maneira simplificada pode ser resumido pela equação:

$$
S R=H+\lambda E+F S
$$

Nessa situação, a superfície passa ser fonte ou dreno de energia em função do comportamento do saldo de radiação. Quando o SR é positivo, durante o dia, a superfície atua como fonte, fornecendo calor sensível para as camadas mais próximas, aquecendo 0 ar, e calor latente, pelo processo da evapotranspiração, além de fornecer calor para o solo. Desse moco ocorre diminuição da temperatura e umidade em relação a altura sobre uma superfície vegetada.

Durante a noite, quando SR é negativo, a superfície atua como dreno de energia, resfriando $\mathrm{o}$ ar adjacente e o solo, alterando o comportamento dos perfis de temperatura $\mathrm{e}$ umidade em relação ao dia.

Dessa maneira, pode se dizer que o balanço de energia é que condiciona o microclima próximo a uma superfície (Rosemberg, 1974). Assim, quando a superfície é um solo desnudo ou vegetação, ocorrem mudanças na temperatura nos primeiros centímetros abaixo da superfície do solo ou acima dela ou da vegetação. As mudanças na umidade do ar com elevação da altura são mais significativas perto da superfície e o vento tende a diminuir com a aproximação da superfície.

\subsubsection{Interações microclimáticas em comunidades vegetais}

As interações que ocorrem entre a atmosfera e a superfície resultam em fluxos que alteram as propriedades físicas da atmosfera, condicionando o microclima (Sentelhas et al. 1993). Os mesmos autores relatam que as trocas dos constituintes da atmosfera entre a superfície vegetada e o ar dependem, na maioria das vezes, dos fatores ligados às condições microclimáticas, que por sua vez são condicionadas pela forma como o escoamento é obstruído ou pela densidade e disposição da cultura.

Quando a comunidade vegetal é representada por um cultivo em renque, as condições microclimáticas podem apresentar peculiaridades, devido à disposição da 
cultura no campo e a arquitetura foliar. Segundo Sentelhas et al.(1993) e ainda Brenner (1996), esse fatores vão influenciar a absorção de energia pela folhagem, interação com os ventos e como conseqüência da co-ação desses fatores, trocas gasosas e de calor com a camada de ar adjacente.

Vários estudos tem sido realizados com as interações microclimáticas em culturas. Um dos objetivos desses estudos é a estimativa de fluxos turbulentos entre a superfície vegetada e a atmosfera. Nesses casos se faz necessária a determinação da resistência aerodinâmica de uma cobertura vegetal ao transporte de calor sensível, vapor d'água e $\mathrm{CO}_{2}$, proporcional ao deslocamento do plano zero $(d)$ e ao comprimento da rugosidade $\left(z_{0}\right)$ (Penman \& Long, 1960).

Devido às dificuldades envolvidas na determinação de $d$, seu valor pode ser estimado em função da altura (Pereira et al., 1997), o que segundo esses próprios autores, pode levar a erros associados a essa simplificação, pois $d$ e $z_{0}$ são afetados pelo tipo e densidade da cobertura e velocidade do vento (Shaw \& Pereira, 1982).

A determinação dos parâmetros aerodinâmicos em cultivos agrícolas foi realizada por diversos autores, em diversas culturas, como: Jaramillo-Robledo (1975) em cafeeiro de porte baixo; Uchima (1976) em arroz; Pedro Júnior \& Magalhães (1982) em soja; Brunini et al. (1983) em milho; Sentelhas et al. (1993) em videira e Righi et al. (2003) em um cafezal recém-implantado, entre outros. Esses autores evidenciaram que os parâmetros $d$ e $z_{o}$ são afetados pela altura da cultura, densidade de cobertura e arquitetura da vegetação. Para cultivos em renques e com coberturas descontínuas, Hicks (1973), citado por Sentelhas et al. (1993) e Righi et al. (2003) constataram ainda a influência da direção do vento na determinação desses parâmetros.

\subsubsection{Método da razão de Bowen}

Estudos têm relatado que a partição do saldo de radiação nos fluxos de calor sensível e latente (Equação 1) depende das condições de suprimento hídrico da vegetação. Dessa maneira, superfícies bem supridas de água apresentam forte relação entre o saldo de radiação e o fluxo de calor latente $(\lambda E)$. Por ouro lado, em superfícies que apresentam deficiência hídrica, parte significativa do saldo de radiação pode ser convertida em calor sensível $(H)$, favorecendo o aquecimento da superfície (Villa Nova, 1973).

Um dos principais métodos micrometeorológicos para determinação dos fluxos de calor sensível e latente em cultivos é o método da razão de Bowen (Bowen, 1926). Uma 
premissa básica para o emprego desse método é considerar igual à unidade a razão entre os coeficientes de difusividade turbulenta de calor sensível e de calor latente, o que permite simplificar a determinação da razão de Bowen e os fluxos de calor latente e sensível, utilizando-se apenas medidas de perfil de temperatura de bulbo seco e de bulbo úmido (Pereira et al., 1997).

Esse método, apesar de suas limitações, tem sido largamente utilizado para determinação do balanço energético em culturas, determinando-se os fluxos de calor sensível e latente em diversas culturas (Oliver \& Sene, 1992, Prueger et al., 1998, Marin et al., 2002 e Pezzopane \& Pedro Junior, 2003), entre elas o cafeeiro (Jaramillo-Robledo \& Gomez-Gomez, 1989; Gutierrez \& Meinzer, 1994 e Marin, 2003), além da determinação do coeficiente de cultura (Malek \& Bingham, 1993, Gutierrez \& Meinzer, 1994; Marin, 2003).

\subsection{Microclima em cultivos arborizados e protegidos por quebra-ventos}

Em sistemas arborizados e policultivos, em função da natureza heterogênea de seus componentes, onde diferentes organismos compartilham o mesmo espaço, o ambiente físico afeta e interage de modo complexo, modificando as características microclimáticas e promovendo alterações no balanço de energia.

Nestes sistemas, Willey (1975), Monteith et al. (1991), Sá (1994) e Perfecto (1996) relatam que dependendo da consorciação, as interações entre as plantas componentes e a atmosfera, avaliadas em termos micrometeorológicos podem ser assim resumidas:

- interceptação de energia radiante pela folhagem, sendo este fator dominante na produção de biomassa;

- interceptação da chuva pela folhagem interferindo na disponibilidade hídrica;

- alteração no regime de vento, que além dos seus efeitos e danos mecânicos, afeta a taxa de transpiração e fluxo de gás carbônico;

- modificações na temperatura, que determina a taxa de desenvolvimento e crescimento vegetal e,

- alterações no regime de défice de pressão de vapor d'água e modificações na transpiração. 


\subsubsection{Radiação solar global}

A radiação solar no interior da comunidade vegetal é o primeiro elemento meteorológico a ser modificado com a arborização de uma cultura. A análise da radiação solar nesses sistemas de cultivo deve considerar seus diferentes componentes, classificados pelo comprimento de onda, visto existir diferentes coeficientes de absorção para cada um (Brenner, 1996). O dossel das árvores sombreadoras intercepta grande parte da radiação incidente (Vandenbeldt \& Williams, 1992), predominando sob suas copas radiação difusa. Dependendo da densidade da copa e disposição das árvores sombreadoras, diferentes quantidades e tamanhos de manchas de radiação direta atingem a cultura sombreada, o que repercutirá também na quantidade de radiação difusa.

Como a radiação na faixa do visível, radiação fotossinteticamente ativa, é muito absorvida pela cobertura vegetal, esta é a componente que sofre maior redução ao nível da cultura sombreada, o que repercute em redução do potencial produtivo. Embora, sob este ponto de vista a arborização tem efeito negativo na produtividade, excesso de radiação solar pode causar estresse térmico na cultura, o que é contornado com a proteção conseguida nos cultivos arborizados. Nesse sentido, Silva et al. (1999), em estudos de interceptação de radiação fotossinteticamente ativa em pastagens arborizadas verificaram que na projeção da copa de árvores, embora se tenha menor disponibilidade deste elemento, a produção de matéria seca é favorecida, principalmente em período seco.

Por outro lado, a radiação térmica emitida pelo sol sofre menor absorção pela cobertura vegetal e chega em maiores proporções no dossel da cultura sombreada, podendo ocorrer pouca redução da temperatura do ambiente em relação ao observado em cultivo a céu aberto.

Nas condições de cultivo de café no Brasil, a experiência tem demonstrado que em regiões tropicais, como São Paulo e Estados vizinhos, a densidade da arborização permanente deve atenuar cerca de $20 \%$ da incidência da radiação solar (Camargo, 1990). Segundo esse mesmo autor, para as condições de cultivo da região Nordeste, a arborização deve ser mais densa, permitindo uma atenuação em torno de 50\%.

Vários autores estudaram o efeito do sombreamento natural no cultivo de café no microclima da cultura, crescimento de plantas, produtividade e qualidade da bebida (Barradas \& Fanjul, 1986; Baggio et al. 1997; Miguel et al. 1995; Beer et al., 1998; Peeters et al. 2002). Nesses trabalhos, os autores descrevem o sombreamento de maneira qualitativa, quer seja pelo tipo de árvore utilizada ou pela densidade de plantio da cultura 
intercalar, porém poucos autores determinaram a quantidade de interceptação de maneira quantitativa, como é o caso dos trabalhos de Pezzopane et al. (2003a), em um sistema consorciado de café com coqueiro-anão verde e de Farfan-Valencia et al. (2003), em sistemas arborizados de café na Colômbia.

Pezzopane et al. (2003a), analisando a interceptação de radiação solar global em um consórcio de café com coqueiro anão verde, verificaram que ao longo do ano a incidência de radiação foi $42 \%$ menor no cultivo consorciado, sendo que nos meses de inverno, esta atenuação foi menor que nos meses de verão, provavelmente em função da maior inclinação do sol no período de inverno, fato com que concordam Black \& Ong (2000) e Farfan-Valencia et at. (2003), atribuindo ainda a variação na transmissividade da radiação solar relacionada a arquitetura da planta sombreadora e o arranjo espacial utilizado.

Trabalhando com um cafezal recepado consorciado com guandu (Cajanus cajan) no Paraná, Morais \& Caramori (2001) obtiveram interceptação de radiação solar global média de $87 \%$, no período de maio e junho. Apesar do valor ser considerado alto, a atenuação ocorreu em período de inverno, trazendo benefícios para a recuperação da lavoura recepada relacionados a proteção de geadas.

\subsubsection{Velocidade do vento}

Brenner (1996) relata que a introdução de árvores ou arbustos em um cultivo agrícola muda o regime de vento sobre as plantas alterando a velocidade no plano horizontal, bem como a turbulência. À medida que se obtém mudanças no regime de vento em sistemas combinados de cultivo, ocorrem alterações na condutância da camada limite, modificando os fluxos de energia e massa sobre a superfície (Rosemberg, 1974; Brenner, 1996). Além das alterações promovidas no comportamento dos fluxos energéticos, a utilização de sistemas agroflorestais como forma de cultivo agrícola, reduz efeitos danosos de ventos fortes sobre as culturas (Stigter et al., 2002).

Brenner (1996) verificou que devido a desuniformidade de cobertura e a complexidade de estrutura do dossel, não se obtém perfis verticais de vento logaritimicos em sistemas agroflorestais ou nas proximidades de quebra-vento, sendo necessário lançar mão de outras equações para expressar o escoamento. O mesmo autor apresenta resultados de perfis verticais de vento em cultivos de árvores esparsas, extraídos do trabalho de Green (1991), onde relata que a velocidade normalizada de vento, isto é, a 
relação entre a velocidade em determinada altura $(\mu)$ e a velocidade no topo da cultura $(\mu 0)$ aumentada com a diminuição da densidade das árvores, sendo esse comportamento mais característico até o topo da cultura.

Beer (1987), além de Camargo \& Pereira (1994) relatam que para culturas como o cafeeiro a redução da velocidade do vento promovida pela utilização de arborização é um dos efeitos mais benéficos desta prática.

Os efeitos do vento em cafeeiros, segundo Camargo (1985a) e Camargo \& Pereira (1994), podem ser diretos, simplesmente mecânico, quando acarretam danos às folhas e gemas, além de potencializar a queda de flores e frutos em desenvolvimento, ou indiretos, como os ecofisiológicos, provocando aumento da demanda hídrica ou facilitando a penetração de microorganismos. Ventos frios, quando são fortes e persistentes, podem intensificar o fenômeno conhecido como geada de advecção

Caramori et al. (1986) observaram danos mecânicos severos sobre mudas de café arábica, cvs. Mundo Novo e Catuaí, em plantas submetidas a $3 \mathrm{~m} \cdot \mathrm{s}^{-1}$, sendo que a partir de $2 \mathrm{~m} . \mathrm{s}^{-1}$ também houve menores incrementos de altura e comprimento de internódios. Gutiérrez et al. (1994), trabalhando com plantas adultas de café, no campo, sugerem que ventos moderados, ao redor de $2,5 \mathrm{~m} \cdot \mathrm{s}^{-1}$ provocariam aumentos do défice de saturação, como conseqüência, reduzindo a transpiração em conseqüência do fechamento estomático.

\subsubsection{Temperatura do ar e de folhas}

O comportamento da temperatura do ar e da umidade relativa em cultivos arborizados ou em cultivos protegidos por quebra-vento vai depender do tipo de cobertura e densidade de sombreamento. De modo geral, pode se dizer que, existindo menor disponibilidade de energia sob o dossel das árvores sombreadoras, a temperatura do ar, durante o período diurno, tende a ser menor do que em cultivo aberto. Em sistemas agroflorestais a variação espacial tende a ser menor, se a cobertura for mais homogênea (Brenner, 1996).

Nesse ponto é interessante observar diferenças entre os cultivos arborizados, na presença de árvores sombreadoras, e em cultivos protegidos por quebra-ventos. Nesses últimos a temperatura durante o período diurno tende a ser maior do que em cultivos abertos. Isso acontece, segundo Rosemberg (1974), pois à medida que se verifica redução na movimentação atmosférica devido a menor incidência de vento, ocorrem alterações no 
balanço de energia, diminuindo-se os gradientes entre as camadas sobre as plantas ou solo e por conseqüência a evaporação, sendo destinada maior parte do saldo de radiação ao fluxo de calor sensível, em comparação ao cultivo aberto.

Outros autores também obtiveram temperaturas diurnas superiores em cultivos protegidos com quebra-ventos, quando a incidência de radiação solar é semelhante a cultivos não protegidos (Brown \& Rosemberg, 1972; Ujah \& Adeoye,1984), ambos em cultivos protegidos por quebra-ventos artificiais.

Ainda com relação a influência da interceptação da radiação solar e mudanças no regime de vento no comportamento da temperatura no período diurno em cultivos consorciados, é importante relacionar os trabalhos de Monteith et al. (1991) e Corlett et al (1992), em estudos com consórcio de leucena (Leucaena leucocephala) e milheto (Pennisetum glaucum) na Índia. No início do cultivo, quando a interceptação de radiação não foi significativa, o cultivo protegido apresentou maiores valores de temperatura do ar em comparação ao cultivo aberto, fato que se reverteu do meio para o final do ciclo devido à maior interceptação de radiação solar.

Vários autores observaram o comportamento da temperatura do ar e de folhas em diversos tipos de cultivos de cafezais arborizados nas diferentes regiões produtoras do Brasil e em outros países.

Analisando a variação da temperatura do ar, em seus valores máximos e mínimos, durante o ano, em um sistema agroflorestal de produção de café no México, Barradas \& Fanjul (1986) verificaram que as temperaturas máximas no cultivo a pleno sol sempre foram maiores, $5,4^{\circ} \mathrm{C}$ em média durante $\mathrm{o}$ ano. Quando são analisados os valores mensais de temperatura mínima, o panorama se inverte, com valores maiores para o cultivo protegido, na ordem de $1,9^{\circ} \mathrm{C}$, durante os meses com temperaturas mais baixas.

Miguel et al. (1995), obtiveram em um plantio de cafeeiros arborizados com grevílea, em Varginha, MG, com 4 anos de implantação, média anual da temperatura máxima do ar de $32,4^{\circ} \mathrm{C}$, contra $33,2^{\circ} \mathrm{C}$ do cultivo a pleno sol. As médias das temperaturas mínimas do ar foram de 13,9 e $13,2^{\circ} \mathrm{C}$, com valores superiores ao cultivo arborizado. Quando o cultivo estava com 14 anos de implantação, os autores obtiveram média anual da temperatura máxima do ar de $29,0^{\circ} \mathrm{C}$, contra $33,3^{\circ} \mathrm{C}$ do cultivo a pleno sol. As médias das temperaturas mínimas do ar foram de 14,7 e 13,6드. com valores superiores ao cultivo arborizado. A redução na temperatura média anual, promovida pelo sistema arborizado, foi de 1,0 para $1,6^{\circ} \mathrm{C}$ entre os dois períodos de medidas. 
Em um cafezal consorciado com coqueiro-anão, na região de Garça, SP, Pezzopane et al. (2003a), analisando a temperatura do ar em dois pontos do sistema, sendo um mais protegido pelas folhas do coqueiro e outro mais exposto, obtiveram diferença nas médias das temperatura máxima e mínima do ar de $1,5^{\circ}$ e $0,3^{\circ} \mathrm{C}$, respectivamente.

Os resultados de Miguel et al. (1995) e Pezzopane et al. (2003a), bem como o de Barradas \& Fanjul (1986), evidenciam que a variabilidade temporal e espacial da temperatura em um sistema consorciado e suas diferenças em relação a um cultivo a pleno sol vão depender do tipo de copa da árvore utilizada e da densidade do sombreamento.

O efeito sobre a temperatura mínima do ar em cultivos arborizado e conseqüente proteção contra geadas também é relatado por diversos autores.

Caramori et al. (1996), em estudos realizados com arborização de cafezais com bracatinga (Mimosa scrabella), verificaram que a temperatura mínima do ar e de folhas do cafeeiro em noites de geada de radiação foi significativamente superior aos valores obtidos no cultivo a pleno sol ( 2 a $4^{\circ} \mathrm{C}$, respectivamente). Segundo estes autores e ainda Brenner (1996) e Caramori et al. (1997), isto ocorre porque a árvore de sombra emite radiação de onda longa para a cultura em quantidades semelhantes a que a cultura emite para o céu, provocando uma menor perda de radiação em noites de geada. Menores perdas radiativas em cultivos arborizados em noites de resfriamento intenso também foram obtidos por Morais \& Caramori (2001) e por Pezzopane et al. (2003a).

Pezzopane et at. (2003a), analisando valores de temperatura mínima do ar em um consórcio de café com coqueiro anão verde em comparação ao monocultivo, durante os meses de inverno, verificaram que no cultivo consorciado os valores foram maiores e esta diferença aumenta conforme os valores se tornam mais baixos, atingindo até $1,2^{\circ} \mathrm{C}$.

Em cafeeiros recém-implantados ou recepados, é importante ressaltar a contribuição dos trabalhos realizados no norte Paraná por Caramori et al. (1999), Caramori et al. (2000) e Morais \& Caramori (2001) sobre o estudo das temperaturas mínimas em noites de geada, em cultivos com arborização temporária.

Os autores testaram várias espécies de hábito anual ou semi-perenes, obtendo os melhores resultados de proteção contra geadas com o guandu (Cajanus cajan). Em diversos episódios, a temperatura mínima do ar monitorada nos cultivo arborizado temporariamente com o guandu foi superior em 0,5 a $4,0^{\circ} \mathrm{C}$, em comparação ao cultivo não 
protegido. Os autores atribuíram essa variação à diferenças na intensidade das geadas e ao porte do guandu, que deverá ser implantado no inicio do verão. Quando analisada a temperatura das folhas mais expostas dos cafeeiros, a diferença atingiu $5,5^{\circ} \mathrm{C}$, com valores maiores no cultivo protegido.

Devido a maiores valores de temperatura mínima em noites de geadas de radiação, é verificado um menor dano na cultura protegida. Baggio et al. (1997), em estudos de cultivo consorciado de café com grevílea, verificaram que houve um menor dano as folhas de café conforme aumentava a população de árvores de sombra, fato semelhante ao observado por Caramori et al. (1996), em um cultivo de café arborizado com bracatinga.

Os mesmos autores constataram proteção efetiva contra geadas fracas e moderadas a uma distância de até 6 metros do tronco das árvores de bracatinga. No caso de grevílea com porte adulto, a proteção efetiva contra geadas moderadas pode chegar a até 8 metros do tronco e a 4 metros quando se tratar de geadas severas (Miguel et al., 1995; Caramori et al, 2001).

Quando se trata de culturas de menor porte a proteção pode não ser efetiva, quando as plantas não cobrem totalmente o terreno. Caramori \& Morais (1999) em sistemas com arborização temporária de cafezais com nabo, aveia e tremoço, observaram efeito contrário, com maior resfriamento nos tratamentos protegidos em comparação à testemunha, sem proteção, quando essas plantas, devido ao baixo crescimento provocado pela seca não cobriram totalmente os cafeeiros.

\subsubsection{Umidade relativa do ar}

No caso da umidade do ar, existe uma tendência de ocorrência de aumento na umidade nos cultivo arborizados ou protegidos por quebra-ventos. Entretanto, em situações específicas, como as observadas nos trabalhos de Monteith et al. (1991), onde a temperatura em cultivos protegidos é maior do que em cultivos abertos e sendo a umidade relativa do ar e défice de saturação funções dessa, as diferenças podem ser pequenas ou inexistentes. Outro fator que influencia esse elemento, segundo Brenner (1996), provocando uma variação sazonal no seu comportamento, é o tipo de vegetação e teor de umidade do solo entre os renques de quebra-vento ou entre as árvores esparsas.

Apesar das vantagens em termos microclimáticos, como as descritas acima, em termos de atenuação de excesso de radiação, diminuição da incidência de ventos e da 
manutenção da umidade do ar, alguns autores (Ong et al. 1991; Monteith et al., 1991) descrevem que essas vantagens são relativamente menos importantes quando comparadas com os efeitos adversos provocados pelos sistemas agroflorestais, como maior interceptação de chuva e competição por água e nutrientes do solo, principalmente em regiões semi-áridas e uso de cultivos anuais nos consórcios.

Barradas \& Fanjul (1986), na caracterização de sistemas agroflorestais de produção de café no México, obtiveram menores valores, durante todo o ano, de défice de pressão de vapor neste sistema em relação ao cultivo a pleno sol, em medidas realizadas as 9:00 e 15:00 horas. Sendo a pressão de saturação de vapor e por conseqüência, o défice de vapor, uma função da temperatura, os autores atribuíram esses resultados aos menores valores de temperatura no período diurno, resultado da interceptação de cerca de $85 \%$ da radiação incidente sobre os cafeeiros arborizados.

Segundo DaMatta \& Rena (2002), os estômatos do cafeeiro são altamente sensíveis à redução da umidade relativa. Nesse sentido, segundo esses autores, aumento da umidade relativa, o que geralmente ocorre em sistemas arborizados de produção de café, parece concorrer para a maximização da eficiência do uso de água (taxa de fotossíntese por unidade de água transpirada), via manutenção da abertura estomática, permitindo assim, um influxo adequado de $\mathrm{CO}_{2}$ à fotossíntese, sem, contudo, haver perda substancial de água, via transpiração.

\subsection{Arborização de cafezais}

Sistema agroflorestal, segundo Nair (1989), pode ser definido como um sistema de uso de terra que envolve a permanência deliberada, introdução ou retenção de árvores ou outras culturas arbóreas de hábito perenes ou semi-perenes em associação com culturas agrícolas ou animais com benefício mútuo resultante das interações ecológicas e econômicas. Para a cultura do café existem diversos tipos de exploração econômica em sistemas agroflorestais, sendo os mais comuns os denominados cultivos arborizados e os cultivos protegidos por quebra-ventos.

No caso da arborização, o termo tem sido empregado quando se realiza o sombreamento ralo dos cafezais, que abrange cobertura de 1/6 a 1/3 (Camargo, 1985a) ou de 1/4 a 1/8 da superfície do terreno (Fernandes, 1986), visando reduzir adversidades climáticas, problemas nutricionais e erosão do solo. 
A utilização da técnica da arborização para a produção de café é uma tecnologia aplicada em vários países da América Latina, como México, El Salvador e Costa Rica (Barradas \& Fanjul, 1986, Beer, 1987, Schaller et. al., 2003), onde existem diversas tipos de cultivos arborizados, podendo ser citados sistemas mais rústicos e tradicionais, onde se utilizam diversas espécies sombreadoras simultaneamente (Gobbi, 2000; Peeters et al., 2002; Villavivencio-Enriquez, 2003), bem como sistemas mais modernos, onde se utiliza somente uma ou mais espécies sombreadoras, de maneira mais tecnificada (Gobbi, 2000; Soto-Pinto et al., 2000; Romero-Alvarado et al., 2002).

Nesses países, a utilização da arborização visa manutenção da biodiversidade, quando realizada em cultivos tradicionais ou aumento da sustentabilidade dos cultivos de café, procurando-se reduzir os problemas de degradação dos solos quando se trata de regiões com altos índices pluviométricos, além de proporcionar aumento de renda aos agricultores com a exploração de outras essências. Outra característica da utilização desse sistemas de produção nessas regiões é a baixa adoção de insumos e defensivos agrícolas ou outros pacotes tecnológicos, como altas densidades de plantio das lavouras.

No Brasil, ao se considerar a prática da arborização de cafezais, há que se analisar separadamente a cafeicultura praticada na Região Nordeste e a do Centro-Sul do País (Fernandes, 1986). No Nordeste, em cultivos tradicionais, até a década de 80 , a arborização foi prática tradicional e muito utilizada (Matiello et al., 1989), favorecendo o desenvolvimento vegetativo e a produtividade em longo prazo. Na região de cultivo do Centro-Sul do Brasil, os estudos iniciais de sombreamento de cafezais (Franco \& Inforzato, 1951; Carvalho et al., 1961), realizados com consórcios de produção de café com com ingazeiros (Inga edulis, Inga Leptoloba) e tipuana (Tipuana tipo) desestimularam o uso desta técnica. Os autores associaram esse insucesso a fatores como a concorrência em água pelas plantas, a baixa retenção da água dos solos onde se estudou a técnica e a utilização de árvores frondosas nos consórcios, que levaria a uma rápida queda no teor da água do solo, agravando o problema em períodos com seca. Além disso, em elevados níveis de sombra ocorreu maior diferenciação de gemas vegetativas em relação às gemas florais, provocando um decréscimo na produtividade dos sistemas sombreados.

Posteriormente, nas décadas de 70 e 80, a utilização de outras espécies e níveis de sombreamento proporcionaram a reutilização dessa técnica, agora denominada arborização em algumas regiões do Brasil. Na Região Centro-sul, embora haja predomínio 
do cultivo de café a pleno sol, a utilização do cultivo arborizado tem aumentado (Baggio et al. 1997).

Situações como as discutidas acima mostram que a arborização no Brasil ainda é uma técnica controversa, sendo que sua utilização pode variar de acordo com condições ecológicas, tradição local e o nível de manejo da lavoura (DaMatta \& Rena, 2002).

\subsubsection{Arborização e manejo da cultura do café}

Quando se utiliza a prática da arborização algumas modificações irão ocorrer com relação ao manejo da cultura em comparação ao cultivo a pleno sol. Essas modificações podem ser vantajosas em alguns casos ou desvantajosas em outros dependendo do tipo de consórcio formado e da região onde ele será implantado.

As principais vantagens estão relacionadas aos aspectos climáticos e edáficos. Com relação aos aspectos climáticos, podem ser citados a amenização do microclima na lavoura, com atenuação dos excessos de vento, radiação solar e temperatura do ar, além da redução de impactos de geadas de radiação (Beer et al., 1998; Camargo \& Pereira; 1994; Caramori et al., 1996).

$\mathrm{Na}$ medida em que ocorrem alterações no microclima da lavoura, os cultivos consorciados parecem promover menores perdas de água pela transpiração excessiva, melhorando a economia hídrica. Segundo Sá (1994), os sistemas agroflorestais proporcionam grande melhoria no uso de água no solo, principalmente em regiões com disponibilidade sazonal.

Nesse sentido, existem ainda constatações sobre redução de evapotranspiração em cultivos de cafezais arborizados em comparação a cultivos a pleno sol, como apresentado nos trabalhos de Jimenez \& Golberg (1982) e Bastias et al. (1999), ambos citados por DaMatta \& Rena (2002). Outros autores, como Miguel et al. (1995) e Matsumoto et al. (2000) em trabalhos realizados com cafezais arborizados com grevílea em Varginha-MG e sudoeste da Bahia, respectivamente, verificaram o aumento da disponibilidade hídrica nas camadas superficiais do solo, após longos períodos secos, fato também constatado em outros países, como sugerem Gopal et al. (1970), em revisão sobre sistemas de produção de café sob arborização na Índia.

As vantagens relativas aos aspectos edáficos, são relatadas pela melhoria da fertilidade, além da estabilidade da temperatura do solo, ocorrendo menor perda por 
volatilização do nitrogênio e aumento da conservação do solo, com maior reciclagem de nutrientes e diminuição de processos erosivos (Beer, 1987; Schaller et al., 2003).

Beer (1987) e DaMatta \& Rena (2002) citam ainda vantagens relacionadas aos aspectos endógenos, como a atenuação do ciclo bienal da produção, diminuindo o estímulo a superprodução, reduzindo o depauperamento e tornando a lavoura mais sustentável. Ainda em relação ao aspecto endógeno, Beer (1987) além de Camargo \& Pereira (1994) destacam melhoria na qualidade de bebida, fato com que não concordam DaMatta \& Rena (2002), relatando que embora ocorra produção de frutos de maior tamanho, no cultivo arborizado não há reflexos na qualidade da bebida. Camargo e Pereira (1994) relatam ainda que o uso de arborização do cafezal, com conseqüente atenuação da radiação incidente, proporciona maior período de grãos maduros, permitindo mais tempo para colheita seletiva.

Com relação aos aspectos bióticos, a arborização poderá reduzir a incidência de pragas e doenças do cafeeiro, como verificado por Matiello \& Almeida (2001) e Caramori et al. (2001) com menor incidência de ataque de bicho mineiro em cultivos de cafezais arborizados com grevílea e seringueira, respectivamente, e Matiello et al (2001) com menor ocorrência de Phoma spp. em cultivo de café arborizado com banana em Minas Gerais. Nesses dois casos, a menor ocorrência de pragas e doenças foram atribuídas às mudanças microclimáticas ocorridas nos cultivos consorciados.

As desvantagens da arborização estão associadas ao uso de espécies inadequadas, levando a uma concorrência em água e nutrientes com o cafeeiro e ao sombreamento excessivo (Beer, 1987; Neves et al., 2001). Caramori et al. (2001) também verificaram competição por água em cultivos de café consorciado com leucena (Leucena leucochephala) e aveia (Avena strigosa) no norte do Paraná.

Em determinados cultivos arborizados também poderão ocorrer dificuldades operacionais, como a limitação de colheita mecanizada e podas freqüentes para a arborização não se tornar excessiva, como verificado por Caramori et al. (1996) em cultivo de cafezais arborizados com bracatinga (Mimosa scabrella). Ainda em relação ao manejo da cultura é preciso ressaltar que a arborização, em alguns casos, pode dificultar atividades de mecanização agrícola na lavoura, conforme constatado por Carneiro Filho \& Camargo (1987). 
Outra desvantagem do cultivo arborizado esta relacionada a maior incidência da broca do café (Hypothenemus hampel) e da ferrugem do cafeeiro (Hemilea vastratix) (Carneiro Filho \& Camargo, 1987; Caramori et al., 2001; DaMatta \& Rena, 2002).

Para Fernandes (1986) e Camargo \& Pereira (1994), a espécie utilizada na arborização permanente de cafeeiros deve possuir, como características básicas: tronco alto, com copa concentrada no topo; ser flexível ao vento; possuir rápido crescimento inicial; sistema radicular profundo, para não competir com o cafeeiro e tolerar a presença de espécies de sub-bosque, como o cafeeiro, dentre outras.

Dentre as plantas que estão sendo utilizadas no Brasil para arborização de cafeeiros, a grevílea (Grevillea robusta) e a seringueira são as espécies que apresentam características mais favoráveis para sua utilização (Matiello \& almeida, 1991; Baggio et al., 1997; Pereira et al. 1998; Macedo et al., 2001).

Além das espécies citadas acima, o uso de espécies frutíferas com alto valor de mercado e boas características para arborização, como o coqueiro-anão, a pupunha e a bananeira, com porte arbustivo podem ser boas opções (Camargo \& Santinato, 1989; Caramori \& Manetti, 1993; Matiello et al., 2001). Nesse caso a técnica apresenta mais uma de suas vantagens que é o aumento de renda para o produtor com os ganhos adicionais da espécie usada para a arborização.

Outro tipo de arborização é a consorciação temporária de cafeeiros recém implantados ou recepados com espécies intercalares, de hábito anual ou semi-perene, como o guandu (Cajanus cajan) e o tremoço (Lupinus spp.) visando proteção contra geadas e bom desenvolvimento inicial dos cafeeiros (Caramori et al., 2001; Morais \& Caramori, 2001).

\subsubsection{Arborização e produtividade do cafeeiro}

O efeito da arborização na produtividade do café depende das condições climáticas da região de cultivo, utilização de insumos e dos efeitos favoráveis e desfavoráveis que a espécie de sombra poderá trazer para a cultura sombreada. Nesse sentido, existem diversos trabalhos realizados em diferentes regiões produtoras do mundo, que demostram existir aumento, decréscimo ou igualdade de produção com a utilização da arborização.

Em condições climáticas favoráveis para o cultivo de café e com a utilização intensiva de insumos, como irrigação, adubação e defensivos agrícolas, plantios de café a 
pleno sol, de uma maneira geral, produzem mais que cultivos arborizados. DaMatta \& Rena (2002), assim como DaMatta (2004), em ampla revisão sobre o assunto, descrevem pelo menos três razões que podem reduzir a produção dos cafeeiros à medida que se aumenta o grau de arborização: menor assimilação de carbono pela planta inteira, maior estímulo à emissão de gemas vegetativas em detrimento das gemas florais e redução do número de nós produzidos por ramo.

Ainda sobre esse assunto, Cannell (1976) relata que cafezais sombreados tendem a produzir menos que cafezais a pleno sol, devido à menor emissão de nós, fator preponderante relacionado à produção da cultura. Segundo esse mesmo autor, esse fato faz com que se reduzam as possibilidades de ocorrência de produções elevadas e como conseqüência a ocorrência de ciclos bienais.

Muschler (1997) e Beer et al. (1998) determinam três fatores que precisam ser levados em consideração na adoção da prática de arborização pelos agricultores: objetivo da produção, características ambientais da região e nível dos insumos disponíveis para a produção. Diante dessa abordagem pode se dizer que quanto mais marginal for a região para a cafeicultura, característica de área com baixas altitudes, solos pobres ou com baixa fertilidade, maiores benefícios serão obtidos com o uso da arborização (Camargo, 1990; Matiello et al., 2002).

Nesse contexto, trabalhando nas condições de clima equatorial, numa área com seca de verão acentuada no Nordeste do Brasil, estado de Pernambuco, Matiello et al. (1989), realizaram um experimento de diferentes densidades de sombreamento de cafeeiros $(0,25,50,75$ e 100\%) predominantemente com cajueiros. Após sete anos de observações, verificaram que níveis de sombra entre 50 e $75 \%$ mostraram os melhores resultados, em relação ao aspecto das plantas e produção, com aumento de $170 \%$ em relação ao cultivo a pleno sol.

Dantas et al. (1990), em um experimento também conduzido em Pernambuco, em uma área sujeita à secas prolongadas, verificaram, com base em seis anos de produção de café um acréscimo de $85 \%$ na produção de café sombreado com grevílea (espaçamento 8x8m, com 156 árvores/ha) em relação ao cultivo a pleno sol. Já para um cultivo com densidade de grevíleas de 39 plantas/ha, o acréscimo foi de apenas $5 \%$ em relação ao monocultivo.

Matiello \& Almeida (1991), trabalhando em diferentes sistemas de combinação de café (Acaiá 474/19) com seringueira (clone RIMM 600), no sul de Minas Gerais, 
concluíram, após seis safras de café, que o desenvolvimento e produção de café em cultivos consorciados foram semelhantes e até superiores em relação a produção da cultura a pleno sol, durante as quatro primeiras safras de cultivo. Nas duas safras subsequentes, houve uma pequena queda de produção apenas nos tratamentos com maior densidade de seringueira, devido a concorrência entre as árvores.

Em estudos de sistema de produção de café consorciado com grevílea, em diferentes densidades de árvores de sombra (26, 34, 48, 71 e 119/ha) no norte do Paraná, Baggio et al. (1997) verificaram que, após dez anos de condução de lavoura, os stands de cafeeiros sombreados com 26, 34, 48 e 71 árvores de grevílea/ha não provocaram redução na produtividade do café em relação a testemunha, não arborizada, sendo que as combinações com 34, 48 e 71 árvores de grevílea/ha foram as economicamente mais viáveis, em função da combinação produtividade, renda extra para o cafeicultor e proteção à geada.

Os resultados dos trabalhos de Matiello et al. (1989) e Dantas et. al. (1990), além de Matiello \& Fernandes (1989), para o Estado de Pernambuco, assim como o trabalho de Batistela Sobrinho et. al. (1987) e as indicações de Camargo (1990), demonstram os benefícios de cultivos consorciados para a produção de café, especialmente em regiões quentes e secas, ambientes considerados marginais à cultura, com solos pobres, sujeitas a estresses microclimáticos e ventos fortes. Nesses casos a técnica da arborização poderá reduzir as adversidades climáticas permitindo maior sustentabilidade da cafeicultura nessas regiões.

Em áreas com clima mais adequado para o cultivo do café arábica, como o sul de Minas Gerais, a região da Mogiana, no Estado de São Paulo e no norte do Paraná, a arborização trará menores benefícios ao cafeeiro em termos de produção, ou mesmo poderá ser prejudicial, devido a concorrência que se estabelece entre o cafeeiro e a árvore utilizada (Carneiro Filho \& Camargo, 1987; Neves et al., 2001). Contudo, nessas condições ressalta-se contudo que a arborização poderá ser uma eficiente técnica de reduzir os efeitos das geadas (Caramori et al., 1996; Baggio et al., 1997).

Beer et al. (1998) relatam ainda que uma vantagem, em termos de produção, de cultivo de cafeeiros a pleno sol sobre os cultivos arborizados poderia ser limitada, principalmente em regiões tropicais, a uma ou duas décadas de ciclos produtivos. Após isso, a degradação ambiental, proporcionada por erosão do solo e resíduos de fertilizantes e pesticidas poderia reduzir a produtividade e/ou a qualidade do ambiente. 


\section{MATERIAL E MÉTODOS}

\subsection{Caracterização da área experimental}

O presente estudo foi realizado durante os anos de 2001 a 2004, no Polo Regional de Desenvolvimento Tecnológico dos Agronegócios do Nordeste Paulista, da Agência Paulista de Tecnologia dos Agronégocios, situado no município de Mococa, SP, nas seguintes coordenadas geográficas: $21^{\circ} 28^{\prime}$ de latitude Sul; a 470ㅜ'de longitude Oeste e altitude de $662 \mathrm{~m}$.

De acordo a classificação de Köppen, o clima da região de Mococa é classificado como Cwa (Russo Júnior, 1981), apresentando inverno seco e verão chuvoso. De acordo com as normais do Centro de Pesquisa e Desenvolvimento de Ecofisiologia e Biofísica do Instituto Agronômico de Campinas, as temperaturas médias mensais variam de $23,6^{\circ} \mathrm{C}$ no verão a $18,5^{\circ} \mathrm{C}$ no inverno, sendo a média anual de $21,8^{\circ} \mathrm{C}$. A precipitação anual é da ordem de $1.498 \mathrm{~mm}$, apresentando uma estação chuvosa, de outubro a março, com cerca de $1.205 \mathrm{~mm}$ de chuva e a estação seca, de abril a setembro, cerca de $293 \mathrm{~mm}$ de chuva (Figura 2A). Na Figura 2B é apresentado o extrato do balanço hídrico normal de acordo com Camargo \& Camargo (1993), evidenciando os períodos de deficiência e de excedente hídrico. Em termos médios, o excedente hídrico total ao longo do ano é de $484 \mathrm{~mm}$ e a deficiência hídrica é de $53 \mathrm{~mm}$.

A área experimental, em solo classificado como Argissolo Vermelho (Embrapa, 1999) de acordo com os levantamentos de Torrado (1989), é constituída de cafeeiros cultivados em consórcio, implantados no mês de outubro de 1999, na seguinte característica: a cultivar de café plantada é a Icatu Vermelho IAC 4045, enxertado sobre cv. Apoatã IAC 2258, com espaçamento de 4 metros entre linha e $1 \mathrm{~m}$ entre plantas, totalizando 2500 plantas.ha ${ }^{-1}$, consorciado com banana 'Prata Anã' (Musa AAB), com espaçamento de $8 \times 8$ metros, totalizando 156 plantas.ha $^{-1}$, instaladas em parcelas experimentais possuindo $40 \times 40$ metros, sendo utilizadas como bordadura as linhas 
marginais. A área experimental possui ainda parcelas de café cultivadas a pleno sol, plantadas com a mesma cultivar e sob as mesmas condições de espaçamento, que foram utilizadas na comparação dos sistemas de plantio. O delineamento utilizado foi o de blocos ao acaso, com quatro repetições.

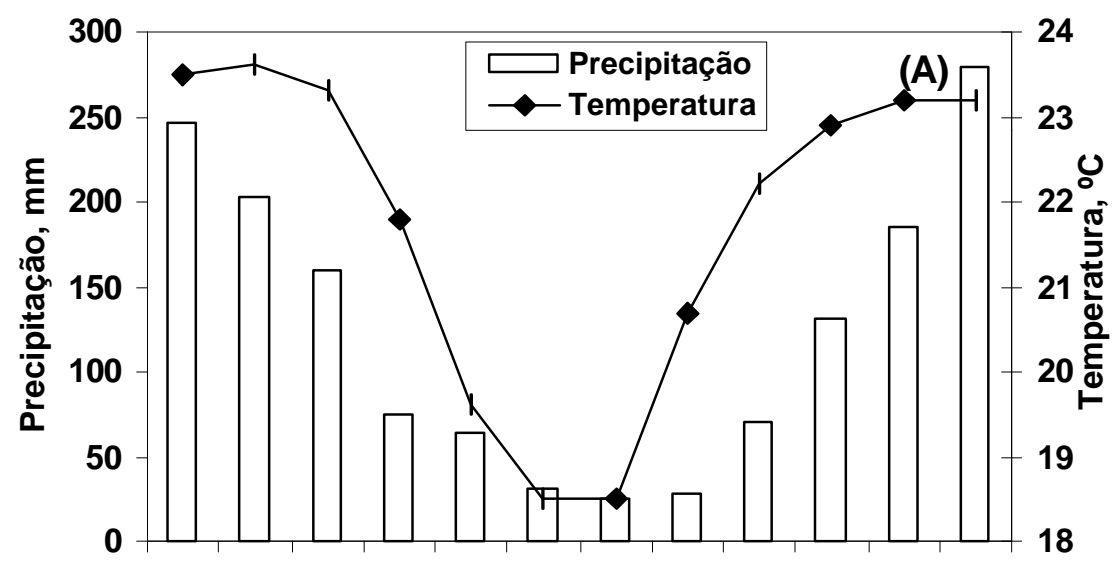

Jan Fev Mar Abr Mai Jun Jul Ago Set Out Nov Dez

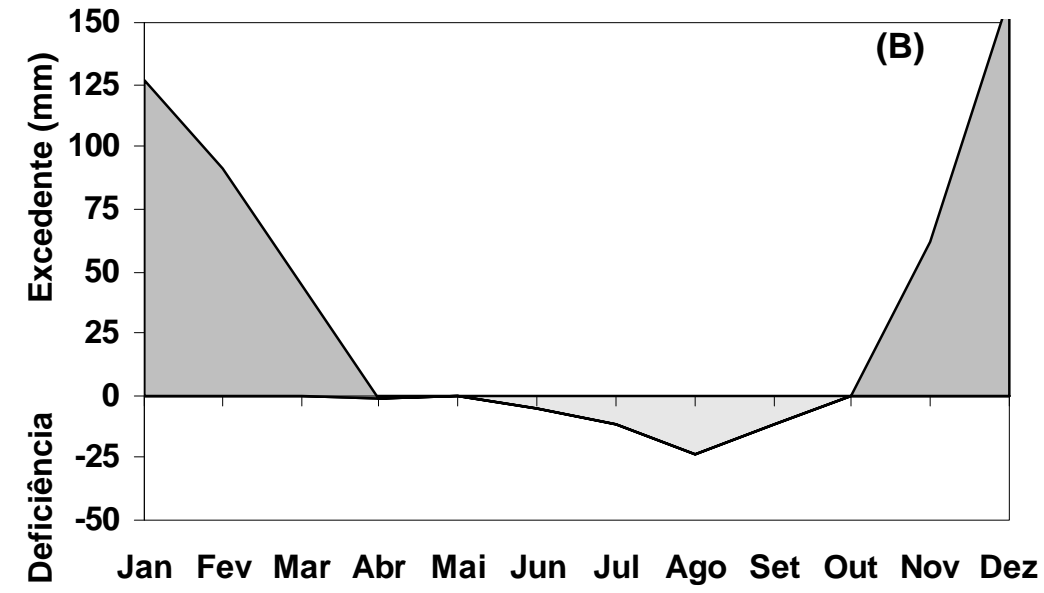

Figura 2 - Valores mensais de precipitação pluvial e temperatura do ar (A) e extrato do balanço hídrico climatológico (B) de Mococa, SP, a partir de dados normais do período de 1961-1990 e considerando CAD de $100 \mathrm{~mm}$

As parcelas se encontravam situadas lado a lado, em encosta com orientação nordeste, com ligeira declividade. A disposição geométrica das plantas constitui um sistema de renques de cafeeiros com direção de aproximadamente 70 graus a partir do norte para o oeste. Na Figura 3 é apresentada uma representação esquemática, e na Figura 4 ilustrações das parcelas de sistema de monocultivo e de consorciação de café com banana 'Prata Anã' utilizadas no presente trabalho. 
(A)

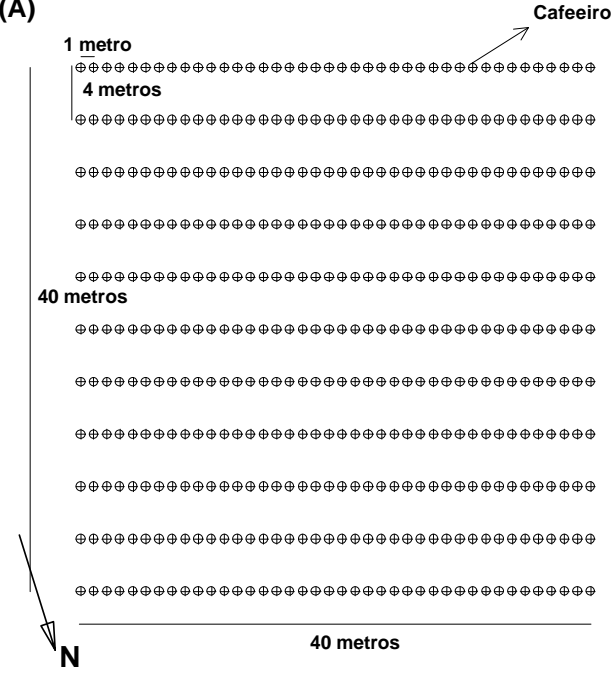

(B)

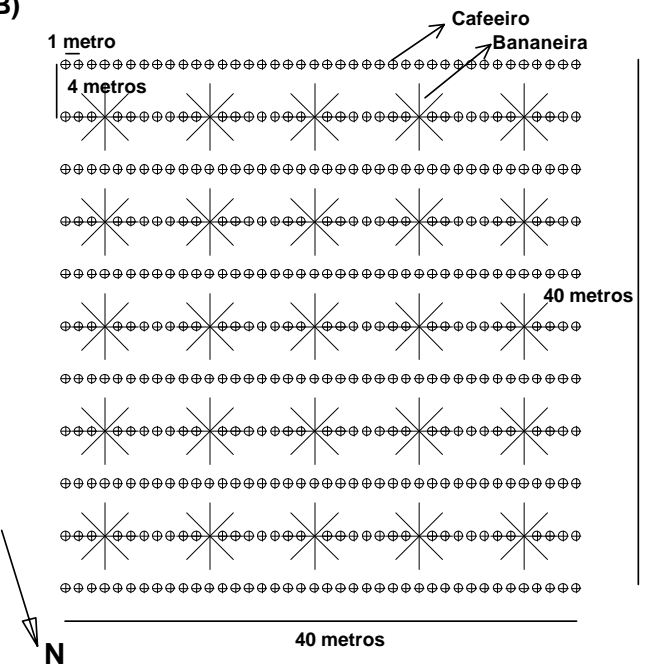

Figura 3 - Representação esquemática das parcelas experimentais de cultivo de café em sistema de monocultivo (A) e consorciado com banana 'Prata Anã' (B)

(A)
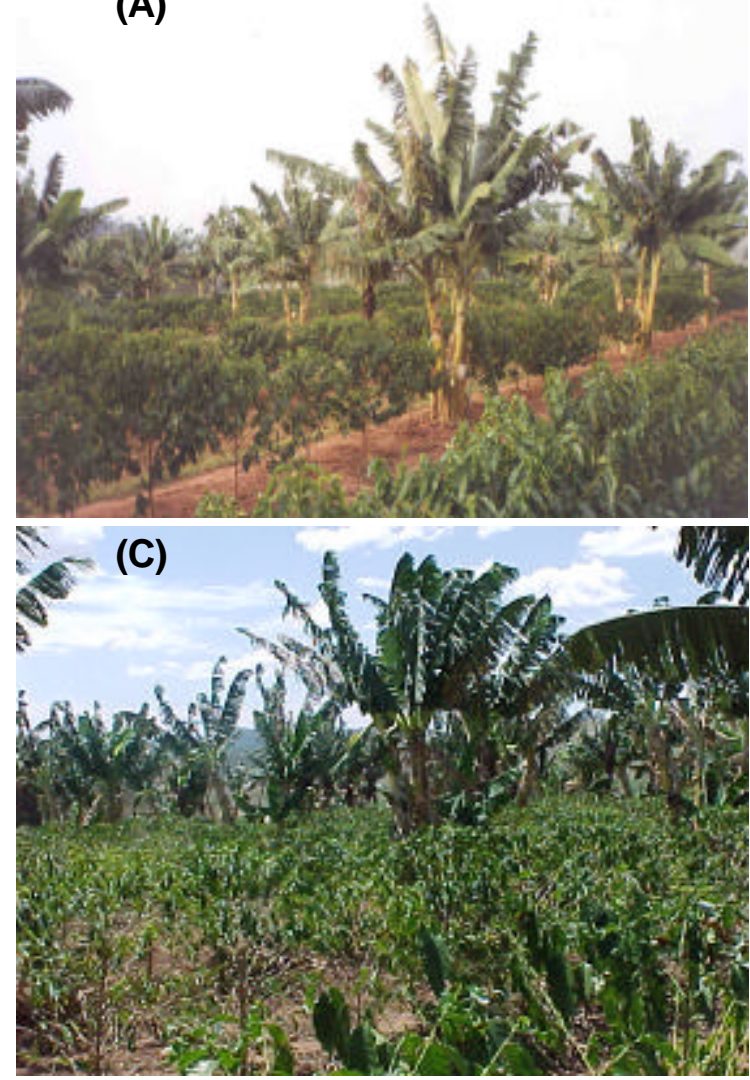

(B)

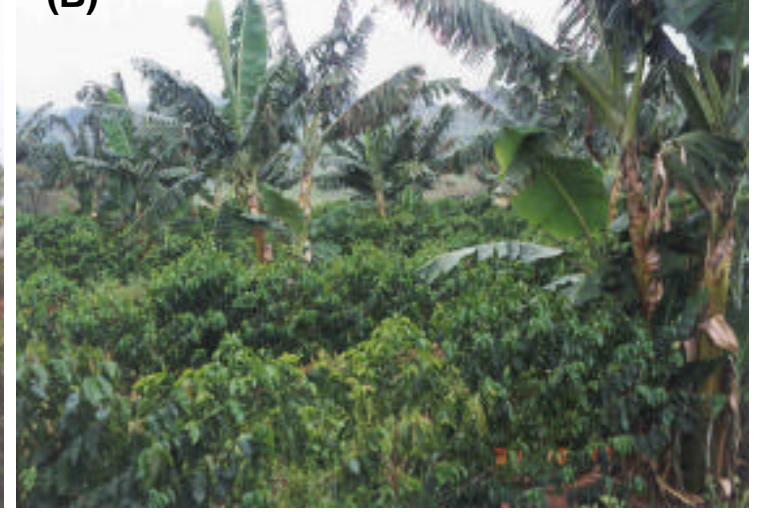

(D)

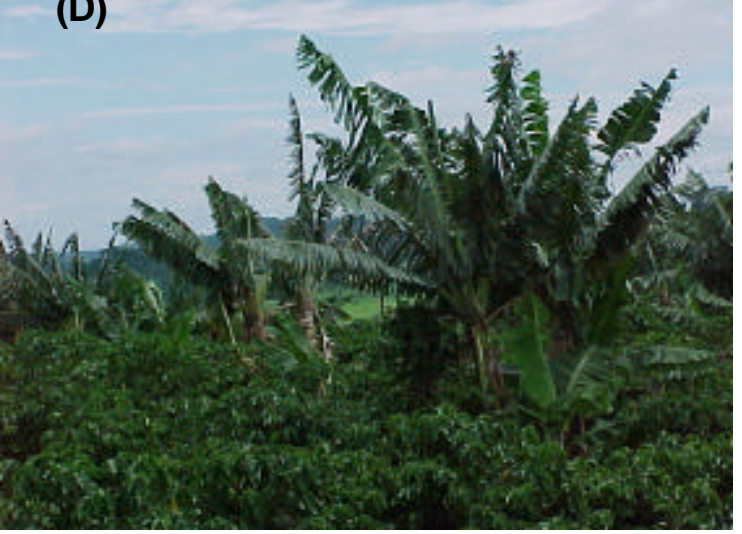

Figura 4 - Vista da parcela de café consorciada com banana 'Prata Anã', nos meses de junho de 2001 (A), outubro de 2001 (B), setembro de 2002 (C) e dezembro de 2003 (D), em Mococa, SP 
A condução da cultura do café foi realizada com os tratos culturais de acordo com as instruções técnicas para a região (Thomaziello et al., 2000) e para a cultura da bananeira seguiram-se as recomendações de Moreira (1987). Nas bananeiras, ressalta-se a realização da técnica do desbaste, que é feito para favorecer o maior desenvolvimento e produção da planta, eliminando-se os pés que já produziram e os excessos de brotação para as produções seguintes. Durante o período experimental foram realizados desbastes na bananeiras nas seguintes datas: 20/12/2001, 8/3/2002, 10/10/2002, 17/12/2002, 22/1/2003, 28/4/2003 e 22/1/2004.

\subsection{Avaliações microclimáticas}

Durante o período de outubro de 2001 a novembro de 2003, foram realizadas avaliações das interações microclimáticas nos sistemas de produção de café em monocultivo e consorciado com banana 'Prata Anã', que serão descritas a seguir.

\subsubsection{Caracterização microclimática}

Os dados microclimáticos foram coletados nos sistemas cultivado a pleno sol e consorciado durante os meses de outubro de 2001 a setembro de 2002. O estudo de caracterização microclimática envolveu a medição das seguintes variáveis: radiação solar global, saldo de radiação, temperatura do ar, umidade relativa do ar e velocidade do vento.

A radiação solar global foi medida com tubos solarímetros (TSL, Delta T Devices), instalados acima do dossel da cultura de café (1,9 metros de altura), para melhor caracterizar as condições ambientais onde se encontra a maioria do dossel dos cafeeiros. O saldo de radiação foi obtido com saldo radiômetros (Q7, REBS e NR-Lite, Keppen \& Zonen), instalados a aproximadamente 3 metros de altura. Todos os saldo radiômetros foram calibrados contra um padrão secundário, com o objetivo de corrigir possíveis alterações no fator de calibração em função do tempo de construção.

A temperatura do ar e a umidade relativa do ar foram determinadas com conjunto psicrométrico (Vaisala, HMP 45C), protegidos com abrigo micrometeorológico, constituídos de doze pratos plásticos sobrepostos (RM YOUNG, Gill), instalados na altura do dossel das plantas de café. A velocidade do vento foi obtida com anemômetros (RM YOUNG, 03001-L), instalados a 2 metros de altura.

Os sensores foram acoplados a um sistema automático de aquisição de dados (Campbell Scientific Inc., CR10X), tendo sido programado para leituras a cada 20 
segundos, médias a cada 15 minutos e obtenção dos valores médios diários (umidade relativa do ar e velocidade do vento), extremos diários (temperatura) e integração diária (radiação solar global e saldo de radiação). Na Figura 5 é apresentado um esquema da instalação dos sensores na parcela consorciada café com banana 'Prata Anã' utilizado no presente trabalho.

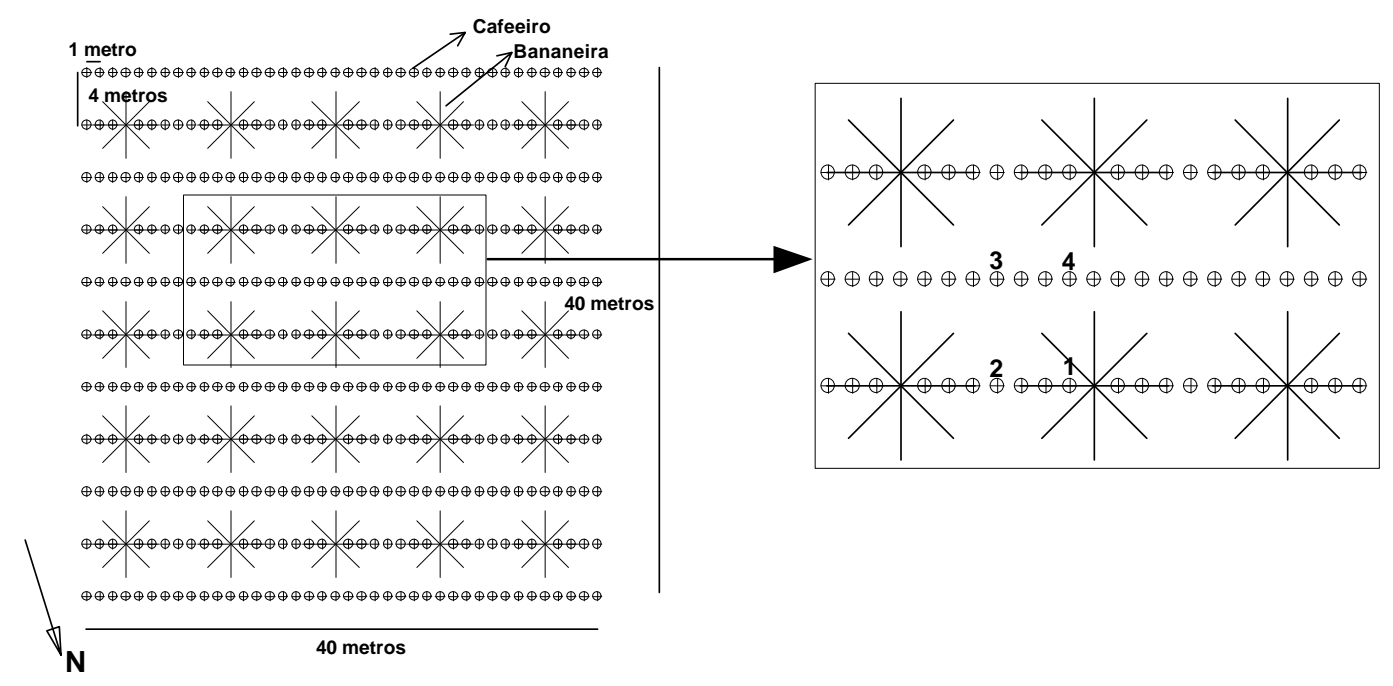

Figura 5 - Representação esquemática da posição de instalação de sensores na parcela consorciada em relação a planta de banana

A amostragem da radiação solar global foi feita na forma de quadrante em quatro pontos do sistema (Pontos amostrais 1 a 4), conforme realizada por Wallace (1996) em um sistema agroflorestal de grevílea com milho. O saldo de radiação foi amostrado na parcela do pleno sol e em três pontos do sistema consorciado (Pontos amostrais 1 a 3). A temperatura do ar, umidade relativa do ar e velocidade do vento foram amostrados nos pontos amostrais 1 e 3 , procurando caracterizar dois extremos dentro da parcela consorciada. Na Figura 6 são apresentadas ilustrações dos sensores instalados na parcela consorciada.

Visando possibilitar comparação, as avaliações microclimáticas foram realizadas simultaneamente em uma parcela de café cultivada a pleno sol, onde os sensores de saldo de radiação, temperatura do ar, umidade relativa do ar e velocidade do vento foram instalados na mesma altura do que os do sistema consorciado. 

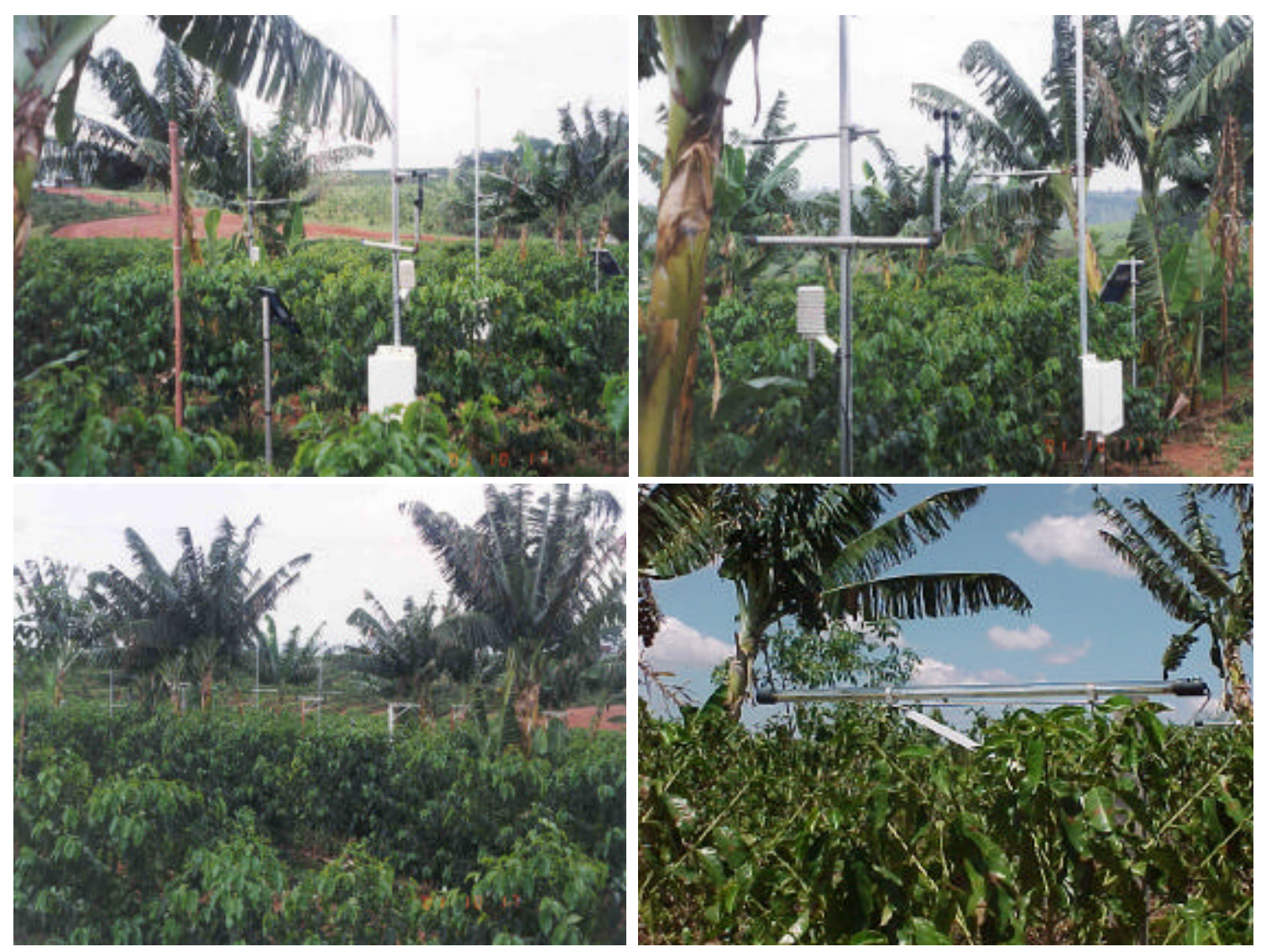

Figura 6 - Vista da instalação dos sensores na parcela de café consorciada com banana 'Prata Anã', em Mococa, SP

Foram utilizados dados meteorológicos da Estação meteorológica de primeira classe, pertencente ao Polo Regional de Desenvolvimento Tecnológico dos Agronegócios do Nordeste Paulista, em Mococa, situada a aproximadamente 500 metros do experimento, para a representação da radiação solar global no cultivo a pleno sol e com o objetivo de subsidiar a discussão dos resultados obtidos.

Para complementar a discussão sobre o comportamento da umidade atmosférica, foram calculados a pressão de saturação (equação 2) e a pressão atual de vapor (equação 3), visando a obtenção do défice de pressão de vapor (diferença entre a pressão de saturação e a pressão atual de vapor), segundo as equações utilizadas por Pereira et al. (1997): 


$$
\begin{gathered}
\left.e s=0,61 * 10^{\left[\frac{7,5^{*} t}{237,3+t}\right]}\right] \\
e a=\frac{e s^{*} U R \%}{100}
\end{gathered}
$$

em que es é a pressão de saturação de vapor $(\mathrm{kPa})$, t é a temperatura do ar $\left({ }^{\circ} \mathrm{C}\right)$, ea é a pressão atual de vapor ( $\mathrm{kPa}$ ) e UR\% é a umidade relativa (\%).

Modelos de regressão linear foram ajustados, pelo método dos quadrados mínimos, para explicar o comportamento da radiação solar global e do saldo de radiação, além da relação entre essas duas variáveis no cultivo consorciado. As médias por estação do ano dos dados diários dos parâmetros temperatura do ar (valores máximos e mínimos), umidade relativa do ar, pressão atual de vapor e velocidade do vento foram submetidos ao teste $t$ (Vieira, 1980) para médias com variâncias equivalentes, adotando-se os níveis de $5 \%$ e $1 \%$ de probabilidade, para detectar diferenças entres os pontos amostrais.

\subsubsection{Análise microclimática durante episódios de resfriamento do ar}

Durante os meses do período de inverno dos anos de 2002 (31 de maio a 31 de agosto) e 2003 (28 de maio a 28 de setembro), foram realizadas observações da variabilidade no plano horizontal de temperatura do ar e da folha e saldo de radiação, com o objetivo de verificar a dimensão da influência da planta usada como cultura consorciada no ambiente e nas plantas de café próximas a ela, durante a ocorrência de episódios de intenso resfriamento noturno (Caramori et al., 1996).

Os sensores de temperatura do ar e da folha e saldo de radiação foram instalados na linha de cafeeiros a partir de uma planta de bananeira (Figura 7). A medição da temperatura da folha foi realizada com termopar de cobre-constatã, colocados em contato com a página inferior de uma folha do terço superior de um cafeeiro, de acordo com o utilizado por Caramori et al. (1996). 

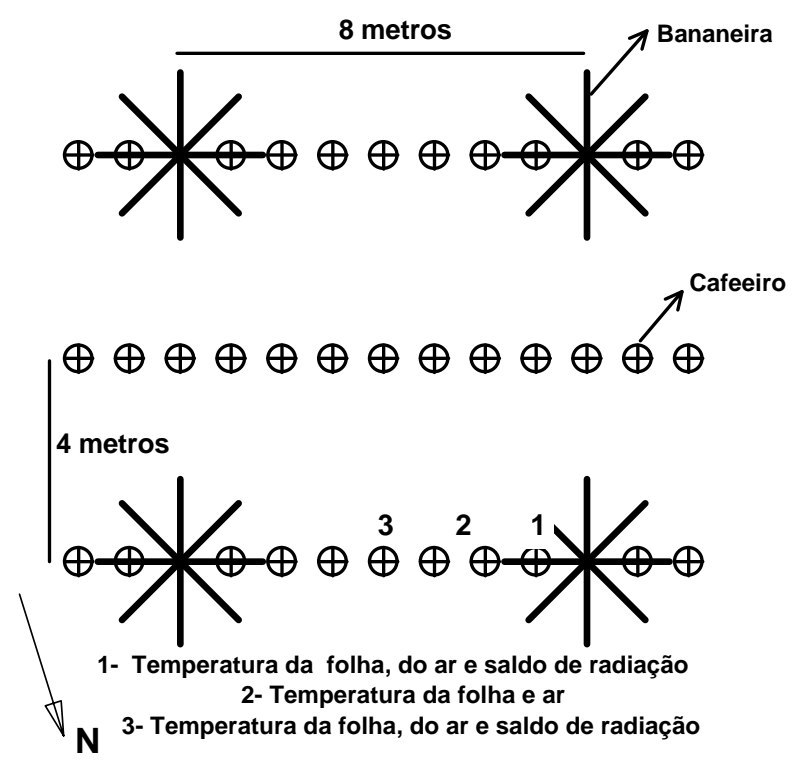

Figura 7 - Representação esquemática de instalação de sensores durante o período de inverno na parcela consorciada em relação a uma planta de banana

A temperatura do ar foi obtida na altura do dossel dos cafeeiro, sendo determinada por termopar de cobre-constantã, protegido com abrigo micrometeorológico, constituídos de seis pratos plásticos sobrepostos (RM YOUNG, Gill). O saldo de radiação foi obtido com saldo radiômetros (Q7, REBS), instalados a aproximadamente 3 metros de altura.

Para possibilitar comparação, as avaliações microclimáticas foram realizadas simultaneamente em uma parcela de café cultivada a pleno sol, onde os termopares para medição das temperaturas do ar e folhas, além do sensor de saldo de radiação, foram instalados na mesma altura que os do sistema consorciado. Além disso, foram instalados dois anemômetros (RM YOUNG, 03001-L), na altura de $2 \mathrm{~m}$, sendo um em cada sistema de produção.

Os sensores de saldo de radiação, temperatura e velocidade do vento, foram acoplados a um sistema automático de aquisição de dados (Campbell Scientific Inc., CR10X), tendo sido programado para leituras a cada 20 segundos, médias a cada 15 minutos, além dos valores extremos de temperatura da folha e do ar. 


\subsubsection{Características aerodinâmicas e energéticas}

Para a realização da caracterização aerodinâmica e energética dos diferentes sistemas de cultivo, a partir de dezembro de 2002, foram realizadas medições de gradientes de temperatura do bulbo seco e bulbo úmido e velocidade do vento, em períodos alternados, durante diferentes épocas do ano.

Os sensores utilizados para as medidas micrometeorológicas foram instalados em torre no centro das parcelas (cultivo a pleno sol e consorciado). Para as medidas dos gradientes de temperatura do bulbo seco e do bulbo úmido, foram utilizados psicrômetros aspirados construídos de acordo com Marin et al. (2001) e, para velocidade do vento, anemômetros (RM YOUNG, 03001-L e ENGESPAÇO), ambos posicionados em sete níveis acima da superfície do solo (Tabela 1). Para a obtenção do teor de umidade do ar, foi calculada a pressão atual de vapor, a partir da equação psicrométrica, de acordo com Pereira et al. (2003):

$$
e a=e s(t u)-A^{*} P^{*}(t s-t u)
$$

em que, ea é a pressão atual de vapor $(\mathrm{kPa})$, es(tu) é a pressão de saturação de vapor para o termômetro de bulbo úmido(equação 2), $A^{*} P$ é a constante psicrométrica, obtida a a partir da multiplicação do coeficiente psicrométrico $A=6,7.10^{-40} \mathrm{C}$ (psicrõmetros ventilados) por $\mathrm{P}$ (Pressão atmosférica local) $(\mathrm{kPa})$ e (ts-tu) é a diferença entre as temperaturas do bulbo seco e úmido.

Para as medidas do saldo de radiação (SR), utilizou-se de um saldo-radiômetro (REBS, Q7), posicionado a uma altura de $5 \mathrm{~m}$ da superfície do solo, quando as medidas foram realizadas no cultivo consorciado e a $3 \mathrm{~m}$ da superfície do solo, quando as medidas foram realizadas no cultivo a pleno sol. Para a medida do fluxo de calor para o solo $(G)$, foram utilizadas duas placas de fluxo de calor (MIDDLETON), sendo uma instalada na projeção da copa dos cafeeiros e outra na entrelinha, enterradas a $2 \mathrm{~cm}$ de profundidade.

Os dados foram coletados por um sistema de aquisição (CAMPBELL Sci., CR10X), com medidas a cada 1 minuto e médias a cada hora.

As medições foram realizadas em períodos alternados nos dois sistemas de cultivos, com o objetivo de se obter as caracterizações energéticas e aerodinâmicas em dias representativos das estações do ano. No cultivo a pleno sol, as medições foram realizadas nos períodos de 11 a 16 de janeiro, 7 a 10 de fevereiro, 26 a 31 de julho e 30 de 
setembro a 6 de outubro de 2003, totalizando 23 eventos. No sistema consorciado, as medições foram realizadas nos períodos de 10 a 16 de dezembro de 2002, 26 a 30 de março, 16 a 20 de abril, 2 a 9 de julho e 4 a 10 de novembro de 2003, totalizando 29 eventos.

Tabela 1. Altura de instalação de psicrômetros e anemômetros em dois sistemas de cultivo de café, em Mococa, SP

\begin{tabular}{lcccccc}
\hline \multirow{2}{*}{ Nível } & \multicolumn{2}{c}{$\begin{array}{c}\text { Cultivo a pleno sol * } \\
\text { Psicrômetro }\end{array}$} & \multicolumn{2}{c}{$\begin{array}{c}\text { Cultivo a pleno sol } \\
\text { A* }\end{array}$} & \multicolumn{2}{c}{$\begin{array}{c}\text { Cultivo Consorciado } \\
\text { Psicrômetro }\end{array}$} \\
\cline { 2 - 7 } Anemômetro & Psicrômetro & Anemômetro \\
\hline 1 & 0,75 & 0,97 & 0,75 & 0,97 & 1,85 & 2,07 \\
2 & 1,40 & 1,63 & 1,70 & 1,93 & 2,97 & 3,20 \\
3 & 1,98 & 2,18 & 2,18 & 2,41 & 3,80 & 4,03 \\
4 & 2,60 & 2,96 & 2,60 & 3,02 & 4,23 & 4,59 \\
5 & 3,05 & 3,41 & 3,05 & 3,41 & 4,88 & 5,11 \\
6 & 4,02 & 4,38 & 4,02 & 4,38 & 5,88 & 6,24 \\
7 & 6,00 & 6,36 & 6,00 & 6,36 & 7,93 & 8,29 \\
\hline
\end{tabular}

* Medidas de 11 a 16 de janeiro e 7 a 10 de fevereiro de 2003

** Medidas de 26 a 31 de julho e 30 de setembro a 6 de outubro de 2003

$\mathrm{Na}$ Figura 8 são apresentadas ilustrações das medidas que foram efetuadas durante dezembro de 2002 no sistema consorciado e em janeiro de 2003 no sistema cultivado a pleno sol. Na Tabela 2 são apresentados os valores médios de altura do dossel das plantas de café e banana durante os períodos amostrais.

Tabela 2. Altura média do dossel das plantas de café e bananeira nos diferentes períodos amostrais em experimento de café a pleno sol e consorciado com bananeira 'Prata Anã', em Mococa, SP

\begin{tabular}{lccc}
\hline \multirow{2}{*}{ Período amostral } & Tipo de cultivo & \multicolumn{2}{c}{ Altura $(\mathrm{m})$} \\
\cline { 3 - 4 } & & Café & Banana \\
\hline 10 a 16 de dezembro de 2002 & Consorciado & 1,88 & 4,50 \\
11 a 16 de janeiro de 2003 & Pleno sol & 1,94 & \\
7 a 10 de fevereiro de 2003 & Pleno sol & 1,96 & \\
26 a 30 de março de 2003 & Consorciado & 2,00 & 4,50 \\
16 a 20 de abril de 2003 & Consorciado & 2,00 & 4,50 \\
2 a 9 de julho de 2003 & Consorciado & 2,10 & 4,50 \\
26 a 31 de julho de 2003 & Pleno sol & 2,15 & \\
30 de setembro a 6 de outubro de 2003 & Pleno sol & 2,18 & \\
5 a 10 de novembro de 2003 & Consorciado & 2,13 & 4,50 \\
\hline
\end{tabular}



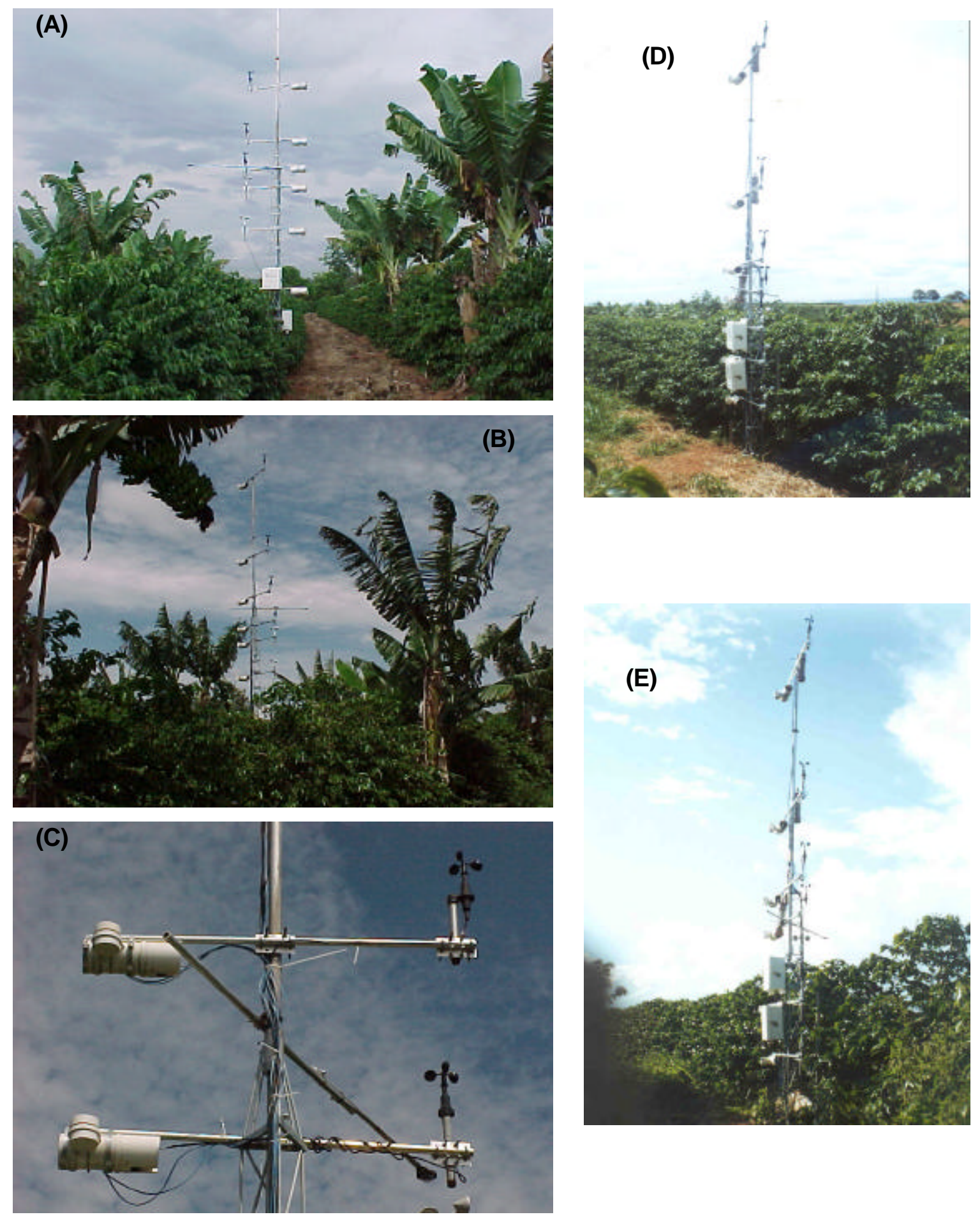

Figura 8 - Vista da instalação dos sensores para obtenção dos perfis no sistema consorciado ( $A, B)$ e cultivo a pleno sol (D , E), com detalhe de braços com psicrômetro e anemômetro e saldo radiômetro (C) 


\subsubsection{Caracterização aerodinâmica}

Para a análise da caracterização aerodinâmica foram selecionados perfis horários de todos os episódios, no período compreendido entre 6 e 19 horas, com estabilidade atmosférica próxima a neutralidade, determinada pelo número de Richardson $\left(\mathrm{R}_{\mathrm{i}}\right)$, proposto por Richardson em 1926, utilizado por Rosemberg (1974):

$$
R i=\left[g\left(\frac{d \theta}{d z}\right)\right]\left[\left[T a\left(\frac{d u}{d z}\right)^{2}\right]^{-1}\right.
$$

onde g é a aceleração da gravidade $\left(\mathrm{cm} \cdot \mathrm{seg}^{-2}\right), \mathrm{d} \theta / \mathrm{dz}$ e du/dz são os gradientes de temperatura potencial e velocidade do vento e Ta é a temperatura potencial (K) média entre os dois níveis de medida. Os gradientes de temperatura potencial foram substituídos pelos gradiente de temperatura do ar, por se tratar de medidas realizadas próximas à superfície (Kustas et al., 1989; Pereira, 1996)

Atmosfera em condição de estabilidade próxima a neutralidade ocorre quando $R_{i} \rightarrow 0$. Os limites do número de Richardson para tal condição foram considerados entre $-0,029<R_{i}<0,015$ (Kustas et al., 1989; Sentelhas et al., 1993). Para o cálculo do número de Richardson foram considerados os gradientes entre os níveis 3-6, e 4-6 para os cultivos conduzidos a pleno sol e consorciado, respectivamente.

Para cada perfil em condições de atmosfera próxima a neutralidade (Rosemberg, 1974), foram determinados o deslocamento do pleno zero (d), o comprimento da rugosidade $\left(z_{0}\right)$ e a velocidade característica $\left(u^{*}\right)$, com dados medidos acima do topo da cultura, sendo utilizados os anemômetros dos níveis 3 a 7 no cultivo a pleno sol e 4 a 7 no cultivo consorciado (Tabela 1), caracterizando o escoamento sobre a vegetação de porte alto, dado por:

$$
u=\left(\frac{u^{*}}{K}\right) \cdot \operatorname{Ln}\left[\frac{(z-d)}{z_{0}}\right]
$$

onde $u$ é a velocidade do vento $\left(\mathrm{m} \cdot \mathrm{s}^{-1}\right), u^{*}$ é a velocidade característica $\left(\mathrm{m} \cdot \mathrm{s}^{-1}\right), \mathrm{K}$ é a constante de Von Karman $(0,4)$ e $z$ a altura de medida $(\mathrm{m}), d$ é o deslocamento do plano zero $(m)$ e $z_{0}$ é o comprimento da rugosidade $(m)$ (Rosemberg, 1974).

Para a determinação de $d, z_{0} \in u^{*}$, utilizou-se o método estatístico que encontrava o menor valor da soma dos quadrados dos desvios de $u=Y$ e $\operatorname{Ln}(z-d)=X$, a partir da 
simulação dos valores de $d$. O valor mais adequado de $d$ foi aquele que minimizou o somatório dos desvios, ou seja, maximizou o valor de $\mathrm{R}^{2}$. Em decorrência determinou-se os valores de $u^{*}$ e $z_{o}$, a partir do coeficiente angular da reta e interceptação, respectivamente, de acordo com Pereira et al. (1997).

Para a determinação dos parâmetros aerodinâmicos, bem como a avaliação da da interdependência dos valores de $u^{*}$ com $d$ e $z_{0}$, no cultivo a pleno sol foram agrupados os perfis obtidos na primeira e segunda época de amostragem (11 a 16 de janeiro e 7 a 10 de fevereiro de 2003) e terceira e quarta época de amostragem (26 a 31 de julho e 30 de setembro a 6 de outubro de 2003). Para o cultivo consorciado foram agrupados os perfis obtidos na primeira, segunda e terceira época de amostragem (10 a 16 de dezembro de 2002, 26 a 30 de março de 2003 e 16 a 20 de abril de 2003). Esse agrupamento foi realizado em função das características de dossel serem semelhantes entre as referidas épocas de amostragem.

Para avaliar o efeito da direção do vento na caracterização aerodinâmica, foram separados os perfis com ventos predominantemente paralelos e perpendiculares ao sentido dos renques, sendo que para a direção perpendicular foram consideradas as direções entre leste e norte e entre oeste e sul e paralelos as direções entre norte e oeste e sul e leste, obtidas no posto meteorológico.

\subsubsection{Balanço de energia}

O método da razão de Bowen é baseado numa relação que leva em consideração os gradientes de temperatura do bulbo seco e úmido, medidos em alturas conhecidas e um fator de ponderação $\mathrm{W}$, que depende da temperatura do ar e do coeficiente psicrométrico.

A partir dos dados obtidos, determinou-se a razão de Bowen $(\beta)$ como utilizado por Pereira et al. (1997):

$$
\beta=\left[\frac{\Delta T u}{(1-W) \Delta T s}-1\right]^{-1}
$$

onde $\Delta \mathrm{Tu}$ é a diferença de temperatura do bulbo úmido entre as alturas de medida $\left({ }^{\circ} \mathrm{C}\right), \Delta$ Ts é a diferença de temperatura do bulbo seco entre as alturas de medida $\left({ }^{\circ} \mathrm{C}\right)$ e W é um fator de ponderação que depende da temperatura do bulbo úmido (Tu) e da constante psicrométrica $(\gamma)$, podendo ser calculado através das equações propostas por Wilson \& Rouse (1972) e Viswanadham et al. (1991), utilizadas por Pereira et al.(1997): 


$$
\begin{aligned}
& W=0.407+0,0145 T u, \text { para } 0<T u<16^{\circ} \mathrm{C} \\
& W=0,483+0,01 T u, \text { para } 16,1<T u<32^{\circ} \mathrm{C}
\end{aligned}
$$

em que Tu é a temperatura média do bulbo úmido entre as alturas de medida.

Empregando-se a razão entre o calor sensível $(H)$ e latente $(\lambda E)$ proposta por Bowen (equação 10) e a equação simplificada do balanço de energia (equação 11), foram calculados o fluxo de calor latente $(\lambda E)$ (equação 12) e o fluxo de calor sensível $(H)$ (equação 13), para os episódios nos dois sistemas de cultivo:

$$
\begin{gathered}
\beta=\frac{H}{\lambda E} \\
S R+F S+\lambda E+H=0 \\
\lambda E=-\frac{(S R+F S)}{(1+\beta)} \\
H=\beta * \lambda E
\end{gathered}
$$

Conforme sugerido por Perez et al. (1999), citado por Marin (2003), nas situações em que $\beta<-0,75$, o fluxo de calor latente foi considerado igual a energia disponível (SRFS), desprezando-se o fluxo de calor sensível. O valor do fluxo de calor para o solo (FS) foi obtido com a média dos sensores instalados na projeção da copa dos cafeeiros e outra na entrelinha. Os valores dos fluxos foram calculados para intervalos horários e somados para obtenção dos totais diurnos.

No cultivo consorciado, os gradientes de temperatura de bulbos seco e úmido utilizados nos cálculos foram obtidos a partir dos conjuntos psicrométricos instalados nos níveis 2 e 6 (Tabela 1), como ao utilizado por Pereira et al. (2003) para um pomar de lima ácida, devido a distribuição das bananeiras no cultivo consorciado ser semelhante a distribuição de árvores no pomar utilizado por esses autores. No cultivo a pleno sol os 
gradientes de temperatura de bulbos seco e úmido foram obtidos a partir dos conjuntos psicrométricos instalados nos níveis 3 e 6 (Tabela 1), situados acima do dossel dos cafeeiros de acordo com o trabalho de Gutierrez \& Meinzer (1994), para um cultivo de cafezal em renque.

A evapotranspiração de referência (Eto) foi calculada com os dados obtidos no posto meteorológico situado próximo ao experimento, de acordo com a parametrização de Allen et al. (1998) apresentada por Pereira et al. (2002):

$$
\text { ETo }=\frac{0,408 s(S r-G)+\frac{\gamma 900 U_{2}(e s-e a)}{T+273}}{s+\gamma\left(1+0,34 U_{2}\right)}
$$

onde Eto é a evapotranspiração de referência em mm.dia ${ }^{-1}$; Sr é o saldo de radiação em MJ.m $\mathrm{m}^{-2} \cdot \mathrm{dia}^{-1}$, dado por:

$$
S r=0,574 R g
$$

onde $\mathrm{Rg}$ é a radiação solar global em MJ.m ${ }^{-2} \cdot$ dia $^{-1}$ (Pereira et al., 1998, citado por Pereira et al. (2002)); G é o fluxo de calor para o solo $\left(\mathrm{MJ} \mathrm{m}^{-2} \cdot \mathrm{dia}^{-1}\right) ; \gamma=0,063 \mathrm{kPa} \cdot{ }^{\circ} \mathrm{C}^{-1}$ é a constante psicrométrica; $U_{2}$ é a velocidade do vento a $2 \mathrm{~m}$ de altura $\left(m . s^{-1}\right)$; es é a pressão de saturação de vapor $(\mathrm{kPa})$; ea é a pressão atual de vapor $(\mathrm{kPa}) ; \mathrm{T}$ é a temperatura do ar $\left({ }^{\circ} \mathrm{C}\right)$ e $s$ é a declividade da curva de pressão de vapor $\left(\mathrm{kPa} \cdot{ }^{\circ} \mathrm{C}^{-1}\right)$, determinada pela seguinte expressão:

$$
s=\frac{4098 e s}{(T+237,3)^{2}}
$$




\subsection{Avaliações na cultura}

Durante o período de setembro de 2001 a junho de 2004, foram feitas avaliações de crescimento, desenvolvimento fenológico e de índices de produção nas parcelas experimentais do sistema consorciado de café com bananeira 'Prata Anã' e nas parcelas em monocultivo de café. Na Figura 9 é apresentada a parcela útil utilizada para obtenção dos índices de produção do sistema consorciado (esquerda) bem como o detalhe de quatro pontos amostrais dentro da parcela, onde foram realizadas avaliações nos cafeeiros, de crescimento, desenvolvimento fenológico e índices de produção por planta (direita).
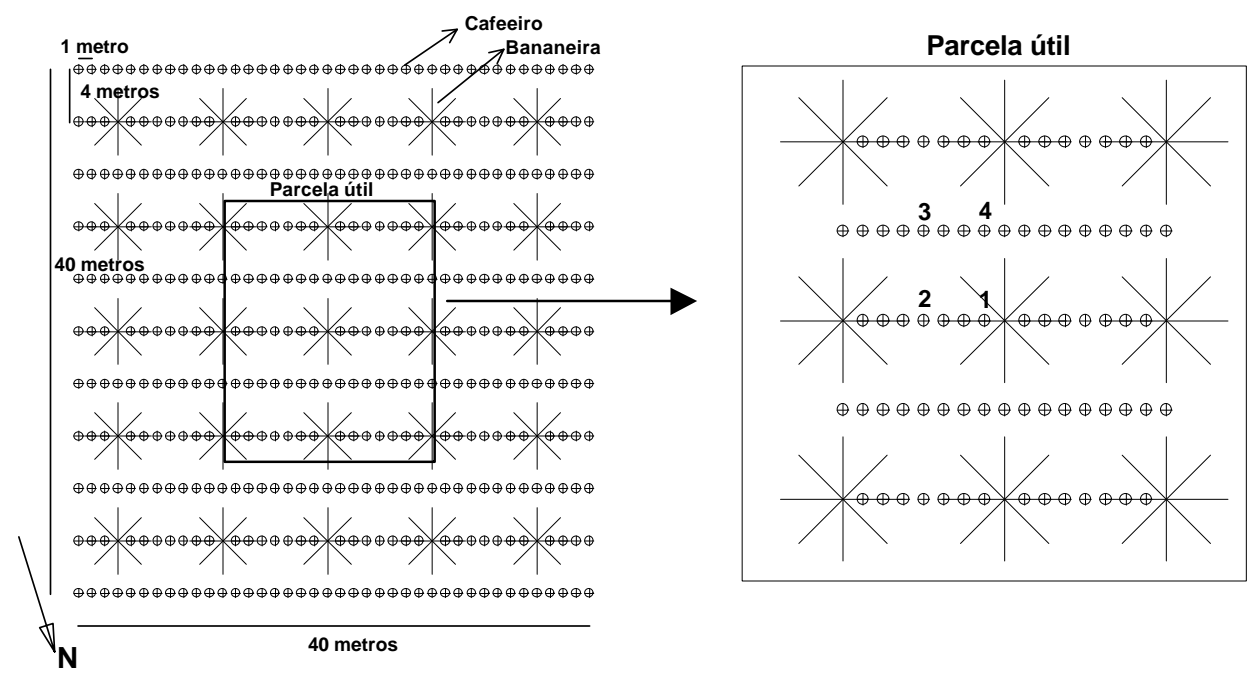

Figura 9 - Representação esquemática da parcela útil para fins de avaliação de produção e detalhamento da posição individual de plantas de café dentro da parcela consorciada

\subsubsection{Crescimento de plantas}

Nas plantas selecionadas nas parcelas de monocultivo e cultivo consorciado (Pontos de 1 a 4), em um total de seis repetições, foram realizadas avaliações de altura das plantas e diâmetro da copa no final de cada estação do ano. A altura foi determinada fazendo-se uso de uma régua topográfica colocada paralelamente ao caule do cafeeiro, medindo-se desde a superfície do solo até a gema apical do ramo ortotrópico. O diâmetro da copa foi determinado com a régua topográfica colocada transversalmente ao ramo 
ortotrópico em relação à linha de cafeeiros, medindo-se a maior distância entre o primeiro par de folhas presentes nos ramos plagiotrópicos opostos.

\subsubsection{Fenologia}

\subsubsection{Elaboração de escala fenológica}

No período de 2000/2001, foi desenvolvida uma escala fenológica (Pezzopane et al., 2003b), por meio de observações realizadas em cafeeiros da cultivar Mundo Novo de C. arabica L., localizados no Centro Experimental Central, do Instituto Agronômico (IAC), em Campinas (SP).

Para o estudo foram consideradas fases, ou seja, períodos significativos no decorrer do ciclo fenológico do cafeeiro, sendo perfeitamente identificáveis por alterações morfológicas nas plantas. Foram feitas fotografias para a identificação de 12 estádios fenológicos, principalmente para o período reprodutivo (após o repouso das gemas) (Anexo A).

Aos estádios considerados que vão desde gemas dormentes até o grão seco, foram atribuídas valores númericos como os descritos a seguir: (0) Gema dormente; (1) Gema entumecida; (2) Abotoado; (3) Florada; (4) Pós-florada (5) Chumbinho; (6) Expansão dos frutos; (7) Grão verde; (8) Verde Cana; (9) Cereja; (10) Passa; (11) Seco.

\subsubsection{Desenvolvimento fenológico}

Utilizando-se a escala apresentada no item anterior, notas de desenvolvimento fenológico foram atribuídas no período compreendido de agosto de 2001 a junho de 2004, nas plantas selecionadas nas parcelas de monocultivo e cultivo consorciado com banana 'Prata Anã' (Pontos de 1 a 4), em um total de seis repetições,

Nas plantas selecionadas foi marcado um ramo com orientação norte, no terço médio superior da planta, em até duas floradas que ocorrerem no ano. Nos ramos marcados na primeira florada, foram retiradas todas as flores das floradas subseqüentes e nos ramos da segunda florada serão retirados os chumbinhos da primeira florada e as flores das floradas subseqüentes. Posteriormente, foram atribuídas as notas do desenvolvimento fenológico em todos os ramos marcados, em intervalos de 7 a 10 dias, tendo sido considerado o estádio atual de desenvolvimento aquele que apresentasse mais de $50 \%$ de ocorrência no ramo. 


\subsection{3 Índices de Produção}

\subsubsection{Produção e rendimento}

Ao final da safra nos anos de 2002, 2003 e 2004, quando as plantas apresentavam maior parte dos frutos nos estádios de maturação cereja e passa, foi realizada a colheita nas parcelas úteis $\left(320 \mathrm{~m}^{2}\right)$ do sistema de produção em monocultivo de café e consorciado com banana 'Prata Anã', em um total de quatro repetições.

$\mathrm{Na}$ mesma ocasião foi realizada a colheita nas plantas selecionadas nas parcelas de cultivo consorciado com banana 'Prata Anã' (Pontos de 1 a 4 - Figura 9), em um total de oito repetições.

Após o procedimento de colheita, as produções foram pesadas em balança de precisão, obtendo-se a produção em "café da roça" e retirada uma amostra de até $4 \mathrm{Kg}$ por repetição, que foram acondicionadas em sacos de nylon e permaneceram em secagem natural no terreiro até atingirem o teor de umidade de aproximadamente $11 \%$, tendo sido posteriormente pesadas para a obtenção da produção de café em coco.

Além disso, as amostras foram processadas em máquinas de beneficiamento, obtendo-se a massa de café beneficiado. A partir desses dados foi estimado o rendimento (relação entre a massa dos grãos beneficiados e a massa da produção em coco, expressa em porcentagem), que foi utilizado como base para o cálculo de café beneficiado por planta.

\subsubsection{Tipo de semente}

O fruto do cafeeiro é uma drupa, contendo geralmente duas lojas e uma única semente em cada loja. Quando isto ocorre, a semente que assim se desenvolve é classificada do tipo chato, com uma face plana e outra convexa. Quando uma única semente se desenvolve no fruto, toma uma forma arredondada e se denomina moca. Se mais de um óvulo se desenvolve de uma loja do ovário, as sementes resultantes ficam embricadas umas às outras, tomam formas irregulares e são denominadas conchas (Fazuoli, 1977).

Para a determinação dos vários tipos de sementes foi utilizada uma amostra de até $0,4 \mathrm{~kg}$ por repetição, já beneficiada e que foi utilizada no estudo de rendimento. Os três 
tipos de sementes foram separados manualmente e pesados em balança de precisão. As porcentagens foram calculadas em relação à massa total de café beneficiado.

\subsubsection{Massa de sementes}

Para a determinação da massa de sementes, sementes do tipo chato, identificadas no item anterior, foram separadas, contando-se 100 sementes do tipo chato de cada amostra e determinando sua massa.

\subsubsection{Análise estatística}

O crescimento dos cafeeiros, determinado pela taxa de crescimento em altura e diâmetro das plantas nas avaliações realizadas, foram comparados entre os sistemas de produção, bem como entre os diferentes pontos amostrais do sistema consorciado, com o uso da "análise de intervalos de confiança" (95\%), (Vieira, 1980). O mesmo tipo de análise estatística foi utilizada para comparação da produção, rendimento e massa de 100 sementes entre o cultivo de café a pleno sol e consorciado.

Para avaliar a variabilidade espacial da produção em relação ao rendimento e a massa de 100 sementes, no sistema consorciado, foi realizada a análise de variância e o teste de Tukey, a um nível de 5\% de probabilidade para comparação das médias, como utilizado por Banzatto \& Kronka (1992). 


\section{RESULTADOS E DISCUSSÃO}

\subsection{Condições meteorológicas durante o período experimental}

Com o objetivo de descrever e caracterizar as condições meteorológicas durante o período experimental, na Figura 10 é apresentado o extrato do balanço hídrico, segundo Camargo \& Camargo (1993), relativo ao período de julho de 2001 a junho de 2004, onde valores positivos indicam excedentes hídricos e os negativos, deficiência hídrica ou falta de chuva. Ainda no Anexo B, são apresentados os dados meteorológicos obtidos no Posto Meteorológico de primeira classe, situado a aproximadamente 500 metros do experimento.

O primeiro ano agrícola do período experimental (2001-2002) apresentou o início das chuvas em setembro, com ocorrência de excedentes hídricos a partir de novembro. Até o início do mês de março de 2002, o período chuvoso apresentou elevados excedentes hídricos (cerca de $700 \mathrm{~mm}$ ), temperaturas amenas e alta umidade relativa do ar.

A partir de março de 2002, iniciou-se um período de deficiência hídrica, sendo que o mês de abril de 2002 apresentou elevados valores de temperatura máxima (valor médio mensal de $32,2^{\circ} \mathrm{C}$ ), com baixa umidade relativa (média de $62,5 \%$ no mês) e praticamente ausência de chuvas, quando iniciou o período seco que perdurou até o final do mês de outubro de 2002 (Figura 10A), embora tenha sido verificada ocorrência de chuvas durante o mês de maio (44 mm), no início e final do mês de setembro e no final de outubro. O mês de outubro apresentou temperaturas médias cerca de $3^{\circ} \mathrm{C}$ acima do normal, acentuando a deficiência hídrica. O ano de 2002, durante o período de março a outubro totalizou cerca de $420 \mathrm{~mm}$ de deficiência hídrica, em base decendial.

O período compreendido durante os meses de novembro de 2002 e fevereiro de 2003 apresentou excedente hídrico em torno de 560mm (Figura 10A e 10B), sendo que a partir de março iniciou-se um período de ocorrência de deficiência hídrica, que foi interrompido por ocorrência de chuvas até o mês de junho, tendo sido inclusive verificado 
ocorrência de excedentes no início de maio. A partir de junho de 2002, a deficiência hídrica foi constante, totalizando $250 \mathrm{~mm}$ até o final de outubro (Figura 10B), embora tenham sido verificados pequenas quantidades de chuva a partir de julho. Deve-se ressaltar que o período seco do ano de 2003 foi menos rigoroso que o de 2002.

No final do ano de 2003 iniciou-se um período de excedentes hídricos que perdurou até o início de março, tendo nesse período ocorridas interrupções de ocorrência de chuvas, sendo verificada deficiência hídrica no final e dezembro. Um fato interessante é que, a partir do início de março, quando foram verificados períodos com deficiências hídricas, as chuvas não cessaram, identificando no ano de 2004 um outono de característica chuvosa.
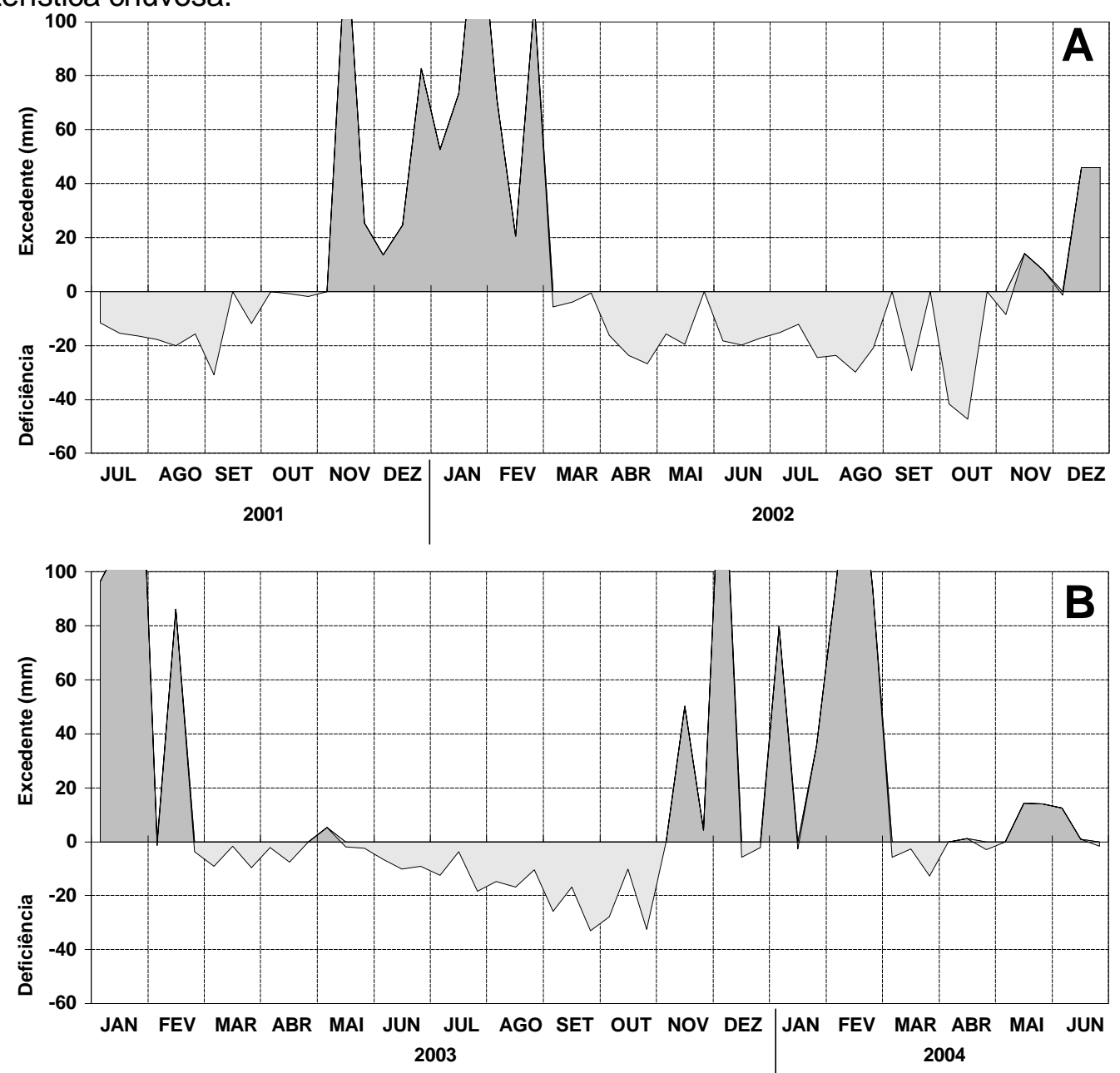

Figura 10 - Extrato do balanço hídrico $(C A D=100 \mathrm{~mm})$, durante os meses de julho de 2001 a dezembro de 2002 (A) e janeiro de 2003 a junho de 2004 (B), em Mococa, SP 


\subsection{Caracterização microclimática}

\subsubsection{Energia radiante e balanço de radiação}

\subsubsection{Radiação solar global}

$\mathrm{Na}$ Tabela 3, são apresentados os valores médios mensais da incidência da radiação solar global $(\mathrm{RG})$ no cultivo a pleno sol e nos quatro pontos amostrais do sistema consorciado no período de outubro de 2001 a setembro de 2002 e na Figura 11, é apresentada a variação sazonal da relação entre a radiação solar global nos quatro pontos do cultivo consorciado, bem como a média dos pontos amostrais e a radiação solar global no cultivo a pleno sol.

Tabela 3. Valores médios mensais de radiação solar global $\left(M J \cdot m^{-2} \cdot\right.$ dia $\left.^{-1}\right)$ em cultivo de café a pleno sol e em diferentes pontos amostrais de cultivo de café consorciado com bananeira 'Prata Anã', em Mococa, SP, no período de outubro de 2001 a setembro de 2002

\begin{tabular}{lcccccc}
\hline \multirow{2}{*}{ Mês } & \multicolumn{5}{c}{$\begin{array}{c}\text { Radiação solar global }\left({\mathrm{MJ} . \mathrm{m}^{-2} \text {. dia }}^{-1} \text { ) }\right. \\
\text { Cultivo Consorciado }\end{array}$} \\
\hline Outubro & Pleno sol & \multicolumn{5}{c}{} \\
\cline { 2 - 6 } Novembro & 21,3 & 14,8 & 17,7 & 18,6 & 19,0 & 17,5 \\
Dezembro & 19,4 & 13,3 & 17,4 & 16,9 & 17,7 & 16,3 \\
Janeiro & 19,0 & 10,3 & 17,9 & 16,9 & 17,5 & 15,6 \\
Fevereiro & 21,1 & 8,9 & 19,6 & 19,3 & 19,5 & 16,8 \\
Março & 17,4 & 6,5 & 14,5 & 15,5 & 15,4 & 13,0 \\
Abril & 20,7 & 8,7 & 16,0 & 19,3 & 18,9 & 15,7 \\
Maio & 20,2 & 8,3 & 16,8 & 19,2 & 18,0 & 15,6 \\
Junho & 15,0 & 6,4 & 11,9 & 12,8 & 13,1 & 11,1 \\
Julho & 15,6 & 6,4 & 12,6 & 12,8 & 14,1 & 11,5 \\
Agosto & 14,6 & 5,3 & 13,2 & 12,8 & 13,0 & 11,1 \\
Setembro & 16,7 & 8,4 & 15,2 & 15,0 & 14,8 & 13,4 \\
\hline
\end{tabular}

${ }^{*}$ Média dos pontos amostrais dentro da parcela consorciada

Pelos dados obtidos verifica-se que as plantas de bananeira 'Prata Anã', utilizadas no sistema de cultivo consorciado promoveram uma atenuação na transmissividade da radiação solar global até a altura das plantas de café. Os valores médios de RG mostraram diferenças quando comparados os vários pontos amostrais dentro do sistema consorciado. 
No ponto amostral 1, próximo às plantas de banana, a transmissividade foi mais influenciada, variando entre 35 e 69\%, com maiores atenuações ocorrendo no período de fevereiro a julho. No ponto 2, situado entre duas bananeiras, a transmissividade variou entre 77 e 94\%, sendo que a atenuação foi maior no período de março a junho. Nos pontos 3 e 4 (linha central de cafeeiros), a atenuação foi menor, com relação entre a radiação solar no cultivo consorciado e no cultivo a pleno sol sempre superior a $80 \%$.

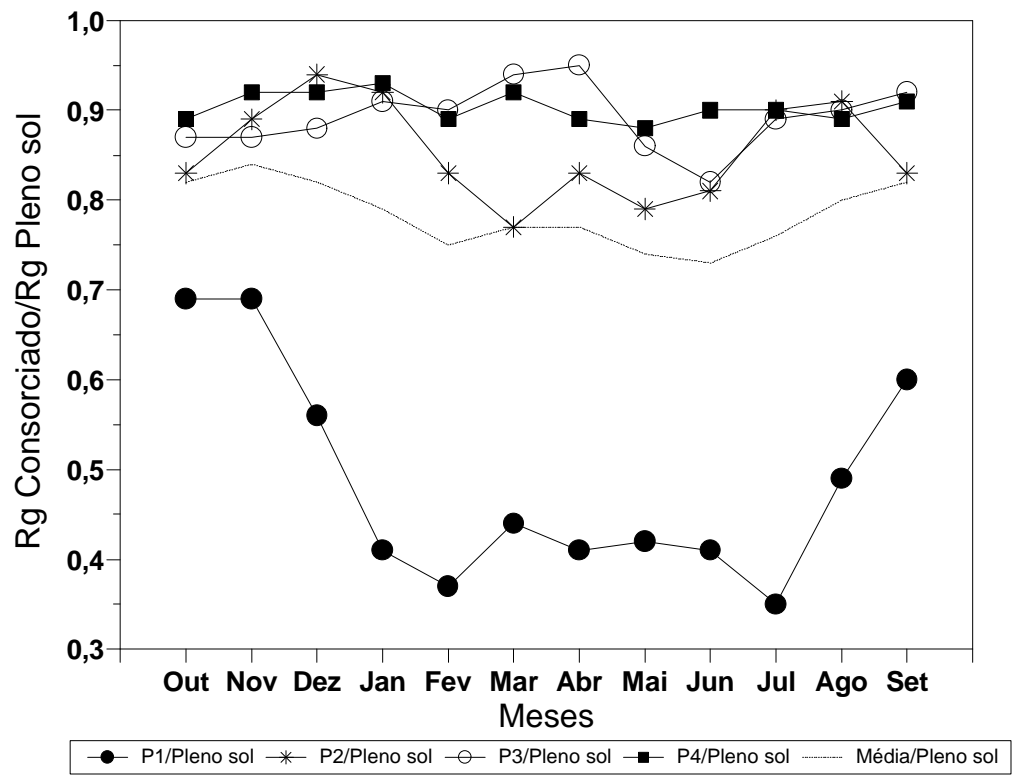

Figura 11 - Variação sazonal da relação entre a radiação solar global no cultivo de café consorciado (RG consorciado) e no cultivo de café a pleno sol (RG Pleno sol), em Mococa, SP, no período de outubro de 2001 a setembro de 2002

Quando analisada a média dos quatro pontos amostrais, observou-se uma variação temporal na transmissividade da RG, com variação mensal de 75 a 84\%, influenciada principalmente pelos pontos amostrais 1 e 2 do sistema consorciado. As maiores atenuações ocorreram no período de janeiro a julho e as maiores transmissividades no período de agosto a dezembro, sendo que essa variação pode ser explicada pelo aumento do ângulo zenital que ocorre nos meses de outono e inverno nas condições de cultivo do hemisfério sul, fazendo com que as plantas de banana próximas a esses pontos amostrais interceptem radiação por um maior período do dia em relação aos outros meses do ano.

Convém ressaltar que o desbaste das bananeiras, ocorrido nos meses de dezembro de 2001 e março de 2002, pouco influenciaram a interceptação da radiação 
solar global, tendo sido observada maior influência no segundo período de podas, quando a relação entre a radiação solar medida nos dois sistemas sofreu pequena elevação nos meses de março e abril de 2002. Farfan-Valencia et at. (2003) e Black \& Ong (2000) relatam que em cultivo arborizados de café, a transmissividade da radiação solar está relacionada com a época do ano, arquitetura da planta sombreadora e o arranjo espacial utilizado.

Os diferentes valores de RG obtidos na comparação entre os pontos estudados dentro do sistema consorciado, evidenciam uma variação espacial do balanço de radiação. Na Figura 12, é mostrada a incidência de radiação solar global em quatro episódios, em dias de céu limpo, selecionados nos dois sistemas de cultivo.

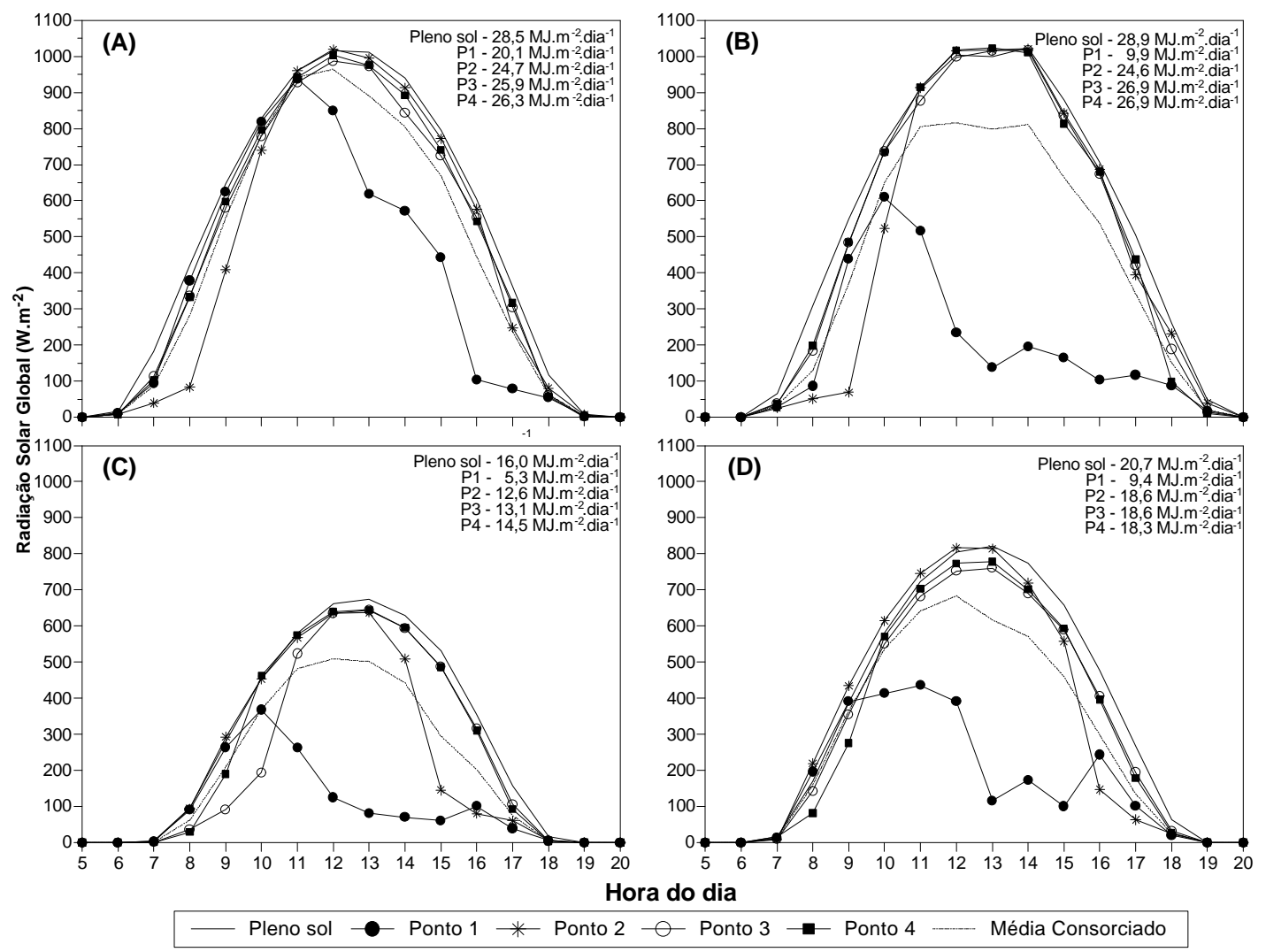

Figura 12 - Variação dos valores horários da radiação solar global (RG) em cultivo de café a pleno sol e em diferentes pontos amostrais de cultivo de café consorciado com banana 'Prata Anã', em Mococa, SP, nos dias 6/11/2001 (A), 5/2/2002 (B), 15/6/2002 (C) e 18/8/2002 (D) 
No dia 6/11/2001 (Figura 12A) a interceptação de radiação solar praticamente só ocorreu no ponto 2 , totalizando $13 \%$ durante o dia, e no ponto 1 , com total de $29 \%$, sendo que no ponto amostral 2 a interceptação mais significativa ocorreu no período até as 11 horas, enquanto que no ponto 1 ocorreu a partir das 11 horas. Fato semelhante ocorreu no dia 5/2/2002 (Figura 12B), sendo verificada maior atenuação no ponto 1 já a partir das 10 horas da manhã, totalizando $66 \%$ de RG interceptada. O mês de fevereiro foi um dos que apresentou menor transmissividade da RG para esse ponto amostral (37\%). Nos pontos 3 e 4, para estes episódios, a interceptação só ocorreu no período da manhã e final da tarde.

No dia 15/6/2002 (Figura 12C) a interceptação foi mais significativa, principalmente nos pontos 1,2 e 3 . No ponto amostral 1, a transmissividade foi baixa desde as 10 horas da manhã. No ponto 2, a atenuação ocorreu no período da tarde e no ponto 3 no período da manhã, até ao meio-dia. O mês de junho foi o que apresentou as maiores interceptações, com média mensal de 27\%. No dia 18/8/2002 (Figura 12D), a interceptação apresentou semelhanças com o episódio de fevereiro, apenas com diferença na quantidade de interceptação do ponto 1, que foi menor nesse episódio. Por outro lado, o ponto 2, neste episódio, apresentou maior interceptação no período da tarde.

A maior atenuação de radiação no ponto 1 verificada sempre no período vespertino, em todos os episódios, está relacionada com a exposição da parcela consorciada, orientada na face Nordeste. A diferença de transmissividade entre os diferentes pontos amostrais e as épocas do ano, verificada na Figura 12, pode ser explicada pela variação da trajetória aparente do sol, sendo que as maiores variações ocorreram nos pontos 1 (situado próximo a bananeira) e 2 (situado entre duas bananeiras).

A comparação dos valores diários obtidos de RG (cultivo a pleno sol) e da transmitida nos diferentes pontos de medição da parcela consorciada (média dos pontos amostrais), está apresentada na Figura 13. O coeficiente angular $(0,79)$ indica uma redução média da transmissividade de $21 \%$, promovida pelas plantas de bananeira no cultivo consorciado.

Pezzopane et al. (2003a) em trabalho realizado com cultivo consorciado de café com coqueiro anão verde na região de Garça, SP, obtiveram valores de atenuação da radiação solar incidente nas plantas de café em torno de $42 \%$ ao longo do ano. FarfanValencia et al. (2003) obtiveram porcentagens média de radiação fotossiteticamente ativa transmitida sobre plantas de café em sistemas agroflorestais na Colômbia entre 45 e 55\% para a espécie Cordia alliodora, 30 a 49\% em Pinus oocarpa e 64 a 68\% em Eucalyptus 
grandis. Camargo \& Pereira (1994) relatam que árvores de sombreamento em cultivo arborizados de café em regiões tropicais devem cobrir cerca de $20 \%$ da superfície, sendo que excessos de sombreamento podem ser prejudiciais ao desenvolvimento e produção dos cafeeiros, como o ocorrido nos experimentos de Carvalho et al. (1961) e Carvajal (1984), citado por Camargo \& Pereira (1994).

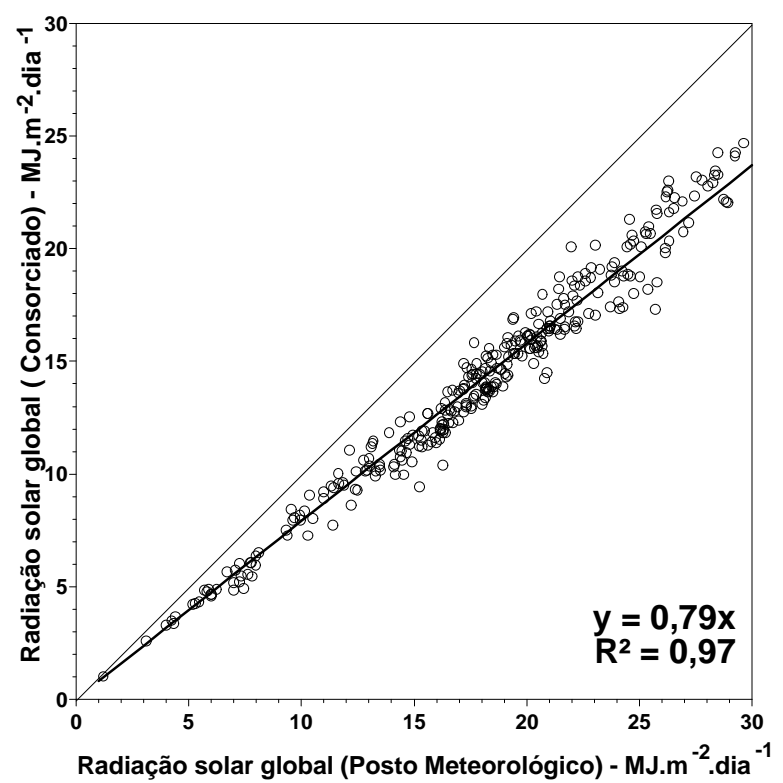

Figura 13 - Comparação entre os valores diários da radiação solar global (MJ.m $\left.\mathrm{m}^{-2} \cdot \mathrm{dia}^{-1}\right)$ em cultivo de café a pleno sol e consorciado com bananeira 'Prata Anã' (média dos pontos amostrais), em Mococa, SP, no período de outubro de 2001 a setembro de 2002

\subsubsection{Saldo de Radiação}

$\mathrm{Na}$ Tabela 4 estão apresentados os valores médios mensais do saldo de radiação (SR) no cultivo a pleno sol e em três pontos amostrais (Pontos amostrais 1 a 3 ) do sistema consorciado no período de outubro de 2001 a setembro de 2002. Na Figura 14, é apresentada a relação mensal média mensal entre os valores diários do saldo de radiação nos três pontos do sistema consorciado, bem como sua média e o SR no cultivo a pleno sol para o mesmo período. Pode ser verificado que as plantas de banana utilizadas no consórcio promoveram alteração no saldo de radiação em comparação ao cultivo a pleno sol, o que induziria alterações dos fluxos de calor sensível, latente e de calor para o solo (Pezzopane, 2001). 
No ponto 1 do sistema consorciado, próximo à planta de banana, o saldo de radiação foi mais afetado, principalmente a partir do mês de janeiro de 2002, quando permaneceu em média, entre 19 a 39\% do SR no cultivo a pleno sol até o mês de setembro de 2002, evidenciando uma forte redução. Nos pontos de observação 2 e 3 do sistema consorciado essa redução foi bem menos significativa, sendo que, para o ponto 2 , situado entre duas bananeiras, na maioria dos meses o SR permaneceu acima do cultivo a pleno sol. No período de outubro a fevereiro, o SR no ponto 2 do sistema consorciado permaneceu, em média diária, cerca de 10 a $20 \%$ superior em relação ao cultivo a pleno sol, sendo que as maiores diferenças foram em dias nublados, com baixa incidência de radiação solar. Fato semelhante ocorreu nos meses de julho e agosto.

Tabela 4. Dados mensais do saldo de radiação (SR - MJ.m ${ }^{-2} \cdot$ dia $\left.^{-1}\right)$ em um cultivo de café a pleno sol e em diferentes pontos amostrais de cultivo de café consorciado com bananeira 'Prata Anã', em Mococa, SP, no período de outubro de 2001 a setembro de 2002

\begin{tabular}{lccccc}
\hline \multirow{2}{*}{ Mês } & \multirow{4}{c}{$\begin{array}{c}\text { Saldo de Radiação }\left(\mathrm{MJ}^{-2} \mathrm{~m}^{-2} \text {.dia }\right. \\
\text { Cultivo Consorciado }\end{array}$} \\
\cline { 3 - 6 } & Pleno sol & \\
\cline { 3 - 6 } Outubro & 12,0 & Ponto 1 & Ponto 2 & Ponto 3 & Média* $^{-1}$ \\
Novembro & 11,6 & 10,3 & 12,5 & 11,5 & 11,5 \\
Dezembro & 10,7 & 6,8 & 12,9 & 11,7 & 11,8 \\
Janeiro & 12,4 & 4,8 & 12,0 & 10,7 & 9,7 \\
Fevereiro & 9,4 & 3,1 & 13,7 & 12,6 & 10,4 \\
Março & 11,4 & 3,1 & 9,7 & 9,7 & 7,5 \\
Abril & 9,4 & 1,8 & 10,4 & 11,9 & 8,5 \\
Maio & 6,0 & 1,4 & 8,7 & 9,5 & 6,7 \\
Junho & 5,6 & 2,2 & 6,3 & 5,9 & 4,5 \\
Julho & 4,9 & 1,2 & 5,8 & 5,0 & 4,4 \\
Agosto & 6,4 & 1,5 & 5,8 & 4,7 & 3,9 \\
Setembro & 8,00 & 3,1 & 7,7 & 6,2 & 5,2 \\
* Média dos pontos de & & 7,2 & 8,1 & 6,2 \\
\hline
\end{tabular}

* Média dos pontos de leitura dentro da parcela consorciada

No ponto 3 do sistema consorciado, os valores de SR permaneceram próximos aos do cultivo a pleno sol na maioria dos meses do ano, com reduções ou incrementos de SR inferiores a 10\%. Analisando os dados médios do três sensores do sistema consorciado, o SR permaneceu sempre acima de $70 \%$ em relação ao cultivo a pleno sol, influenciado principalmente pelo ponto de observação 1. 


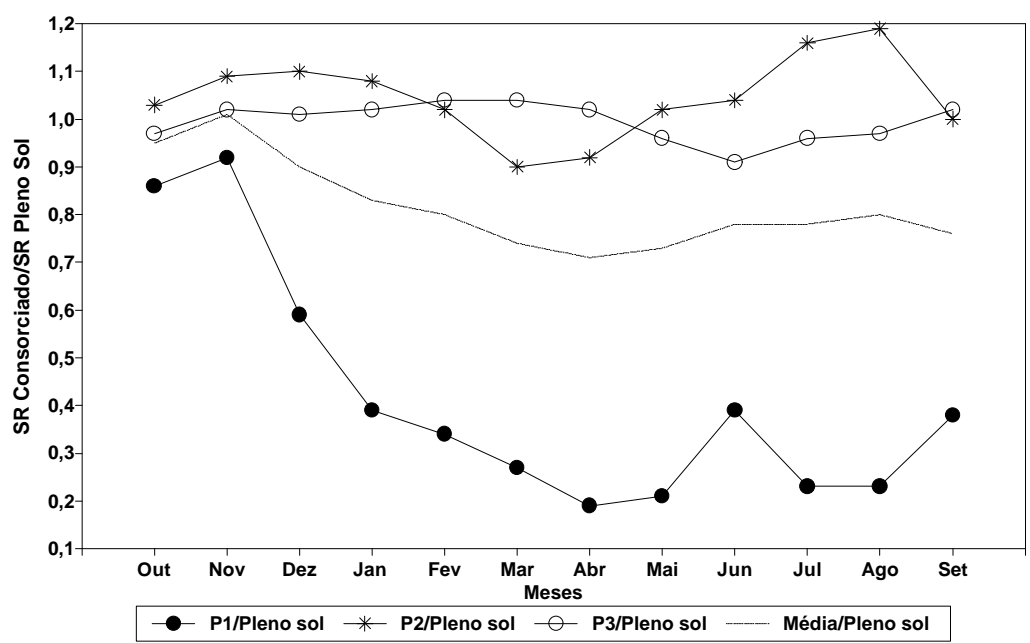

Figura 14 - Variação sazonal da relação entre o Saldo de Radiação em diferentes pontos amostrais de cultivo de café consorciado (SR consorciado) e o Saldo de Radiação no cultivo a Pleno Sol (SR Pleno sol), no período de outubro de 2001 a setembro de 2002, em Mococa, SP

Para melhor representação da influência do sistema consorciado no saldo de radiação, foram selecionados quatros episódios ao longo do ano, sendo dois com céu limpo e dois com céu nublado que estão apresentados na Figura 15 e na Tabela 5, onde os valores do saldo de radiação foram separados em período diurno (6 às 18 horas) e período noturno (18 e 6 horas).

No dia 28/10/2001 (Figura 15A), a curva do saldo de radiação apresentou um padrão típico observado em superfícies vegetais em condições de céu aberto em dia claro, com o SR no cultivo a pleno sol atingindo cerca de $700 \mathrm{~W} / \mathrm{m}^{2}$ ao meio dia e total de 17,21 MJ. $\mathrm{m}^{-2}$ para período diurno. No cultivo consorciado os valores foram próximos, com menor incidência no ponto 1 , que apresentou $82 \%$ de transmissividade em relação ao cultivo a pleno sol, afetada principalmente no período vespertino. No período noturno, o saldo foi negativo, resultado do balanço negativo entre a radiação emitida pela superfície (radiação terrestre) e a contra-radiação (atmosférica). O ponto 1 do sistema consorciado, como esperado, apresentou valores mais próximos a neutralidade, devido à menor perda energética proporcionada por trocas radiativas com as folhas de bananeira. Caramori et al. (1996), assim como Brenner (1996) também verificaram o efeito protetor de árvores utilizadas em cultivos arborizados. 


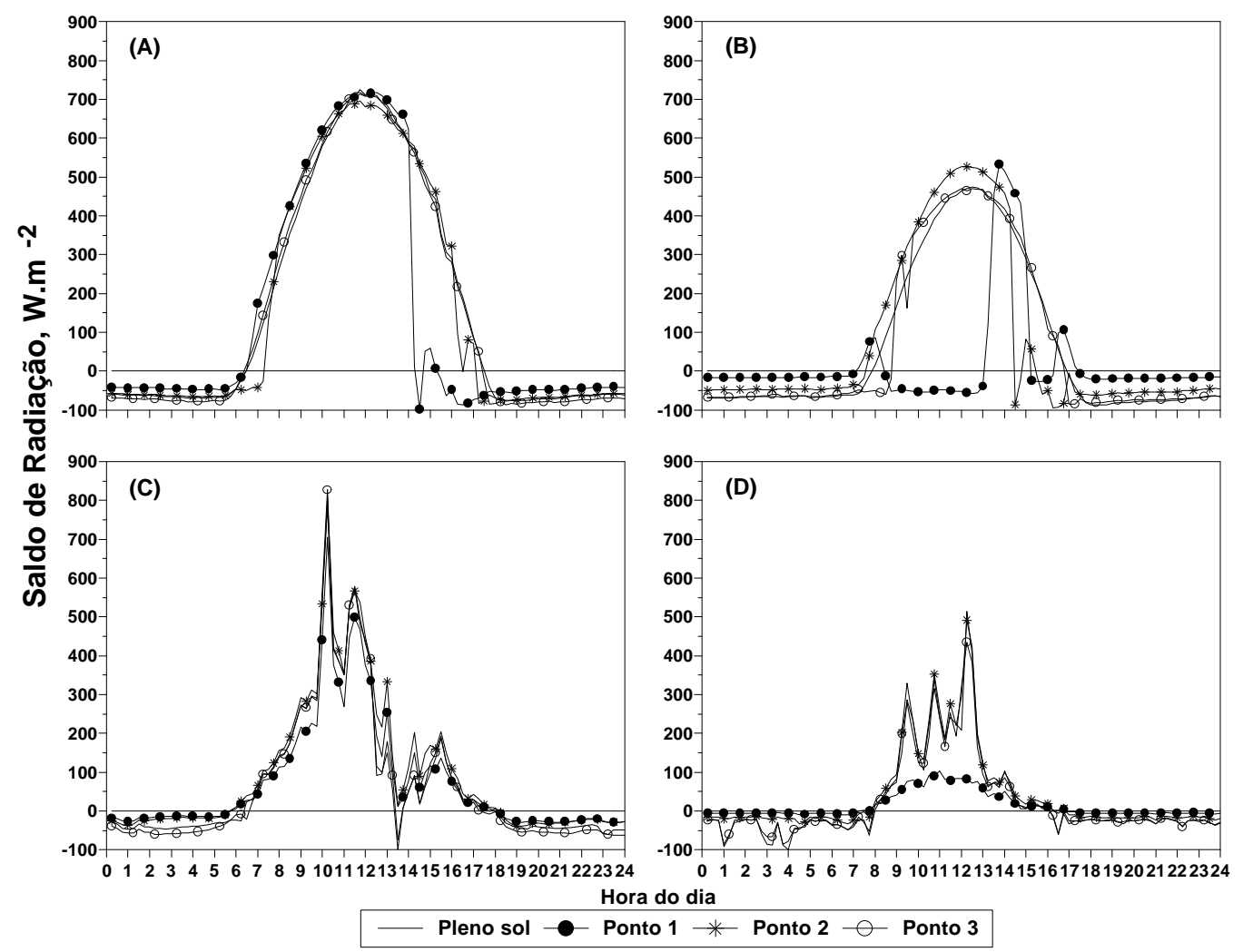

Figura 15 - Variação dos valores horários do saldo de radiação em cultivo de café a pleno sol e em diferentes pontos amostrais de cultivo de café consorciado com banana 'Prata Anã', em Mococa, SP, nos dias 28/10/2001 (A), 26/7/2002 (B), característicos de céu limpo e 23/11/2001 (C) e 23/7/2002 (D), nublados

Para o dia 26/7/2002, também em condição de céu limpo, a influência das plantas de banana foram mais significativas com relação a transmissividade mesmo para o período diurno. Em determinados períodos do dia, o SR foi maior na parcela consorciado do que no cultivo a pleno sol, principalmente para os pontos 2 e 3 no período matutino e ponto 1 no período vespertino, provavelmente quando o sensor recebia contribuição de contraradiação emitida pelas folhas das bananeiras. Nesse dia, para o período diurno, o SR do ponto 2 do sistema consorciado praticamente igualou o SR do cultivo a pleno sol. No período noturno pôde ser verificado, como no dia 28/10/2001, menores perdas radiativas dos pontos da parcela consorciada em relação ao cultivo a pleno sol. Diante disso, no total diário, o SR no ponto 2 do sistema consorciado foi $11 \%$ maior do que o cultivo a pleno sol. 
Tabela 5. Valores diários do saldo de radiação $\left(\mathrm{MJ} \mathrm{m}^{-2} \cdot \mathrm{dia}^{-1}\right)$ em um cultivo de café a pleno sol e em diferentes pontos amostrais de café consorciado com bananeira 'Prata Anã', em Mococa, SP, para quatro episódios selecionados

\begin{tabular}{|c|c|c|c|c|c|c|c|c|}
\hline \multirow{3}{*}{ Dia } & \multirow{3}{*}{ Período* } & \multicolumn{4}{|c|}{ Saldo de Radiação (MJ.m²) } & \multicolumn{3}{|c|}{ Razão de $\mathrm{Sr}^{* *}$} \\
\hline & & \multirow{2}{*}{ Pleno sol } & \multicolumn{3}{|c|}{ Consorciado } & \multirow{2}{*}{ P1/sol } & \multirow{2}{*}{ P2/sol } & \multirow{2}{*}{ P3/sol } \\
\hline & & & P1 & P2 & P3 & & & \\
\hline \multirow{3}{*}{ 28/10/2001 } & Diurno & 17,21 & 14,17 & 16,70 & 17,32 & 0,82 & 0,97 & 1,01 \\
\hline & Noturno & $-2,83$ & $-1,95$ & $-2,72$ & $-3,21$ & 0,69 & 0,96 & 1,14 \\
\hline & Total & 14,39 & 12,21 & 13,98 & 14,12 & 0,85 & 0,97 & 0,98 \\
\hline \multirow{3}{*}{ 23/11/2001 } & Diurno & 7,57 & 7,05 & 9,08 & 7,65 & 0,93 & 1,20 & 1,01 \\
\hline & Noturno & $-1,73$ & $-0,89$ & $-1,06$ & $-2,21$ & 0,51 & 0,61 & 1,28 \\
\hline & Total & 5,84 & 6,16 & 8,02 & 5,43 & 1,06 & 1,37 & 0,93 \\
\hline \multirow{3}{*}{ 23/7/2002 } & Diurno & 3,54 & 1,44 & 4,27 & 3,48 & 0,41 & 1,21 & 0,98 \\
\hline & Noturno & $-1,51$ & $-0,26$ & $-0,78$ & $-1,44$ & 0,17 & 0,51 & 0,95 \\
\hline & Total & 2,03 & 1,18 & 3,49 & 2,04 & 0,58 & 1,72 & 1,01 \\
\hline \multirow{3}{*}{ 26/7/2002 } & Diurno & 8,96 & 2,40 & 8,68 & 8,80 & 0,27 & 0,97 & 0,98 \\
\hline & Noturno & $-3,05$ & $-0,74$ & $-2,14$ & $-2,94$ & 0,24 & 0,70 & 0,96 \\
\hline & Total & 5,90 & 1,65 & 6,54 & 5,86 & 0,28 & 1,11 & 0,99 \\
\hline
\end{tabular}

* Período diurno: entre 6 e 18 horas; Período noturno: entre 18 e 6 horas; Total: total diário ** Relação entre o saldo de radiação do ponto amostral $(P n)$ no cultivo consorciado e o saldo de radiação no cultivo a pleno sol

Nos dias característicos de céu nublado, 23/11/2001 e 23/7/2002, o total diário de SR sobre o experimento foi menor, totalizando 5,84 e 2,03 MJ.m ${ }^{-2} \cdot$ dia $^{-1}$, respectivamente no cultivo a pleno sol (Tabela 5). Nos dois episódios, o SR no ponto 2 de leitura do cultivo consorciado, situado entre duas bananeiras, superou em $20 \%$ a incidência do cultivo a pleno sol no período diurno, enquanto que no período noturno ocorreu menor perda radiativa, ocasionando valores superiores de SR em relação ao cultivo a pleno sol, na ordem de 37 e $72 \%$, respectivamente. Em cultivos arborizados ocorre um aumento na proporção de radiação difusa, com característica multi-direcional e de baixa energia, que incide sobre a cultura protegida (Vandenbeldt \& Williams, 1992), o que se torna ainda mais evidente em dias nublados. É importante ressaltar que ocorrências de episódios como o do dia 23/7/2002, promoveram um aumento de cerca de $20 \%$ nos valores médios diários de SR no ponto 2 do sistema consorciado em relação ao sistema a pleno sol no mês de julho (Figura 15).

Para os mesmos episódios, o comportamento do SR no ponto 1 do sistema consorciado foi diferente, com baixa incidência no dia 23/7/2002, provavelmente quando o 
dossel da planta de banana sobre o sensor interceptou grande parte da radiação incidente. No ponto amostral 3 do sistema consorciado, na parte central da parcela, a incidência foi próxima do cultivo a pleno sol, com razão de incidência perto da unidade tanto nos valores diurnos quanto noturnos.

A comparação dos valores diários obtidos de SR (cultivo a plenos sol) e nos diferentes pontos de medição da parcela consorciada (média dos pontos amostrais), está apresentada na Figura 16

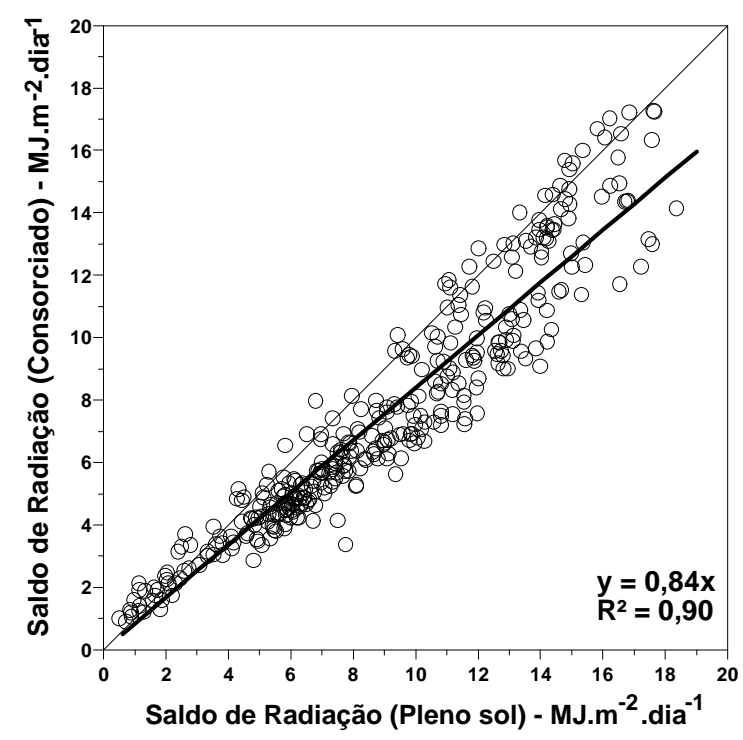

Figura 16 - Relação entre os valores diários do saldo de radiação $\left(M J \cdot \mathrm{m}^{-2} \cdot \mathrm{dia}^{-1}\right)$ em cultivo de café a pleno sol e em cultivo de café consorciado com bananeira 'Prata Anã' (média dos pontos amostrais), em Mococa, SP, no período de outubro de 2001 a setembro de 2002

O coeficiente angular $(0,84)$ indica uma redução da transmissividade média no ano de $16 \%$, promovida pelas plantas de bananeira no cultivo consorciado. Esses valores foram influenciados principalmente pelo ponto amostral 1 do sistema consorciado, situado próximo a planta de banana. Em dias com baixa incidência de radiação, com até 6 MJ.m ${ }^{2}$.dia ${ }^{-1}$ de saldo de radiação, como verificado nos episódios com céu nublado na Figura 15 e Tabela 5, o saldo de radiação no sistema consorciado superou o SR no cultivo a pleno sol, influenciado principalmente pela menor perda de radiação de onda longa para a atmosfera. 


\subsubsection{Relações entre Saldo de radiação e Radiação solar global}

Uma importante informação relacionada com o balanço de radiação em cultivos agrícolas, é a relação entre o saldo de radiação da cultura (SR) e a radiação solar global (RG), apresentada para os dois sistemas de cultivo em sua variação mensal na Tabela 6 e na Figura 17, para os meses de janeiro e julho.

Para o cultivo a pleno sol, a relação entre o SR e a RG variou de 0,62 no mês de janeiro a 0,34 em julho (Figura 17). Para o cultivo consorciado a relação variou de 0,68 em novembro a 0,35 em julho (Tabela 6). Quando analisado todo o período de medição, o SR representou $50 \%$ e $53 \%$ de $R G$ nos cultivos a pleno sol e consorciado, respectivamente .

Sentelhas \& Nascimento (2003), em estudo de relação SR/RG para um gramado em Piracicaba, encontraram variação anual da relação de 0,59 em fevereiro a 0,47 em maio, relacionando como principais causas dessa variação sazonal o maior coeficiente de reflexão da superfície gramada no período seco, além da nebulosidade e umidade do ar associados ao regime de chuvas. Segundo esses autores, essas variáveis interferem no balanço de ondas, havendo redução da perda de radiação na faixa de infravermelho termal sob condições de alta umidade do ar e com a presença de nuvens, o que resulta em maior saldo de radiação diário, aumentando a relação de $S R / R G$, como o ocorrido no mês de janeiro no dois sistemas de cultivo (Figura 17).

No mês de julho ocorreu a menor relação SR/RG nos dois sistemas de cultivo. Segundo Sentelhas \& Nascimento (2003), em meses com fotoperíodo menor que 12 horas, ocorre significativa elevação dos valores negativos do saldo de radiação, o que contribui para a diminuição das relações de SR/RG, como ocorrido no dia 26/7/2002 (Figura 15B e Tabela 5).

As relações de SR/RG nos meses de outubro a fevereiro apresentaram maiores diferenças entre os dois sistemas de cultivos, com maiores valores para o sistema consorciado (Tabela 6), devido principalmente ao maior saldo de radiação em dias chuvosos, como apresentado na Tabela 5 para o dia 23/11/2002, além da menor perda radiativa no sistema consorciado no período noturno, o que proporciona maiores valores de saldo de radiação. Também em função disso a relação média de SR/RG no sistema consorciado (53\%) foi maior que no cultivo a pleno sol (50\%). 
Tabela 6. Variação sazonal das relações entre saldo de radiação diário $(\mathrm{SR})$ e radiação solar global (RG) nos cultivos de café a pleno sol e consorciado com bananeira 'Prata Anã', em Mococa, SP, no período de outubro de 2001 a setembro de 2002. SP. Valores entre parênteses indicam o $R^{2}$

\begin{tabular}{lcc}
\hline Mês & $\begin{array}{c}\text { SR/RG } \\
\text { Café a pleno sol }\end{array}$ & $\begin{array}{c}\text { SR/RG } \\
\text { Café consorciado }\end{array}$ \\
\hline Outubro & $0,54(0,90)$ & $0,62(0,93)$ \\
Novembro & $0,57(0,94)$ & $0,68(0,98)$ \\
Dezembro & $0,58(0,93)$ & $0,64(0,93)$ \\
Janeiro & $0,62(0,97)$ & $0,64(0,83)$ \\
Fevereiro & $0,57(0,94)$ & $0,61(0,96)$ \\
Março & $0,55(0,93)$ & $0,53(0,91)$ \\
Abril & $0,47(0,68)$ & $0,43(0,69)$ \\
Maio & $0,41(0,79)$ & $0,41(0,86)$ \\
Junho & $0,36(0,62)$ & $0,38(0,55)$ \\
Julho & $0,34(0,80)$ & $0,35(0,72)$ \\
Agosto & $0,39(0,83)$ & $0,39(0,83)$ \\
Setembro & $0,47(0,93)$ & $0,44(0,83)$ \\
Ano & $0,50(0,81)$ & $0,53(0,75)$ \\
\hline
\end{tabular}

Marin (2003) destaca que essa informação, apesar de ser de fácil aplicação, não pode ser extrapolada para qualquer cafezal, mas apenas para aqueles cultivados em espaçamentos semelhantes e em mesma condição de porte.

Para cultivos de café, Jaramillo-Robledo (1994) encontrou a relação SR/RG, no período diurno, para a cv. Caturra com uma população de 10000 plantas.ha ${ }^{-1}$, igual a 0,74. Pezzopane et al. (2001) encontraram a relação de SR/RG para valores diários, de 0,61 para a cv. Obatã com uma população de 10000 plantas.ha $^{-1}$ e Marin (2003) encontrou a relação SR/RG igual a 0,49 para um cafezal da cv. Mundo Novo com uma população de 4000 planta.ha ${ }^{-1}$ nos meses de setembro e outubro, mostrando que a população de plantas, porte da planta e época do ano, além da cobertura vegetal da entrelinha tem influência na determinação dessa relação. 


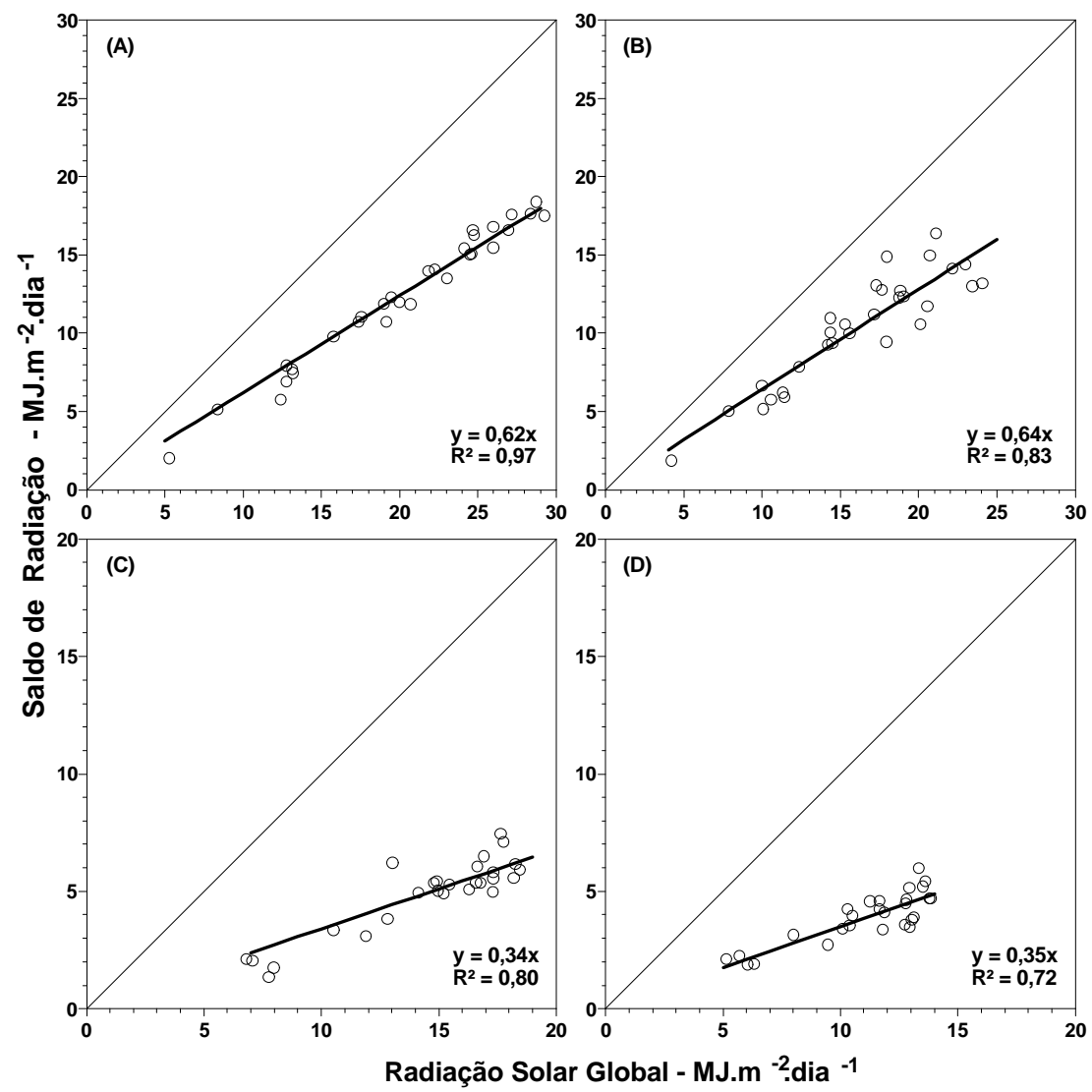

Figura 17 - Comparação entre os valores diários do saldo de radiação e a radiação solar global no cultivo de café a pleno sol nos meses de janeiro $(A)$ e junho $(C)$ de 2002 e consorciado com bananeira 'Prata Anã', nos meses de janeiro (B) e julho (D) de 2002, em Mococa, SP

\subsubsection{Velocidade do vento}

Os valores mensais da velocidade do vento $\left(\mathrm{m} . \mathrm{s}^{-1}\right)$ para o sistema de produção de café a pleno sol e o consorciado com bananeira 'Prata Anã', bem como a redução na incidência de vento, estão apresentados na Tabela 7. As médias quinquidiais da velocidade do vento para os dois sistemas de produção estão apresentados na Figura 18. Ressalta-se que os valores obtidos no sistema consorciado são relativos à média de dois sensores instalados na parcela. 
Tabela 7. Valores mensais de velocidade do vento $\left(m \cdot \mathrm{s}^{-1}\right)$, em um cultivo de café a pleno sol e consorciado com bananeira 'Prata Anã', em Mococa, SP, no período de outubro de 2001 a setembro de 2002

\begin{tabular}{lccccc}
\hline \multirow{2}{*}{ Mês } & \multicolumn{3}{c}{ Velocidade do vento $\left(\mathrm{m}^{-1} \mathrm{~s}^{-1}\right.$} & \multirow{3}{*}{$\begin{array}{c}\text { Redução** } \\
\%\end{array}$} \\
\cline { 2 - 4 } & Pleno sol & \multicolumn{3}{c}{ Consorciado } \\
\cline { 2 - 4 } & & Ponto 1 & Ponto 3 & Média* $^{*} n$ \\
\hline Outubro & 1,30 & 0,68 & 0,58 & 0,63 & 53 \\
Novembro & 1,19 & 0,54 & 0,49 & 0,52 & 58 \\
Dezembro & 1,21 & 0,32 & 0,58 & 0,45 & 64 \\
Janeiro & 1,16 & 0,54 & 0,58 & 0,56 & 53 \\
Fevereiro & 0,93 & 0,40 & 0,39 & 0,39 & 58 \\
Março & 0,90 & 0,57 & 0,44 & 0,50 & 45 \\
Abril & 0,79 & 0,51 & 0,40 & 0,46 & 42 \\
Maio & 0,75 & 0,40 & 0,39 & 0,40 & 47 \\
Junho & 0,71 & 0,41 & 0,35 & 0,39 & 47 \\
Julho & 1,00 & 0,57 & 0,55 & 0,56 & 46 \\
Agosto & 1,21 & 0,80 & 0,71 & 0,76 & 37 \\
Setembro & 1,15 & 0,84 & 0,75 & 0,79 & 31 \\
\hline
\end{tabular}

${ }^{*}$ Média dos pontos amostrais dentro da parcela consorciada

** \% de redução da incidência de vento na parcela consorciada

A redução da velocidade do vento promovida pelas bananeiras durante os meses do ano variou de 31 a 64\% em relação ao cultivo a pleno sol (Tabela 7), com média anual de $48 \%$, sendo mais significativa no período de outubro de 2001 a fevereiro de 2002, provavelmente devido ao maior enfolhamento da bananeira nesses meses. Também podese notar que o desbaste das bananeiras, ocorrido no final de dezembro e início de março (Figura 18) alteraram os valores da redução dos dois parâmetros nos períodos subseqüentes fazendo com que as reduções fossem um pouco menores durante o período de outono e de inverno.

Pezzopane et al. (2003a), observaram reduções superiores a 60\% na incidência de vento em um sistema consorciado de café com coqueiro anão verde. Camargo \& Pereira (1994), relatam que um dos maiores benefícios do cultivo consorciado de café é a redução da incidência de ventos, que causam danos físicos às folhas e reduzem seu crescimento (Caramori et al., 1986).

Os valores médios da velocidade do vento para o sistema de produção de café a pleno sol e o consorciado com bananeira 'Prata Anã' por estação do ano e os valores do teste $t$ de comparação de médias, estão apresentados na Tabela 8 , enquanto que na 
Figura 19, é apresentada a comparação por estação do ano, dos valores médios diários de velocidade do vento para os cultivos de café a pleno sol e consorciado com banana.

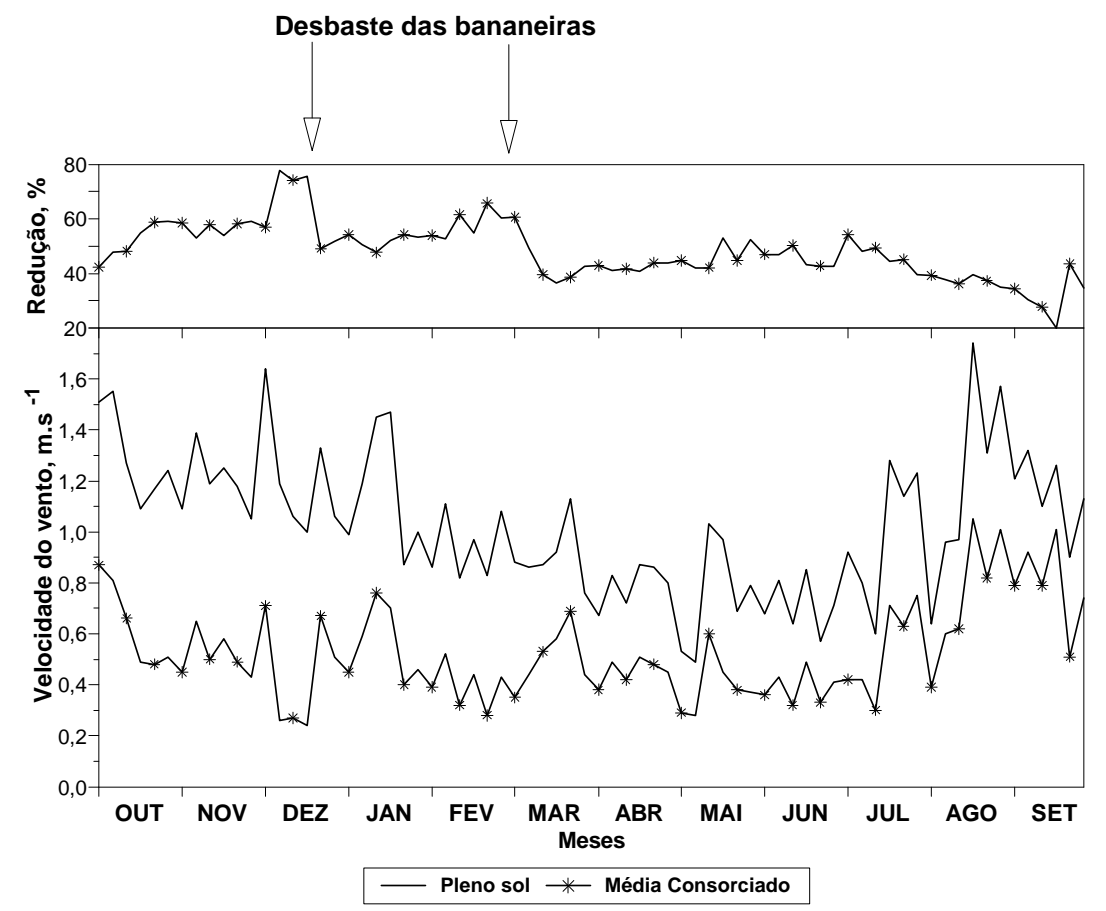

Figura 18 - Médias quinquidiais da velocidade do vento $\left(\mathrm{m} \cdot \mathrm{s}^{-1}\right)$ em cultivos de café a pleno sol e consorciado com banana 'Prata Anã', em Mococa, SP

Tabela 8. Médias da velocidade do vento $\left(m . s^{-1}\right)$ e valores do teste t de comparação de médias, em cultivo de café a pleno sol e em diferentes pontos amostrais de cultivo café consorciado com bananeira 'Prata Anã', em Mococa, SP, avaliadas em quatro estações do ano 

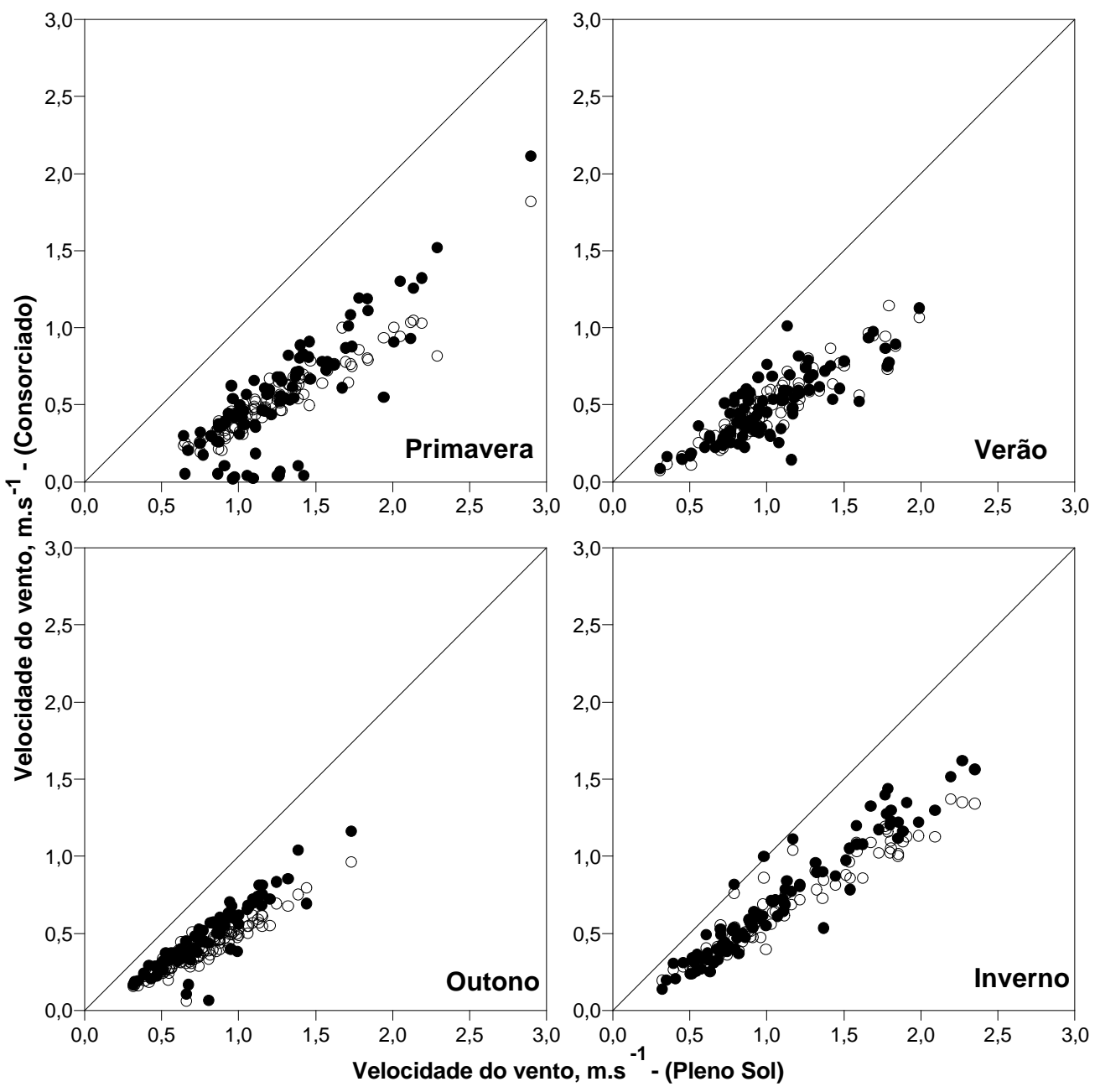

- Ponto $1 \bigcirc$ Ponto 3

Figura 19 - Comparação entre os valores diários da velocidade do vento $\left(\mathrm{m}^{\mathrm{s}} \mathrm{s}^{-1}\right)$ em cultivos de café a pleno sol e em diferentes pontos amostrais de cultivo de café consorciado com bananeira 'Prata Anã', para quatro estações do ano, em Mococa, SP

As diferenças entre os valores médios da velocidade do vento foram significativas, pelo teste t, para os dois pontos amostrais do sistema consorciado em todas as épocas do ano em relação a incidência no cultivo a pleno sol. Com relação a variabilidade espacial dentro do sistema consorciado, as menores médias, para todas as épocas do ano, com exceção do verão, foram obtidas no ponto 3 de amostragem, sendo verificada diferença significativa entre os pontos amostrais do sistema consorciado para o período de outono. 
Isso provavelmente ocorreu devido a predominância de vento do sentido nordeste que ocorre na região, de acordo com os dados normais do posto meteorológico.

\subsubsection{Temperatura do ar}

Os valores médios de temperatura máxima, mínima e média do ar para o sistema de produção de café a pleno sol e o consorciado com bananeira 'Prata Anã' por estação do ano estão apresentados na Tabela 9, enquanto que na Figura 20 é apresentada a comparação, por estação do ano, dos valores quinquidiais de temperatura do ar para os diferentes tipos de cultivo.

Tabela 9. Médias das temperaturas máxima, mínima e média $\left({ }^{\circ} \mathrm{C}\right)$ e valores do teste $t$ de comparação de médias, em cultivo de café a pleno sol e em diferentes pontos amostrais de cultivo café consorciado com bananeira 'Prata Anã', em Mococa, $\mathrm{SP}$, avaliadas em quatro estações do ano

\begin{tabular}{|c|c|c|c|c|c|c|}
\hline \multirow{2}{*}{ Época } & \multirow{2}{*}{ Pleno sol } & \multicolumn{2}{|c|}{ Consorciado } & \multicolumn{3}{|c|}{ Valor de t } \\
\hline & & $\mathrm{P} 1$ & P3 & Pleno sol -P1 & Pleno sol - P3 & $\mathrm{P} 1-\mathrm{P3}$ \\
\hline & \multicolumn{6}{|c|}{ Temperatura Máxima $\left({ }^{\circ} \mathrm{C}\right)$} \\
\hline Primavera & 30,7 & 30,4 & 31,5 & $0,59^{\text {ns }}$ & $1,49^{\text {ns }}$ & 2,07 * \\
\hline Verão & 31,7 & 31,1 & 32,7 & 1,39 ns & 2,14 * & 3,14 ** \\
\hline Outono & 30,9 & 31,0 & 32,5 & $0,27^{\mathrm{ns}}$ & 3,50 ** & 3,30 ** \\
\hline \multirow[t]{2}{*}{ Inverno } & 29,6 & 29,8 & 29,9 & $0,37^{\mathrm{ns}}$ & $0,92^{\text {ns }}$ & $0,56^{\text {ns }}$ \\
\hline & \multicolumn{6}{|c|}{ Temperatura Mínima (ํㅡ) } \\
\hline Primavera & 18,0 & 18,1 & 17,9 & $0,37^{\mathrm{ns}}$ & $0,35^{\text {ns }}$ & $0,71^{\mathrm{ns}}$ \\
\hline Verão & 19,1 & 19,4 & 19,1 & $0,98^{\text {ns }}$ & $0,34^{\text {ns }}$ & $0,66^{\text {ns }}$ \\
\hline Outono & 15,7 & 16,0 & 15,7 & $0,57^{\text {ns }}$ & $0,02^{\text {ns }}$ & $0,55^{\text {ns }}$ \\
\hline \multirow[t]{2}{*}{ Inverno } & 14,3 & 14,4 & 14,3 & $0,25^{\mathrm{ns}}$ & $0,10^{\text {ns }}$ & $0,15^{\mathrm{ns}}$ \\
\hline & \multicolumn{6}{|c|}{ Temperatura Média $\left({ }^{\circ} \mathrm{C}\right)$} \\
\hline Primavera & 23,5 & 23,5 & 23,6 & $0,28^{\text {ns }}$ & $0,62^{\mathrm{ns}}$ & $0,35^{\mathrm{ns}}$ \\
\hline Verão & 24,0 & 24,1 & 24,3 & $0,27^{\text {ns }}$ & $1,31^{\text {ns }}$ & $1,07^{\text {ns }}$ \\
\hline Outono & 22,4 & 22,5 & 22,7 & $0,45^{\text {ns }}$ & $1,01^{\text {ns }}$ & $0,58^{\text {ns }}$ \\
\hline Inverno & 21,1 & 21,2 & 21,3 & $0,28^{\text {ns }}$ & $0.53^{\text {ns }}$ & 0,26 ns \\
\hline
\end{tabular}

Os valores médios, por estação do ano, da temperatura máxima obtidos no ponto 1 (próximo às plantas de bananeira) do sistema consorciado não apresentaram diferenças significativas, pelo teste $\mathrm{t}$, quando comparados aos valores obtidos no cultivo a pleno sol, sendo menores na primavera $\left(30,7^{\circ} \mathrm{C}\right.$ no cultivo a pleno sol e $30,4^{\circ} \mathrm{C}$ no ponto 1$)$ e verão $\left(31,7^{\circ} \mathrm{C}\right.$ no cultivo a pleno sol e $31,1^{\circ} \mathrm{C}$ no ponto 1$)$, e ligeiramente superiores no outono- 
inverno $\left(0,1^{\circ} \mathrm{C}\right.$ e $0,2^{\circ} \mathrm{C}$, respectivamente). Quando o cultivo de café ocorre em condições de sombreamento elevado, como apresentado por Barradas \& Fanjul (1986) em um sistema agroflorestal de produção de café no México e por Miguel et al. (1995) em um cultivo arborizado de café com grevílea, as diferenças dos valores de temperatura máxima entre o sistema sombreado e o sistema de produção a pleno sol podem atingir até $5,0^{\circ} \mathrm{C}$, com valores inferiores no cultivo sombreado.

Em relação à variação espacial da temperatura máxima do ar dentro do sistema consorciado, pode ser verificado que no ponto de amostragem 3 (ponto central da parcela), os valores médios de temperatura máxima obtidos foram superiores ao cultivo a pleno sol e ao ponto 1 do sistema consorciado (Tabela 9), apresentando diferenças significativas no verão e outono. No período de verão a média das temperaturas máximas no ponto 3 do sistema consorciado permaneceu $1,6^{\circ} \mathrm{C}$ acima do ponto 1 do sistema consorciado e $1,0^{\circ} \mathrm{C}$ acima do cultivo a pleno sol, enquanto que no outono, a média das temperaturas máximas no ponto 3 do sistema consorciado permaneceu cerca de $1,5^{\circ} \mathrm{C}$ superior aos outros dois pontos amostrais, sendo que no mês de abril de 2002, as temperaturas máximas nesse ponto de amostragem, por vários dias, foi superior em três graus em relação ao cultivo a pleno sol (Figura $20 \mathrm{~B}$ ).

Ao se analisar as diferenças de temperatura máxima obtidas entre os dois pontos amostrais do sistema consorciado, é importante ressaltar que nos meses de verão e outono ocorreram as maiores interceptações de radiação solar incidente sobre o ponto amostral 1 do sistema consorciado (Figura 11), contribuindo para essas diferenças.

Observando-se as diferenças dos valores de temperatura máxima do ponto 3 do sistema consorciado e o cultivo a pleno sol (Tabela 9), outros componentes do balanço de energia parecem contribuir para valores superiores do ponto central do cultivo consorciado em relação ao cultivo a pleno sol, como o saldo de radiação, que nos meses de fevereiro, março e abril de 2002 (Figura 14) permaneceu próximo a igualdade entre esses pontos de amostragem, e ainda a incidência de vento, que foi significativamente menor no centro da parcela consorciada em relação aos outros pontos amostrais, principalmente no outono, quando se detectou diferenças estatísticas, conforme apresentado na Tabela 8. 

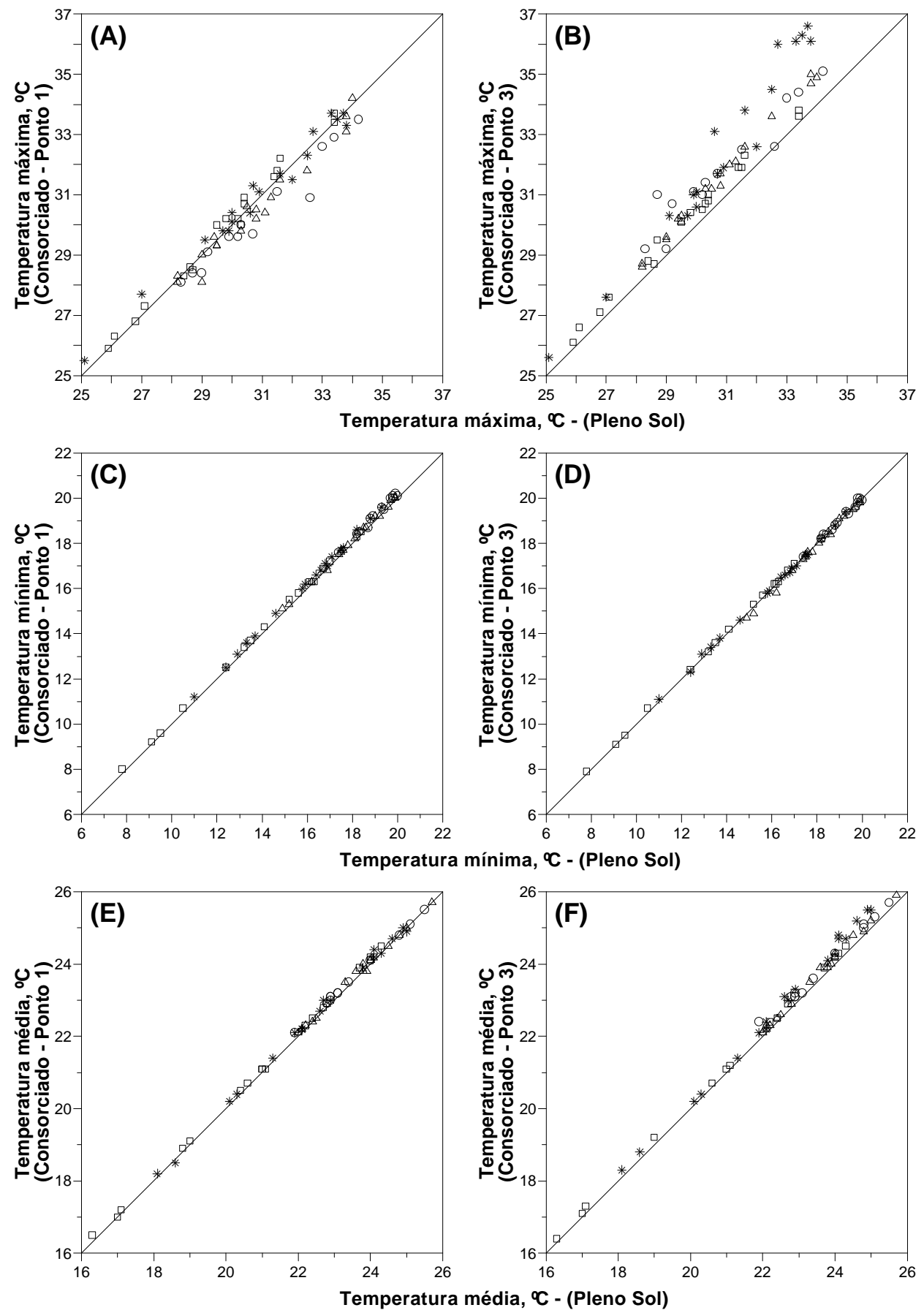

$\triangle$ Primavera $\bigcirc$ Verão $*$ Outono $\square$ Inverno

Figura 20 - Comparação entre os valores quinquidiais de temperatura máxima (A e B), temperatura mínima ( $C$ e D) e temperatura média ( $E$ e F) do ar em cultivos de café a pleno sol e em diferentes pontos amostrais de cultivo café consorciado com bananeira 'Prata Anã', para quatro estações do ano, em Mococa, SP 
Brenner (1996) relata que, em condições de cultivos protegidos por renques ou quebra-ventos, onde a incidência de radiação é semelhante a cultivos desprotegidos, as temperaturas diurnas são superiores, devido a menor movimentação do ar atmosférico, o que altera o balanço de energia, aumentando o fluxo de calor sensível. Temperaturas diurnas superiores em cultivos protegidos com quebra-ventos, quando a incidência de radiação solar é semelhante a cultivos não protegidos, também foram obtidas por Brown \& Rosemberg (1972), Ujah \& Adeoye (1984), ambos em cultivos protegidos por quebraventos artificiais, e Pezzopane et al. (2003a), em um sistema de produção de café consorciado com coqueiro-anão verde.

Para melhor representação da sazonalidade das diferenças da temperatura máxima do ar entre os pontos amostrais dos dois sistemas de cultivo, além do efeito de outros elementos em seu comportamento, foram selecionados quatro episódios (Figura 21) sob condição ensolarada, durante o período amostral.
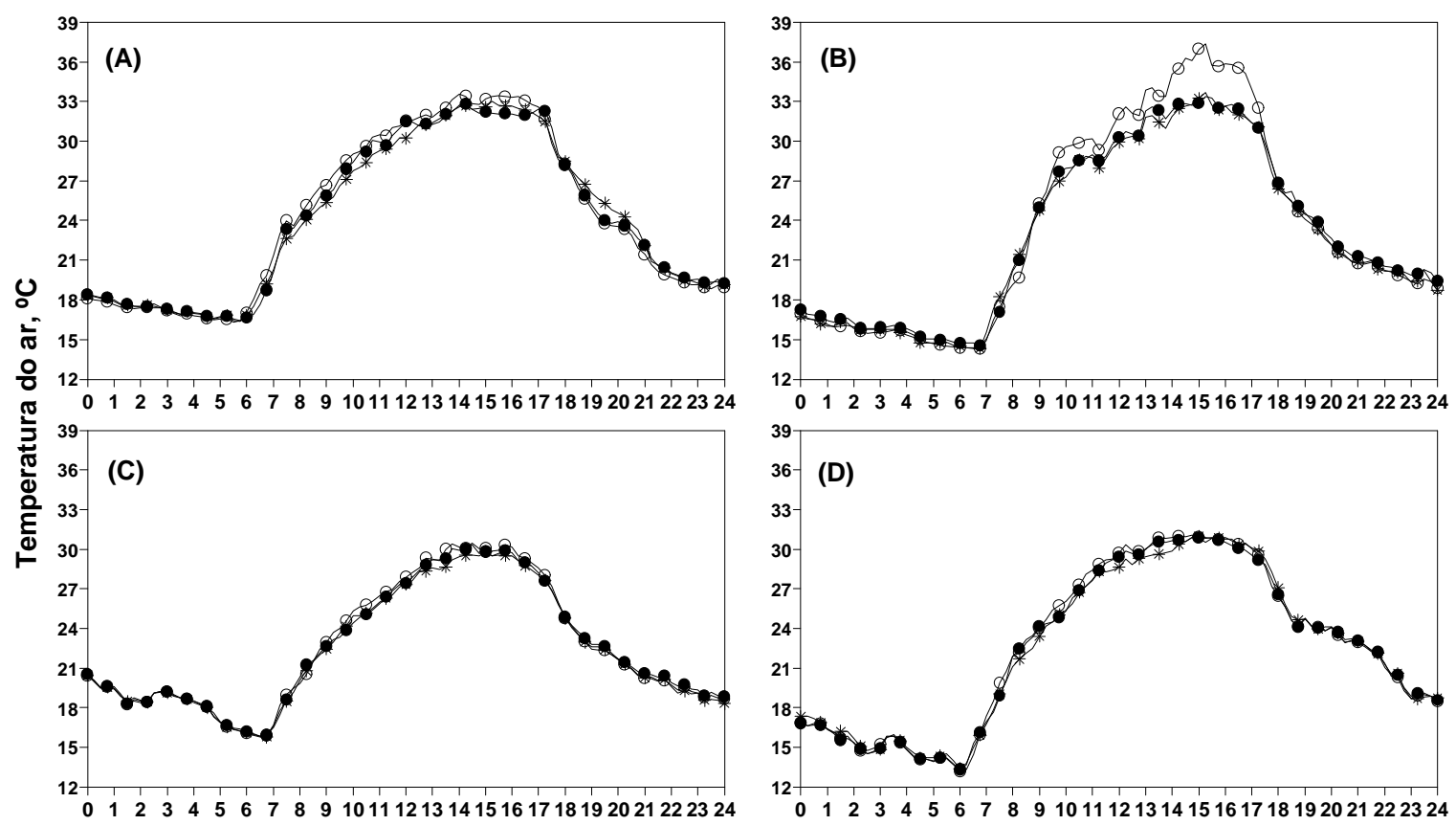

Hora do dia

* Pleno sol - Consorciado - Ponto $1-\odot$ Consorciado Ponto 3

Figura 21 - Variação dos valores horários da temperatura do ar em cultivo de café a pleno sol e consorciado com banana 'Prata Anã', em Mococa, SP, nos dias 6/11/2001 (A), 16/4/2002 (B), 18/8/2002 (C) e 27/9/2002 (D) 
No dia 6/11/2001 (Figura 21A), a temperatura máxima do ar foi 33,4, 33,1 e $33,9^{\circ} \mathrm{C}$ no cultivo a pleno sol e nos pontos amostrais 1 e 3 do cultivo consorciado, respectivamente. Para todo o período diurno a média da velocidade do vento foi de 1,4 , 0,74 e 0,60 m.s $\mathrm{s}^{-1}$ no cultivo a pleno sol e nos ponto amostrais 1 e 3 do cultivo consorciado, respectivamente. No dia 16/4/2002, a temperatura máxima do ar foi $32,1,32,8$ e $35,8^{\circ} \mathrm{C}$ no cultivo a pleno sol e nos ponto amostrais 1 e 3 do cultivo consorciado, respectivamente (Figura 21B). Para todo o período diurno a média da velocidade do vento foi de 1,5, 1,0 e $0,87 \mathrm{~m} / \mathrm{s}$ no cultivo a pleno sol e nos ponto amostrais 1 e 3 do cultivo consorciado, respectivamente.

A incidência da radiação solar global no ponto de amostragem 3 do sistema consorciado foi semelhante ao cultivo a pleno sol, enquanto que no ponto amostral 1 ocorreu atenuação na transmissividade a partir das 11 horas para esses dois episódios (Figura 12B).

A variação horária dos valores de temperatura diurna, e consequentemente, temperatura máxima, superiores no ponto amostral 3 do sistema consorciado em relação ao sistema de cultivo a pleno sol para os dias 6/11/2001 e 16/4/2002, está associado a incidência de radiação solar global equivalente no período da tarde, e a redução da ocorrência de vento ocorrida entre esses pontos amostrais. Outro fator que pode ter influenciado no aumento da diferença das máximas entre esses pontos amostrais no episódio de 16/4/2002 em relação ao episódio de 6/11/2001, foi o acentuado período seco (Figura 10A), fazendo com que aumentasse o fluxo de calor sensível, elevando assim, a temperatura do ar e por conseqüência as diferenças entre os pontos amostrais. Quando observados os dados de temperatura máxima do posto meteorológico, situado próximo ao experimento, verifica-se que no mês de abril de 2002, a temperatura média permaneceu cerca de 2,0ำ acima dos valores normais para o período (Anexo B).

No dia 18/8/2002 (Figura 21C), a temperatura máxima do ar foi 30,2, 30,6 e $30,9^{\circ} \mathrm{C}$ no cultivo a pleno sol e nos ponto amostrais 1 e 3 do cultivo consorciado, respectivamente. As plantas de bananeira utilizadas no consórcio promoveram redução de cerca de 30 a $40 \%$ da velocidade do vento, sendo que para todo o período diurno a média da velocidade do vento foi de 2,5, 1,76 e 1,52 m.s ${ }^{-1}$ no cultivo a pleno sol e nos ponto amostrais 1 e 3 do cultivo consorciado, respectivamente.

No dia 27/9/2002, a temperatura máxima do ar foi 31,3, 31,1 e 31,3ํㅡ no cultivo a pleno sol e nos ponto amostrais 1 e 3 do cultivo consorciado, respectivamente (Figura 
21D). A incidência da radiação solar global no ponto amostral 3 do sistema consorciado sofreu pequena atenuação em relação ao cultivo a pleno sol no período da tarde, enquanto que no ponto amostral 1 ocorreu atenuação na transmissividade a partir das 10 horas. As plantas de bananeira utilizadas no consórcio promoveram redução de cerca de $30 \%$ da velocidade do vento no período da tarde, sendo que para todo o período diurno a média da velocidade do vento foi de $1,32,0,88$ e $0,84 \mathrm{~m} \cdot \mathrm{s}^{-1}$ no cultivo a pleno sol e nos ponto amostrais 1 e 3 do cultivo consorciado, respectivamente.

A variação horária dos valores de temperatura diurna, e consequentemente, temperatura máxima, com valores próximos entre os pontos de amostragem, evidenciam a influência de outros elementos na temperatura do ar em sistemas consorciados. No dia $18 / 8 / 2002$, a velocidade do vento foi elevada em todos os pontos amostrais, com valor médio diurno de 2,5 m.s $\mathrm{s}^{-1}$ no sistema a pleno sol. Embora tenha ocorrido uma redução da velocidade do vento no sistema consorciado, os valores elevados provocaram homogeneização do ar sobre a cultura, fazendo com que as diferenças entre os pontos amostrais não fossem intensas, apesar do período seco verificado na região (Figura 10A).

Para o episódio de 27/9/2002, um importante fator que influenciou os valores de temperatura, foi a ocorrência de chuvas nos dias anteriores, que alterou o balanço hídrico no último decêndio do mês de setembro (Figura 10A), mudando o comportamento do balanço de energia, aumentando o fluxo de calor latente em relação ao de calor sensível, resultando em efeitos na temperatura do ar.

Quando analisados os dados de temperatura mínima do ar, em médias por estação do ano (Tabela 9) ou a dispersão, por estação do ano, dos valores quinquidiais (Figura 20C e 20D), pode-se verificar que não houve diferença significativa, pelo teste $t$, entre os pontos amostrais.

Embora tenham sido verificadas diferenças no saldo de radiação, para o período noturno, entre o ponto 1 do sistema consorciado (Figura 15 e Tabela 5) e os outros pontos de amostragem, resultante da contra-radiação noturna emitida pelas bananeiras, as diferenças na temperatura mínima do ar não foram significativas, sendo que o ponto 1 do sistema consorciado apresentou valores ligeiramente superiores ao cultivo a pleno sol $(0,1$ a $\left.0,3^{\circ} \mathrm{C}\right)$ e ao ponto 3 do sistema consorciado $\left(0,2\right.$ a $\left.0,3^{\circ} \mathrm{C}\right)$, dependendo da época do ano. Quando analisadas as médias anuais, o ponto 3 do sistema consorciado e o cultivo a pleno sol apresentaram os mesmos valores $\left(16,8^{\circ} \mathrm{C}\right)$, ligeiramente inferiores ao ponto 1 do sistema consorciado $\left(17,0^{\circ} \mathrm{C}\right)$. 
Analisando a evolução diária da temperatura do ar nos quatro episódios selecionados (Figura 21) foi observada, para os valores de temperatura mínima do ar, a mesma tendência ao se analisar os dados estacionais, com diferenças não superiores a $0,1^{\circ} \mathrm{C}$ entre os pontos amostrais do sistema consorciado e o cultivo a pleno sol.

Com relação a temperatura média do ar observada nos diferentes pontos de amostragem, tomando como base todas as estações do ano analisadas (Tabela 9 e Figura 20E e 20F), pode se verificar que não houve diferença significativa entre os sistemas de produção, embora tenham sido verificadas médias superiores em 0,1 a $0,3^{\circ} \mathrm{C}$ no ponto de amostragem 3 do sistema consorciado em relação ao cultivo a pleno sol e 0,1 a $0,2^{\circ} \mathrm{C}$ em relação ao ponto de amostragem 1 do sistema consorciado. Analisando a média anual, no cultivo a pleno sol, a temperatura foi de $22,7^{\circ} \mathrm{C}$, enquanto que no cultivo consorciado foi de 22,8 e 23,0ำ respectivamente, nos ponto de amostragem 1 e 3 do sistema consorciado.

Miguel et al. (1995), em um sistema arborizado de café com grevílea, com quatro anos de idade, em Varginha, MG, obtiveram média anual da temperatura média do ar semelhantes no sistema arborizado $\left(23,3^{\circ} \mathrm{C}\right)$ em relação ao cultivo a pleno sol $\left(23,2^{\circ} \mathrm{C}\right)$. Quando o sistema estava com catorze anos, os mesmos autores obtiveram valores inferiores de temperatura média do ar no sistema arborizado $\left(21,9^{\circ} \mathrm{C}\right)$ em relação ao monocultivo $\left(23,5^{\circ} \mathrm{C}\right)$, evidenciando a influência do porte das árvores nas condições microclimáticas dos cultivos, semelhante ao encontrado com Barradas \& Fanjul (1986), no México.

\subsubsection{Umidade do ar}

Assim como a temperatura média do ar, notou-se que a umidade relativa não variou quando comparados o cultivo de café a pleno sol e o cultivo consorciado (nos dois pontos amostrais). Considerando todo o período de amostragem a média da umidade relativa foi $69 \%$ para todos os pontos amostrais (Tabela 10). Na Figura 22, é apresentada a dispersão, por estação do ano, das médias quinqüidiais da umidade relativa, entre o cultivo a pleno sol e o consorciado, onde a mesma tendência pode ser observada. 
Tabela 10. Médias da umidade relativa do ar (\%), défice de saturação $(\mathrm{kPa})$ e pressão atual de vapor $(\mathrm{kPa})$ e valores do teste t de comparação de médias, em cultivo de café a pleno sol e em diferentes pontos amostrais de cultivo café consorciado com bananeira 'Prata Anã', em Mococa, SP, avaliadas em quatro estações do ano

\begin{tabular}{|c|c|c|c|c|c|c|}
\hline \multirow{2}{*}{ Época } & \multirow{2}{*}{ Pleno sol } & \multicolumn{2}{|c|}{ Consorciado } & \multicolumn{3}{|c|}{ Valor de $\mathrm{t}$} \\
\hline & & P1 & P3 & Pleno sol-P1 & Pleno sol - P3 & P1-P3 \\
\hline & \multicolumn{6}{|c|}{ Umidade relativa do ar (\%) } \\
\hline Primavera & 71,0 & 70,2 & 72,0 & $0,39^{\text {ns }}$ & $0,55^{\mathrm{ns}}$ & $0,95^{\mathrm{ns}}$ \\
\hline Verão & 78,5 & 78,0 & 78,3 & $0,35^{\text {ns }}$ & $0,12^{\text {ns }}$ & $0,22^{\text {ns }}$ \\
\hline Outono & & 69,1 & 67,0 & $0,54^{\mathrm{ns}}$ & $1,19^{\text {ns }}$ & $1,72^{\text {ns }}$ \\
\hline \multirow[t]{2}{*}{ Inverno } & & 58,4 & 57,3 & $0,18^{\text {ns }}$ & $0,54^{\text {ns }}$ & $0,72^{\text {ns }}$ \\
\hline & \multicolumn{6}{|c|}{ Défice de saturação $(\mathrm{kPa})$} \\
\hline Primavera & 1,01 & 1,01 & 1,03 & $0,25^{\text {ns }}$ & $0,26^{\mathrm{ns}}$ & $0,26^{\text {ns }}$ \\
\hline Verão & & 0,80 & 0,84 & 0,0 & $0,75^{\text {ns }}$ & $0,77^{\text {ns }}$ \\
\hline Outono & & 1,05 & 1,17 & $0,25^{\text {ns }}$ & 2,24 * & $2,45^{* *}$ \\
\hline \multirow{2}{*}{ Inverno } & 1,26 & 1,26 & 1,32 & $0,01^{\text {ns }}$ & $0,87^{\text {ns }}$ & $0,88^{\text {ns }}$ \\
\hline & \multicolumn{6}{|c|}{ Pressão atual de vapor (kPa) } \\
\hline Primavera & 1,98 & 2,02 & 1,97 & $0,24^{\text {ns }}$ & $1,23^{\text {ns }}$ & $1,47^{\text {ns }}$ \\
\hline Verão & & 2,28 & 2,30 & & & $1,74^{\mathrm{ns}}$ \\
\hline Outono & 1,7 & 1,80 & 1,77 & $0,68^{\mathrm{ns}}$ & $0,02^{\mathrm{ns}}$ & $0,66^{\mathrm{ns}}$ \\
\hline Inverno & 1,38 & 1,40 & 1,37 & $0,45^{\mathrm{ns}}$ & $0,27^{\text {ns }}$ & $0,43^{\text {ns }}$ \\
\hline
\end{tabular}

Também foi notada uma sazonalidade da umidade relativa, assim como nos casos da radiação solar e da temperatura. As maiores médias foram observadas no período de verão (cerca de $78 \%$ ), sendo que a partir dos meses de outono e inverno, quando foi observada a ausência de chuvas significativas na área experimental (Figura 10), foram observadas os menores valores médios (cerca de 58\%).

Outras maneiras de expressar o teor de água na atmosfera são a pressão atual de vapor e o défice de pressão de vapor (DPV), definido como a diferença entre a pressão de saturação e a pressão atual de vapor atmosférico. Como a capacidade máxima da atmosfera de reter vapor, ou seja, a pressão de saturação, é determinada pela temperatura do ar, em uma relação exponencial, pode-se explicar, em parte, o comportamento da umidade relativa ou mesmo do DPV em função desta variável (Vianello \& Alves, 1991). 

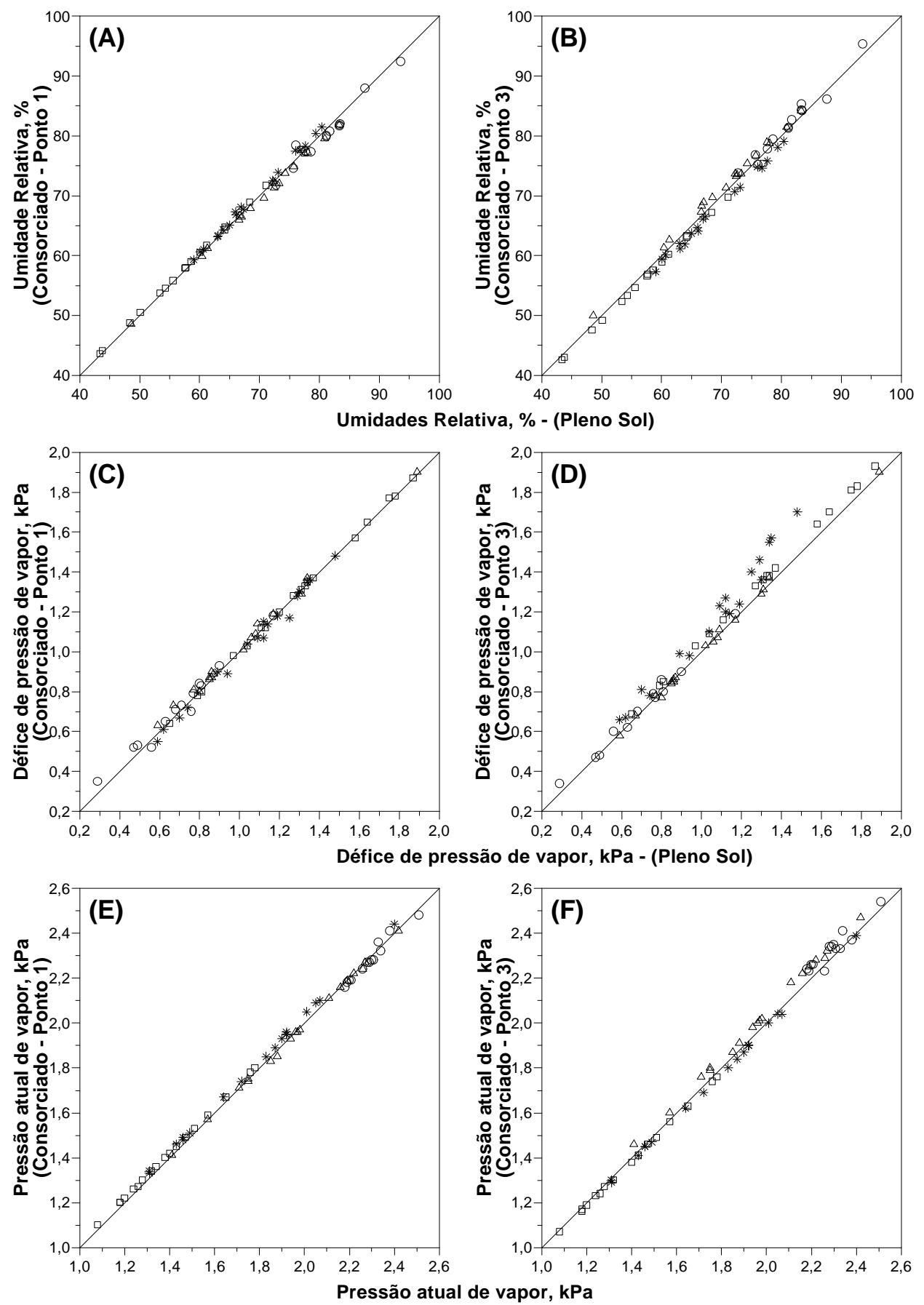

$\triangle$ Primavera $\bigcirc$ Verão $*$ Outono $\quad \square \quad$ Inverno

Figura 22 - Comparação entre os valores quinqüidiais da umidade relativa ( $A$ e $B$ ), défice de pressão de vapor ( $C$ e D) e pressão atual de vapor ( $E$ e $F)$ do ar em cultivos de café a pleno sol e em diferentes pontos amostrais de cultivo café consorciado com bananeira 'Prata Anã', para quatro estações do ano, em Mococa, SP 
Como pode ser verificado na Figura $22 \mathrm{~B}$, os valores de temperatura no período diurno, e consequentemente, os valores de temperatura máxima, para o período de outono, foram significativamente maiores no ponto de amostragem 3 do cultivo consorciado em relação ao cultivo a pleno sol. Em função disso foi observada uma mudança no comportamento da umidade relativa entre o ponto de amostragem 3 do sistema consorciado em relação ao cultivo a pleno sol durante os meses do outono e inverno, em relação ao período de primavera-verão, com valores superiores no cultivo a pleno sol (Figura 22A e 22B). Pelo mesmo motivo, os valores quinquidiais de DPV no ponto de amostragem 3 foram superiores ao cultivo a pleno sol (Figura 22D) no período de outono e inverno.

Para todo o período de amostragem, o DPV médio foi de 1,03 kPa para o cultivo a pleno sol, 1,03 e 1,08 kPa para o cultivo consorciado nos ponto de amostragem 1 e 3, respectivamente, sendo verificada diferenças estatísticas, pelo teste t, para o período de outono entre o ponto 3 do sistema consorciado e os outros pontos amostrais (Tabela 10).

Apesar da parcela consorciada apresentar em seu ponto central de amostragem menores valores de umidade relativa e por conseqüência maiores valores de défice de saturação, quando são analisados os valores de pressão atual de vapor (Tabela $10 \mathrm{e}$ Figura 22E e 22F) essa tendência não é verificada, principalmente no período de verão e outono, quando que no ponto 3 de amostragem do sistema consorciado os valores permaneceram em igualdade ou foram superiores aos do cultivo a pleno sol, embora sem diferenças estatísticas significativas. Em cultivos protegidos por quebra-ventos vários autores observaram o mesmo comportamento, como foi o caso de Brow \& Rosemberg (1972), Ujah \& Adeoye (1984), entre outros, sendo que essa tendência é explicada pela redução da incidência de vento (Tabela 6), que diminui a quantidade de vapor no ar adjacente ao dossel das plantas. Ainda sobre o assunto, Brenner (1996) relata que o teor de umidade sobre a superfície de cultivos entre árvores esparsas é influenciado pelo tipo de vegetação e teor de umidade do solo.

Na Figura 23 é apresentada a variação da pressão atual de vapor (ea) nos pontos amostrais durante quatro episódios sob condição ensolarada. No dia 8/11/2001 (Figura 23A) a pressão atual de vapor no período diurno, foi sistematicamente superior no ponto amostral 3 da parcela consorciada em relação aos outros pontos de amostragem, efeito da redução da incidência de vento no centro da parcela consorciada. Para os outros episódios selecionados o comportamento da pressão atual de vapor foi semelhante para todos os 
pontos amostrais, assim como a variação estacional, como pode ser observada na Figura 22E e 22F e na Tabela 10.

Quando analisada a evolução da pressão atual de vapor para todos os pontos amostrais nos diferentes episódios selecionados, nota-se tendências distintas de variação ao longo dos dias amostrados. No dia 6/11/2001 (Figura 23A), em uma época úmida, foi verificada uma elevação de ea na parte da manhã, atingindo níveis de 2,3 kPa, com redução no período da tarde, com um comportamento semelhante ao encontrado por Angelocci (1996) em um pomar de macieiras e por Marin (2003) em um cafezal cultivado em renque. Segundo esses autores, esse efeito está associado a abertura estomática, mais intensa no período da manhã, com conseqüente incremento da quantidade de vapor d'água na atmosfera, o que começa a declinar no período da tarde. Essa tendência já foi menos significativa no dia 16/4/2002 (Figura 23B), quando os níveis de ea sofreram um pequeno declínio às 10 horas e no final da tarde atingiram valores mínimos próximos a 1,2 kPa. É bom ressaltar que em abril de 2002 a região onde se encontra o experimento já estava sob forte condição de seca.

Já a redução da pressão atual de vapor ao longo do dia 18/8/2002 (Figura 23C), atingindo valores próximos a $1,0 \mathrm{kPa}$ no final da tarde, está relacionada a ação de uma massa de ar frio e seco que estava atuando sobre a região. A incidência de vento sobre os cultivos, com valor médio de $2,5 \mathrm{~m} / \mathrm{s}$ no período diurno para o cultivo a pleno sol contribuiu para a diminuição da quantidade de vapor d'água sobre a superfície. No dia 27/9/2002 (Figura 23D), embora os valores de ea ao longo do dia ainda fossem baixos (valor máximo de 1,6kPa), sua elevação no período da manhã foi ocasionada pela ocorrência de chuvas nos dias anteriores, o que proporcionou uma elevação no incremento da quantidade de vapor d'água na atmosfera. 

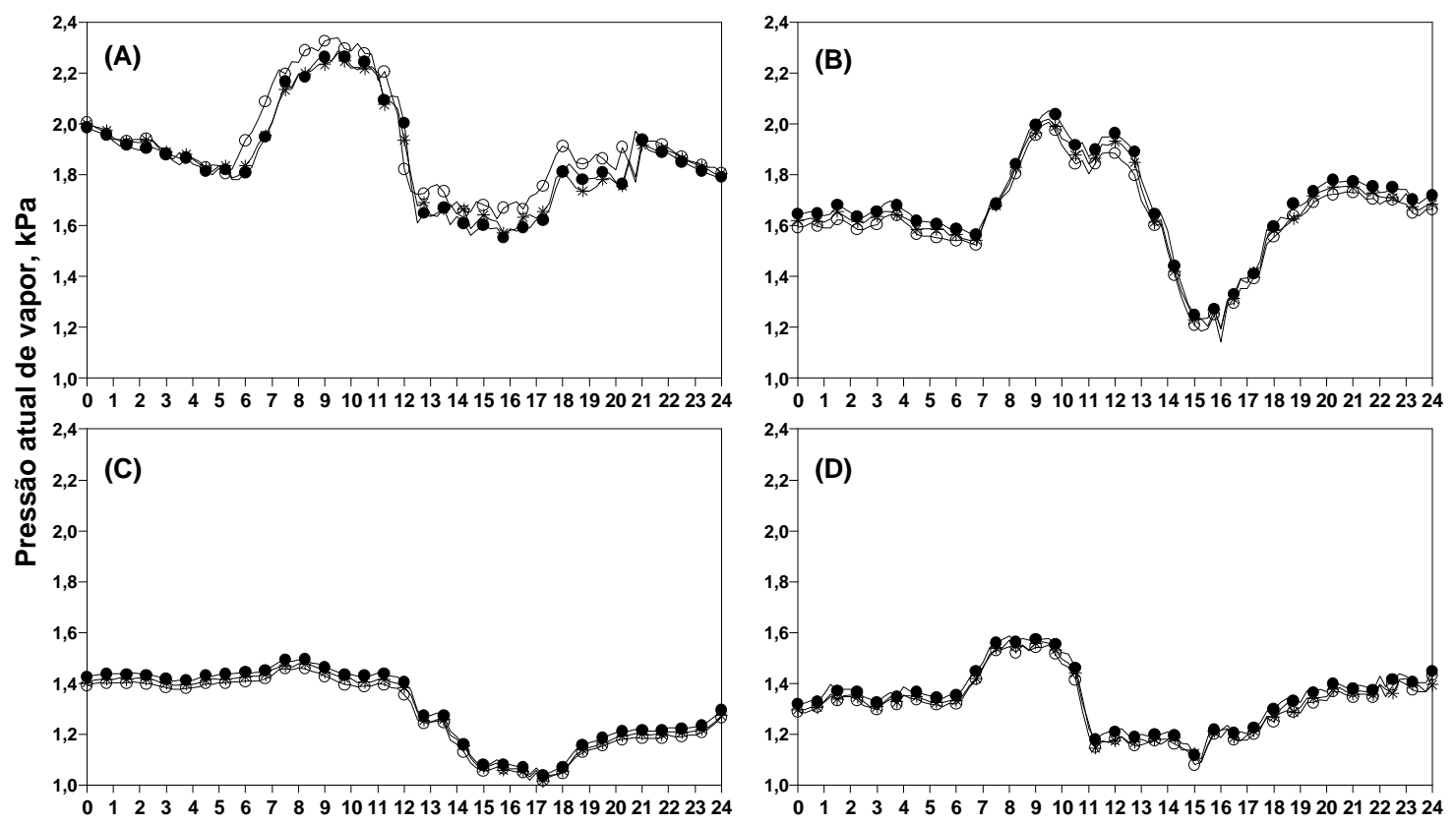

Hora do dia

Pleno sol - Consorciado - Ponto $1-\odot$ Consorciado Ponto 3

Figura 23 - Variação dos valores horários da pressão atual de vapor em cultivo de café a pleno sol e em diferentes pontos amostrais de cultivo de café consorciado com banana 'Prata Anã', em Mococa, SP, nos dias 6/11/2001 (A), 16/4/2002 (B), 18/08/2002 (C) e 27/9/2002 (D)

\subsection{Análise microclimática durante episódios de resfriamento do ar}

O período de inverno do ano de 2002 foi caracterizado por poucos dias com resfriamento intenso. A temperatura mínima absoluta observada no posto meteorológico de primeira classe, situado perto do experimento foi de $4,4^{\circ} \mathrm{C}$, ocorrida no dia 9 de julho. Para caracterizar o efeito das plantas de banana nas condições microclimáticas dos cultivos durante o período que envolveu esse episódio de resfriamento, foram selecionados os dados obtidos nos dias 8 a 10 de julho, que estão apresentados na Tabela 11 e na Figura 24. 
Tabela 11. Valores diários de temperatura do ar e folha $\left({ }^{\circ} \mathrm{C}\right)$ e do saldo de radiação $\left(M J \cdot \mathrm{m}^{-2}\right)$ em cultivo de café a pleno sol e em diferentes pontos amostrais de cultivo de café consorciado com bananeira 'Prata Anã', em Mococa, SP, durante o período de 8 a 10 de julho de 2002

\begin{tabular}{|c|c|c|c|c|c|c|c|c|}
\hline \multirow[t]{2}{*}{ Dia } & \multirow{2}{*}{$\begin{array}{l}\text { Ponto de } \\
\text { leitura* }\end{array}$} & \multicolumn{2}{|c|}{$\begin{array}{l}\text { Temperatura } \\
\text { do } \operatorname{ar}\left({ }^{\circ} \mathrm{C}\right)\end{array}$} & \multicolumn{2}{|c|}{$\begin{array}{l}\text { Temperatura } \\
\text { da folha }\left({ }^{\circ} \mathrm{C}\right)\end{array}$} & \multicolumn{3}{|c|}{ Saldo de radiação $\left(\mathrm{MJ} \cdot \mathrm{m}^{-2}\right)^{* *}$} \\
\hline & & Mínima & Máxima & Mínima & Máxima & Diurno & Noturno & Total \\
\hline \multirow{4}{*}{$8 / 7$} & Sol & 6,0 & 22,1 & 4,1 & 26,0 & 7,64 & $-2,56$ & 5,08 \\
\hline & P1 & 6,2 & 23,0 & 5,0 & 22,1 & 0,74 & $-0,65$ & 0,09 \\
\hline & P2 & 6,1 & 22,5 & 4,6 & 22,6 & - & - & - \\
\hline & P3 & 6,0 & 22,2 & 4,6 & 27,2 & 7,01 & $-1,57$ & 5,44 \\
\hline \multirow{4}{*}{$9 / 7$} & Sol & 3,0 & 26,7 & 1,1 & 31,2 & 8,00 & $-3,05$ & 4,95 \\
\hline & P1 & 3,3 & 26,5 & 1,6 & 25,9 & 0,34 & $-0,78$ & $-0,44$ \\
\hline & P2 & 3,1 & 26,3 & 1,2 & 25,7 & - & - & \\
\hline & P3 & 3,0 & 26,8 & 1,4 & 31,4 & 8,22 & $-1,98$ & 6,24 \\
\hline \multirow{4}{*}{$10 / 7$} & Sol & 5,8 & 28,5 & 3,8 & 33,9 & 6,05 & $-2,24$ & 3,81 \\
\hline & P1 & 6,1 & 28,7 & 4,5 & 27,9 & 1,36 & $-0,52$ & 0,84 \\
\hline & P2 & 5,8 & 28,8 & 3,8 & 29,1 & - & - & - \\
\hline & P3 & 5,8 & 29,1 & 4,1 & 31,5 & 7,18 & $-1,52$ & 5,66 \\
\hline
\end{tabular}

* Ponto de leitura: Sol: Café a pleno sol; P1: Ponto de amostragem 1 do sistema consorciado; P2: Ponto de amostragem 2 do sistema consorciado; P3: Ponto de amostragem 3 do sistema consorciado

** Saldo de radiação: Diurno: entre 6 e 18 horas; Noturno: entre 18 e 6 horas; Total: total diário

No dia 9/7/2002, a temperatura mínima do ar no cultivo a pleno sol foi de $3,0^{\circ} \mathrm{C}$, enquanto que no cultivo consorciado foi de $3,3^{\circ} \mathrm{C}$ (Tar em P1 - Embaixo da bananeira) e $3,1^{\circ} \mathrm{C}$ e $3,0^{\circ} \mathrm{C}$ nas posições adjacentes, entre duas bananeiras. Com relação a temperatura mínima das folhas dos cafeeiros, em seu terço superior, os valores foram um pouco mais baixos, sendo $1,1^{\circ} \mathrm{C}$ no cultivo a pleno sol, 1,6ำ (TF em P1 - Embaixo da bananeira) e 1,2 e 1,4 $4^{\circ} \mathrm{C}$ nas posições adjacentes. É importante ressaltar que a ocorrência de vento na madrugada (Figura 24D) provocou uma homogeneização do ar, fazendo com que as diferenças entre os valores de temperatura mínima foliar fossem baixas, embora tenha ocorrido menor perda de radiação no cultivo consorciado (Tabela 11 e Figura 24C). Os valores de temperatura mínima foliar neste episódio, que foi o mais frio do ano, para todos os pontos analisados permaneceram bem acima do ponto letal para o cafeeiro, que é cerca de $-3 a-4^{\circ} \mathrm{C}$ (Sentelhas et al., 1995). 

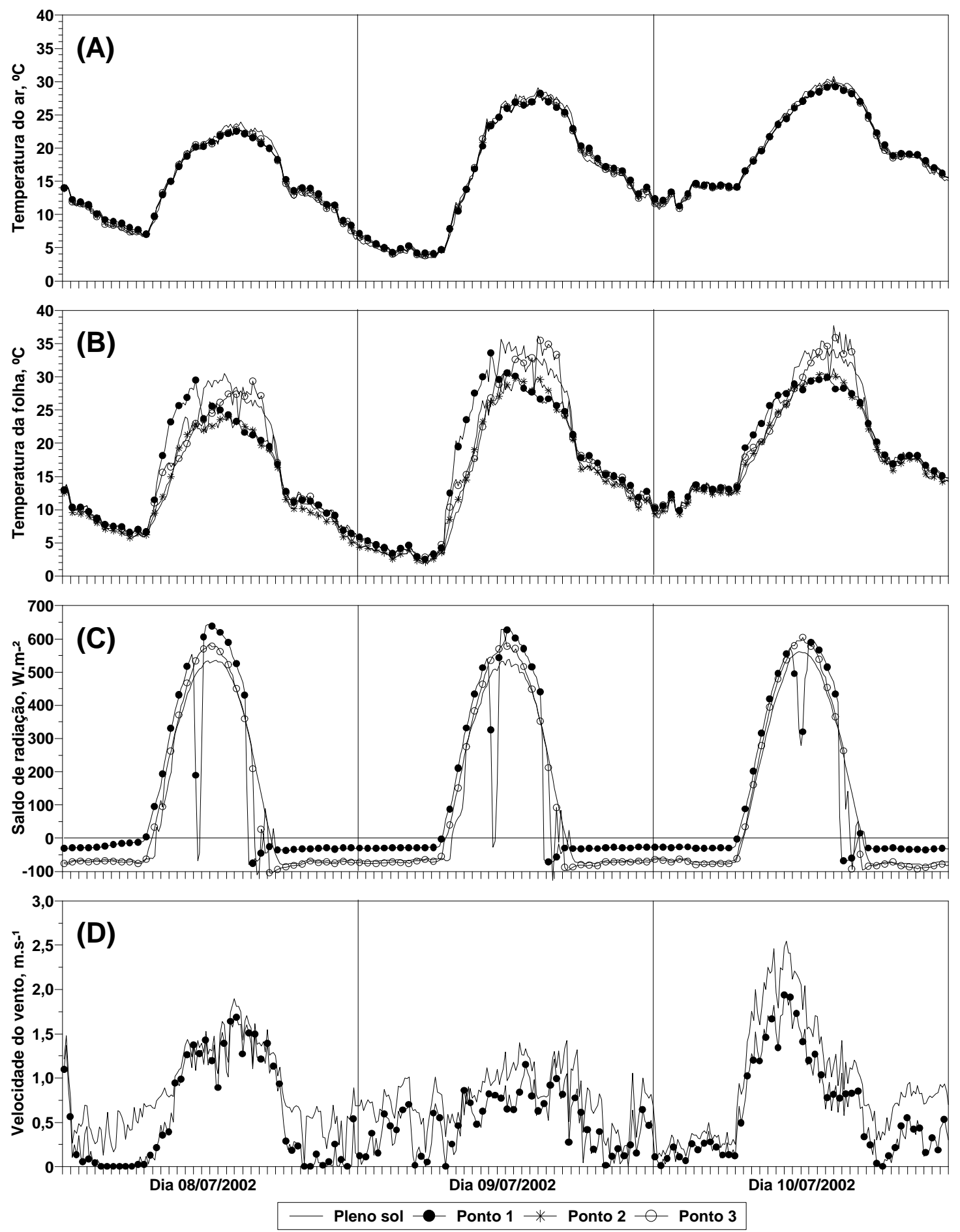

Figura 24 - Temperatura do ar $(A)$, temperatura da folha $(B)$, saldo de radiação $(C)$ e velocidade do vento (D) em cultivo de café a pleno sol e em diferentes pontos amostrais de cultivo de café consorciado com banana 'Prata Anã', nos dias 8 a 10 de julho de 2002, em Mococa, SP 
Assim como o período de inverno de 2002, também o ano de 2003 foi caracterizado por poucos dias com resfriamento mais intenso, sendo que a temperatura mínima absoluta observada no posto meteorológico de primeira classe, situado próximo do experimento foi de $4,6^{\circ} \mathrm{C}$, ocorrida no 18 de agosto, sendo selecionado o período de 17 a 19 de agosto para caracterizar o efeito das plantas de banana nas condições microclimáticas dos cultivos (Tabela 12 e na Figura 25).

Tabela 12. Valores diários de temperatura do ar e folha $\left({ }^{\circ} \mathrm{C}\right)$ e do saldo de radiação $\left(M J \cdot \mathrm{m}^{-2}\right)$ em cultivo de café a pleno sol e em diferentes pontos amostrais de cultivo de café consorciado com bananeira 'Prata Anã', em Mococa, SP, durante o período de 17 a 19 de agosto de 2003

\begin{tabular}{|c|c|c|c|c|c|c|c|c|}
\hline \multirow[t]{2}{*}{ Dia } & \multirow{2}{*}{$\begin{array}{l}\text { Ponto de } \\
\text { leitura* }\end{array}$} & \multicolumn{2}{|c|}{$\begin{array}{c}\text { Temperatura } \\
\text { do } \operatorname{ar}\left({ }^{\circ} \mathrm{C}\right)\end{array}$} & \multicolumn{2}{|c|}{$\begin{array}{l}\text { Temperatura } \\
\text { da folha }\left({ }^{\circ} \mathrm{C}\right)\end{array}$} & \multicolumn{3}{|c|}{ Saldo de radiação $\left(\mathrm{MJ} \cdot \mathrm{m}^{-2}\right)^{* *}$} \\
\hline & & Mínima & Máxima & Mínima & Máxima & Diurno & Noturno & Total \\
\hline \multirow{4}{*}{$17 / 8$} & Sol & 6,2 & 24,4 & 4,3 & 32,4 & 11,12 & $-2,97$ & 8,15 \\
\hline & P1 & 6,6 & 23,2 & 4,8 & 31,5 & 11,35 & $-1,23$ & 10,13 \\
\hline & P2 & 6,4 & 23,4 & 4,7 & 30,7 & & & \\
\hline & P3 & 6,4 & 23,4 & 4,7 & 33,4 & 11,21 & $-3,20$ & 8,01 \\
\hline \multirow{4}{*}{$18 / 8$} & Sol & 3,2 & 29,5 & 2,0 & 38,4 & 10,98 & $-2,95$ & 8,04 \\
\hline & P1 & 3,4 & 29,1 & 2,4 & 36,2 & 11,29 & $-1,30$ & 10,00 \\
\hline & P2 & 3,3 & 29,0 & 2,1 & 33,5 & - & - & - \\
\hline & P3 & 3,3 & 28,8 & 2,1 & 39,7 & 11,46 & $-3,20$ & 8,26 \\
\hline \multirow{4}{*}{$19 / 8$} & Sol & 10,6 & 31,3 & 8,7 & 37,8 & 11,68 & $-3,11$ & 8,57 \\
\hline & P1 & 10,8 & 30,9 & 8,8 & 32,5 & 11,63 & $-1,34$ & 10,29 \\
\hline & P2 & 10,6 & 31,7 & 8,7 & 32,8 & - & - & - \\
\hline & P3 & 10,7 & 31,9 & 9,0 & 38,0 & 11,86 & $-3,38$ & 8,49 \\
\hline
\end{tabular}

* Ponto de leitura: Sol: Café a pleno sol; P1: Ponto de amostragem 1 do sistema consorciado; P2: Ponto de amostragem 2 do sistema consorciado; P3: Ponto de amostragem 3 do sistema consorciado

** Saldo de radiação: Diurno: entre 6 e 18 horas; Noturno: entre 18 e 6 horas; Total: total diário 

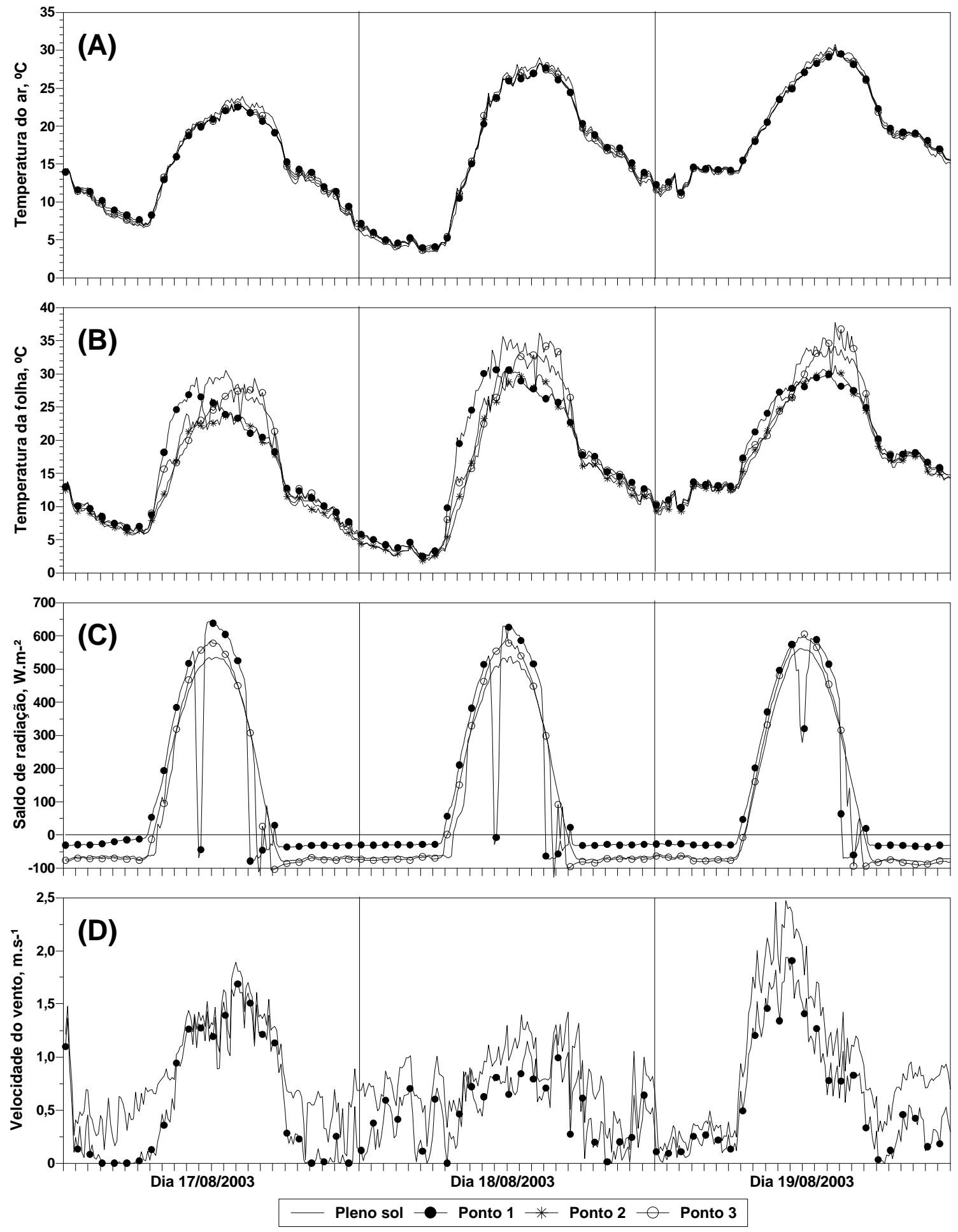

Figura 25 - Temperatura do ar (A), temperatura da folha (B), saldo de radiação (C) e velocidade do vento (D) em cultivo de café a pleno sol e em diferentes pontos amostrais de cultivo de café consorciado com banana 'Prata Anã', nos dias 17 a 19 de agosto de 2003, em Mococa, SP 
No dia $18 / 8 / 2003$, a temperatura mínima do ar no cultivo a pleno sol foi de $3,2^{\circ} \mathrm{C}$, enquanto que no cultivo consorciado foi de 3,4ำ (Tar em P1 - Embaixo da bananeira) e $3,3^{\circ} \mathrm{C}$ nas posições adjacentes, entre duas bananeiras. Com relação a temperatura mínima das folhas dos cafeeiros, em seu terço superior, os valores foram $2,0^{\circ} \mathrm{C}$ no cultivo a pleno sol, 2,4ํㅡ (TF em P1 - Embaixo da bananeira) e 2,1ํㅡ nas posições adjacentes.

As diferenças entre os valores mínimos absolutos de temperatura do ar e folhas entre o cultivo a pleno sol e o cultivo consorciado em seu ponto de leitura mais próximo das bananeiras, permaneceram próximos a 0,3 e $0,5^{\circ} \mathrm{C}$, respectivamente. Caramori et al. (1996), em estudos de cafeeiros com sombreamento mais intenso, com culturas como bracatinga (Mimosa scabrella), obtiveram diferenças de até $3^{\circ} \mathrm{C}$ para a temperatura do ar e $4^{\circ} \mathrm{C}$ para temperatura das folhas em eventos de geadas de radiação, valores semelhantes ao obtidos por Leuning \& Cremer (1988) para um cultivo de Eucalyptus $s p$.

A análise dos episódios nos anos de 2002 e 2003 mostra a influência do manejo do desbaste das bananeiras na ocorrência das condições microclimáticas no cultivo consorciado. As diferenças de temperatura mínima do ar e folhas entre o cultivo a pleno sol e consorciado e entre os pontos de leitura do sistema consorciado, embora tenham sido pequenas, foram mais significativas no ano de 2002 em relação ao ano de 2003. Isto também pode ser verificado quando se analisa a influência das bananeiras em parâmetros como o saldo de radiação e velocidade do vento (Figuras 24 e 25).

No episódio do ano de 2002, ocorreu menor perda de radiação para a atmosfera nos pontos amostrais $\mathrm{P} 1$ e P3 do cultivo consorciado em relação ao cultivo a pleno sol (Tabela 11), o mesmo não tendo sido verificado no ano de 2003, quando os valores noturnos do saldo de radiação no ponto 3 do sistema consorciado foram iguais ou superiores ao cultivo a pleno sol e os valores diurnos do saldo de radiação no ponto 1 foram iguais ou superiores ao cultivo a pleno sol (Figura 25C).

Analisando o comportamento dos valores diurnos de temperatura do ar e principalmente da folha durante o período diurno dos dias 8 a 10 de julho de 2003 (Tabela 12 e Figura 25B), pode se verificar a influência do manejo de desbaste das bananeiras e de outros elementos climáticos na temperatura de sistemas consorciados. No dia 18/8/2003, no período da manhã, o ponto amostral 1 do sistema consorciado apresentou maiores valores de saldo de radiação (Figura 25C), como conseqüência maiores valores de temperatura da folha (Figura 25B), com valor máximo de $36,2^{\circ} \mathrm{C}$, com comportamento semelhantes nos outros dias. No período entre 12-13 horas, com maior interceptação da 
radiação pelas bananeiras, a temperatura nesse ponto amostral caiu, se mantendo abaixo dos outros dois pontos amostrais. A interceptação da radiação no ponto amostral 1 do sistema consorciado nas horas centrais do dia, pode ser observada na Figura 25C, assim como ocorrido nos episódios do ano anterior (Figura 24C). Por outro lado, o ponto 3 (situado entre duas bananeiras), apresentou, no período central do dia valores mais elevados de saldo de radiação em relação ao cultivo a pleno sol, para todos os dias amostrados, provavelmente pela localização do sensor, que recebia contribuição de contra-radiação emitida pelas folhas das bananeiras, contribuindo para a obenção de valores mais elevados de temperatura foliar nesse dia $\left(39,7^{\circ} \mathrm{C}\right.$ contra $38,4^{\circ} \mathrm{C}$ do cultivo a pleno sol).

\subsection{Características aerodinâmicas e energéticas}

\subsubsection{Perfis de vento}

$\mathrm{Na}$ Figura 26, são apresentados os perfis médios da velocidade do vento no sistema de cultivo de café a pleno sol nos episódios amostrados nas quatro épocas do ano, caracterizados por diferentes regimes de velocidade de vento.
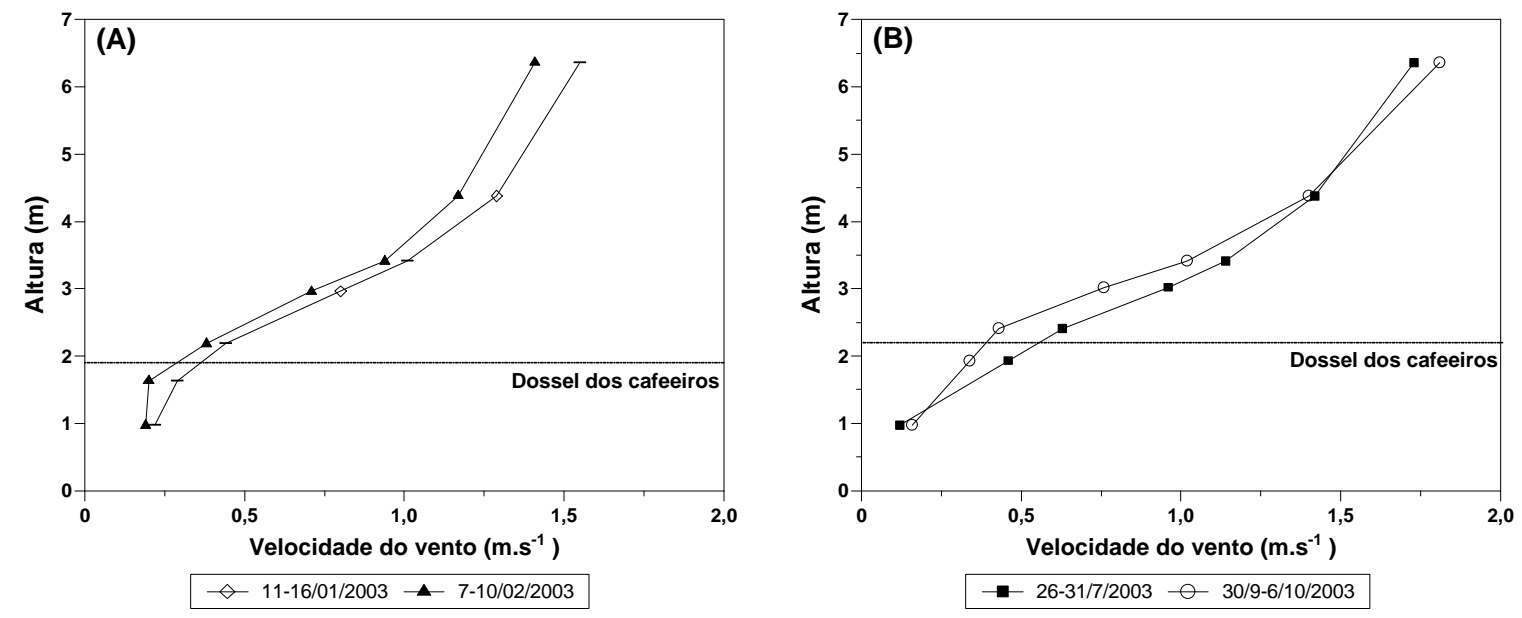

Figura 26 - Perfis médios da velocidade do vento $\left(\mathrm{m}^{-1} \mathrm{~s}^{-1}\right)$ no cultivo de café a pleno sol, durante os períodos de 11-16/1/2003 e 7-10/02/2002 (A) e 26-31/7/2003 e 30/9-6/10/2003 (B), em Mococa, SP 
Os períodos de amostragem de janeiro e fevereiro de 2003 apresentaram menores incidências de vento. Durante o período de 11 a 16 de janeiro de 2003, no posto meteorológico, situado próximo ao experimento, a velocidade média foi de 1,72 $\mathrm{m} . \mathrm{s}^{-1}$, enquanto no período de 7 a 10 de fevereiro a velocidade média foi de $1,81 \mathrm{~m}^{\mathrm{s}} \mathrm{s}^{-1}$. Os episódios de julho e outubro apresentaram maiores velocidades de vento, com médias de 2,13 e 2,29 m.s $\mathrm{s}^{-1}$, respectivamente para cada período.

Na Figura 27 são apresentados os perfis médios da velocidade do vento no cultivo a pleno sol, a cada duas horas, no período entre 4 e 18 horas, para os dias 10/2/2003 e 6/10/2003. O dia 10/2/203 apresentou velocidade média de 2,08 m.s. enquanto para o dia 6/10/2003, foi 2,5 m.s. ${ }^{-1}$, sendo que as diferenças foram mais evidentes no período da manhã. Comparando-se os dois dias, verifica-se que até a altura do dossel dos cafeeiros a velocidade do vento permaneceu praticamente constante para no dia 10/2/2003 (Figura 27A), influencia da direção do vento, que foi predominantemente perpendicular ao sentidos dos renques de café. No dia 3/10 (Figura 27B), com ventos paralelos aos renques, durante as primeiras horas do dias foi observado um acréscimo na velocidade a partir do segundo nível de medida.

Para os dois episódios apresentados, bem como para a média dos perfis durante os períodos de medida (Figura 26), verificou-se uma tendência dos perfis serem logarítmicos.

Na Figura 28 são apresentados os perfis médios da velocidade do vento no cultivo de café consorciado com banana 'Prata Anã' nos episódios amostrados em cinco épocas do ano, caracterizados por diferentes regimes de velocidade de vento. Os períodos de amostragem de novembro e março de 2003 apresentaram maior e menor incidência de vento, respectivamente. Durante o período de 5 a 10 de novembro de 2003, no posto meteorológico, a velocidade média de vento foi de $2,71 \mathrm{~m} \cdot \mathrm{s}^{-1}$, enquanto no período de $26 \mathrm{a}$ 30 de março a velocidade média foi de 1,69 $\mathrm{m}_{\mathrm{s}} \mathrm{s}^{-1}$. Os episódios de dezembro de 2002, abril e julho de 2003 apresentaram valores médios intermediários em relação aos dois primeiros apresentados. 
(A)

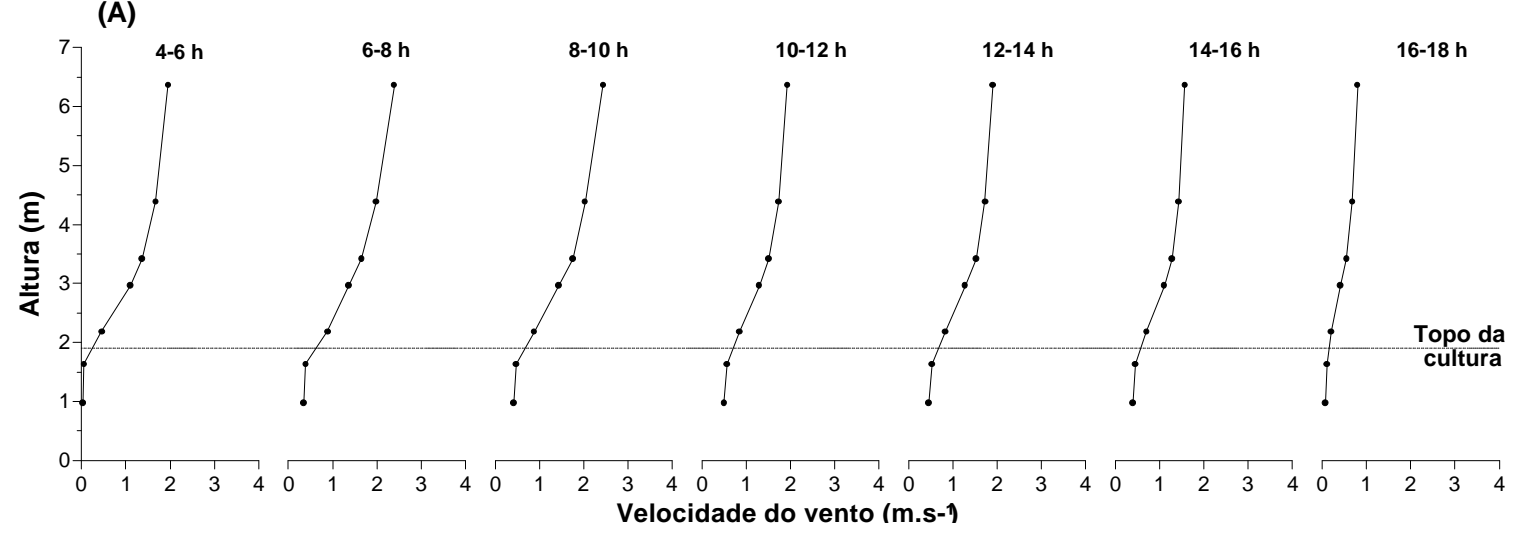

(B)

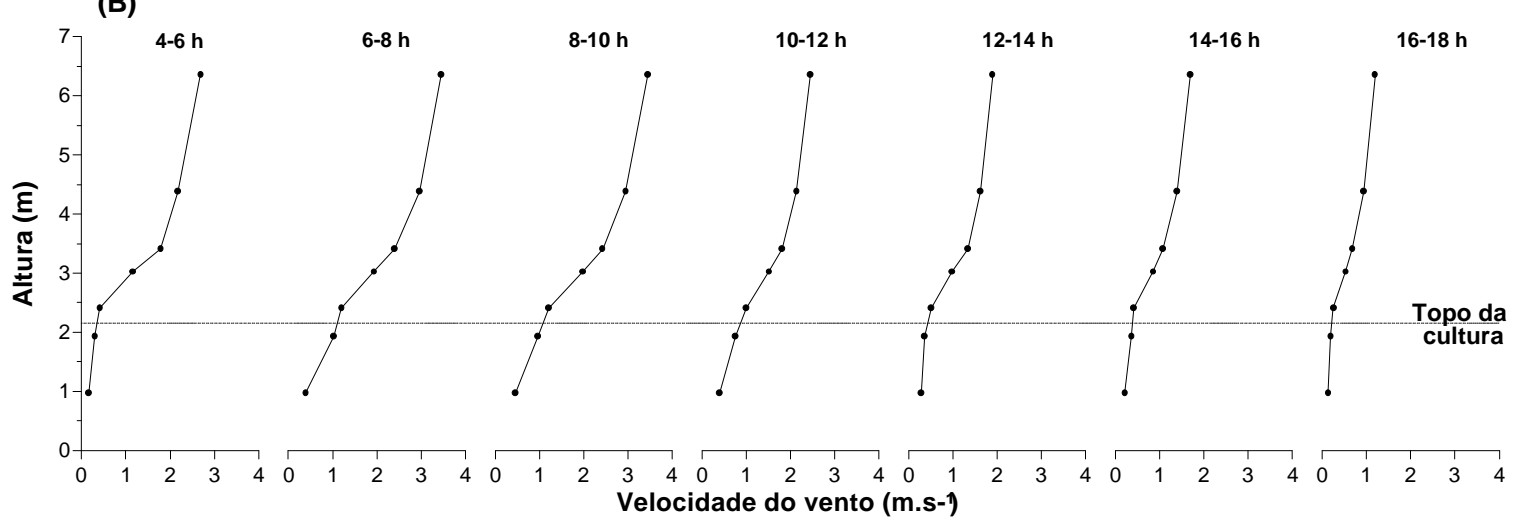

Figura 27 - Perfis médios da velocidade do vento $\left(\mathrm{m} . \mathrm{s}^{-1}\right)$, a cada duas horas, no cultivo de café a pleno sol, nos dias 10 de fevereiro (A) e 3 de outubro de 2003 (B), em Mococa, SP

No cultivo consorciado, as plantas de bananeira promoveram um deslocamento do perfil logarítmico acima do dossel das bananeiras (Figura 28), onde também se observa que a velocidade do vento no ponto mais baixo de amostragem (2 metros) nos dois últimos períodos se manteve próximo a $0,25 \mathrm{~m} . \mathrm{s}^{-1}$. Essa redução ocorreu devido ao crescimento das plantas de café, que a partir da amostragem de julho de 2003 estavam com um tamanho médio de 2,10 metros (Tabela 2).

$\mathrm{Na}$ Figura 28B são apresentados os perfis normalizados, isto é, quando as velocidades nos pontos amostrais (u) são transformadas em proporção da velocidade do vento no topo das plantas de bananeira $\left(u_{0}\right)$, sendo considerado $\mu_{0} 0$ anemômetro situado a 4,59 metros (z). Nessa situação os perfis se mostram similares no interior do dossel da bananeira, com velocidade do vento em torno de $75 \%$ com relação ao topo da cultura 
$(h / z=1)$. A exceção nesse comportamento foi o período amostral de 2 a 9 de julho de 2003, onde as plantas de bananeira promoveram menor redução da velocidade no interior do dossel das bananeiras (níveis 2 e 3), onde a relação u/uo permaneceu próxima à igualdade. Isto provavelmente ocorreu por ser esse um período de amostragem na época mais seca do ano, fazendo com que a área foliar do dossel das bananeiras fosse menor do que nas outras épocas de amostragem, interferindo menos no regime de vento sobre a cultura. Outro fator associado a esse comportamento foi o desbaste das bananeiras ocorrido no final do mês de abril de 2003.

Brenner (1996) relata que em cultivos agroflorestais ou com árvores espaçadas, os perfis não se comportam de forma logarítimica abaixo do nível das copas e que a relação $\mathrm{u} / \mathrm{u}_{0}$ aumenta com o maior espaçamento ou enfolhamento das árvores .
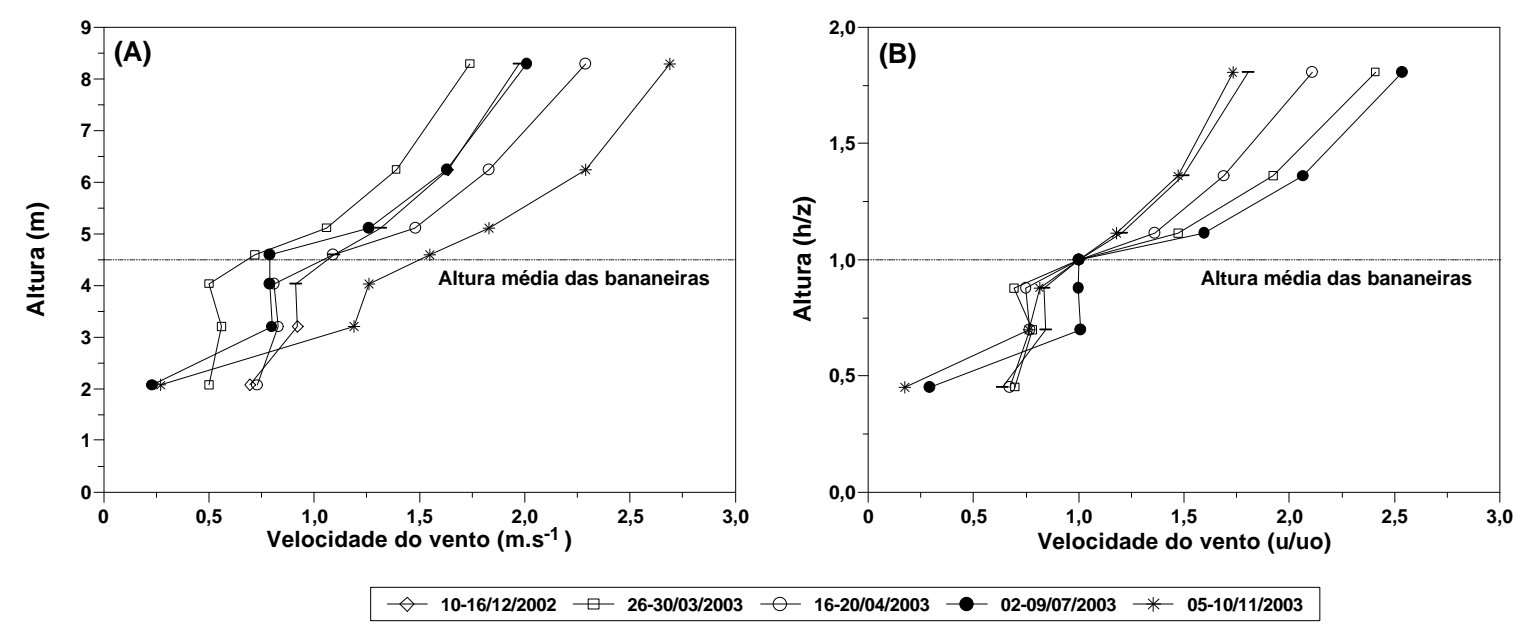

Figura 28 - Perfis médios $(A)$ e normalizados $\left(\mathrm{u} / \mathrm{u}_{0}\right)(B)$ da velocidade do vento no cultivo consorciado de café com banana 'Prata Anã', durante cinco períodos de medidas, em Mococa, SP

Na Figura 29, são apresentados os perfis médios da velocidade do vento no cultivo a pleno sol a cada duas horas no período entre 4 e 18 horas, para os dias 3/7/2003 e 6/11/2003.

O dia 6/7/2003 apresentou velocidade média de 1,47, enquanto que o dia 6/11/2003, 3,8 m.s. ${ }^{-1}$. A análise do dia 3/7/2003 (Figura 29A) evidencia que a velocidade do vento no segundo e terceiro níveis de medida permaneceram, para esse período de medida, próximas da igualdade ou até mesmo superior em relação ao nível de altura do 
dossel das bananeiras, como foi o caso do perfil entre 8-10 e 14-16 horas. Para o dia 6/11/2003 (Figura 29B), com velocidade do vento em valores superiores, é evidenciado o deslocamento do perfil logarítmico de vento para níveis acima do dossel das bananeiras, sendo que em se tratar de episódios com ocorrência de vento predominantemente no sentido transversal aos renques do cafeeiros, a velocidade do vento medida no sensor do nível 1 fosse praticamente nula.

(A)

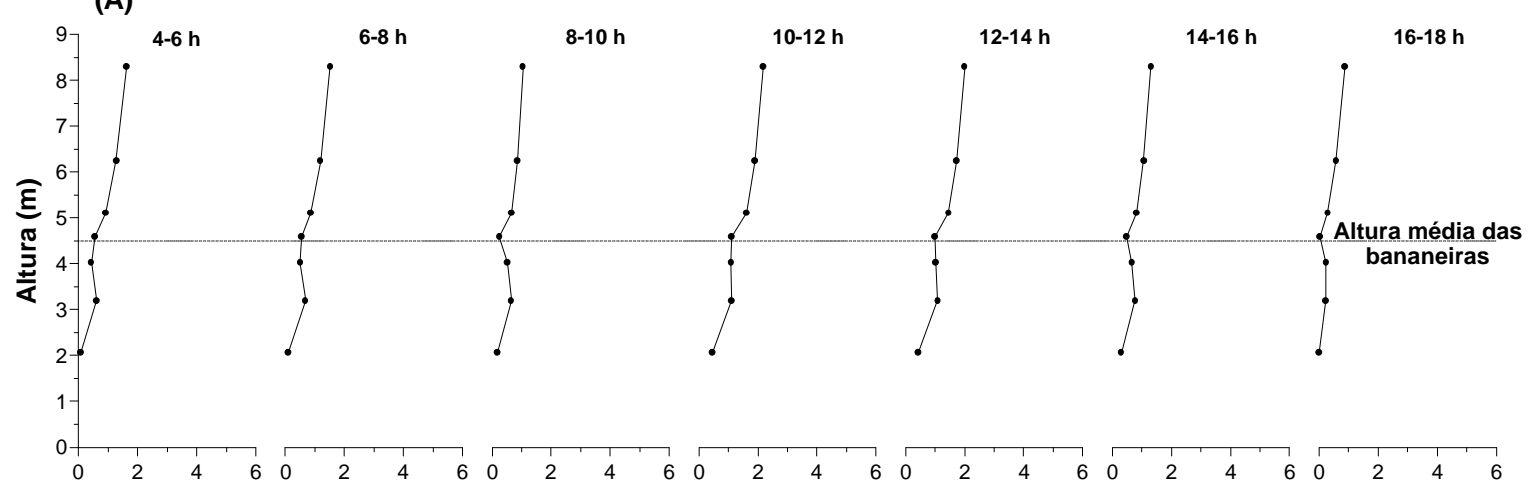

(B)

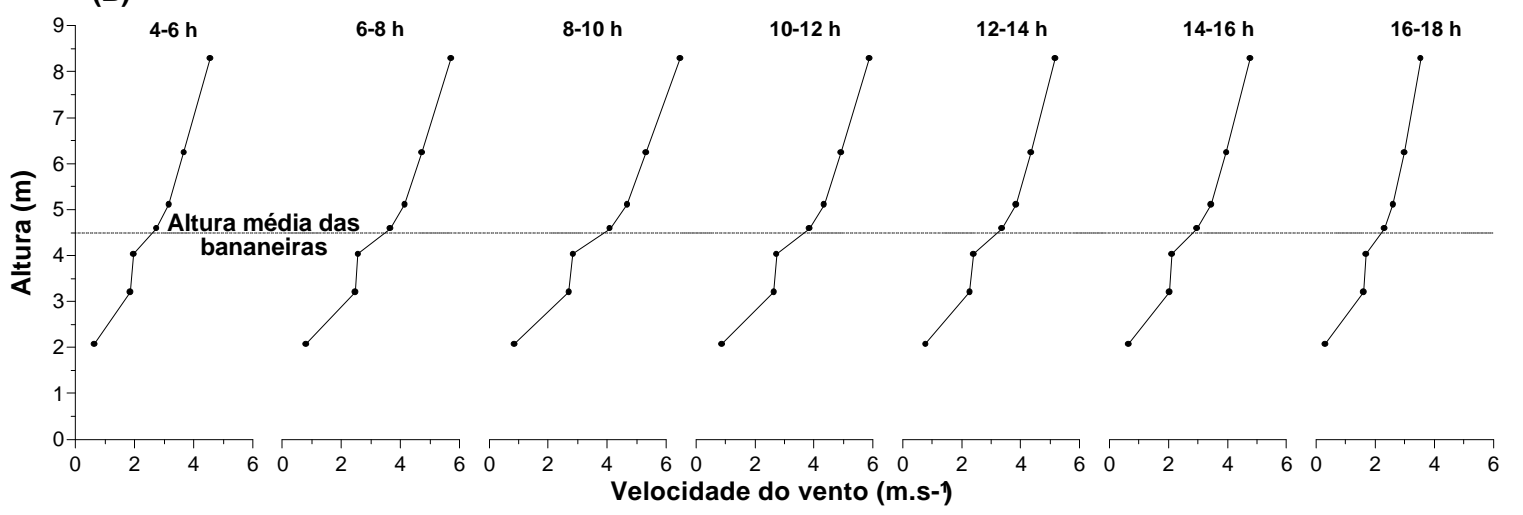

Figura 29 - Perfis médios da velocidade do vento $\left(\mathrm{m}^{\mathrm{s}} \mathrm{s}^{-1}\right)$, a cada duas horas, no cultivo consorciado de café com banana 'Prata Anã', nos dias 3 de julho (A) e 6 de novembro de 2003 (B), em Mococa, SP

\subsubsection{Perfis de temperatura e umidade}

Para a apresentação dos perfis de temperatura e umidade no cultivo a pleno sol, foram selecionados dois dias, em épocas distintas, em condição predominantemente ensolarada. Na Figura 30 são apresentados os perfis horários, a cada duas horas, da 
temperatura e pressão atual de vapor, no período das 6 às 18 horas para o dia 10 de fevereiro de 2003, representativo do período chuvoso da safra (Figura 10B).

Observando o comportamento dos perfis de temperatura do ar (Figura 30A), pode-se observar que no perfil das 6 horas a temperatura aumentou com a elevação da altura. Isso ocorreu devido ao resfriamento que a superfície (cultivo) provoca no ar próximo a ela (Rosemberg, 1974). A partir das 8 horas, com o aumento da incidência de radiação solar, e nos demais horários do dia, a temperatura decresce com a elevação da altura, a partir do topo da cultura, com temperaturas máximas ocorrendo no interior do cultivo, como observado por Saugier (1976) em cultivo de girassol e Begg et al. (1964), citado por Rosemberg (1974). No perfil das 18 horas começou a ocorrer a inversão desse comportamento.
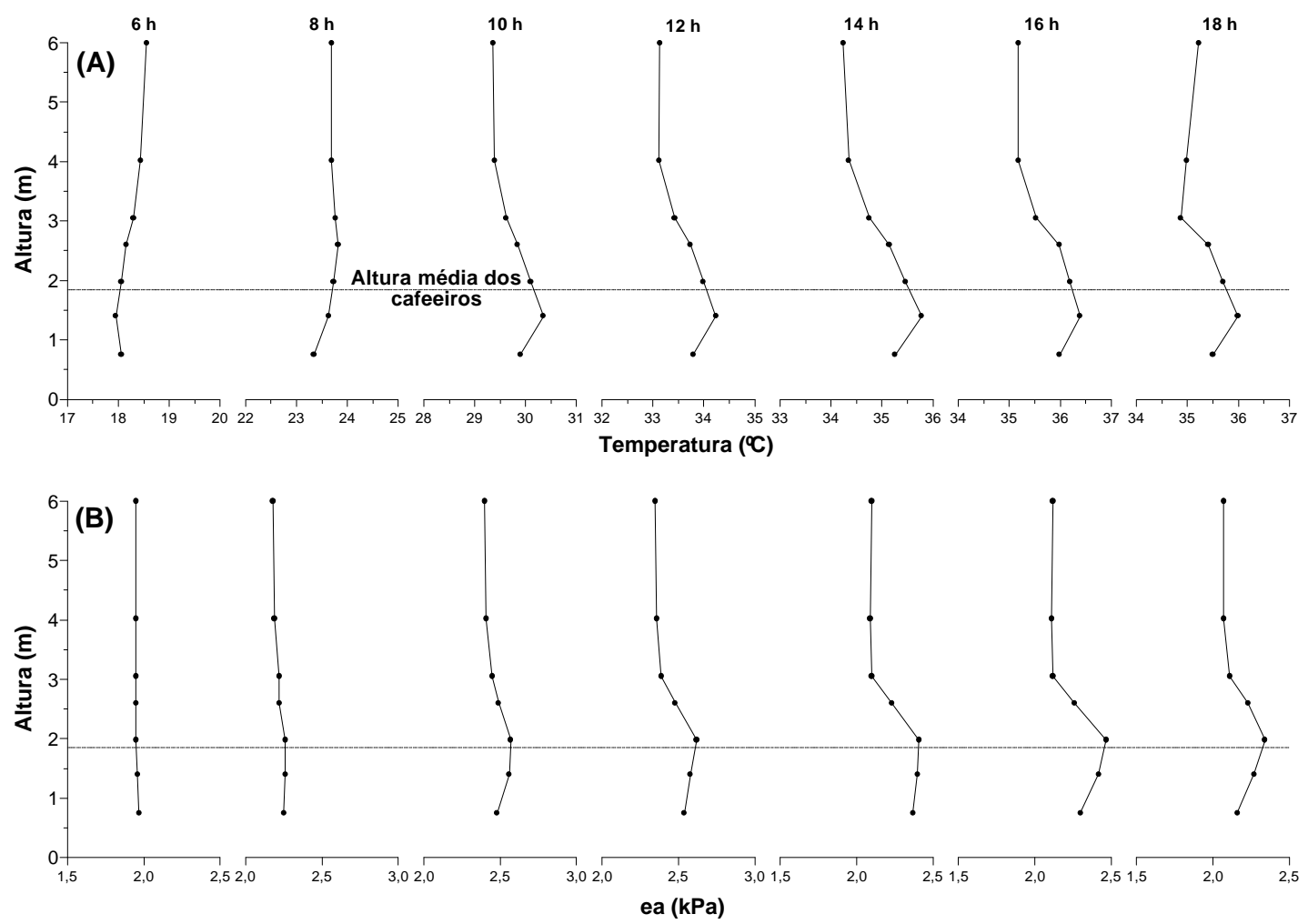

Figura 30 - Perfis médios horários da temperatura do ar $\left({ }^{\circ} \mathrm{C}\right)(\mathrm{A})$ e pressão atual de vapor $(\mathrm{kPa})(\mathrm{B})$, no cultivo de café a pleno sol, no dia 10 de fevereiro de 2003, em Mococa, SP 
Com relação a umidade do ar nesse episódio (Figura 30B), no perfil das 6 horas verificou-se uma pequena tendência de acréscimo do teor de umidade em relação a altura, comportamento típico de formação de orvalho sobre a superfície. A partir das 8 horas e mais significativamente a partir das 10 horas, o teor de umidade tende a decrescer com a elevação da altura a partir do topo da cultura. Segundo Rosemberg (1974) durante o período diurno, com o aumento da evaporação e da transpiração, o teor de vapor na altura da superfície vegetada aumenta.

Para o dia 3 de outubro de 2003 (Figura 31), a tendência do comportamento dos perfis de temperatura e umidade foi semelhante ao dia 10 de fevereiro, ou seja, durante $o$ dia os valores de temperatura e umidade tendem a decrescer com a elevação da altura, a partir do topo da cultura.
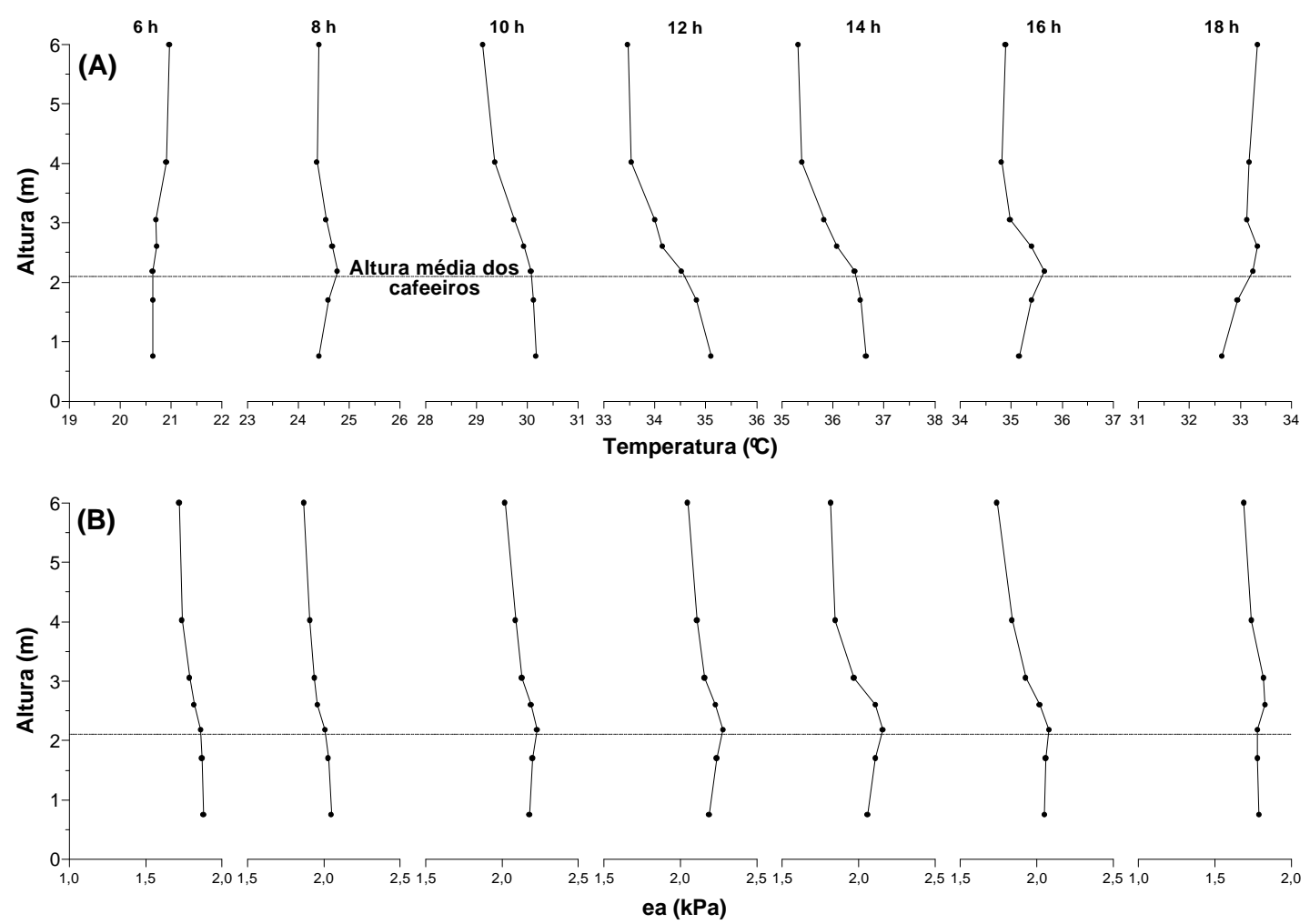

Figura 31 - Perfis médios horários da temperatura do ar $\left({ }^{\circ} \mathrm{C}\right)(\mathrm{A})$ e pressão atual de vapor (kPa) (B), no cultivo de café a pleno sol, no dia 3 de outubro de 2003, em Mococa, SP 
Nos perfis das 6 e das 18 horas, ocorre uma inversão desse comportamento, com o aumento da temperatura em relação a altura (Figura 31A). Com a umidade (Figura 31B), essa tendência não é fortemente observada.

Quando comparados os dois episódios analisados no cultivo a pleno sol (Figuras 30 e 31), é importante ressaltar o efeito da velocidade do vento (Figura 27), no comportamento da temperatura e umidade do ar. A maior incidência de vento no dia 3 de outubro, principalmente no período da manhã (Figura 27B), provocou uma homogeneização do ar na camada mais próxima a superfície, tornando os gradientes de umidade menos intensos. Com a temperatura do ar o efeito não foi tão significativo quanto a umidade, sendo que os gradiente permaneceram iguais ou superiores no episódio do dia 3 de outubro, principalmente no período da tarde, quando a incidência de vento diminui. É importante ressaltar que na época da amostragem de 3 de outubro, a região de Mococa estava sob efeito de elevada deficiência hídrica (Figura 10B), provocando aumento da temperatura próxima a superfície, atingindo valores superiores a $36^{\circ} \mathrm{C}$ e diminuição do teor de umidade, devido ao aumento do fluxo de calor sensível e a menor transpiração das plantas, respectivamente.

No cultivo consorciado, foram selecionados três episódios em épocas distintas e condição predominantemente ensolarada (Figuras 32 a 34), sendo apresentados para cada episódio, os perfis horários a cada duas horas da temperatura e pressão atual de vapor, no período das 6 às 18 horas.

Na Figura 32 são apresentados os perfis de temperatura e umidade do ar no dia 13 de dezembro de 2002, representativo do período chuvoso, onde pode se observar que a temperatura e a pressão atual de vapor diminuem em relação a altura, principalmente nas horas centrais do dia.

Observando o comportamento dos perfis de temperatura e umidade no dia 13 de dezembro de 2002, verifica-se que ambos os gradientes sofreram inflexões na altura da copa das bananeiras, alterando as condições microclimáticas. Isso ocorreu devido ao fornecimento de calor para o ar das folhas de bananeira. De maneira análoga, o aumento da transpiração durante o dia promoveu aumento do teor de umidade nos níveis próximo ao dossel das bananeiras.

No perfil das 6 horas, os valores de temperatura e umidade praticamente permaneceram constantes em relação a altura, tendo sido observado às 18 horas o início de inversão dos perfis em relação ao comportamento dos perfis diurnos. 

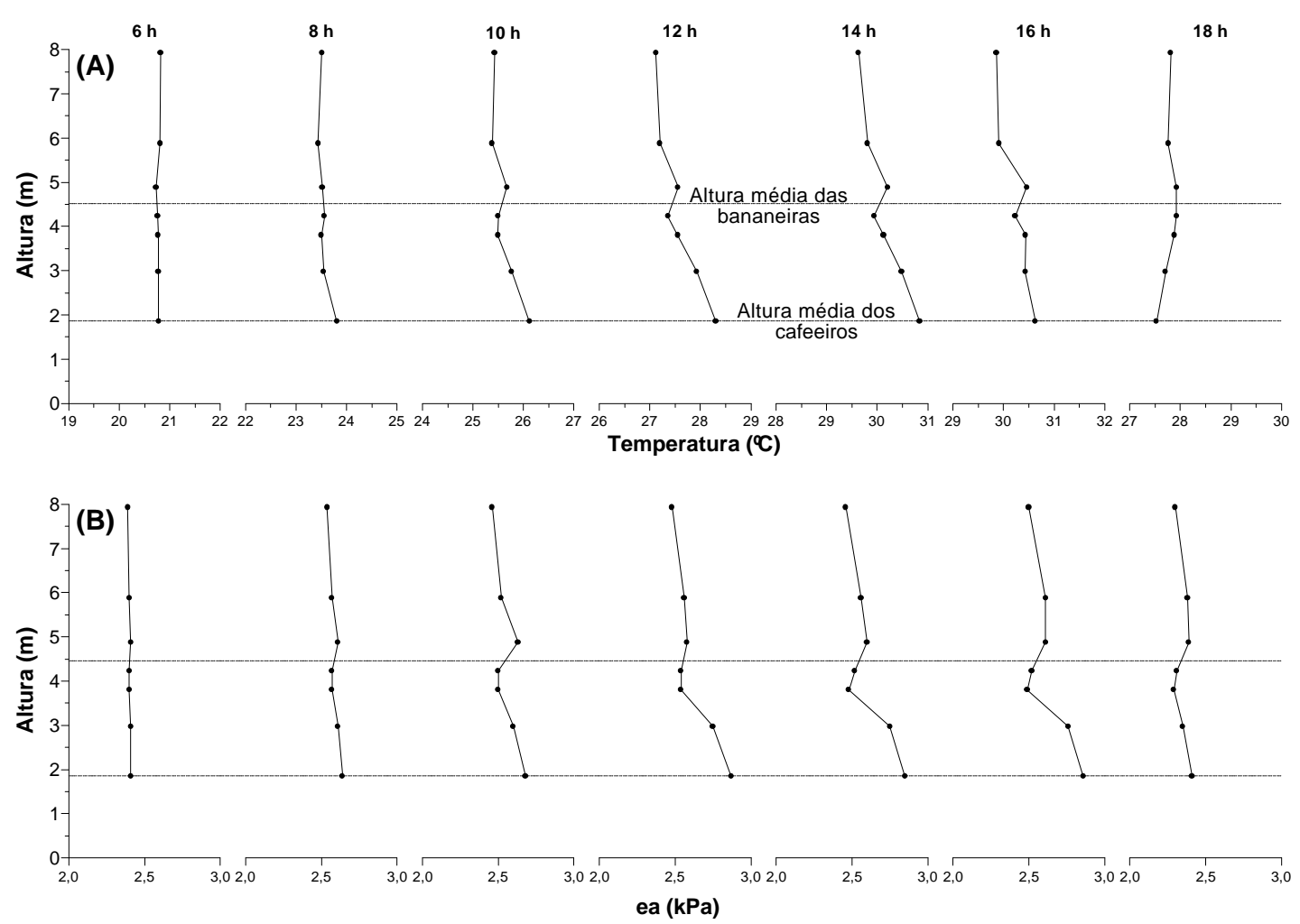

Figura 32 - Perfis médios horários da temperatura do ar $\left({ }^{\circ} \mathrm{C}\right)(\mathrm{A})$ e pressão atual de vapor $(\mathrm{kPa})(\mathrm{B})$, no cultivo de café consorciado com banana 'Prata Anã', no dia 13/12/2002, em Mococa, SP

É importante ressaltar que a presença das bananeiras, promovendo um efeito de quebra-vento, fez com que os gradientes de temperatura acima do dossel dos cafeeiros até a altura da copa das bananeiras (níveis 1 e 3 de medida) fossem reduzidos, comportamento diferente do cultivo a pleno sol em época úmida (Figura 30). No dia 13/12/2002, em condição ensolarada e de pouco vento, os gradientes nos dois primeiros metros acima do dossel dos cafeeiros, para os horários das 12, 14 e 16 horas foram -0,36, $-0,36$ e $-0,09^{\circ} \mathrm{C} . \mathrm{m}^{-1}$, respectivamente. Para o cultivo a pleno sol, no dia 10/2/2003 (Figura $30 \mathrm{~A})$, em condição ensolarada e de pouco vento, também esses mesmos gradientes foram de $-0,42,-0,54$ e $-0,49^{\circ} \mathrm{C} \cdot \mathrm{m}^{-1}$, respectivamente.

Esse comportamento já tinha sido identificado na realização da caracterização microclimática (ítem 4.2.3), quando foi verificada a maior ocorrência de temperatura máximas no ponto central da parcela consorciada em relação ao cultivo a pleno sol. 
No caso da pressão atual de vapor, a tendência de menores gradientes no cultivo consorciado, para o dia 13/12/2002, em relação ao dia 10/2/2003 no cultivo a pleno sol, foi mais significativa no primeiro metro acima do dossel dos cafeeiros, pois segundo Rosemberg (1974), as mudanças da umidade do ar com a elevação da altura são mais significativas na altura da superfície vegetada. Nesse caso, os gradientes de pressão atual de vapor para os horários das 12, 14 e 16 horas foram de -0,11, -0,09 e $\quad-0,09$ kPa.m ${ }^{-1}$ para o cultivo consorciado e $-0,21,-0,29$ e $-0,33 \mathrm{kPa} \cdot \mathrm{m}^{-1}$ para o cultivo a pleno sol.

Embora essa comparação tenha ressalvas, pois os gradientes de temperatura $\mathrm{e}$ pressão atual de vapor não foram realizados no mesmo dia, as mesmas condições de ambiente como dia ensolarado, pouca incidência de vento e em se tratar de época chuvosa, permitem observar as diferenças promovidas pela introdução das bananeiras no cultivo de café.

No episódio de 3 de julho de 2003 (Figura 33), assim como no episódio anterior, ocorreram inflexões nos perfis de temperatura e pressão atual de vapor na altura da copa das bananeiras nos perfis diurnos. Com relação a temperatura do ar, manteve-se a tendência de diminuição dos gradientes nos níveis acima do cafeeiro, embora seja ressaltar que o sensor do psicrômetro do nível 1 estava situado no interior do dossel dos cafeeiros.

Apesar de nessa época as bananeiras promoverem menor ação sobre o vento (Figura 28), o que poderia aumentar esses gradientes logo acima dos cafeeiros, de maneira semelhante ao cultivo a pleno sol, isso não ocorreu, provavelmente devido à seca que já aumentava as deficiências hídricas em julho, fazendo com que maior parte da energia disponível fosse destinada ao aquecimento do ar, influenciado ainda pela baixa ocorrência de vento no cultivo nesse dia (Figura 29A).

A ocorrência do período seco também pode explicar, apesar da baixa incidência de vento e a pouca ação das bananeiras como quebra-vento nessa época do ano, o fato dos perfis de pressão atual de vapor apresentarem pequenos gradientes entre os níveis de medida, confirmado com os menores valores absolutos apresentados.

Outro fato interessante nesse episódio é a ocorrência da inversão no perfil de temperatura das 18 horas, quando o resfriamento do ar provocado pela superfície já se tornava evidente, em se tratar de período de inverno 

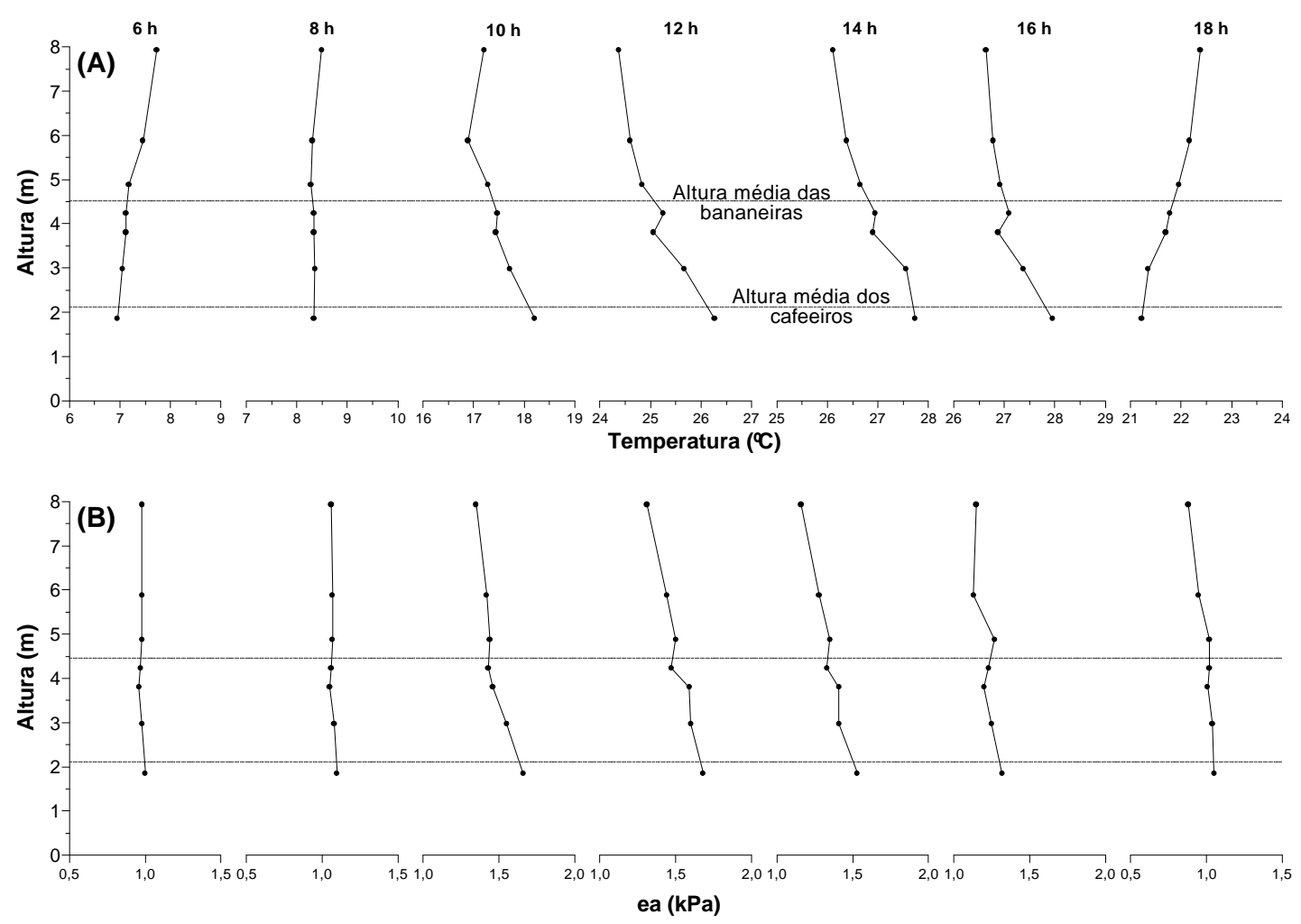

Figura 33 - Perfis médios horários da temperatura do ar $\left({ }^{\circ} \mathrm{C}\right)(\mathrm{A})$ e pressão atual de vapor $(\mathrm{kPa})(\mathrm{B})$, no cultivo de café consorciado com banana 'Prata Anã', no dia 3/7/2003, em Mococa, SP

O episódio de 6 de novembro de 2003 (Figura 34), apresentava transição do período seco para o chuvoso na região (Figura 10B). Nesse dia, maiores velocidades de vento (Figura 29B), provocaram uma homogeneização do ar sobre os cafeeiros, fazendo com que praticamente não ocorressem gradientes até a altura das bananeiras. Os elevados valores de temperatura do ar no sensor do nível 1 também podem ser explicados, assim como no episódio anterior, devido a sua posição no interior do dossel. De maneira análoga, o comportamento dos perfis de umidade, nesse episódio, também apresentou pequenos gradientes.

A partir das 16 horas, ocorreu um aumento da nebulosidade, provocando uma alteração no comportamento dos perfis de temperatura, apresentando praticamente uma isotermia entre os níveis de medida, sendo que as 18 horas, a presença de chuva sobre o experimento provocou aumento significativo do teor de umidade (Figura 34B). 

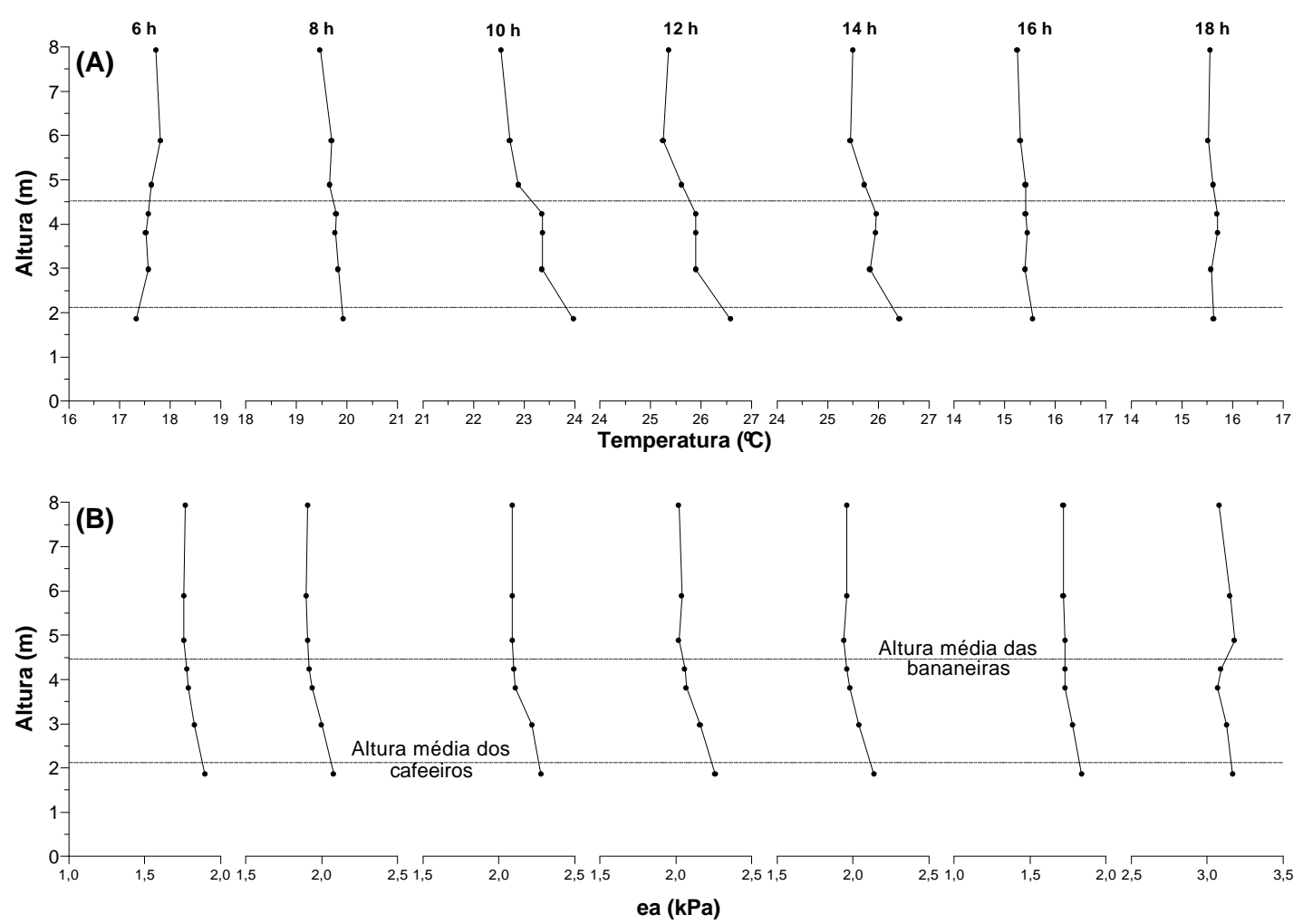

Figura 34 - Perfis médios horários da temperatura do ar $\left({ }^{\circ} \mathrm{C}\right)(\mathrm{A})$ e pressão atual de vapor $(\mathrm{kPa})(\mathrm{B})$, no cultivo de café consorciado com banana 'Prata Anã', no dia 6/11/2003, em Mococa, SP

\subsubsection{Caracterização aerodinâmica}

Para o estudo da caracterização aerodinâmica, foram selecionados os perfis próximos a neutralidade. Foram excluídos os perfis com distorções que resultaram em valores de deslocamento do plano zero $(d)$, acima do primeiro nível de medida (nível 3 para o cultivo a pleno sol e nível 4 para o cultivo consorciado).

$\mathrm{Na}$ Tabela 13 são apresentados os valores médios das estimativas dos parâmetros $d, z_{o}$ e $u^{*}$, bem como suas relações com a altura da cultura $(\mathrm{H})$ no cultivo a pleno sol, para dois períodos de medida. O período 1 engloba as medições realizadas nas amostragens de 11 a 16 de janeiro e 7 a 10 de fevereiro de 2003, totalizando 28 perfis com vento no sentido perpendicular aos renques e 8 perfis com vento no sentido paralelo aos renques. O período 2 engloba as medidas realizadas nas amostragens de 26 a 31 de julho e 30 de setembro a 6 de outubro de 2003, totalizando 32 perfis com vento no sentido perpendicular aos renques e 7 perfis com vento no sentido paralelo aos renques. 
Tabela 13. Estimativas dos parâmetros velocidade característica $\left(u^{*}\right)$, deslocamento do plano zero $(d)$, comprimento da rugosidade $\left(z_{0}\right)$, e suas relações com o topo da cultura $(H)$, para diferentes períodos de medição e de direção de vento predominante, em cultivo de café a pleno sol, em Mococa, SP

\begin{tabular}{|c|c|c|c|c|c|c|c|c|}
\hline \multirow{2}{*}{ Período * } & \multirow{2}{*}{$\begin{array}{l}\text { Direção do } \\
\text { vento** }\end{array}$} & \multirow{2}{*}{$u^{*}\left(\mathrm{~m} \cdot \mathrm{s}^{-1}\right)$} & \multirow[t]{2}{*}{$d$} & \multirow[t]{2}{*}{$z_{0}$} & \multicolumn{2}{|c|}{ Desvio padrão } & \multirow[b]{2}{*}{$d / H$} & \multirow[b]{2}{*}{$z_{d} / \mathrm{H}$} \\
\hline & & & & & \multicolumn{2}{|c|}{$d \quad z_{0}$} & & \\
\hline \multirow{3}{*}{1} & Perpendicular & 0,27 & 1,631 & 0,258 & $\frac{m}{0,239}$ & 0,174 & 0,84 & 0,13 \\
\hline & Paralelo & 0,26 & 1,553 & 0,336 & 0,241 & 0,158 & 0,80 & 0,17 \\
\hline & Todos & 0,27 & 1,614 & 0,275 & 0,238 & 0,172 & 0,83 & 0,14 \\
\hline \multirow{3}{*}{2} & Perpendicular & 0,40 & 1,503 & 0,317 & 0,206 & 0,168 & 0,77 & 0,16 \\
\hline & Paralelo & 0,31 & 1,616 & 0,245 & 0,289 & 0,178 & 0,83 & 0,13 \\
\hline & Todos & 0,38 & 1,524 & 0,303 & 0,223 & 0,170 & 0,78 & 0,16 \\
\hline
\end{tabular}

${ }^{*}$ Período 1; amostragens de 11 a 16 de janeiro e 7 a 10 de fevereiro de 2003 e Período 2: amostragens de 26 a 31 de julho e 30 de setembro a 6 de outubro de 2003.

** Direção do vento em relação ao renque de cafeeiros. Todos indica a análise conjunta de todos os perfis utilizados.

Os valores médios de $d$ foram de 1,614 m $( \pm 0,238)$ e $1,524 \mathrm{~m}( \pm 0,223)$, determinando relação $d / H$ de 0,83 e 0,78 para os períodos 1 e 2 , respectivamente. $O$ valor de $z_{0}$ médio foi de $0,275( \pm 0,238)$ e $0,303( \pm 0,238)$, representando relação de $z_{d}$ h de 0,14 e 0,16 , para os períodos 1 e 2 , respectivamente. Quando analisados os perfis em relação a direção de vento predominante, houve uma inversão em relação aos valores de $d$ e $z_{0}$, em relação aos períodos amostrados. É importante ressaltar que $d$ e $z_{0}$ foram influenciados pela velocidade característica nos períodos de medidas, com queda significativa de seu valor quando a direção predominante foi no sentido dos renques, no período 2 , em relação ao sentido perpendicular para o mesmo período.

$\mathrm{Na}$ Figura 35 são apresentadas as relações de $d$ e $z_{0}$ com $u^{*}$ no cultivo a pleno sol para os perfis agrupados no período 1, com vento predominante no sentido transversal aos renques (Figura 35A e 35B) e paralelos ao renque (Figura 35C e 35D), bem como nas amostragens do período 2, com direção do vento predominante no sentido transversal aos renques (Figura 35E e 35F) e paralelos ao renque (Figura 35G e 35H).

Como pode ser observado na Figura 35 (A, C, E e G), os resultados evidenciam a influência da velocidade característica $\left(u^{*}\right)$ no comportamento de $d$ e $z_{0}$. Quando $u^{*}$ aumenta, o valor de $d$ diminui e o valor de $z_{0}$ aumenta. Resultados semelhantes desse comportamento foram encontrados por Uchima (1976) em arroz, Sentelhas et. (1993) em 
videira e Righi et al. (2003) em cafeeiro recém-implantado, entre outros. Monteith (1963), assim como Rosemberg (1974), relatam que quanto maior a velocidade do vento, maior o encurvamento das plantas devido ao transporte de momentum para a vegetação, reduzindo a altura em que ocorre a absorção de momentum (d), e por conseqüência aumentando o comprimento da rugosidade $\left(z_{0}\right)$.

A diminuição de $d$ em relação ao aumento de $u^{*}$, ocorre com maior intensidade quando o vento foi paralelo ao sentido dos renques (Figura $35 \mathrm{C}$ e $35 \mathrm{G}$ ), devido aos maiores coeficientes angulares, em módulo, em relação aos perfis com vento perpendicular aos renques (Figura 35A e 35E), pois nesses últimos, a maior resistência do cafeeiro ao encurvamento faz com que $d$ permaneça em seus valores máximos. De maneira semelhante, quando o vento era paralelo ao sentido dos renques o aumento de $z_{0}$ era mais intenso com o aumento de $u^{*}$.

Analisando as características aerodinâmicas em cultivos de cafeeiros recémimplantados em renques, Righi et al. (2003) obtiveram resultados com comportamento semelhantes, o mesmo não sendo encontrado por Sentelhas et al. (1993) em cultivo de videira em espaldeira (renque), embora esses últimos autores tenham observado essa tendência em um pequeno conjunto de dados em condições de atmosfera nem sempre próxima a neutralidade.

Comparando os dois períodos de amostragem, a influência de $u^{*}$ no comportamento de $d$ e $z_{0}$, foi mais intensa, com maiores coeficientes angulares, quando analisados os dados do primeiro período de amostragem (Figura 35A a 35D) em relação ao segundo período de amostragem (Figura 35E a 35H), em qualquer condição de vento predominante. Observando as características da vegetação (Tabela 2), o segundo período de amostragem apresentava maior altura dos cafeeiros. A influência do porte da vegetação nos parâmetros aerodinâmicos também foi observado em café por Jaramillo-Robledo (1975) e Righi et al. (2003). 

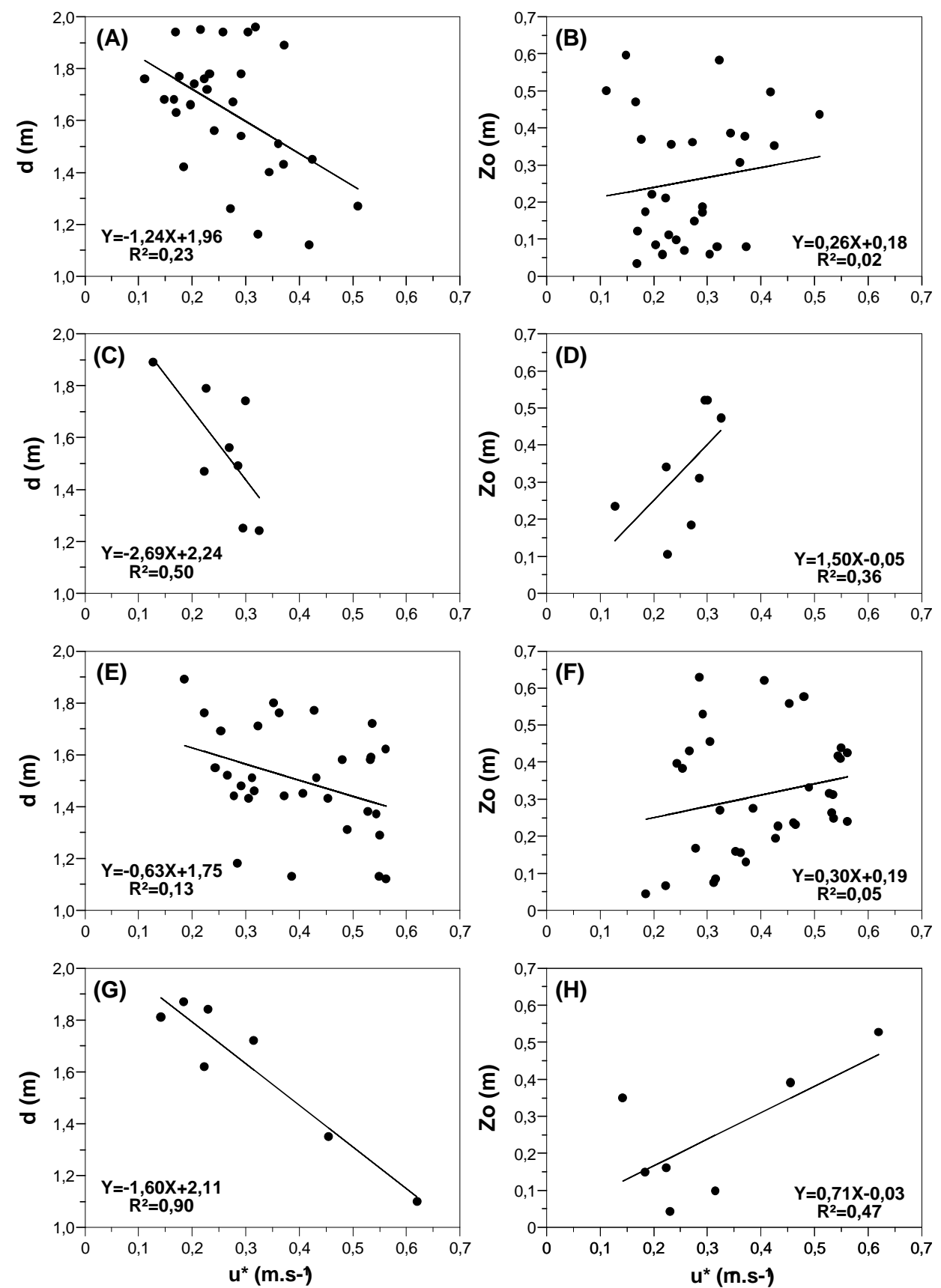

Figura 35 - Relação do deslocamento do plano zero (d) e do comprimento da rugosidade da superfície $\left(z_{0}\right)$ com a velocidade característica do vento $\left(u^{*}\right)$ nos períodos de 11-16/1/2003 e 7-10/2/2003 com direção do vento no sentido transversal dos renques $(A$ e $B)$ e direção no sentido dos renques $(C$ e $D)$ e nos períodos de 26-31/7/2003 e 30/9-6/10/2003 com direção do vento no sentido transversal dos renques (E e F) e direção no sentido dos renques ( $\mathrm{G}$ e $H$ ) em cultivo de café a pleno sol em Mococa,SP 
Os valores médios de $d$ para o cultivo consorciado, foram de $3,66 \mathrm{~m}( \pm 0,428)$, $4,305 \mathrm{~m}( \pm 0,197)$ e $3,897 \mathrm{~m}( \pm 0,263)$, determinando relação $d / \mathrm{H}$ de $0,81,0,96$ e 0,87 para os períodos 1, 2 e 3, respectivamente. Assim como no cultivo a pleno sol, os valores de $d$, quando analisados os perfis em relação a direção de vento predominante, sofreram uma inversão em relação aos períodos. É importante ressaltar que o período 2 de medidas apresentou episódios com baixa intensidade de vento (Figura 29A), originando velocidade característica baixa e valores de $d$ mais elevados que os outros períodos. A influência da velocidade do vento nos parâmetros aerodinâmicos, também foi constatada por outros autores (Jaramillo-Robledo, 1975; Kustas, 1989; Shaw \& Pereira, 1982).

O valor de $z_{0}$ médio foi de $0,189 \mathrm{~m}( \pm 0,151), 0,060 \mathrm{~m}( \pm 0,048)$ e $0,042 \mathrm{~m}( \pm 0,037)$, representando relação de $z_{d} / \mathrm{h}$ de $0,04,0,013$ e 0,001, para os períodos 1 , 2 e 3, respectivamente. A rekalçaõa $d / \mathrm{H}$ foi menor do que no cultivo a pleno sol, o que pode ter sido influenciado pela disposição das bananeiras, diminuindo o "selamento" da cultura a penetração do vento (Pereira, 1990). Para o período 1, os maiores valores de $z_{0}$ podem ter tido influência da arquitetura do dossel das bananeiras, com maior enfolhamento do que os outros dois períodos.

$\mathrm{Na}$ Figura 36 são apresentadas as relações de $d$ e $z_{0} \operatorname{com} u^{*}$ no cultivo consorciado, para os perfis agrupados nas amostragens do período 1 , com vento predominante no sentido transversal aos renques (Figura 36A e 36B) e paralelos ao renque (Figura 36C e 36D), bem como no período 2 de medidas, com direção do vento predominante no sentido transversal aos renques (Figura 36E e 36F) e paralelos ao renque (Figura $36 \mathrm{G}$ e $36 \mathrm{H}$ ) e no período 3 de medidas, com vento predominante no sentido transversal aos renques (Figura $36 \mathrm{I} \mathrm{e} 36 \mathrm{~J}$ ).

Assim como ocorreu no cultivo a pleno sol, os resultados evidenciam a influência da velocidade característica $\left(u^{*}\right)$ no comportamento dos valores de $d$ e $z_{0}$ em todos os período analisados, em qualquer sentido predominante do vento. Como observado por outros autores (Hicks (1973), citado por Sentelhas et al. (1993) e Righi et al. (2003)) e também constatado no cultivo a pleno sol, no cultivo consorciado a direção predominante do vento também influenciou, embora em menor grandeza, a relação de $d$ e $z_{0}$ com $u^{*}$. Quando o vento foi predominante no sentido perpendicular ao renque (Figura $36 \mathrm{~A}, 35 \mathrm{C}$ e 35I) o coeficiente angular foi menor, em módulo, do que quando o vento foi predominante no sentido pararelo aos renques (Figura 36E e 36G). 

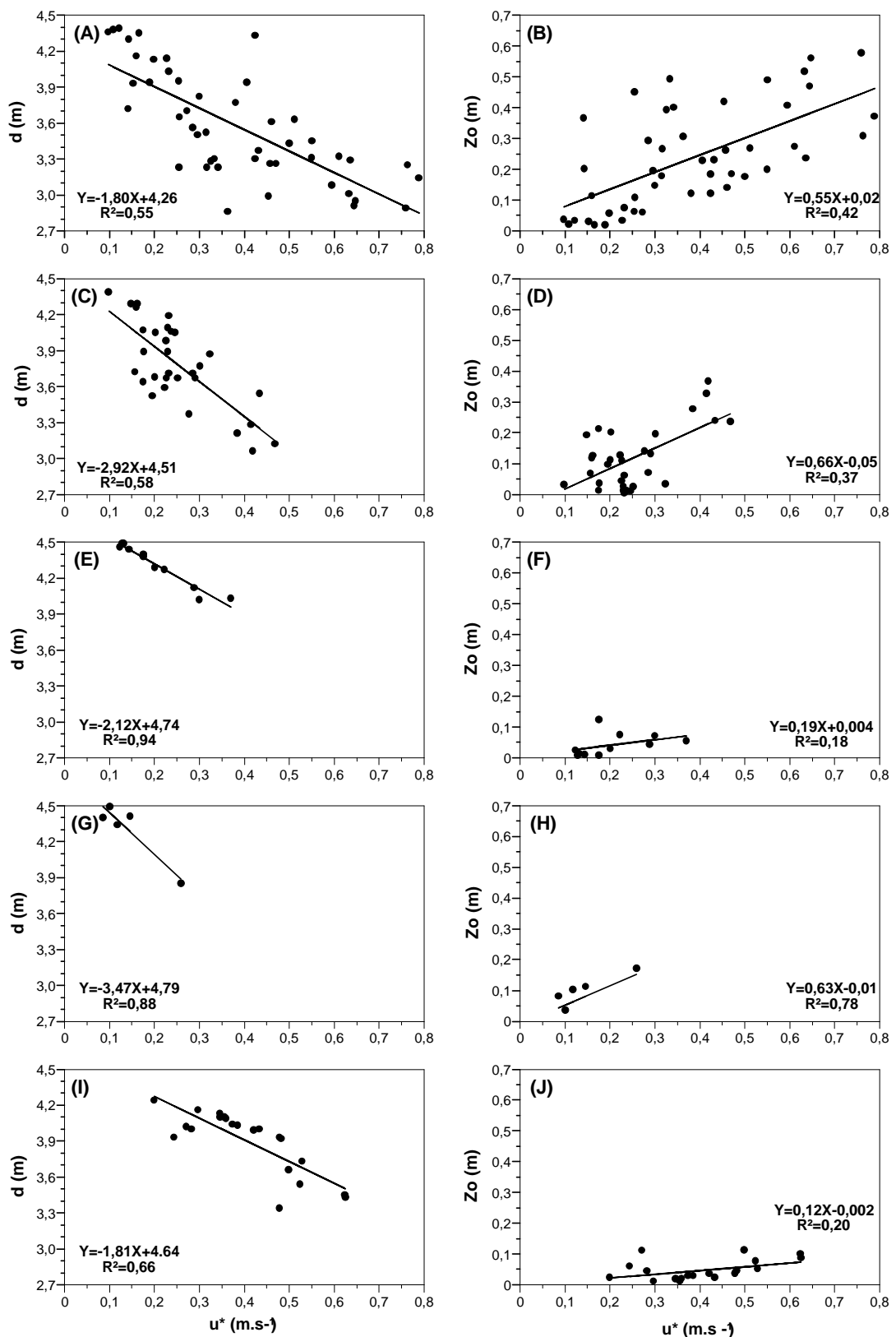

Figura 36 - Relação do deslocamento do plano zero (d) e do comprimento da rugosidade da superfície $\left(z_{0}\right)$ com a velocidade característica do vento $\left(u^{*}\right)$ nos períodos de 11-17/12/2002, 26-30/3/2003 e 16-20/4/2003 com direção do vento no sentido transversal dos renques ( $A$ e $B$ ) e direção no sentido dos renques ( $C$ e $D)$; no período de 2-9/7/2003 com direção do vento no sentido transversal dos renques (E e $F)$ e direção no sentido dos renques $(G$ e $H)$ e no período de 410/11/2003 com direção no sentido transversal dos renques (I e J) em cultivo de café consorciado com banana 'Prata Anã' em Mococa,SP 
Comparando os dois primeiros períodos de amostragem, a influência de $u^{*}$ no comportamento de $d$ e $z_{0}$, foi mais intensa, com maiores coeficientes angulares, quando analisados os dados do segundo de amostragem (Figura $36 \mathrm{E}$ a $35 \mathrm{H}$ ) em relação ao primeiro período de amostragem (Figura 35E a 35H), em qualquer condição de vento predominante.

Conforme apresentado na Figura 28, em julho de 2003 as relações de vento no interior do dossel das bananeiras com o topo da cultura foram maiores do que nos outros período de amostragem, devido a menor ação das bananeiras na redução do vento, ocasionada pelo desbaste. Isso fez com que, mesmo em época de baixa incidência de vento (Figura 29A), apresentando as maiores médias de $d$ (Tabela 14), os coeficientes angulares da relação de $u^{*}$ com $d$ nesse período fossem maiores do que o período 1 , em qualquer direção de vento predominante.

\subsubsection{Balanço de energia}

A partição da energia disponível ao sistema (SR) nos fluxos de calor latente $(\lambda E)$, de calor sensível (H) e de calor no solo (FS) varia de acordo com o desenvolvimento da cultura, condições atmosféricas e disponibilidade hídrica do solo (Pedro Júnior, 1977; Pereira et al., 1997; Marin, 2003).

Na Tabela 15 é apresentada a variação diária dos componentes do balanço de energia no período diurno, compreendido entre as 6 às 19 horas, no cultivo a pleno sol para duas épocas do ano. Na primeira época, as medições foram realizadas no período chuvoso durante o verão, nos meses de janeiro e fevereiro de 2003. A segunda época englobou as medições de julho a outubro de 2003, meses de inverno e início de primavera, quando a região apresentava deficiências hídricas (Figura 10).

Analisando a relação $\lambda E / S R$ durante as duas épocas analisadas, pode se verificar que no verão seu valor médio foi de 0,78 , com valores entre 0,72 a 0,86 . Já para o período seco, essa relação foi de 0,72 , com variações entre 0,64 e 0,81. Por outro lado, a relação $\mathrm{H} / \mathrm{SR}$ foi de 0,20 no verão e de 0,24 no inverno, com valores atingindo, nessa época 0,33 , provavelmente devido a menor disponibilidade de água para evapotranspiração.

Gutierrez \& Menzer (1994), em estudos de balanço de energia em cafeeiros no Hawaii, verificaram que independentemente do estágio de desenvolvimento da cultura, o 
fluxo de calor latente representou maior parcela do saldo de radiação, o mesmo verificado por Jaramillo-Robledo \& Gomez-Gomez (1989) na Colômbia.

Tabela 15. Variação diária dos valores de saldo de radiação (SR), fluxo de calor latente $(\lambda E)$, fluxo de calor sensível $(H)$ e fluxo de calor para o solo (FS)(MJ.m $\left.{ }^{-2} \cdot d_{i a}^{-1}\right)$, em período diurno, e relações de $\lambda E, H$ e FS com $S R$, durante duas épocas do ano, em cultivo de café a pleno sol, em Mococa, SP

\begin{tabular}{|c|c|c|c|c|c|c|c|c|}
\hline \multirow{2}{*}{ Época } & \multirow{2}{*}{ Dia } & SR & $\lambda E$ & $\mathrm{H}$ & FS & \multirow{2}{*}{$\lambda E / S R$} & \multirow{2}{*}{$\mathrm{H} / \mathrm{SR}$} & \multirow{2}{*}{$\mathrm{FS} / \mathrm{SR}$} \\
\hline & & \multicolumn{4}{|c|}{ MJ.m $m^{-2} \cdot \mathrm{dia}^{-1}$} & & & \\
\hline \multirow[t]{11}{*}{ Chuvosa } & $11 / 1 / 2003$ & 12,49 & $-10,77$ & $-1,71$ & $-0,01$ & 0,86 & 0,14 & 0,00 \\
\hline & $12 / 1 / 2003$ & 12,95 & $-10,35$ & $-2,41$ & $-0,20$ & 0,80 & 0,19 & 0,01 \\
\hline & $13 / 1 / 2003$ & 11,07 & $-9,02$ & $-1,97$ & $-0,09$ & 0,81 & 0,18 & 0,01 \\
\hline & $14 / 1 / 2003$ & 15,29 & $-11,80$ & $-3,29$ & $-0,20$ & 0,77 & 0,22 & 0,01 \\
\hline & $15 / 1 / 2003$ & 16,89 & $-12,08$ & $-4,61$ & $-0,20$ & 0,72 & 0,27 & 0,01 \\
\hline & $16 / 1 / 2003$ & 15,41 & $-11,39$ & $-3,73$ & $-0,28$ & 0,74 & 0,24 & 0,02 \\
\hline & 7/2/2003 & 17,61 & $-13,47$ & $-3,82$ & $-0,33$ & 0,77 & 0,22 & 0,01 \\
\hline & $8 / 2 / 2003$ & 18,37 & $-14,49$ & $-3,49$ & $-0,39$ & 0,79 & 0,19 & 0,02 \\
\hline & 9/2/2003 & 18,55 & $-14,64$ & $-3,40$ & $-0,51$ & 0,79 & 0,18 & 0,03 \\
\hline & $10 / 2 / 2003$ & 19,30 & $-15,29$ & $-3,39$ & $-0,61$ & 0,79 & 0,18 & 0,03 \\
\hline & Média & 15,79 & $-12,33$ & $-3,18$ & $-0,28$ & 0,78 & 0,20 & 0,02 \\
\hline \multirow[t]{14}{*}{ Seca } & 26/7/2003 & 8,14 & $-5,76$ & $-2,20$ & $-0,18$ & 0,71 & 0,27 & 0,02 \\
\hline & 27/7/2003 & 9,83 & $-6,96$ & $-2,67$ & $-0,20$ & 0,71 & 0,27 & 0,02 \\
\hline & 28/7/2003 & 9,53 & $-6,56$ & $-2,76$ & $-0,21$ & 0,69 & 0,29 & 0,02 \\
\hline & 29/7/2003 & 10,83 & $-6,91$ & $-3,67$ & $-0,24$ & 0,64 & 0,33 & 0,02 \\
\hline & $30 / 7 / 2003$ & 9,86 & $-6,45$ & $-3,14$ & $-0,26$ & 0,66 & 0,32 & 0,02 \\
\hline & $31 / 7 / 2003$ & 7,23 & $-5,40$ & $-1,57$ & $-0,26$ & 0,75 & 0,22 & 0,03 \\
\hline & $30 / 9 / 2003$ & 14,62 & $-10,55$ & $-3,57$ & $-0,50$ & 0,72 & 0,25 & 0,03 \\
\hline & $1 / 10 / 2003$ & 15,89 & $-11,57$ & $-3,67$ & $-0,65$ & 0,73 & 0,23 & 0,04 \\
\hline & 2/10/2003 & 14,72 & $-11,66$ & $-2,38$ & $-0,68$ & 0,79 & 0,16 & 0,05 \\
\hline & 2/10/2003 & 15,02 & $-10,87$ & $-3,37$ & $-0,79$ & 0,72 & 0,22 & 0,06 \\
\hline & $3 / 10 / 2003$ & 14,58 & $-10,98$ & $-2,81$ & $-0,79$ & 0,75 & 0,19 & 0,06 \\
\hline & 4/10/2003 & 15,06 & $-10,22$ & $-3,95$ & $-0,89$ & 0,68 & 0,26 & 0,06 \\
\hline & $5 / 10 / 2003$ & 12,12 & $-9,80$ & $-1,68$ & $-0,64$ & 0,81 & 0,14 & 0,05 \\
\hline & Média & 12,11 & $-8,74$ & $-2,88$ & $-0,48$ & 0,72 & 0,24 & 0,04 \\
\hline
\end{tabular}


Com relação ao fluxo de calor para o solo, quando se leva em consideração apenas os valores do período diurno, seus valores médios representaram cerca de $2 \%$ do SR no verão e $4 \%$ no período de inverno-primavera, valores semelhantes aos obtidos por Jaramillo-Robledo \& Gomez-Gomez (1989). As diferenças entre as duas épocas do ano podem ser atribuídas à maior cobertura de solo na entrelinha no período de verão, assim como constatado por Marin et al.(2002) em pomar de citros.

Na Figura 37 é apresentada a variação horária dos componentes do balanço de energia no cultivo a pleno sol nos dias 10/2/2003 (Figura 37A) e 29/7/2003 (Figura 37B), predominantemente ensolarados.

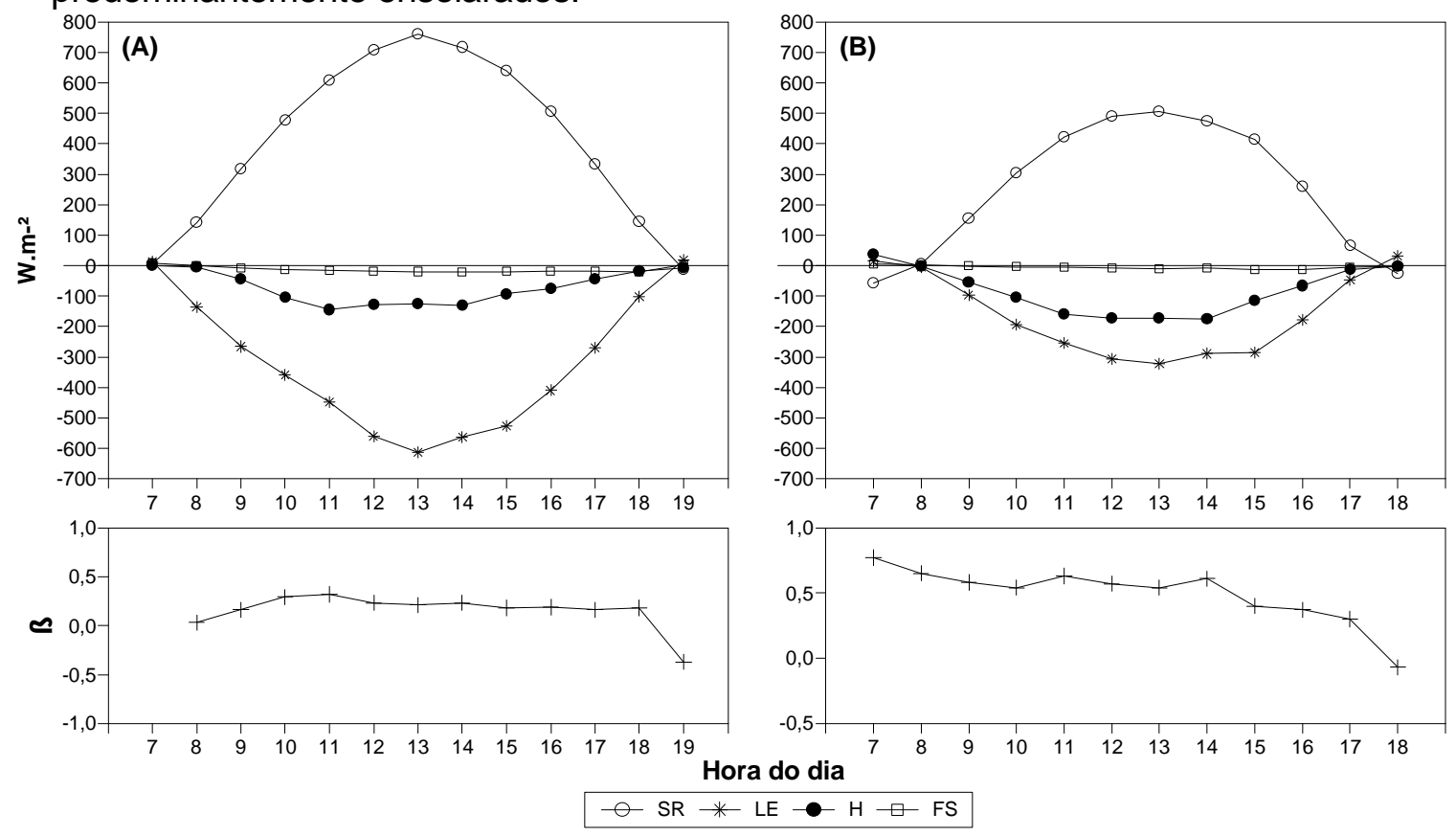

Figura 37 - Variação horária do saldo de radiação (SR), do fluxo de calor latente (LE), do fluxo de calor sensível $(H)$, do fluxo de calor no solo (FS) e da razão de Bowen (B) nos dias 10/2/2003 (A) e 29/7/2003 (B), em cultivo de café a pleno sol, em Mococa, SP

No dia 10/2/2003, durante a estação chuvosa, o total do saldo de radiação no período diurno foi de $19,3 \mathrm{MJ}^{-2} \mathrm{~m}^{-2}$.dia ${ }^{-1}$. Nesse episódio, os valores de $\beta$ variaram de 0,03 às 7 horas até 0,32 às 11 horas. Durante as primeiras horas da manhã, foram obtidos os menores valores de $\beta$, assim como obtido por Gutierrez \& Menzer (1994), sendo que às 6 horas da manhã o valor de $\beta$ foi de $-1,96$, sendo desconsiderado segundo os critérios de Perez et al. (1999), citado por Marin (2003). O total diurno do fluxo de calor latente, 
representou em 10/2/2003, 79,2\% do total do saldo de radiação. Já o fluxo de calor sensível representou $17,6 \%$ do total de SR e o fluxo de calor no solo, $3,2 \%$.

No dia 29/7/2003, durante a estação seca (Figura 10B), o total do saldo de radiação no período diurno foi de $10,8 \mathrm{MJ} \cdot \mathrm{m}^{-2} \cdot \mathrm{dia}^{-1}$. Os valores de $\beta$ variaram de 0,77 , às 7 horas da manhã, a - 0,07 às 18 horas, permanecendo acima de 0,5 em várias horas do dia. A partir das 16 horas, com a diminuição do suprimento de energia os valores de $\beta$ começaram a decrescer. Esse comportamento de $\beta$ aproximou as curvas de $\lambda \mathrm{E}$ e $\mathrm{H}$ durante esse dia (Figura 37B), caracterizando uma limitação do suprimento de água ao processo de evapotranspiração. Nesse episódio, $\lambda E$ representou cerca de $64,3 \%$ do $S R$, enquanto que $\mathrm{H}$ representou $33,4 \%$. Os valores negativos de $\beta$ encontrados nas primeiras horas da manhã ou ao final da tarde, podem ser devidos as limitações dos equipamentos, devido aos gradientes serem muito pequenos nesses horários ou mesmo ocorrência de inversão térmica no início e final do dia, o que faz com que se inverta o sentido do fluxo de calor sensível, invertendo também o sinal de $\beta$.

$\mathrm{Na}$ Tabela 16, é apresentada a variação diária dos componentes do balanço de energia no cultivo consorciado para duas épocas do ano. Na primeira época, as medições foram realizadas na estação chuvosa durante o verão e início de outono, nos meses de dezembro de 2002 e março e abril de 2003 e na segunda época, as medições foram realizadas no período de inverno e primavera nos meses de julho e novembro de 2003.

De uma maneira geral, o comportamento dos componentes do balanço de energia não diferiu muito do cultivo a pleno sol. Analisando a relação $\lambda E / S R$ durante as duas épocas pode se verificar que no verão seu valor médio foi de 0,76 , com valores entre 0,67 a 0,94. Já para o período seco, essa relação foi de 0,73 , com variações entre 0,68 e 0,78 . Por outro lado, a relação $\mathrm{H} / \mathrm{SR}$ foi de 0,23 no verão e de 0,25 no inverno e primavera.

Com relação ao fluxo de calor para o solo, quando se leva em consideração apenas os valores do período diurno, seus valores médios representaram cerca de $1 \%$ do SR no verão e $2 \%$ no período de inverno-primavera. Observando os dados da Tabela 16, verifica-se que no final das medições as relações de FS/SR atingiram até 0,04, provavelmente devido a menor cobertura de solo na entrelinha, por se tratar de um período de final de estiagem. 
Tabela 16. Variação diária dos valores de saldo de radiação (SR), fluxo de calor latente $(\lambda E)$, fluxo de calor sensível $(H)$ e fluxo de calor para o solo (FS) $\left(\mathrm{MJ} \cdot \mathrm{m}^{-2} \cdot \mathrm{dia}^{-1}\right)$, em período diurno, e relações de $\lambda E, H$ e FS com SR, durante duas épocas do ano, em cultivo de café consorciado com banana 'Prata Anã', em Mococa, SP

\begin{tabular}{|c|c|c|c|c|c|c|c|c|}
\hline \multirow{2}{*}{ Época } & \multirow{2}{*}{ Dia } & SR & $\lambda \mathrm{E}$ & $\mathrm{H}$ & FS & \multirow{2}{*}{$\lambda \mathrm{E} / \mathrm{SR}$} & \multirow{2}{*}{$\mathrm{H} / \mathrm{SR}$} & \multirow{2}{*}{$\mathrm{FS} / \mathrm{SR}$} \\
\hline & & \multicolumn{4}{|c|}{$\mathrm{MJ} \cdot \mathrm{m}^{-2} \cdot \mathrm{dia}^{-1}$} & & & \\
\hline \multirow[t]{16}{*}{ Chuvosa } & $11 / 12 / 2002$ & 7,8 & $-6,6$ & $-1,2$ & 0,0 & 0,84 & 0,16 & 0,00 \\
\hline & $12 / 12 / 2002$ & 9,4 & $-7,2$ & $-1,9$ & $-0,4$ & 0,76 & 0,20 & 0,04 \\
\hline & $13 / 12 / 2002$ & 15,1 & $-11,4$ & $-3,1$ & $-0,6$ & 0,76 & 0,21 & 0,03 \\
\hline & $14 / 12 / 2002$ & 11,9 & $-8,9$ & $-2,8$ & $-0,3$ & 0,74 & 0,24 & 0,02 \\
\hline & $15 / 12 / 2002$ & 12,8 & $-8,9$ & $-3,5$ & $-0,3$ & 0,70 & 0,28 & 0,02 \\
\hline & 16/12/2002 & 3,3 & $-3,1$ & $-0,6$ & 0,4 & 0,94 & 0,18 & $-0,12$ \\
\hline & 27/3/2003 & 9,2 & $-7,0$ & $-2,0$ & $-0,2$ & 0,76 & 0,22 & 0,02 \\
\hline & 28/3/2003 & 17,3 & $-11,5$ & $-5,3$ & $-0,4$ & 0,67 & 0,31 & 0,02 \\
\hline & 29/3/2003 & 16,5 & $-12,0$ & $-3,9$ & $-0,5$ & 0,73 & 0,24 & 0,03 \\
\hline & $30 / 3 / 2003$ & 16,2 & $-12,1$ & $-3,6$ & $-0,5$ & 0,75 & 0,22 & 0,02 \\
\hline & $16 / 4 / 2003$ & 13,2 & $-9,6$ & $-3,4$ & $-0,2$ & 0,73 & 0,26 & 0,01 \\
\hline & $17 / 4 / 2003$ & 14,6 & $-10,7$ & $-3,7$ & $-0,3$ & 0,73 & 0,25 & 0,02 \\
\hline & $18 / 4 / 2003$ & 14,1 & $-10,7$ & $-3,1$ & $-0,3$ & 0,76 & 0,22 & 0,02 \\
\hline & $19 / 4 / 2003$ & 12,5 & $-9,4$ & $-2,7$ & $-0,4$ & 0,75 & 0,22 & 0,03 \\
\hline & $20 / 4 / 2003$ & 11,1 & $-8,7$ & $-2,1$ & $-0,3$ & 0,78 & 0,19 & 0,03 \\
\hline & Média & 12,3 & $-9,2$ & $-2,9$ & $-0,3$ & 0,76 & 0,23 & 0,01 \\
\hline \multirow[t]{11}{*}{ Seca } & 2/7/2003 & 10,6 & $-7,3$ & $-3,3$ & 0,0 & 0,68 & 0,31 & 0,01 \\
\hline & 3/7/2003 & 10,7 & $-7,3$ & $-3,3$ & $-0,1$ & 0,68 & 0,31 & 0,01 \\
\hline & 4/7/2003 & 10,8 & $-8,5$ & $-2,2$ & $-0,1$ & 0,78 & 0,21 & 0,01 \\
\hline & 8/7/2003 & 10,8 & $-8,4$ & $-2,3$ & $-0,2$ & 0,77 & 0,21 & 0,02 \\
\hline & 9/7/2003 & 10,6 & $-8,3$ & $-2,2$ & $-0,2$ & 0,78 & 0,21 & 0,01 \\
\hline & $6 / 11 / 2003$ & 11,8 & $-8,7$ & $-2,9$ & $-0,2$ & 0,74 & 0,25 & 0,01 \\
\hline & $7 / 11 / 2003$ & 15,0 & $-11,1$ & $-3,6$ & $-0,3$ & 0,74 & 0,24 & 0,02 \\
\hline & 8/11/2003 & 20,0 & $-14,2$ & $-5,2$ & $-0,6$ & 0,71 & 0,26 & 0,03 \\
\hline & $9 / 11 / 2003$ & 19,8 & $-14,2$ & $-4,8$ & $-0,8$ & 0,72 & 0,24 & 0,02 \\
\hline & $10 / 11 / 2003$ & 18,3 & $-12,5$ & $-5,0$ & $-0,8$ & 0,68 & 0,28 & 0,04 \\
\hline & Média & 13,8 & $-10,0$ & $-3,5$ & $-0,3$ & 0,73 & 0,25 & 0,02 \\
\hline
\end{tabular}


$\mathrm{Na}$ Figura 38, é apresentada a variação horária durante o período diurno dos componentes do balanço de energia no cultivo consorciado de café com banana 'Prata Anã' nos dias 13/12/2002 (Figura 38A), característico da estação chuvosa e do dia 3/7/2003 (Figura 38B), característico da estação seca.
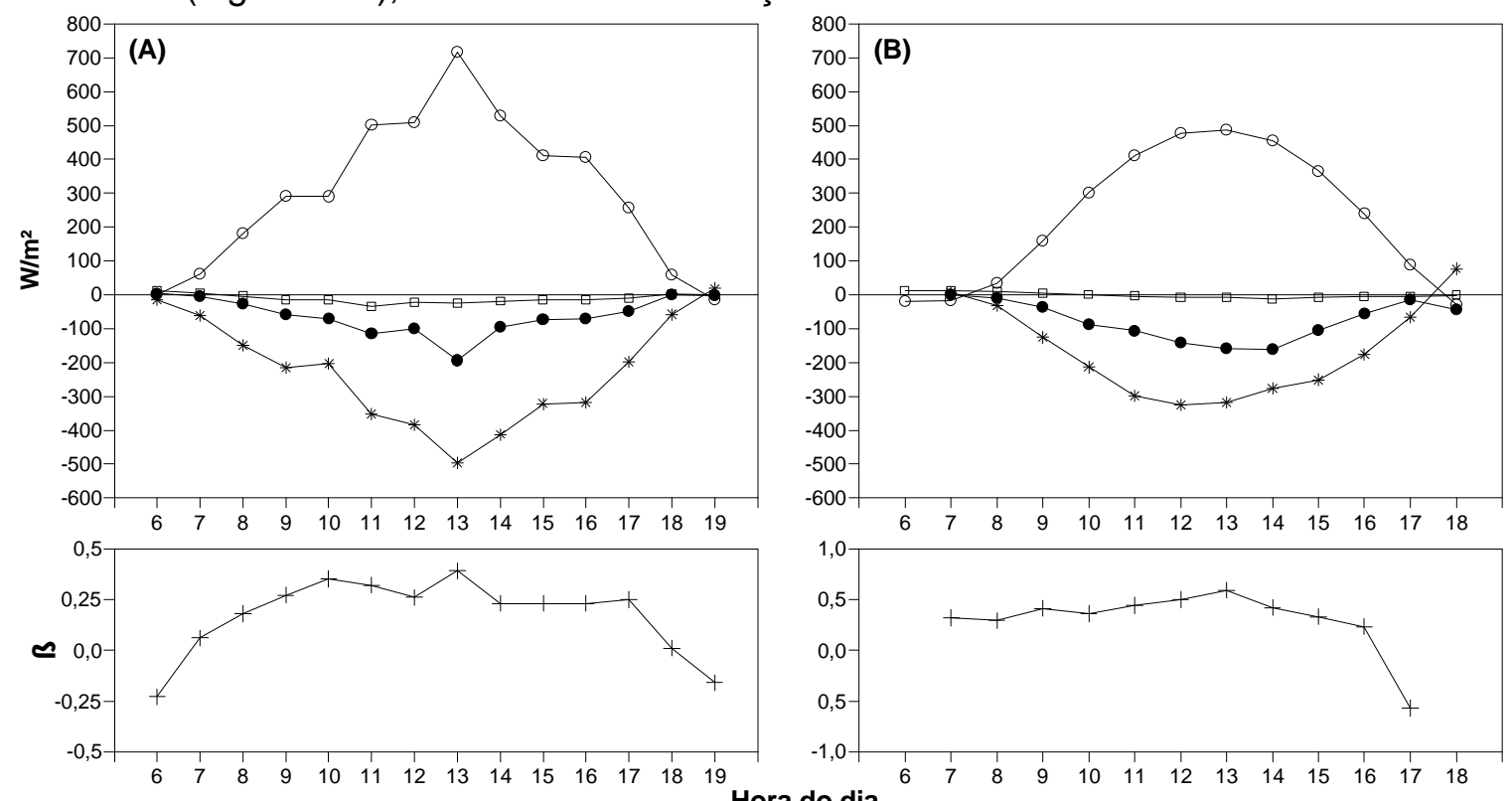

$$
\begin{gathered}
\text { Hora do dia } \\
-\odot \mathrm{SR} * \mathrm{LE} \bullet \mathrm{H}-\square \mathrm{FS} \\
\hline
\end{gathered}
$$

Figura 38 - Variação horária do saldo de radiação (SR), do fluxo de calor latente (LE), do fluxo de calor sensível (H), do fluxo de calor no solo (FS) e da razão de Bowen (B) nos dias 13/12/2002 (A) e 3/7/2003 (B), em cultivo de café consorciado com banana 'Prata Anã', em Mococa, SP

No dia 13/12/2002 (Figura 38A), os valores de $\beta$ variaram de $-0,23$, às 6 horas da manhã a 0,39 às 13 horas. É bom ressaltar que apesar desse dia apresentar elevado valor de SR (15,1 MJ.m $\left.{ }^{-2} \cdot \mathrm{dia}^{-1}\right)$, ocorreram alguns períodos de nebulosidade, o que pode ter reduzido os valores de $\beta$, contudo, os valores de $\beta$ se mostraram um pouco superiores aos encontrados para um dia de verão no cultivo a pleno sol. No dia 13/12/2002, o fluxo de calor latente representou $75,7 \%$ do saldo de radiação, enquanto que $\mathrm{H}$ representou $20,6 \%$.

No dia 3/7/2003 (Figura 38B), representativo de período seco, o valor de $\beta$ atingiu 0,59 às 14 horas, permanecendo próximo de 0,5 na maior parte do dia. Assim como ocorrido em episódio do cultivo a pleno sol o valor de $\beta$ às 6 horas da manhã foi menor que $-0,75$, sendo desconsiderado. Os maiores valores de $\beta$ em relação ao episódio de verão, fez com que o fluxo de calor latente representasse $68 \%$ do saldo de radiação. Por outro 
lado, devido a restrição hídrica, o fluxo de calor sensível representou $31 \%$ do saldo de radiação. Outro fator que pode ter contribuído para esse aumento na relação H/SR nesse dia em relação ao período de verão foi a pouca incidência de vento (Figura 29A).

Na Figura 39 é apresentada a relação entre a evapotranspiração de referência (ETo), obtida no posto meteorológico situado próximo ao experimento e a evapotranspiração real dos cultivos, que é representada pelo fluxo de calor latente obtido no balanço de energia.
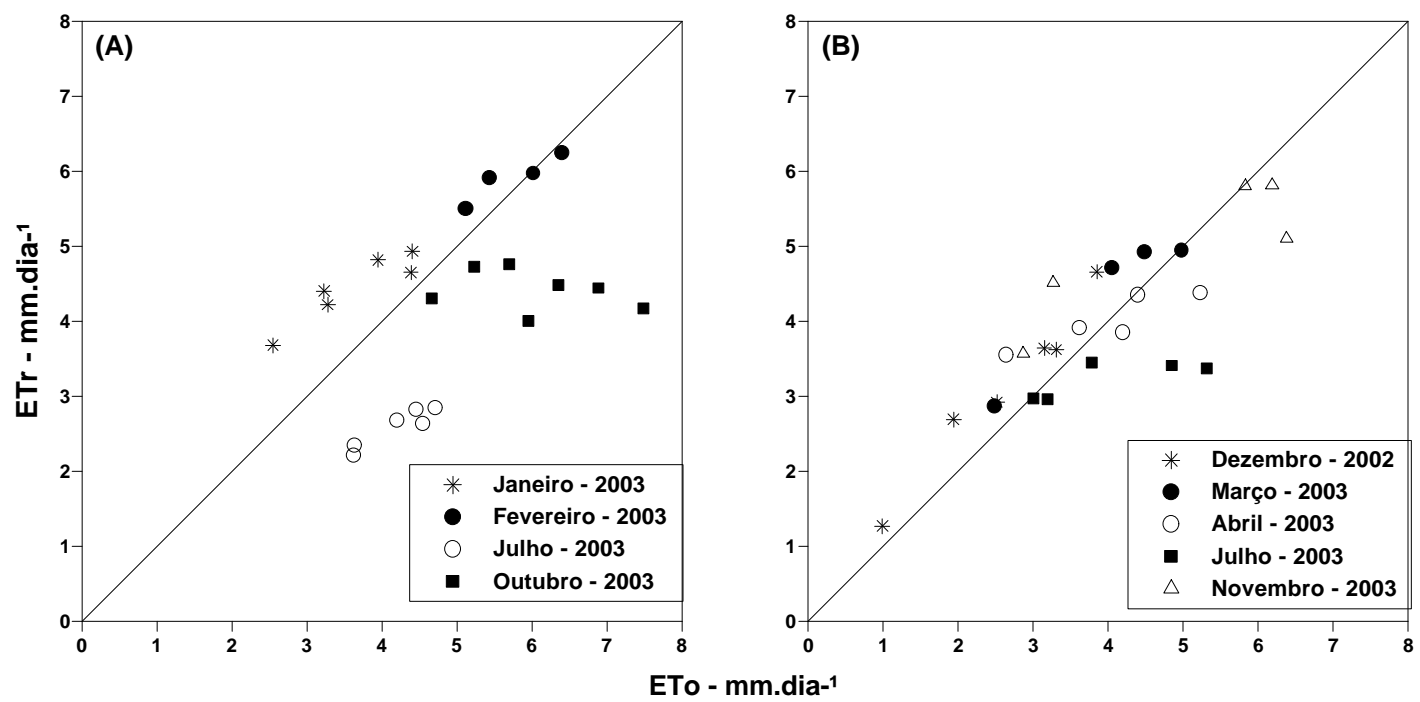

Figura 39 - Relação entre a evapotranspiração de referência (ETo) e a evapotranspiração da cultura (Etr), para o cultivo a pleno sol (A) e o cultivo consorciado (B) em diferentes épocas do ano

Apesar dos valores médios dos componentes do balanço de energia nos dois sistemas de cultivos não apresentarem diferenças, tanto para o período chuvoso quanto para o período seco (Tabelas 15 e 16), quando analisada a relação Etr/Eto para as diferentes épocas do ano, essa tendência não é observada, verificando-se comportamento distinto dos sistemas de cultivo, principalmente nos episódios durante o período seco.

Nas medições do período úmido no cultivo a pleno sol, durante os meses de janeiro e fevereiro de 2003, quando não havia restrição hídrica, os valores de Etr foram: superiores a Eto para dias com demandas atmosférica de até $4 \mathrm{~mm}$; próximos a Eto em dias com demandas entre 4 e $6 \mathrm{~mm}$ e ligeiramente inferiores em dias com demandas atmosféricas superiores a 6 mm (Figura 39A). Já nos episódios de julho e outubro de 2003 
no cultivo a pleno sol, os valores de Etr permaneceram abaixo dos valores de Eto, tanto para dias com baixa ou alta demanda, evidenciando uma restrição no processo de evapotranspiração devido a limitação hídrica da época do ano, aumentando a relação de H/Sr nesses episódios (Tabela 15).

Para o cultivo consorciado (Figura 39B), a relação de ETr/ETo para os episódios de julho e novembro, durante o período seco, apresentou valores mais próximos à unidade, mesmo em dias com alta demanda atmosférica, próximo de $7 \mathrm{~mm}$. Para 0 período úmido, nas medições realizadas nos meses de dezembro de 2002 e em março e abril de 2003, os valores de Etr permaneceram próximos ou superiores a ETo.

O comportamento diferenciado das relações de ETr/Eto, nos dois sistemas de cultivo, principalmente no período seco, pode ter sido influenciado pela contribuição da transpiração das bananeiras na evapotranspiração da cultura no sistema consorciado.

Outra razão para a diferença na relação Etr/Eto entre os dois cultivos pode estar relacionada às características de origem do café arábica, planta proveniente dos altiplanos da Etiópia, região de sub-bosques, com comportamento de transpiração sensível ao défice de pressão de vapor e vento. No cultivo a pleno sol, além da restrição hídrica decorrente do período seco, os altos valores de défice de pressão de vapor (episódios de julho de 2003) e a alta incidência de vento (episódios de outubro de 2003) (Figura 27B), podem ter influenciado a evapotranspiração da cultura, em decorrência de alterações no seu comportamento em função desses fatores ambientais (Marin et al., 2004), fatores esses que foram minimizados no cultivo consorciado.

\subsection{Crescimento, fenologia e produção dos cafeeiros}

\subsubsection{Crescimento dos cafeeiros}

$\mathrm{Na}$ Figura 40, são apresentados os valores médios da evolução da altura das plantas e diâmetro da copa de quatro pontos amostrais do cultivo de café consorciado com banana 'Prata Anã', bem como sua média e no cultivo de café a pleno sol. 

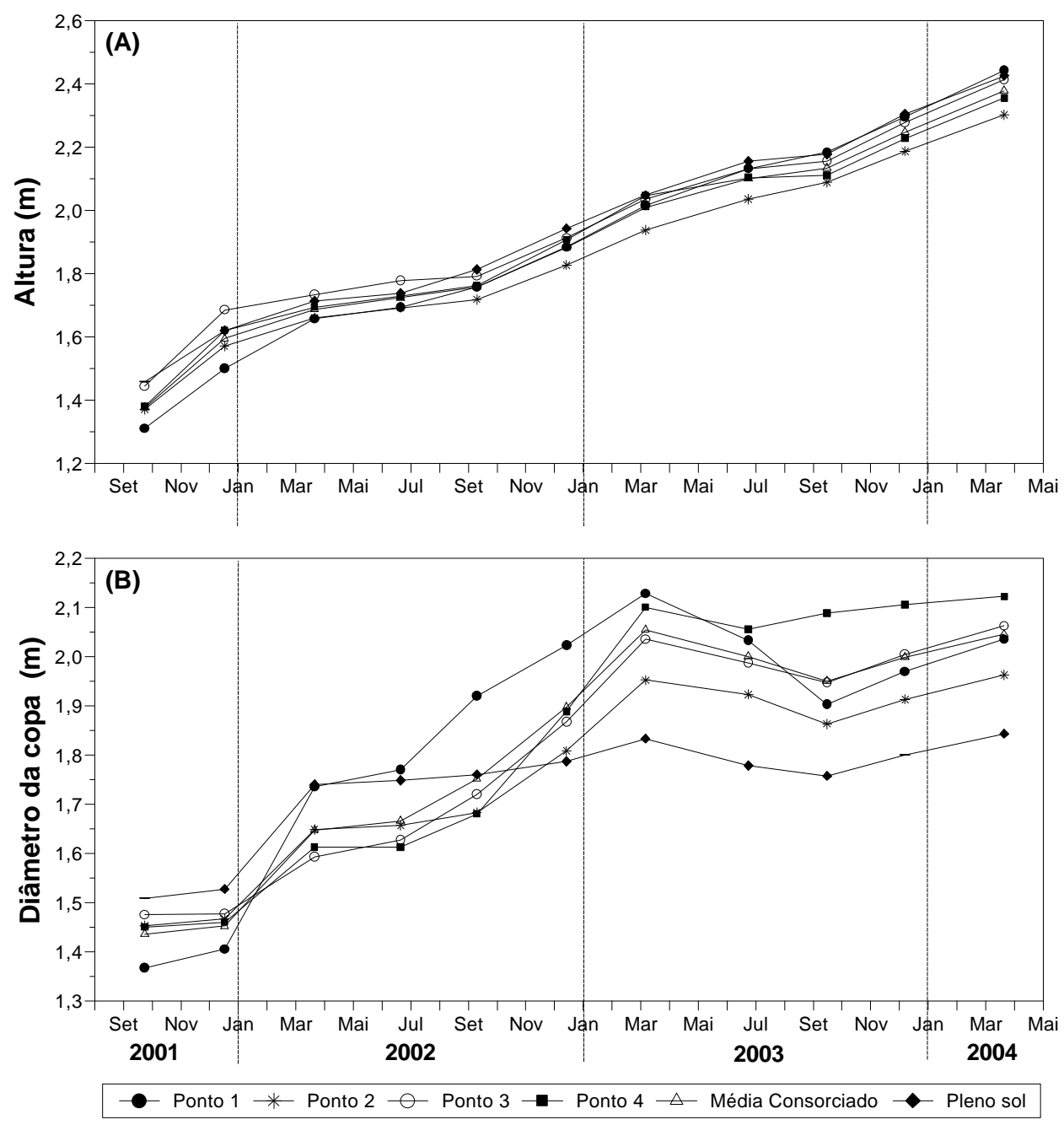

Figura 40 - Crescimento médio em altura $(A)$ e diâmetro da copa $(B)$ em quatro pontos amostrais de cultivo de café consorciado com banana 'Prata Anã', bem como sua média, e em cultivo de café a pleno sol, durante os meses de setembro de 2001 a abril de 2004

No início das medições, em setembro de 2001, os cafeeiros apresentavam cerca de $1,4 \mathrm{~m}$ de altura e no final das medições, em abril de 2004 , cerca de $2,4 \mathrm{~m}$ de altura (Figura 40A). Observando a Figura 40A, verifica-se que a evolução da altura se manteve próxima entre os diferentes pontos amostrais do sistema consorciado, sua média e o cultivo de café a pleno sol. Apenas o ponto amostral 2 do sistema consorciado apresentou menores valores absolutos em relação aos outros pontos amostrais no período de setembro de 2002 a setembro de 2003. 
Com relação ao diâmetro da copa, o comportamento entre os pontos amostrais foi diferenciado. No cultivo a pleno sol, seus valores médios estabilizaram em cerca de 1,8m a partir de março de 2002. Já no cultivo consorciado o ponto amostral 1 apresentou maiores valores absolutos entre julho de 2002 e março de 2003 em relação ao outros pontos amostrais dos sistema consorciado. Isso fez com que o comportamento média das plantas do sistema consorciado apresentasse maiores valores absolutos de diâmetro de copa em relação ao cultivo a pleno sol nos anos de 2003 e 2004.

$\mathrm{Na}$ Figura 41, são apresentados as variações estacionais do crescimento de plantas em altura (Figura 41A) e diâmetro de copa (Figura 41B) e na Figura 42 são apresentados os intervalos de confiança (95\%) durante cinco períodos de medição de altura (Figura 42A a 42E) e diâmetro de copa (Figura 42F a 42J).

Observando a Figura 41A, verifica-se que as intensidades de crescimento em altura foram maiores no período primavera-verão em relação ao período de outonoinverno, sendo que o período de 26/3/2002 a 17/9/2002 apresentou as menores taxas de crescimento $\left(0,04 \mathrm{~cm} \cdot \mathrm{dia}^{-1}\right.$ no cultivo consorciado e $0,05 \mathrm{~cm} \cdot \mathrm{dia}^{-1}$ no cultivo a pleno sol), devido a ocorrência de um grande período com deficiência hídrica na região de Mococa nesse período (Figura 10A). Variações estacionais do crescimento de cafeeiros com padrões semelhantes nas regiões cafeeiras tradicionais também foram encontrados por Barros \& Maestri (1974) e Libardi et al. (1995), entre outros.

Ainda com relação a altura dos cafeeiros, não houve diferença entre os padrões sazonais de crescimento em altura entre os pontos amostrais do sistema consorciado e no cultivo a pleno sol. Observando a análise de intervalo de confiança para o crescimento em altura nos cinco períodos de medida (Figura 42A a 42E), pode-se verificar que não houve diferença estatística entre nenhum ponto amostral em qualquer época de medida, embora o ponto 1 do sistema consorciado tenha apresentado maiores taxas de crescimento em relação aos outros pontos amostrais no primeiro ano de medidas (Figura 42A e 42B). 

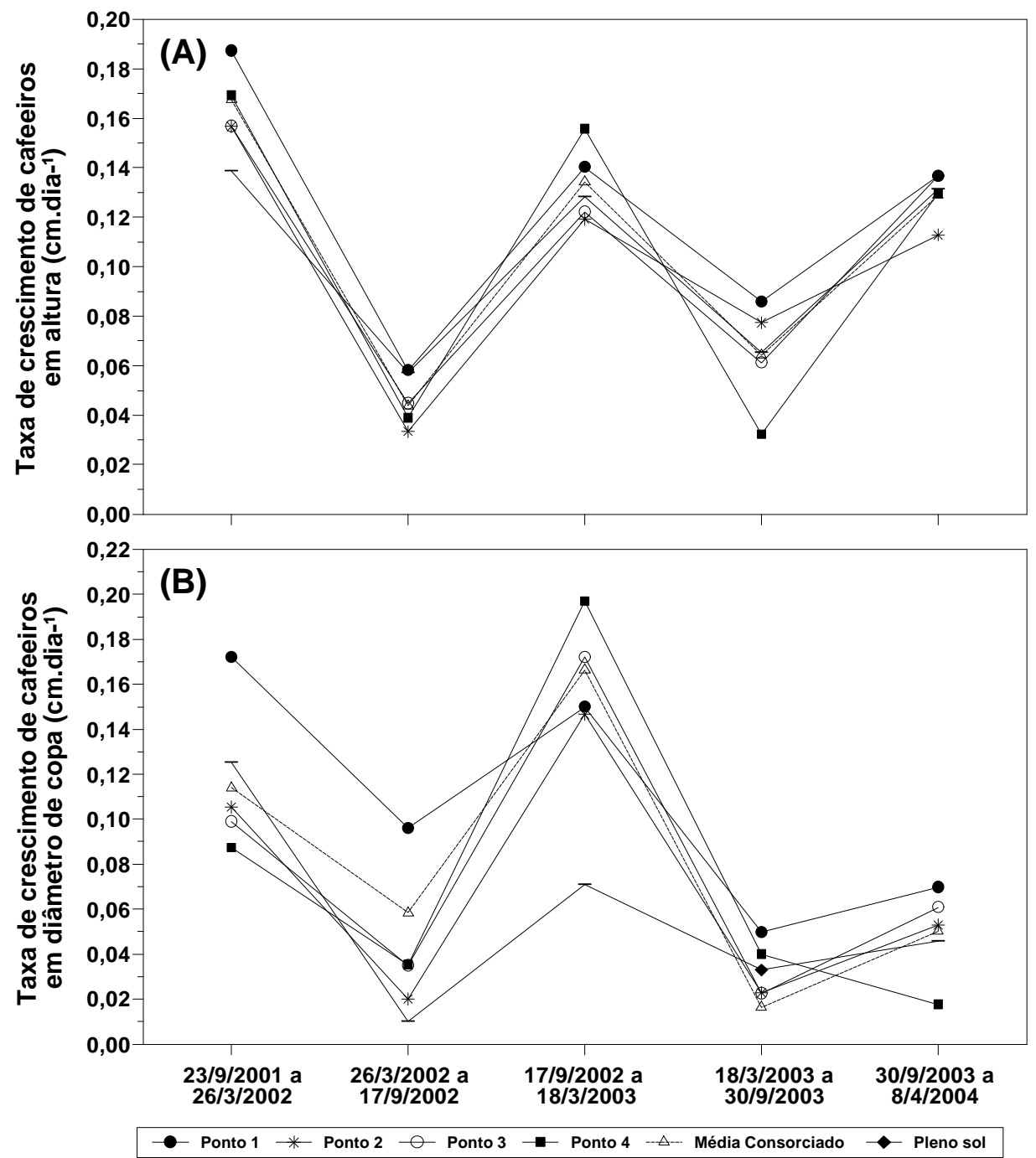

Figura 41 - Taxas de crescimento em altura do ramo plagiotrópico (A) e diâmetro máximo da copa (B) de cafeeiros em quatro pontos de amostragem em cultivo consorciado de café com banana 'Prata Anã', bem como sua média e em cultivo de café a pleno sol, em cinco períodos, em Mococa, SP 

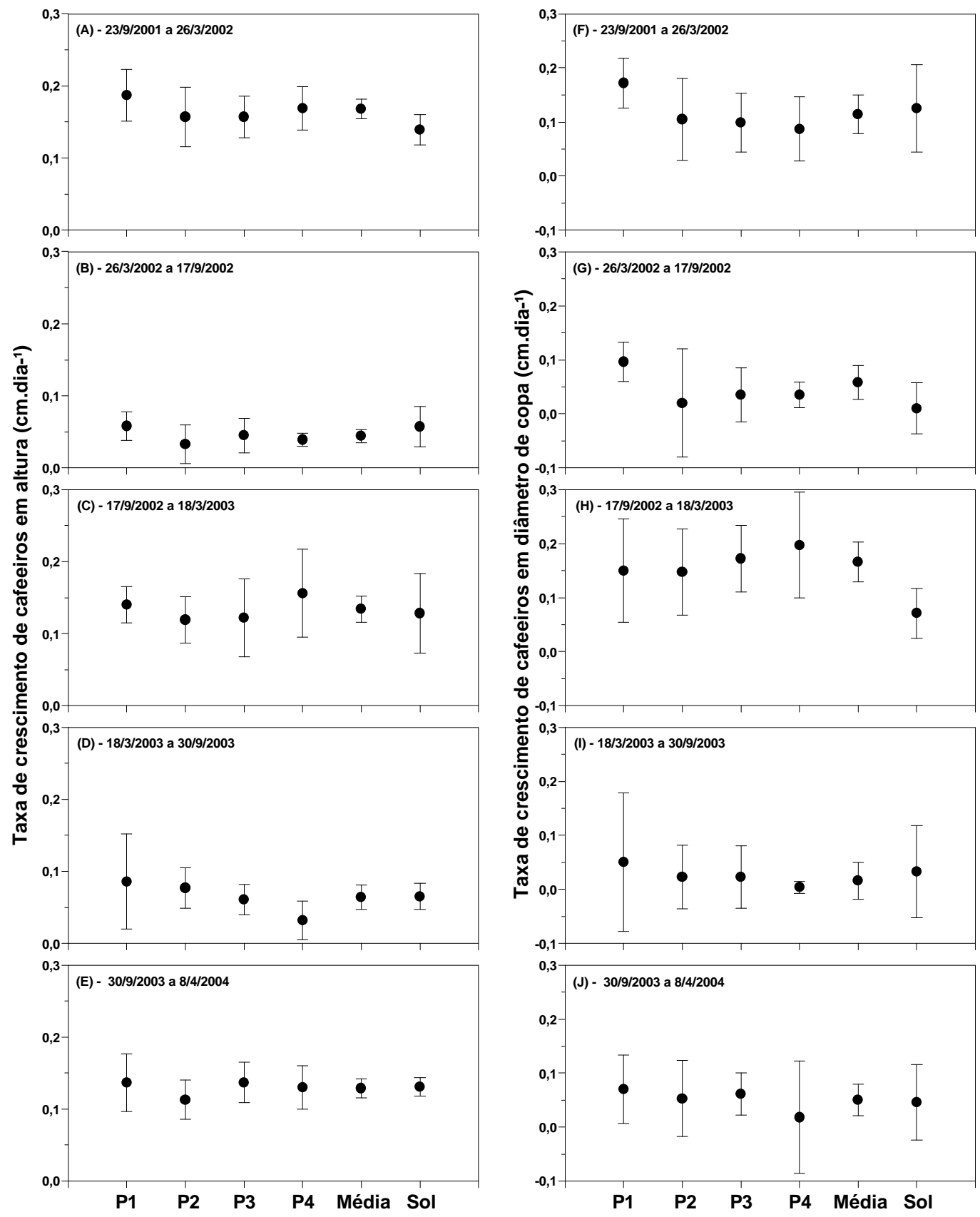

Figura 42 - Intervalos de confiança para taxas de crescimento em altura do ramo plagiotrópico ( $A$ a $E$ ) e diâmetro máximo da copa ( $F$ a J) de cafeeiros em quatro pontos de amostragem em cultivo consorciado de café com banana 'Prata Anã' (P1 a P4), bem como sua média e em cultivo de café a pleno sol (Sol), em cinco períodos, em Mococa, SP 
O ponto amostral 1 do sistema consorciado foi o que apresentou maior interceptação da radiação solar global (Figura 11), o que pode ter influenciado as maiores taxas no primeiro ano de medidas. Quando o sombreamento dos cafeeiros é mais intenso, ocorre indução ao maior crescimento em altura, como verificado por Morais et al. (2003). Esses autores, assim como Fahl et al. (1994) e Carelli et al. (1999) atribuem esse comportamento a um mecanismo denominado estiolamento, que otimiza a captura de luz.

Quando analisado o diâmetro da copa (Figura 41B), verifica-se que a variação estacional de seu crescimento apresentou-se semelhante a altura nas quatro primeiras medições. Na quinta medição (30/9/2003 a 8/4/2004), embora em se tratando de um período chuvoso, as taxas permaneceram baixas $\left(0,05 \mathrm{~cm}_{\text {.dia }}{ }^{-1} \mathrm{em}\right.$ média) para todos os pontos amostrais, provavelmente devido ao crescimento dos ramos plagiotrópicos primários já terem atingido seus valores máximos ou ainda por uma questão da relação fonte-dreno do cafeeiro, em se tratar de uma época do ano onde estava ocorrendo desenvolvimento dos frutos (Ortolani et al., 1970).

Com relação ao comportamento dos diferentes pontos amostrais, verificou-se que P1 do sistema consorciado apresentou maiores taxas de crescimento em diâmetro no primeiro ano de medições, sendo que no segundo período de medidas (Figura 42G), sua taxa foi significativamente maior do que os cafeeiros conduzidos a pleno sol. A partir do terceiro período de medições, as plantas do cultivo a pleno sol apresentaram as menores taxas de crescimento, sendo que na primavera-verão de 2003, os valores de crescimento em diâmetro diferiram significativamente, pelo critério do intervalo de confiança, em relação à média dos cafeeiros cultivado em consórcio (Figura 42H). Para as demais épocas, as taxas de crescimento do diâmetros da copa não diferiram entre si (Figura 42I e 42J).

\subsubsection{Desenvolvimento fenológico}

$\mathrm{Na}$ Figura 43 é apresentado o desenvolvimento fenológico, para a florada principal, entre as fases de gema dormente e grão seco dos cafeeiros (Anexo A), em quatro pontos amostrais do cultivo de café consorciado com banana 'Prata Anã', bem como sua média e no cultivo de café a pleno sol nos anos agrícolas de 2001/2002, 2003/2003 e 2003/2004. 

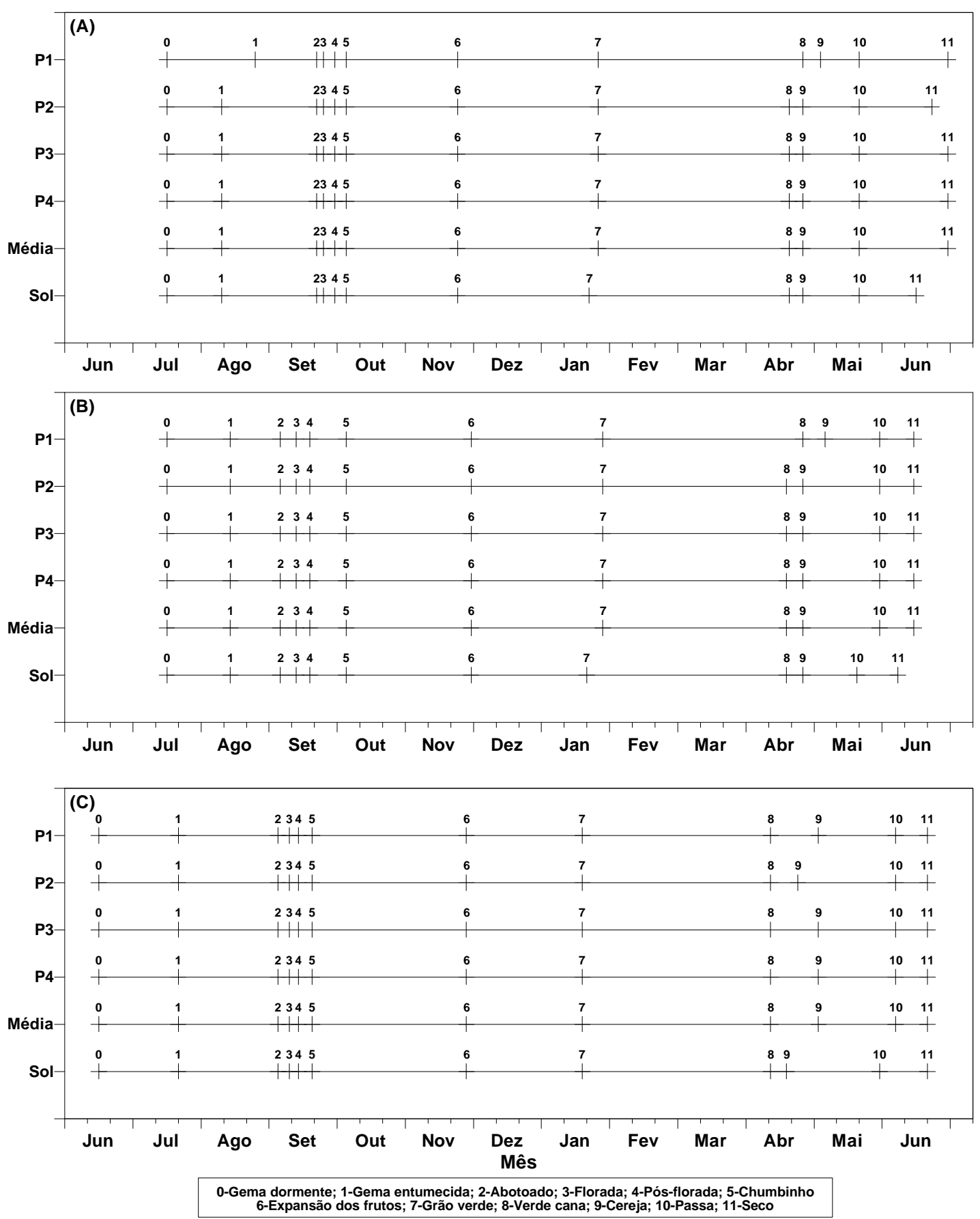

Figura 43 - Épocas de ocorrência de estádios fenológicos de cafeeiro, para a florada principal, em quatro pontos do amostragem em cultivo consorciado de café com banana 'Prata Anã' (P1 a P4), bem como sua média e no cultivo de café a pleno sol (Sol) nos anos agrícolas de 2001/2002 (A), 2002/2003 (B) e 2003/2004 (C) 
No ano agrícola 2001/2002 (Figura 43A), quando analisado o desenvolvimento fenológico do cultivo de café a pleno sol, verifica-se que no inicio de agosto de 2001, as plantas já se apresentavam na fase de gema entumecida (fase 1), devido a ocorrência de chuvas no final de julho. Apesar de se verificar ocorrência de chuvas no final de agosto (Figura 10A e Anexo B), não ocorreu indução ao florescimento, que só veio ocorrer no final de setembro. Segundo Camargo et al. (2001), as gemas estão aptas para o florescimento quando acumulados cerca de $350 \mathrm{~mm}$ de ETo a partir do inicio de abril, o que para o ano de 2001 em Mococa só ocorreu a partir do meio do mês de setembro. Após a florada, sucederam-se as fases chumbinho (5) e expansão dos frutos (6), até meados de janeiro, quando foi iniciada a granação (grão verde - 7), até o início da maturação (cereja), que ocorreu no final de abril. A duração da fase cereja na safra de 2001/2002 teve duração de cerca de 20 dias, período relativamente curto, devido principalmente a ocorrência de elevadas temperaturas nos meses de abril e maio de 2002 (Anexo B) em comparação com os dados normais da região (Figura 2A).

Ao comparar o desenvolvimento fenológico médio dos cafeeiros do cultivo consorciado e do cultivo a pleno sol na safra de 2001/2002, só foram verificadas diferenças na mudança de fase de expansão de frutos (6) para grão verde (7), em cerca de 7 dias e na mudança de fase de passa (10) para seco (11), em cerca de 14 dias. Analisando a variabilidade do desenvolvimento fenológico dentro do sistema consorciado, verificou-se que o ponto amostral 1 diferenciou-se dos demais no estabelecimento da fase gema entumecida (1), com atraso em cerca de 15 dias e na maturação (fases verde cana e cereja) dos frutos, com atraso de 7 dias.

Analisando o desenvolvimento fenológico do cultivo de café a pleno sol no ano agrícola 2002/2003 (Figura 43B), verifica-se que a ocorrência de chuvas no início de agosto de 2002 induziu o desenvolvimento das gemas para a fase de gema entumecida (fase 1) e que a ocorrência de chuvas mais significativas no final de agosto (cerca de 40 $\mathrm{mm}$ ) provocou o florescimento dos cafeeiros no inicio de setembro. Diferentemente do ano anterior, no final de agosto já se tinham sido acumulados cerca de $400 \mathrm{~mm}$ de Eto a partir do inicio de abril, devido a ocorrência de um outono e inverno mais quente que o normal para a região. De uma maneira geral a sucessão das fases posteriores, no cultivo a pleno sol, se deu de maneira semelhante ao ano anterior, ocorrendo a fase de grão seco no inicio de junho de 2003. 
No ano agrícola de 2002/2003 (Figura 42B), verificaram-se diferenças entre os sistemas de cultivo de café a pleno sol e consorciado, na mudança de fase de expansão de frutos (6) para grão verde (7), em cerca de 10 dias e na mudança de fase de cereja (9) para passa (10), em cerca de 10 dias. Com relação a variabilidade do desenvolvimento fenológico dentro do sistema consorciado, o ponto amostral 1 diferenciou-se dos demais no estabelecimento da maturação (fases verde cana e cereja) dos frutos, com atraso de 10 dias, assim como no ano anterior.

No ano agrícola 2003/2004 (Figura 43C), quando analisado o desenvolvimento fenológico do cultivo de café a pleno sol, verificou-se que no mês de julho de 2003, as plantas já se apresentavam na fase de gema entumecida (fase 1), devido a ocorrência de chuvas. O estímulo à florada principal somente ocorreu no final de agosto, quando foram verificadas chuvas na região. O florescimento principal ocorreu no primeiro decêndio de setembro e a sucessão das demais fases culminou com a maturação (cereja) no final de abril de 2004. A ocorrência de um outono com temperaturas mais baixas que o normal, além da ocorrência de chuvas em abril e maio, determinaram uma duração da fase cereja no cultivo a pleno sol em torno de 40 dias.

Quando comparados o desenvolvimento fenológico médio dos cafeeiros do cultivo consorciado e do cultivo a pleno sol na safra de 2003/2004, foram verificadas diferenças no estabelecimento da maturação (cereja) dos frutos, com atraso de 14 dias no cultivo consorciado a exceção do ponto amostral 2, onde foi verificado um atraso de 5 dias. A duração da fase cereja no cultivo consorciado foi em torno de 35 dias.

Analisando o desenvolvimento fenológico dos 3 anos agrícolas, verificou-se que no estabelecimento do florescimento, não houve diferenças entre os cultivos. As condições macroclimáticas, como a ocorrência de períodos com temperaturas elevadas ou amenas, além da ocorrência de chuvas, durante a fase de desenvolvimento e maturação das gemas determinaram a ocorrência dos estádios fenológicos nas mesmas datas para os cultivos a pleno sol e consorciado, não sendo verificadas também diferenças entre os pontos amostrais do sistema consorciado.

Com relação a maturação dos frutos, quando analisados os três anos agrícolas, algumas diferenças foram verificadas, como maior duração da fase passa no cultivo consorciado no ano agrícola 2001/2002, maior duração da fase cereja no cultivo consorciado no ano agrícola 2002/2003 e maior duração da fase grão-verde no ano agrícola 2003/2004. Segundo Camargo \& Pereira (1994), o maior tempo verificado na 
maturação dos grãos, além da maior duração da fase cereja, pode se traduzir em uma boa vantagem para o agricultor, permitindo maior tempo para realizar a colheita seletiva.

Com relação a variabilidade espacial do desenvolvimento fenológico dentro do sistema consorciado, o ponto amostral 1 demorou mais tempo para atingir a maturação dos frutos nos anos agrícolas de 2001/2002 e 2002/2003, não sendo verificadas diferenças no tempo de maturação entre esse ponto amostral e a maioria dos outros pontos no ano agrícola 2003/2004.

\subsection{3 Índices de produção}

\subsubsection{1 Índices de produção nos cultivos de café a pleno sol e consorciado com banana 'Prata Anã'}

Na Tabela 17 são apresentados os valores médios de produção, em café da roça, nas parcelas de $320 \mathrm{~m}^{2}$ dos sistemas de produção de café a pleno sol e consorciado com banana 'Prata Anã' nos anos de 2002, 2003 e 2004, bem como o total acumulado dos três anos. São apresentados ainda os dados médios de rendimento de café (\%) e massa de 100 sementes para os três anos, bem como sua média.

$\mathrm{Na}$ Figura 44 são apresentados, além dos valores médios da produção das três safras, o resultado da análise estatística de intervalo de confiança (95\%). Nas Figuras 45 e 46 são apresentados os resultados da análise de intervalo de confiança para as variáveis rendimento e massa de 100 sementes em cada uma das três safras.

Observando os dados de produção da Tabela 17 e da Figura 44, verifica-se que a produção média dos dois sistemas de cultivo não diferiu estatisticamente, pela análise de intervalo de confiança, em nenhuma das três safras, sendo que as colheitas de 2002 e 2004 proporcionaram maiores produções de café da roça. Nas duas primeiras safras, a produção do sistema a pleno sol superou o sistema consorciado, enquanto que na safra de 2004, quando o sistema consorciado apresentou a maior produção dos três anos analisados, essa superou em cerca de $20 \%$ a produção do cultivo a pleno sol.

De certa maneira, o comportamento fenológico do cafeeiro nas condições climáticas do Brasil, apresentado por Ortolani et al (1970), onde os autores relatam que na fase construtiva, que ocorre no período chuvoso, existe uma competição entre o crescimento vegetativo e o processo de produção, pode explicar maiores taxas de crescimento em altura e diâmetro no cultivo consorciado (Figura 42A, 42C e 42H) e 
menores produções nos dois primeiros anos analisados para esse cultivo, em relação ao cultivo a pleno sol.

A safra de 2003 apresentou as menores produções para os dois sistemas de cultivo. Um dos fatores que afetaram a produção de café em 2003 foi a seca ocorrida na região no ano de 2002 (Figura 10), que prejudicou desde a diferenciação das gemas, no início de março, até o início da expansão dos frutos, em novembro.

A grande variabilidade da produção das parcelas, apresentando elevados valores de intervalo de confiança, principalmente no ano de 2002, pode ser atribuída ao fato desse ter sido o primeiro ano de produção das lavouras.

Tabela 17. Produção de café ( $\mathrm{kg}$ de café da roça/320 $\mathrm{m}^{2}$ ), rendimento (\%) e massa de 100 sementes (gramas) em cultivo de café a pleno sol e consorciado com banana 'Prata Anã' nos anos de 2002, 2003 e 2004, em Mococa, SP

\begin{tabular}{lcccc}
\hline Tratamento/Ano & 2002 & 2003 & 2004 & $2001-2004$ \\
\hline \multirow{2}{*}{ Pleno sol } & 92,9 & \multicolumn{4}{c}{ Produção $($ Kg de café roça/320m²) } \\
Consorciado & 83,7 & 17,1 & 84,6 & 194,6 \\
& & & 102,7 & 196,6 \\
Pleno sol & 45,6 & 43,6 & 44,6 & 44,6 \\
Consorciado & 45,8 & 41,3 & 41,9 & 43,0 \\
& & Massa de 100 sementes (gramas) & \\
Pleno sol & 12,6 & 12,7 & 13,9 & 13,1 \\
Consorciado & 12,8 & 13,7 & 13,7 & 13,4 \\
\hline
\end{tabular}




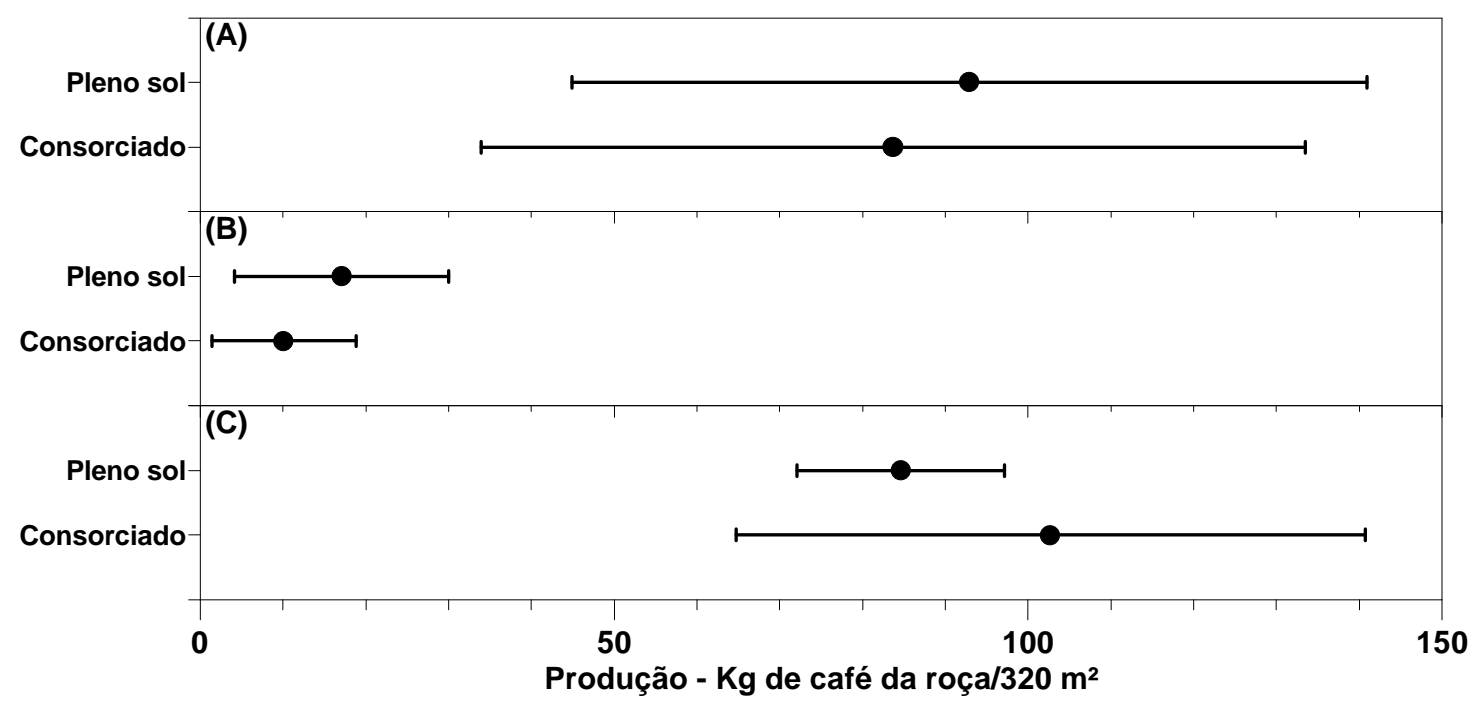

Figura 44 -Produção de café, expressa em kg de café da roça por $320 \mathrm{~m}^{2}$, e intervalos de confiança $(95 \%)$, para os sistemas de produção de café a pleno sol e consorciado com banana 'Prata Anã' nos anos de 2002 (A), 2003 (B) e 2004 (C), em Mococa, SP

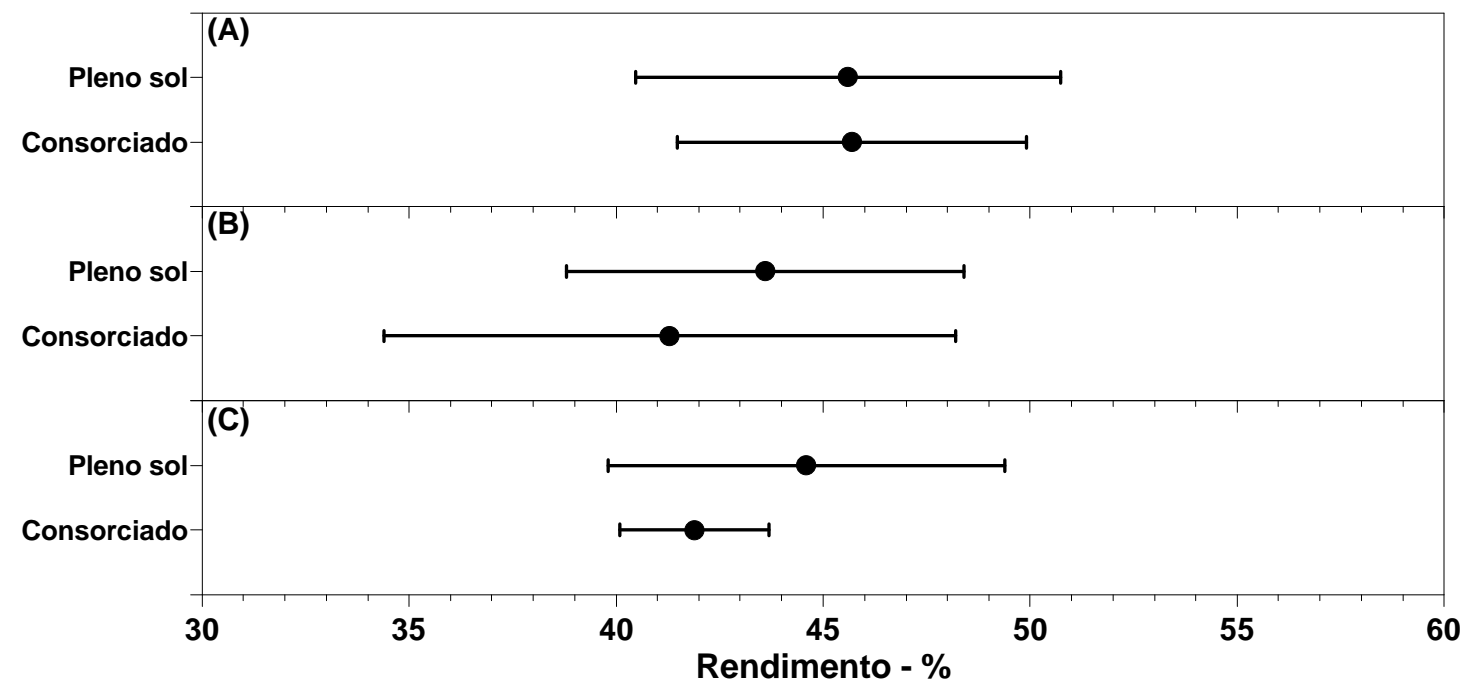

Figura 45 - Rendimento do café (\%) e intervalos de confiança (95\%), para os sistemas de produção de café a pleno sol e consorciado com banana 'Prata Anã' nos anos de 2002 (A), 2003 (B) e 2004 (C), em Mococa, SP 


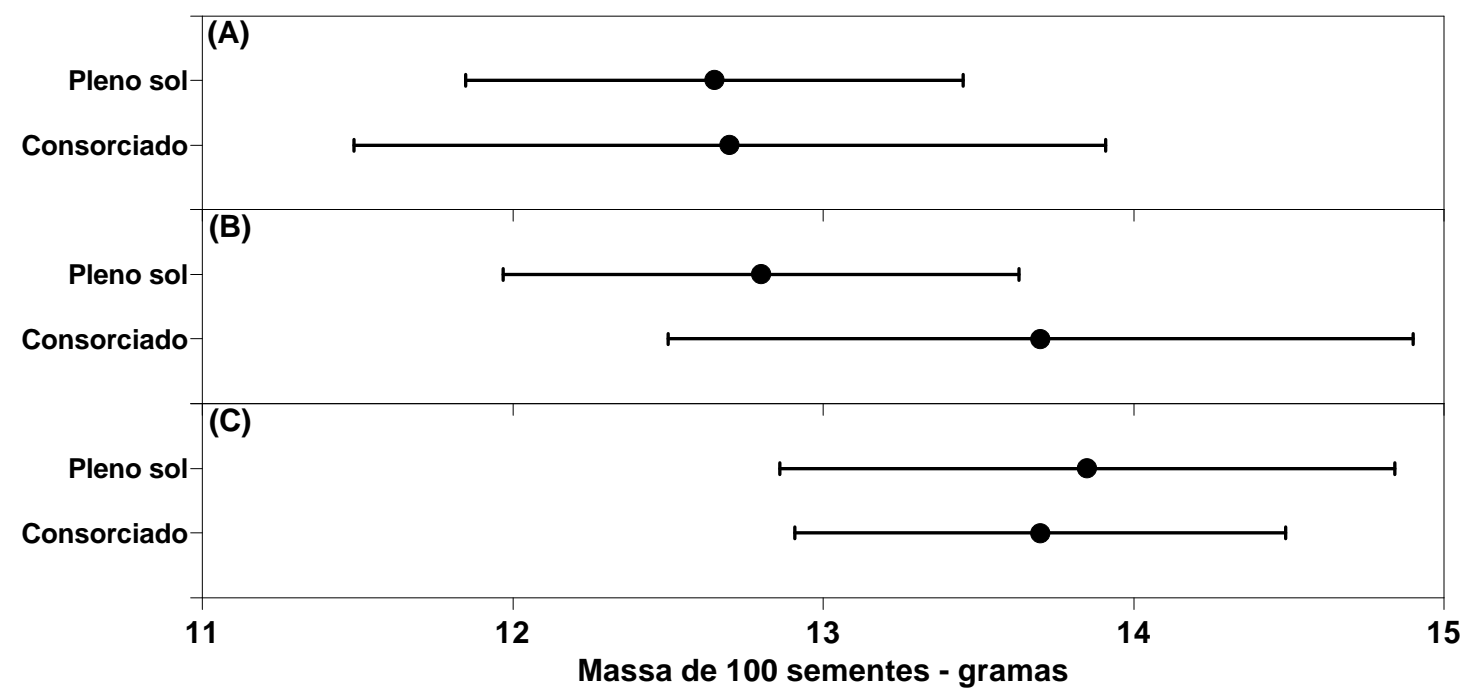

Figura 46 - Massa de 100 sementes (gramas) e intervalos de confiança (95\%), para os sistemas de produção de café a pleno sol e consorciado com banana 'Prata Anã' nos anos de 2002 (A), 2003 (B) e 2004 (C), em Mococa, SP

Em trabalho realizado com sistema de produção de café em consórcio na região de Viçosa, MG, Neves et al. (2001) também não encontraram diferenças entre as produções de sistema consorciado de produção de café com banana e a pleno sol nas primeiras produções, em que pese a grande variabilidade do dados encontrados por esses autores. Lima et al. (2003), em estudos iniciais de sistemas combinados de café com banana, em cultivo orgânico, também na região da zona da mata mineira, não encontraram diferenças significativas nas primeiras produções entre os sistemas.

Em outras regiões aptas para a produção de café, autores como Camargo \& Pereira (1994), Caramori et al. (1996), além de Peeters et al. (2002), relatam que plantios consorciados ou arborizados com atenuações de radiação solar global de até $20 \%$ não produzem efeitos negativos na produção de café. No cultivo consorciado, verificou-se que as bananeiras interceptaram, em média, cerca de $21 \%$ da radiação incidente (Figura 13).

Quando analisados os valores médios das três safras relacionados ao rendimento e à massa de 100 sementes (Figuras 45 e 46), também não foram encontradas diferenças significativas entre os dois sistemas de produção.

Com relação ao rendimento, em 2003 e 2004, os valores médios do sistema pleno sol foram maiores que o sistema consorciado (43,6 e 44,6\% no cultivo a pleno sol e 41,3 e 
$41,9 \%$ no cultivo consorciado, respectivamente). Essa tendência não foi verificada quando analisados os dados da massa de 100 sementes, quando o sistema consorciado apresentou maiores médias nos anos de 2002 e 2003.

Observando os dados obtidos desses dois parâmetros nas três safras, pode se verificar que o ano de 2003 apresentou as maiores diferenças entre os sistemas, embora a baixa produção das parcelas nessa safra tenha provocado grande variabilidade dos dados apresentados, apresentando os maiores valores de intervalo de confiança, principalmente no sistema consorciado.

Em relação aos valores de intervalo de confiança (95\%) dos três índices de produção analisados, em todo o período experimental (Figura 47), ou seja, a produção acumulada (Figura 47A), rendimento médio (Figura 47 B) e massa média de 100 sementes (Figura 47C), também não foram encontradas diferenças estatísticas significativas entre os cultivo de café a pleno sol e consorciado com banana 'Prata Anã'. Os dados de produção e massa de 100 sementes do sistema consorciado apresentam ligeira superioridade em relação ao cultivo a pleno sol. Em contrapartida, o rendimento foi superior no cultivo a pleno sol.

Na Figura 48 são apresentados os dados relativos aos tipos de sementes (chato, moca e concha) para os anos de 2002, 2003 e 2004, bem como a média dos três anos, nos dois sistemas de cultivo. Não houve diferença no comportamento da distribuição dos tipos de sementes entre os dois sistemas de produção de café nas três safras.

Nos anos de 2002 e 2003, a proporção de sementes tipo chato permaneceu próxima de $80 \%$, enquanto o tipo moca em $15 \%$ e o tipo concha, $5 \%$. Na safra de 2004 (Figura 48C) foi verificado um aumento de sementes tipo moca nos dois sistemas de cultivo (próximo a 25\%). Mendes et al. (1954), assim como Monaco (1960), associaram a ocorrência de fatores ambientais adversos na ocasião da florada e início da frutificação, como seca prolongada e deficiência nutricional, com maiores porcentagens de frutos tipo moca. No ano de 2003, após a ocorrência de chuvas em julho, que ocasionaram a quebra de dormência em gemas que determinaram a florada principal em setembro (Figura 43C), sucedeu um período prolongado de seca (Figura 10) que pode ter influenciado essa maior porcentagem de frutos tipo moca na safra colhida em 2004. 

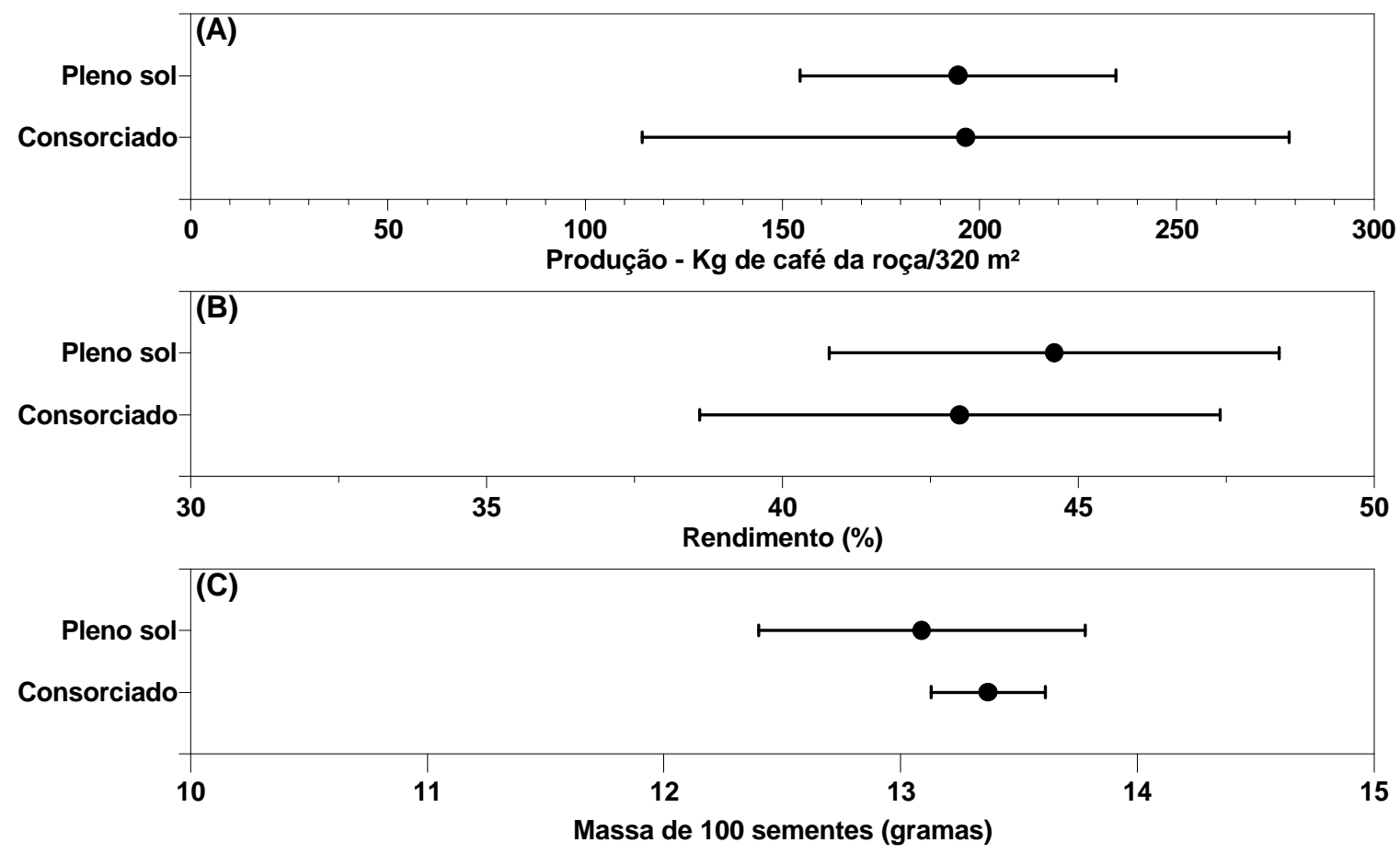

Figura 47 - Produção de café (total dos anos 2002-2004 - A), rendimento (média dos anos 2002-2004 - B) e massa de 100 sementes (média dos anos 2002-2004 - C), e intervalos de confiança (95\%), para os sistemas de produção de café a pleno sol e consorciado com banana 'Prata Anã', em Mococa, SP
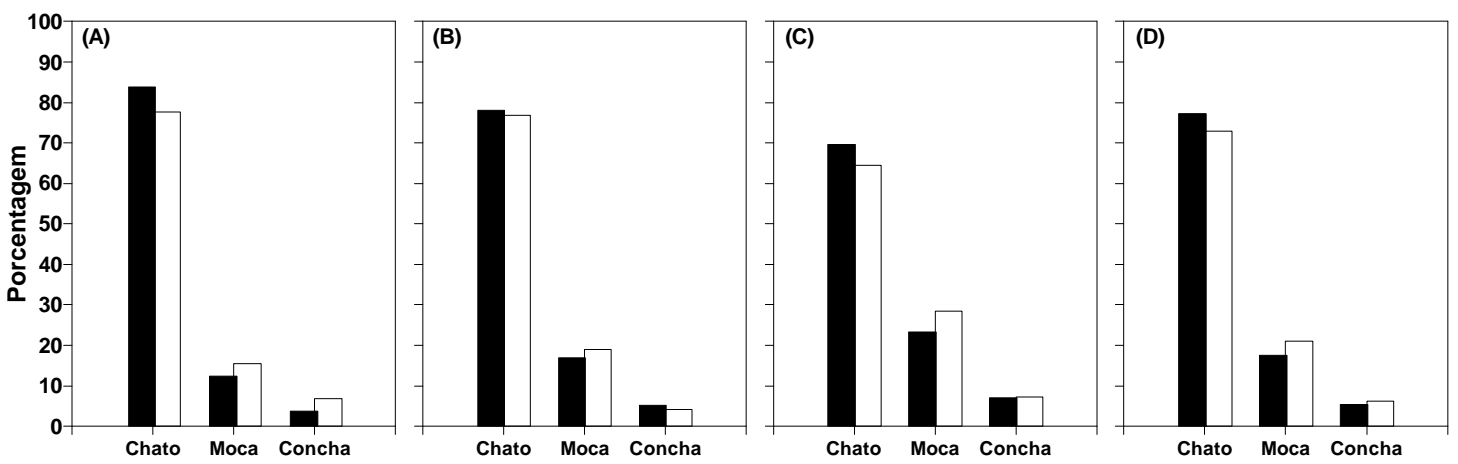

Tipo de semente

Pleno sol $\square$ Consorciado

Figura 48- Distribuição percentual dos tipos de sementes para os sistemas de produção de café a pleno sol e consorciado com banana 'Prata Anã' nos anos de 2002 (A), 2003 (B) e 2004 (C), e médias do período 2002-2004 (B), em Mococa, SP 


\subsubsection{Variabilidade espacial dos índices de produção no cultivo de café consorciado com banana 'Prata Anã'}

$\mathrm{Na}$ Tabela 18 são apresentados os dados médios de produção, em café beneficiado por planta, além do rendimento e massa de 100 sementes para quatro pontos amostrais (Figura 9) do cultivo de café consorciado com banana 'Prata Anã' nos anos de 2002, 2003 e 2004.

Com relação a produção, na colheita realizada no ano de 2002, houve diferença estatística, pelo teste de Tukey, entre o ponto amostral 1 (situado embaixo da bananeira) e os outros pontos amostrais do sistema consorciado. Nos outros anos não foi encontrada diferença estatística, devido aos altos valores de coeficiente de variação, embora o ponto amostral 1 apresentasse menor valor de produção, principalmente no ano de 2004, quando foram obtidas as maiores produções de café beneficiado por planta durante os três anos.

Quando analisado o total de produção das três safras, ocorreu diferença estatística entre o ponto amostral 1 e o ponto amostral 2 (situado entre duas bananeiras), com menor valor de produção para o ponto 1. Os pontos mostrais 3 e 4 (situados na rua intercalar de café entre as ruas de bananeiras) não diferiram entre si e em relação aos outros pontos.

Para o rendimento, embora tenha sido verificada diferença estatística na safra de 2002 , com maior valor $(51,2 \%)$ para o ponto amostral 1 em relação aos pontos 3 e 4 (43,2 e $43,7 \%$, respectivamente), quando analisado os dados médios das três safras não foram encontradas diferenças estatísticas entre os pontos amostrais. Apesar disso o ponto amostral 1 apresentou o maior valor médio de rendimento (48,4\%), enquanto que os outro pontos amostrais apresentaram rendimento médio em cerca de $45 \%$.

Analisando os valores obtidos da massa de 100 sementes, não se observou diferença estatística entre os pontos amostrais, durante os três anos, embora o ponto amostral 1 sempre apresentasse valores superiores em relação a todos os outros pontos amostrados. Quando comparado o dado médio dos três anos, o ponto amostral 1 se mostrou com maior massa de 100 sementes (13,9 gramas) em relação aos pontos 2 e 3 (13,2 e 13,3 gramas, respectivamente). 
Tabela 18. Produção de café (kg de café beneficiado/planta), rendimento (\%) e massa de 100 sementes (gramas) em quatro pontos amostrais no cultivo de café consorciado com banana 'Prata Anã' nos anos de 2002, 2003 e 2004, em Mococa, SP

\begin{tabular}{|c|c|c|c|c|}
\hline Tratamento/Ano & 2002 & 2003 & 2004 & $2001-2004$ \\
\hline & \multicolumn{4}{|c|}{ Produção (Kg de beneficiado/planta) } \\
\hline Ponto amostral 1 & $0,114 b$ & 0,079 & 0,624 & $0,818 b$ \\
\hline Ponto amostral 2 & $0,353 a$ & 0,078 & 0,990 & $1,421 \mathrm{a}$ \\
\hline Ponto amostral 3 & $0,321 \mathrm{a}$ & 0,073 & 0,649 & $1,043 a b$ \\
\hline Ponto amostral 4 & $0,333 \mathrm{a}$ & 0,065 & 0,703 & $1,101 \mathrm{ab}$ \\
\hline $\mathrm{F}$ & $11,74^{\star *}$ & $0,29 \mathrm{~ns}$ & $1,95 \mathrm{~ns}$ & 4,08 * \\
\hline \multirow[t]{2}{*}{ CV (\%) } & 32,91 & 46,37 & 46,18 & 31,77 \\
\hline & \multicolumn{4}{|c|}{ Rendimento (\%) } \\
\hline Ponto amostral 1 & $51,2 \mathrm{a}$ & 45,1 & 48,8 & 48,4 \\
\hline Ponto amostral 2 & $44,7 a b$ & 42,6 & 48,5 & 45,3 \\
\hline Ponto amostral 3 & $43,2 \mathrm{~b}$ & 46,2 & 48,4 & 45,9 \\
\hline Ponto amostral 4 & $43,7 b$ & 45,4 & 46,4 & 45,1 \\
\hline$F$ & $4,39^{\star}$ & $0,69 n s$ & $0,92 \mathrm{~ns}$ & $2,71 \mathrm{~ns}$ \\
\hline \multirow[t]{2}{*}{$\mathrm{CV}(\%)$} & 11,05 & 11,74 & 6,86 & 5,60 \\
\hline & \multicolumn{4}{|c|}{ Massa de 100 sementes (gramas) } \\
\hline Ponto amostral 1 & 12,9 & 14,9 & 13,8 & $13,9 a$ \\
\hline Ponto amostral 2 & 12,7 & 14,1 & 12,9 & $13,2 b$ \\
\hline Ponto amostral 3 & 12,3 & 14,4 & 13,2 & $13,3 \mathrm{~b}$ \\
\hline Ponto amostral 4 & 12,6 & 14,3 & 13,5 & $13,5 a b$ \\
\hline $\mathrm{F}$ & $1,44 n s$ & $2,46 n s$ & $1,60 \mathrm{~ns}$ & 5,41 ** \\
\hline CV (\%) & 4,79 & 4,42 & 6,48 & 2,67 \\
\hline
\end{tabular}

Médias seguidas pela mesma letra, na vertical, não diferem entre si, pelo teste de Tukey a $5 \%$. **: Significativo ao nível de 1\%. *: Significativo ao nível de 5\%. ns: Não Significativo. 
Para os três índices analisados, de uma maneira geral, foi verificado que o ponto amostral 1 diferenciou-se dos demais. Confrontando-se os dados de produção das plantas com o crescimento vegetativo em altura e diâmetro, repetiu-se a tendência apresentada na comparação entre os sistemas de produção. No primeiro ano, o ponto amostral 1 foi o que apresentou, no sistema consorciado, as maiores taxas de crescimento em altura e diâmetro (Figura 42A e 42F), apresentando menor produção (Tabela 18), fato que voltou a se repetir no terceiro ano (Figura 42E e 42J), evidenciando uma competição entre o crescimento vegetativo e o processo de produção (Ortolani et al., 1970).

Outro fator que pode explicar o comportamento do índices de produção do ponto amostral 1 em relação aos demais, foi relativo às diferenças microclimáticas obtidas entre os pontos amostrais do sistema consorciado, principalmente aquela relacionada a transmissividade de radiação solar global, que no ponto 1 variou de 35 a 69\% (Figura 11), enquanto que nos outros pontos amostrais sempre foi superior a $80 \%$ em relação ao cultivo a pleno sol.

Cannell (1976), assim como DaMatta (2004) relatam que em condição de sombreamento excessivo, as plantas de café tendem a apresentar menores produções devido ao maior estímulo à emissão de gemas vegetativas em detrimento das gemas florais e a menor emissão de nós, responsáveis diretos pela produção. Por outro lado, menores produções podem levar um comportamento inverso do rendimento e massa de 100 sementes, com maiores valores desses parâmetros com 0 aumento do sombreamento, fato verificado com os dados médios dos três anos, corroborando com as informações de Camargo \& Pereira (1994).

Na Figura 49 são apresentados os dados relativos aos tipos de sementes para os anos de 2002, 2003 e 2004, bem como a média dos três anos, nos quatro pontos amostrais do sistema consorciado.

Nos dois primeiros anos predominaram as sementes tipo chato em todos os pontos amostrais, a exceção do ponto 3, no ano de 2003 (Figura 49B), onde foi verificado um aumento na incidência de sementes tipo moca. No ano de 2004, assim como na análise do tipo de sementes nos diferentes tipos de cultivo, foi observado um aumento de sementes tipo moca em todos os pontos amostrais.

Quando observada a média dos três anos (Figura 49D), o ponto amostral 1 apresentou cerca de $80 \%$ de sementes tipo chato, enquanto que nos outros pontos essa média permaneceu em torno de $75 \%$. Para as sementes tipo moca, ocorreu uma inversão 
nesses valores, com o ponto amostral apresentando cerca de $15 \%$, enquanto que os outros pontoas amostrais, $20 \%$.
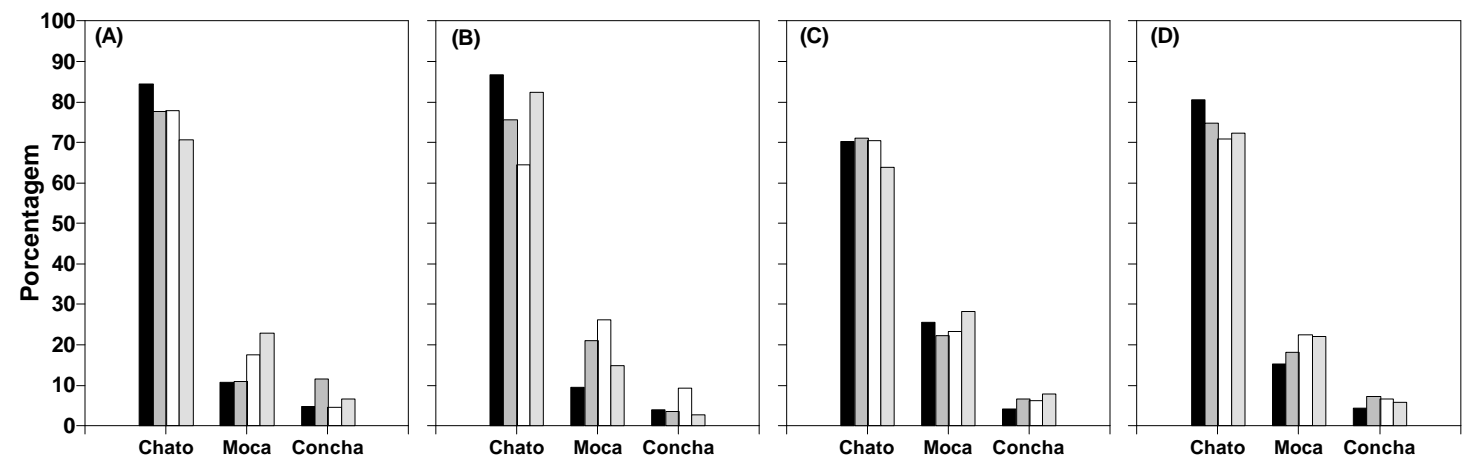

\section{Tipo de semente}

Donto $1 \square$ Ponto $2 \square$ Ponto $3 \quad \square$ Ponto 4

Figura 49 - Distribuição percentual dos tipos de sementes para os diferentes pontos amostrais no cultivo de café consorciado com banana 'Prata Anã' no anos de 2002 (A), 2003 (B) e 2004 (C), e médias do período 2002-2004 (B), em Mococa, SP 


\section{CONCLUSÕES}

Os resultados obtidos nas condições experimentais permitiram chegar às seguintes conclusões:

a) O cultivo consorciado de café promoveu uma atenuação dos valores médios da radiação solar global (21\%) e saldo de radiação (16\%), tendo sido mais evidente no ponto amostral situado próximo as bananeiras.

b) Houve uma redução média de $48 \%$ na velocidade do vento no cultivo consorciado, que foi influenciada pela época do ano e desbaste das bananeiras.

c) Nos diferentes pontos amostrais do cultivo consorciado, não foram encontradas diferenças, em relação ao cultivo a pleno sol, para os valores de temperaturas média e mínima do ar, da umidade relativa e da pressão atual de vapor, em nenhuma época do ano.

d) A temperatura máxima no ponto central da parcela do cultivo consorciado apresentou médias superiores em relação ao cultivo a pleno sol no verão e outono, e em relação ao ponto situado próximo às bananeiras na primavera, verão e outono, tendo sido essas diferenças mais significativas em dias com condição ensolarada e de pouca ocorrência de vento.

e) Nos episódios de resfriamento do ar no período noturno, apesar do cultivo consorciado apresentar menor perda radiativa, principalmente no ponto amostral próximo às bananeiras, ocorreu apenas um acréscimo de apenas $0,3^{\circ} \mathrm{C}$ na temperatura do ar nos episódios amostrados, sendo que para a temperaturas das folhas esses valores atingiram até $0,5^{\circ} \mathrm{C}$. 
f) No cultivo de café consorciado, as plantas de bananeira promoveram um deslocamento do perfil logaritimico da velocidade do vento acima de seu dossel, tendo sido o comportamento dos perfis influenciados pela época do ano e desbaste das bananeiras.

g) A ação de quebra-vento das bananeiras no cultivo consorciado, promoveu alterações nos perfis de temperatura e umidade do ar, apresentando gradientes reduzidos, em relação ao cultivo a pleno sol, acima do dossel dos cafeeiros, tendo sido esse comportamento influenciado pela intensidade do vento.

h) Os valores médios dos componentes do balanço de energia nos sistemas de cultivos de café a pleno sol e consorciado não apresentaram diferenças. Entretanto, houve um comportamento diferenciado entre os sistemas de produção na relação entre evapotranspiração real (Etr) e a evapotranspiração de referência (Eto), em função da época do ano e demanda atmosférica, com maiores valores da relação no cultivo consorciado, principalmente em dias com maior demanda atmosférica ou em episódios no período seco do ano.

i) Nos sistemas de cultivo avaliados, o crescimento, em altura e diâmetro da copa, apresentou maior atividade vegetativa no período primavera-verão em relação ao período outono-inverno, não tendo sido encontradas diferenças significativas das taxas de crescimento, do desenvolvimento fenológico e dos índices de produção.

j) No cultivo consorciado, o ponto amostral próximo às bananeiras, em função do microclima, apresentou diferenças em relação aos demais pontos amostrados no crescimento vegetativo e desenvolvimento fenológico para algumas épocas do ano, além de apresentar menor produção por planta e maior massa de 100 sementes. 
ANEXOS 
Anexo A. Escala de notas para o desenvolvimento fenológico do cafeeiro

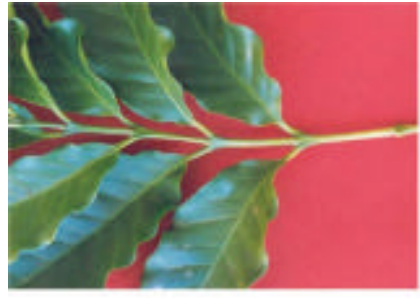

0 - Gema dormente

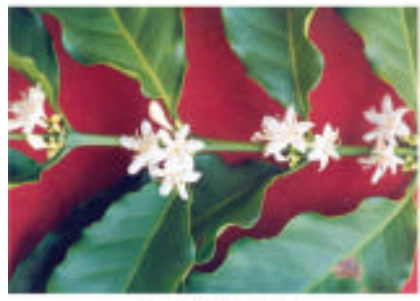

3 - Florada

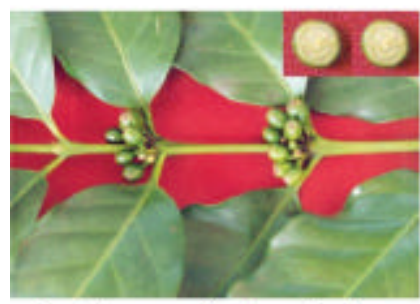

6 - Expansão dos frutos

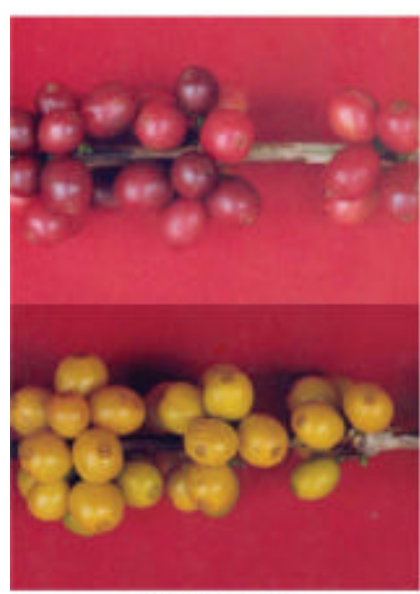

9 - Cereja

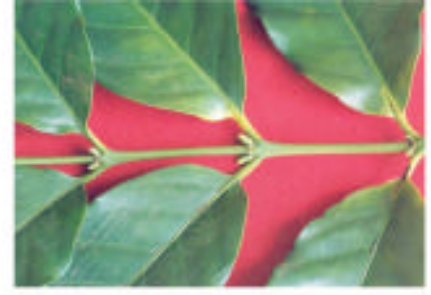

1 - Gema entumecida

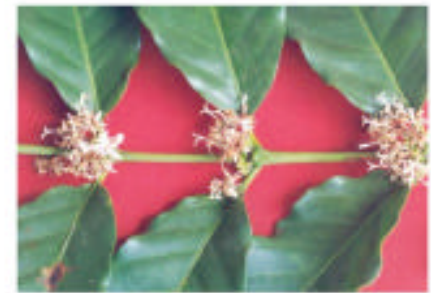

4 - Pós-florada

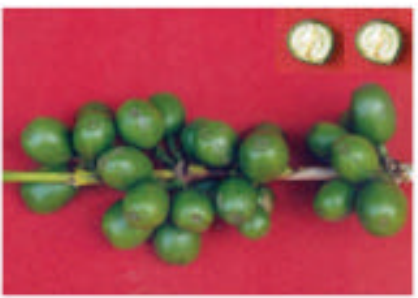

7 - Grăo verde

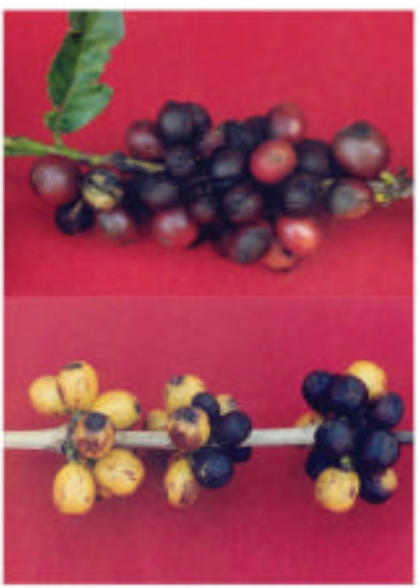

10 - Passa

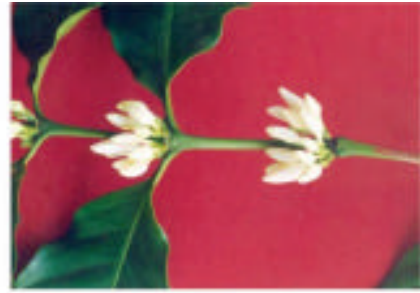

2 - Abotoado

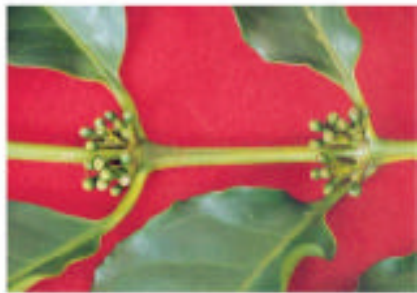

5 - Chumbinho

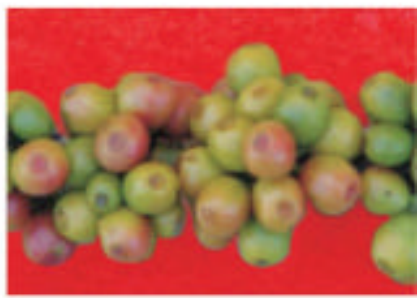

8 - Verde cana

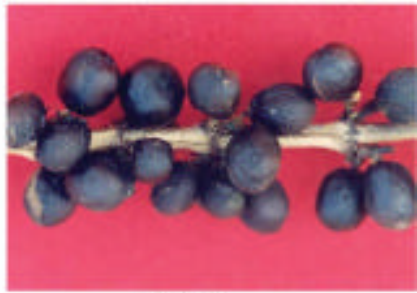

11 - Seco 
Anexo B. Valores mensais de temperatura do ar, radiação solar global, umidade relativa, velocidade do vento e chuva, obtidos no posto meteorológico do Polo Nordeste Paulista, em Mococa, durante o período de outubro de 2001 a junho de 2004

\begin{tabular}{|c|c|c|c|c|c|c|c|c|}
\hline \multirow[t]{2}{*}{ Ano } & \multirow[t]{2}{*}{ Mês } & \multicolumn{3}{|c|}{ Temperatura $\left({ }^{\circ} \mathrm{C}\right)$} & \multirow{2}{*}{$\begin{array}{l}\text { Irradiância } \\
\text { Solar Global } \\
\left(\mathrm{MJ} \cdot \mathrm{m}^{-2} \cdot \mathrm{dia}^{-1}\right)\end{array}$} & \multirow{2}{*}{$\begin{array}{c}\text { Umidade } \\
\text { Relativa } \\
(\%)\end{array}$} & \multirow{2}{*}{$\begin{array}{l}\text { Vento } \\
\left(\mathrm{m} \cdot \mathrm{s}^{-1}\right)\end{array}$} & \multirow{2}{*}{$\begin{array}{r}\text { Chuva } \\
(\mathrm{mm})\end{array}$} \\
\hline & & Máxima & Mínima & Média & & & & \\
\hline \multirow[t]{3}{*}{2001} & Out & 29,3 & 17,4 & 23,4 & 22,8 & 63,0 & 1,80 & 136,8 \\
\hline & Nov & 30,6 & 19,7 & 24,2 & 17,9 & 71,5 & 2,17 & 261,1 \\
\hline & Dez & 29,5 & 19,0 & 23,4 & 18,6 & 75,6 & 2,22 & 207,7 \\
\hline \multirow[t]{12}{*}{2002} & Jan & 30,4 & 19,7 & 24,0 & 20,2 & 77,1 & 2,24 & 371,3 \\
\hline & Fev & 29,2 & 19,3 & 23,2 & 17,5 & 79,7 & 1,99 & 268,8 \\
\hline & Mar & 31,9 & 19,6 & 24,7 & 21,2 & 72,3 & 1,95 & 76,0 \\
\hline & Abr & 32,2 & 17,9 & 24,4 & 20,2 & 62,5 & 1,88 & 1,3 \\
\hline & Maio & 28,2 & 15,5 & 21,1 & 15,0 & 70,0 & 1,84 & 43,8 \\
\hline & Jun & 29,1 & 14,1 & 20,9 & 15,6 & 58,6 & 2,02 & 0,0 \\
\hline & Jul & 27,5 & 12,5 & 19,4 & 14,7 & 59,2 & 2,29 & 2,9 \\
\hline & Ago & 30,4 & 16,7 & 23,0 & 16,7 & 52,0 & 2,55 & 41,7 \\
\hline & Set & 28,6 & 15,9 & 21,8 & 17,2 & 59,7 & 2,63 & 36,6 \\
\hline & Out & 35,4 & 20,0 & 26,9 & 22,2 & 47,5 & 2,77 & 111,6 \\
\hline & Nov & 30,7 & 19,3 & 24,1 & 19,9 & 72,1 & 2,16 & 151,0 \\
\hline & Dez & 31,4 & 20,2 & 24,5 & 20,9 & 75,6 & 2,09 & 244,8 \\
\hline \multirow[t]{12}{*}{2003} & Jan & 29,5 & 20,4 & 23,7 & 16,9 & 81,7 & 1,86 & 462,6 \\
\hline & Fev & 32,3 & 19,6 & 25,2 & 22,9 & 70,4 & 1,87 & 167,0 \\
\hline & Mar & 30,3 & 19,1 & 23,7 & 18,8 & 74,8 & 1,89 & 67,6 \\
\hline & Abr & 29,2 & 17,0 & 22,4 & 17,5 & 73,5 & 1,72 & 100,4 \\
\hline & Maio & 26,0 & 12,8 & 18,9 & 16,3 & 69,2 & 2,04 & 47,6 \\
\hline & Jun & 28,1 & 13,1 & 20,1 & 15,8 & 65,5 & 1,90 & 6,1 \\
\hline & Jul & 26,9 & 12,9 & 19,6 & 15,3 & 55,9 & 2,39 & 10,4 \\
\hline & Ago & 27,5 & 12,6 & 19,5 & 16,3 & 58,9 & 2,15 & 12,4 \\
\hline & Set & 30,7 & 15,9 & 22,8 & 19,3 & 55,4 & 2,69 & 12,2 \\
\hline & Out & 31,0 & 17,6 & 23,9 & 19,2 & 57,9 & 2,48 & 39,6 \\
\hline & Nov & 29,6 & 18,5 & 23,3 & 19,2 & 69,5 & 2,62 & 273,0 \\
\hline & Dez & 30,4 & 20,0 & 24,3 & 20,5 & 74,5 & 2,31 & 215,9 \\
\hline \multirow[t]{6}{*}{2004} & Jan & 29,3 & 19,5 & 23,6 & 19,8 & 76,5 & 2,27 & 218,7 \\
\hline & Fev & 28,8 & 19,1 & 23,0 & 19,3 & 78,3 & 1,93 & 435,1 \\
\hline & Mar & 29,6 & 17,4 & 22,7 & 19,9 & 72,3 & 2,07 & 32,8 \\
\hline & Abr & 28,8 & 17,8 & 22,4 & 16,7 & 75,0 & 1,94 & 100,3 \\
\hline & Maio & 25,2 & 13,9 & 18,8 & 13,2 & 77,7 & 1,83 & 106,9 \\
\hline & Jun & 24,9 & 13,1 & 18,3 & 13,5 & 72,5 & 2,18 & 27,2 \\
\hline
\end{tabular}




\section{REFERÊNCIAS BIBLIOGRÁFICAS}

ALÈGRE, C. Climates et caféiers d'Arabia. Agronomie Tropicale, v. 14, p. 23-58, 1959.

ANGELOCCI, L.R. Estimativa da transpiração máxima de macieiras (Malus spp.) em pomares pelo modelo de Penman-Monteith. Piracicaba, 1996. 103p. tese (LivreDocência) - Escola Superior de Agricultura "Luiz de Queiroz", Universidade de São Paulo.

BAGGIO, A.J.; CARAMORI, P.H.; ANDROCIOLI, A.; MONTOYA, L. Productiviy of southern Brazilian coffee plantations shaded by different stockings of Grevillea robusta. Agroforestry systems, v. 37, n. 2, p.111-120, 1997.

BANZATTO, D.; KRONKA, S.N. Experimentação agrícola. Jaboticabal: FUNEP, 1992. 247p.

BARRADAS, V.L.; FANJUL, L. Microclimatic characterization of shaded and open-grow coffee (Coffea arabica L.) plantations in Mexico. Agricultural and Forest Meteorology, v. 38, p. 101-112, 1986.

BARROS, R.S.; MAESTRI, M. Influência dos fatores climáticos sobre a periodicidade de crescimento vegetativo do café (Coffea arabica L.). Revista Ceres, v. 21, p. 268-279, 1974

BATISTELA SOBRINHO, I.; MATIELLO, J.B.; MIGUEL, A.E. Comportamento de cafeeiros Conilon, Mundo Novo e Catuaí, plantados em mata natural e a pleno sol em Sinop-MT. In: CONGRESSO BRASILEIRO DE PESQUISAS CAFEEIRAS, 14., Campinas, 1987. Trabalhos apresentados. Rio de Janeiro: IBC, 1987. p. 185-186.

BEER, J. Advantages, disadvantages and desirable characteristics of shade trees for coffee, cacao and tea. Agroforestry Systems, v. 5, p. 3-13, 1987.

BEER, J.; MUSCHLER, R.; KASS, D.; SOMARRIBA, E. Shade management in coffee and cacao plantations. Agroforestry Systems, v. 38, p. 139-164, 1998.

BLACK, C.; ONG, C. Utilizations of light and water in tropical agriculture. Agricultural and Forest Meteorology, v. 104, n.1, p. 25-47, 2000. 
BOWEN, I.S. The ratio of heat losses by conduction and by evaporation from any water surface, Physical Review, v. 27, p. 779-787, 1926.

BRENNER, A.J. Microclimatic modifications in agroforestry. In: ONG, C.K.; HUXLEY, P. (Ed.). Tree-crop interactions - A physiological approach. Cambridge: University Press, 1996. cap. 5, p. 159-188.

BRUNINI, O; JANUARIO, M.; FISCH, G.F; CABRAL, O.M. Parâmetros aerodinâmicos de uma cultura de milho. In: CONGRESSO BRASILEIRO DE AGROMETEOROLOGIA, 3., Campinas, 1983. Anais. Campinas: Sociedade Brasileira de Agrometeorlogia, 1983. p.255-264.

BROWN, K.V.; ROSENBERG, N.J. Shelter-effects on microclimate, growth and water use by irrigated sugar beets in the great plains. Agricultural Meteorology, v. 9, p. 241-263, 1972.

CAMARGO, A.P. O clima e a cafeicultura no Brasil. Informe Agropecuário, v. 11, p. 1326, 1985a.

CAMARGO, A.P. Florescimento e frutificação do café arábica nas diferentes regiões cafeeiras do Brasil. Pesquisa Agropecuária Brasileira, v. 20, n.7, p. 831-839, 1985b.

CAMARGO, A. P. de. A arborização como meio de reduzir as adversidades climáticas e promover a sustentação da agricultura. In: CONGRESSO BRASILEIRO DE PESQUISAS CAFEEIRAS, 16., Espirito Santo do Pinhal, 1990. Trabalhos apresentados. Rio de Janeiro: IBC, 1990. p.6-7.

CAMARGO, A.P.; PEDRO JÚNIOR., M.J.; BRUNINI, O.; ALFONI, R.R., ORTOLANI, A.A.; PINTO, H.S. Aptidão ecológica para a cultura do café. In: CHIARINI, J,. V. (Ed.). Zoneamento agrícola do Estado de São Paulo. Campinas: Secretaria da Agricultura, 1977, p. 31-39. v.2

CAMARGO, A.P.; SALATI, E. determinação da temperatura letal de folhagem de cafeeiro em noite de geada. Bragantia, v. 25, p. L61-63, 1966.

CAMARGO, A.P.; SANTINATO, R. Efeitos de concorrência de diferentes espécies arbóreas e arbustivas, como quebra-vento, na formação do cafezal - Parte II. In: CONGRESSO BRASILEIRO DE PESQUISAS CAFEEIRAS, 15., Maringá, 1989. Trabalhos apresentados. Rio de Janeiro: IBC, 1989. p.205-207.

CAMARGO, A.P.; CAMARGO, M.B.P. Definição e esquematização das fases fenológicas do cafeeiro arábica nas condições tropicais do Brasil. Bragantia, v. 60, n. 1, p. 65-68, 2001.

CAMARGO, A.P.; PEREIRA, A.R. Agrometeorology of the coffee crop. World Meteorological Organization. Geneva: WMO/TD, 1994. n. 615, 43 p.

CAMARGO, M.B.P.; CAMARGO, A.P. Representação gráfica informatizada do extrato do balanço hídrico de Thornthwaite \& Mather. Bragantia, v.52, n.2, p.169 - 172, 1993. 
CAMARGO, M.B.P. de; PEDRO JUNIOR, M.J.; CAMARGO, A.P.; FAHL, J.I.; FAZUOLI, L.C.; SANTOS, M.A. Modelo agrometeorológico de estimativa de plena floração do cafeeiro arábica em condições tropicais. In: SIMPÓSIO DE PESQUISAS DOS CAFÉS DO BRASIL, 2., Vitória, 2001. Resumos Expandidos. Brasília: EMBRAPA Café, 2001. p. 173-180.

CAMAYO-VELEZ, G.C.; CHAVES-CORDOBA, B, AREILA-PULGARIN, J., JARAMILLOROBLEDO, A. Desarrollo floral del cafeto y su relacion com las condiciones climáticas de Chinchina-Caldas. Cenicafé, v. 54, n. 1, p. 35-49, 2003.

CANNELL, M.G.R. Crop physiological aspects of coffee bean yield - a review. Kenya Coffee, v. 41, p. 245-253, 1976

CARAMORI, P.H. Arborização dos cafezais para proteção contra geadas na região Sul do Brasil. In: REUNION ARGENTINA DE AGROMETEOROLOGIA, 7., Buenos Aires, 1997. Actas. Buenos Aires: UBA, 1997. p.17-18.

CARAMORI P.H.; MANETTI FILHO, J. Proteção dos cafeeiros contra geadas.Londrina: IAPAR. 1993. 27 p. (IAPAR. Circular Técnica, no 79).

CARAMORI, P.H.; MORAIS, H. Proteção de cafezais recém-implantados contra geada através do plantio intercalar de espécies anuais. In: CONGRESSO BRASILEIRO DE PESQUISAS CAFEEIRAS, 25., Franca, 1999. Trabalhos apresentados. Rio de Janeiro: PROCAFE, 1999. p.111-112.

CARAMORI, P.H.; ANDROCIOLI FILHO, A.; LEAL, A.C. Coffee shade with Mimosa scabrella Benth. for frost protection in southern Brazil. Agroforestry Systems, v. 33, p. 205-214, 1996.

CARAMORI, P.H.; LEAL, A.C.; MORAIS, H. Temporary shading of young coffee plantatios with pigeonpea (Cajanus cajan) for frost protection in southern Brazil. Revista Brasileira de Agrometeorologia, v.7, n.2, p. 195-200, 1999.

CARAMORI, P.H.; OMETTO, J.C.; VILLA NOVA, N.A.; COSTA, J.D. Efeitos do vento sobre mudas de cafeeiro Mundo Novo e Catuaí Vermelho. Pesquisa Agropecuária Brasileira, v. 21, n. 11, p. 1113-1118, 1986.

CARAMORI, P.H.; LEAL, A.L.; MORAIS, H.; MOREIRA, I.A. Proteção temporária de cafezal em formação contra geadas com espécies anuais e semi-perenes. In: SIMPÓSIO DE PESQUISAS DOS CAFÉS DO BRASIL, 1., Poços de Caldas, 2000. Resumos Expandidos. Brasília: EMBRAPA Café, 2000. p. 83-85.

CARAMORI, P.H.; MORAIS, H.; ANDROCIOLI FILHO, A.; LEAL, A.C.; GORRETA, R.; CRUZ, R.F.R. Utilização de espécies intercalares ao cafezal para proteção contra geadas: Resultados e perspectivas. In: SIMPÓSIO DE PESQUISAS DOS CAFÉS DO BRASIL, 2., Vitória, 2001. Resumos Expandidos. Brasília: EMBRAPA Café, 2001. p. 242-246. 
CARELLI, M.L.C.; FAHL, J.I.; TRIVELIN, P.C.O.; QUEIROZ-VOLTAN, R.B. Carbon isotope discrimination and gas exchange in Coffe species grown under differenmt irradiance regimes. Revista Brasileira de Fisiologia Vegetal, v. 11, n. 2, p.63-68, 1999.

CARNEIRO FILHO, F.; CAMARGO, A.P. Observações preliminares sobre arborização em cafezal no Paraná. In: CONGRESSO BRASILEIRO DE PESQUISAS CAFEEIRAS, 14., Campinas, 1987. Trabalhos apresentados. Rio de Janeiro: PROCAFE, $1987 . \quad$ p. 6566.

CARVALHO, A.; KRUG, C.A.; MENDES, J.E.T.; ANTUNES FILHO, H.; JUNQUEIRA, A.R.; ALOISI SOBRINHO, J.; ROCHA, T.R.; MORAES, M.V. Melhoramento do cafeeiro. XXI - Comportamento regional de variedades, linhagens e progênies de café ao sol e à sombra. Bragantia, v. 20, p. 1045-1142, 1961.

COSTE, R. El café. Barcelona: Editorial Blume, 1969. 285 p.

CORLETT, J.E.; ONG, C.K.; BLACK, C.R.; MONTEITH, J.L. Above and below-ground interactions in a leucaena/millet alley cropping system. 1. Experimental design, instrumentation and diurnal trends. Agricultural and Forest Meteorology, v. 60, p. 5372, 1992.

DAMATTA, F.M. Ecophysiological constraints on the production of shaded and unshaded coffee: a review. Field Crops Research, v. 86, p. 99-114, 2004.

DAMATTA, F.M.; RENA, A.B. Ecofisiologia de cafezais sombreados e a pleno sol. In: ZAMBOLIM, L. (Ed.). O estado da arte e tecnologia na produção de café. Viçosa: UFV, 2002. p. 93-135.

DANTAS, F.S.; MATIELLO, J.B.; CAMARGO, A.P. Arborização do cafeeiro com Greville robusta na Região serrana de Pernambuco. In: CONGRESSO BRASILEIRO DE PESQUISAS CAFEEIRAS, 16., Espirito Santo do Pinhal, 1990. Trabalhos apresentados. Rio de Janeiro: IBC, 1990. p. 130-131.

EMPRESA BRASILEIRA DE PESQUISA AGROPECUÁRIA. Sistema Brasileiro de classificação de solos. Brasília: Centro Nacional de Pesquisa de Solos, 1999. 412 p.

FAHL, J.I.; CARELLI, M.L.C.; VEGA, J; MAGALHÃES, A.C. Nitrigen and irradiance affecting net photosynthesis and growth of young coffee plants (Coffea arabica L.) Journal of Horticultural Science, v. 69, p. 161-169, 1994.

FANCELLI, A.L.; DOURADO-NETO, D. Ecofisiologia e fenologia do feijoeiro. In: FANCELLI, A.L.; DOURADO-NETO, D. (Ed.) Tecnologia da produção do feijão irrigado, 2. ed. Piracicaba: Publique, 1997, p. 1-20.

FARFAN-VALENCIA, F.; ARIAS-HERNANDEZ, J.J.; RIANO-HERRERA, N.M. Deasarrollo de una metodologia para medir sombrio en sistemas agroflorestales com café. Cenicafé, v. 54, n.1, p. 24-34, 2003. 
FAZUOLI, L.C. Avaliação de progênies de café Mundo Novo (Coffea arabica L.). Piracicaba, 1977. 146p. Dissertação (Mestrado) - Escola Superior de Agricultura "Luiz de Queiroz", Universidade de São Paulo.

FERNANDES, D.R. Manejo do cafezal. In: RENA, A.B.; MALAVOLTA, F.; ROCHA, M.; YAMADA, T. (Ed.). Cultura do cafeeiro: fatores que afetam a produtividade. Piracicaba: POTAFOS, 1986. p. 275-301.

FRANCO, C.M.; INFORZATO, R. Quantidade de água transpirada pelo cafeeiro sombreado e pelo ingazeiro. Bragantia, v. 11, p. 121-125, 1951.

FRANCO, C.M. Descoloração em folhas de cafeeiros, causada pelo frio. Bragantia, v. 15, p. 131-135, 1956.

FRANCO, C.M. Lesão do colo do cafeeiro causada pelo calor. Bragantia, v. 20, p. 345652, 1961.

GOBBI, J.A. Is biodiversity-friendly coffee financially viable? $\mathrm{Na}$ analysis of five different coffe production systems in western El Slavador. Ecological Economics, v. 33, p. 267-281, 2000.

GOPAL, N.H.; RAMAIAH, P.K.; NARASIMHASWAMY, R.L. Shade for arabica coffe in India. Indian Coffee, v. 34, p. 265-267, 1970.

GOUVEIA, N.M. Estudo da diferenciação e crescimento das gemas florais de Coffea arabica L.: observações sobre antese e maturação dos frutos. Campinas, 1984. 237 p. Dissertação (Mestrado) - Instituto de Biologia, Universidade Estadual de Campinas.

GUTIERREZ, M.V.; MEINZER, F.C. Energy balance and latent heat flux in coffee hedgerows at different stages of canopy development. Agricultural and Forest Meteorology, v. 68, p. 173-186, 1994.

GUTIERREZ, M.V.; MEINZER, F.C.; GRANTZ, D.A. Regulation of transpiration in coffee hedgerows: covariation of environmental variables and apparent responses of stomata to wind and humidity. Plant Cell Environmental, v. 17, p. 1305-1313, 1994.

JARAMILLO-ROBLEDO. Perfil de viento en cafetales al sol. Cenicafé, v. 26, n.3, p. 142147, 1975.

JARAMILLO-ROBLEDO, A. Aspectos microclimaticos en plantaciones de café (Coffea arabica L.) com alta densidad de siembra. In: SIMPÓSIO INTERNACIONAL SOBRE CAFÉ ADENSADO, 1., Londrina, 1994. Anais. Londrina: IAPAR, 1994. p. 47-69.

JARAMILLO-ROBLEDO, A.; GOMEZ-GOMEZ, L. Microclima en cafetale a libre exposicion solar y bajo sombrio. Cenicafé, v. 40, n. 3, p. 65-79, 1989.

KUSTAS, W.P.; CHOUDHURY, B.J.; KUNKEL,K.; GAY, L.W. Estimate of the aerodinamic roughness parameters over an incomplete canopy cover of cotton. Agricultural and Forest Meteorology, v. 46, p. 91-105, 1989. 
LEUNING, R.; CREMER, K.W. Leaf temperatura during radiation frost. pt 1. Agricultural and Forest Meteorology, v. 42, p. 121-133, 1988.

LIBARDI, V.C.M.; SILVA, F.C.; FUKUSHIMA, E..H; FOLEGATTI, M.V. Efeitos dos fatores climáticos na taxa de crescimento do cafeeiro (Coffea arabica L.). In: CONGRESSO BRASILEIRO DE AGROMETEOROLOGIA, 9., Campinas Grande, 1995. Anais. Campina Grande: Sociedade Brasileira de Agrometeorologia, 1995. p.247-249.

LIMA, P.C.; MOURA, W.M.; PEREIRA, A.A.; RIBEIRO, P.M. Unidades experimentais de cafeeiros sob sistema de produção orgânica no município de Heliodora, Minas Gerais. In: SIMPÓSIO DE PESQUISAS DOS CAFÉS DO BRASIL, 3., Porto Seguro, 2003. Anais. Brasília: EMBRAPA Café, 2003. p. 438-439.

MACEDO, R.L.G.; GIMES, J.E.; OLIVEIRA, T.K.; DANTAS, F.W.F. Compatibilidades climáticas, vegetativas, edáficas/nutricionais e fitossanitárias dos sistemas agroflorestais permanentes com cafeeiro e seringueira. In: CONGRESSO BRASILEIRO DE PESQUISAS CAFEEIRAS, 27., Uberaba, 2001. Trabalhos apresentados. Rio de Janeiro: PROCAFE, 2001. p. 252-253.

MALEK, E.; BINGHAM, G.E. Growing season evapotranspiration and crop coefficient. In: ALLEN, R.G.; VAN BAVEL, C.M.U. (Ed.). Management of irrigation and drainage systems: integrated perspectives. New York: ASCE, 1993. p. 961-968.

MARIN, F.R. Evapotranspiração e transpiração máxima em cafezal adensado. Piracicaba, 2003. 118 p. Tese (Doutorado) - Escola Superior de Agricultura "Luiz de Queiroz", Universidade de São Paulo.

MARIN, F.R.; ANGELOCCI, L.R.; COELHO FILHO, M.A.; VILLA NOVA, N. Construção e avaliação de psicrômetro aspirado de termopar. Scientia Agrícola, v. 58, n. 4, p. 839844, 2001.

MARIN, F.R.; ANGELOCCI, L.R.; RIGHI, E.Z.; SENTELHAS, P.C. Evapotraspiration and crop coefficientes of a coffee plantation in southern Brazil (compact disc). In: REUNIÃO ARGENTINA DE AGROMETEOROLOGIA, 10., Mar del Plata, 2004. Trabalhos apresentados. Buenos Aires: Universidade de Buenos Aires, 2004.

MARIN, F.R.; ANGELOCCI, L.R.; PEREIRA, A.R.; SENTELHAS, P.C.; VILLA NOVA, N.A. Balanço de energia e consumo hídrico em pomar de lima ácida "Tahiti". Revista Brasileira de Meteorologia, v. 17, n.2, p. 219-228, 2002.

MATIELLO, J.B.; FERNANDES, D.R. Observações sobre arborização de cafezais em regiões de Chapada, na Bahia.In: CONGRESSO BRASILEIRO DE PESQUISAS CAFEEIRAS, 15., Maringá, 1989. Anais. Rio de Janeiro: IBC, 1989. p. 238-240.

MATIELLO, J.B.; ALMEIDA, S.R. Sistemas de combinação de café com seringueira, no sul de Minas Gerais. In: CONGRESSO BRASILEIRO DE PESQUISAS CAFEEIRAS, 17., Varginha, 1991. Trabalhos apresentados. Rio de Janeiro: MARA/SNPA/EMBRAPA, 1991. p. 112-114. 
MATIELLO, J.B.; ALMEIDA, S.R. Observações sobre sistemas de arborização a longo prazo em cafezais de sul de Minas. In: CONGRESSO BRASILEIRO DE PESQUISAS CAFEEIRAS, 27., Uberaba, 2001. Trabalhos apresentados. Rio de Janeiro: PROCAFE, 2001. p. 62-63

MATIELLO, J.B.; DANTAS, F.A.S.; CAMARGO, A.P. de; RIBEIRO, R.N.C. Níveis de sombreamento em cafezal na região serrana de Pernambuco. Parte III. In: CONGRESSO BRASILEIRO DE PESQUISAS CAFEEIRAS, 15., Maringá, 1989. Resumos. Rio de Janeiro: IBC, 1989. p. 182.

MATIELLO, J.B.; BARROS, U.V.; GARÇON, C. Arborização de cafeeiros com bananeiras na região de altitude elevada na cafeicultura de montanha - Resultados iniciais na produção e sobre Phoma. In: CONGRESSO BRASILEIRO DE PESQUISAS CAFEEIRAS, 27., Uberaba, 2001. Trabalhos apresentados. Rio de Janeiro: PROCAFE, 2001. p. 21-22.

MATIELLO, J.B.; SANTINATO, R.; GARCIA, A.W.R.; ALMEIDA, S.R.; FERNANDES, D.R. Cultura de Café no Brasil: Novo Manual de Recomendações. Rio de Janeiro: MAPA/PROCAFE. 2002. 388p.

MATSUMOTO, S.N.; FARIA, G.O.; VIANA, A.E.S.; PINTO, F.R.S. Efeito do sombreamento de grevilhas em cafezais no sudoeste da Bahia. In: SIMPÓSIO DE PESQUISA DOS CAFÉS DO BRASIL, 1., Poços de Caldas, 2000. Resumos Expandidos. Brasília: EMBRAPA Café, 2000. p. 1010-1013.

MENDES, A.J.T.; MEDINA, D.M.; CONAGIN, C.H.T.M. Citologia da ocorrência de frutos sem sementes no café Mundo Novo. Bragantia, v.13, p. 257-279, 1954.

Miguel, A.E.; MATIELLO, J.B.; CAMARGO, A.P.; ALMEIDA, S.R.; GUIMARÃES, S.R. Efeitos da arborização do cafezal com Grevillea robusta nas temperaturas do ar e umidade do solo, Parte II. In: CONGRESSO BRASILEIRO DE PESQUISAS CAFEEIRAS, 21., Rio de Janeiro, 1995. Trabalhos apresentados. Rio de Janeiro: PROCAFE, 1995. p. 55-60

MONACO, L.C. Efeito das lojas vazias, sobre o rendimento do café Mundo Novo. Bragantia, v. 19, n.1, p. 1-12, 1960.

MONTEITH, J.L., Gas exchanges in plant cpmmunities. In: EVANS, L.T. (Ed.) Environmental Control of Plant Growth. Camberra: Academic Press, 1963. p. 95-111.

MONTEITH, J.L.; ONG, C.K.; CORLETT, J.E. Microclimatic interactions in agroforestry systems. Forest Ecology and management, v. 45, p. 31-44, 1991.

MORAIS, H.; CARAMORI, P.H., Consorciação de café recepado com guandu (Cajanus cajan) durante o inverno para proteção de cafezais contra geadas. In: SIMPÓSIO DE PESQUISAS DOS CAFÉS DO BRASIL, 2., Vitória, 2001. Resumos Expandidos. Brasília: EMBRAPA Café, 2001. p. 242-246. 
MORAIS, H.; MARUR, C.J.; CARAMORI, P.H.; RIBEIRO, A.M.A.; GOMES, J.C. Características fisiológicas e de crescimento de cafeeiro sombreado com guandu e cultivado a pleno sol. Pesquisa Agropecuária Brasileira, v. 38, n. 10, p. 1131-1137, 2003

MOREIRA, R.S. Banana: Teoria e práticas de cultivo. Campinas: Fundação Cargill. 1987. $335 \mathrm{p}$.

MUSCHLER, R. Shade or sun for ecologically sustainble coffee production: a summary of environmental key factors. In: SEMANA CIENTIFICA DEL CENTRO AGRONOMICO TROPICAL DE INVESTIGACION Y ENSEÑANZA (CATIE), 3., Turrialba, 1997. Turrialba: CATIE, 1997. p. 109-112.

NAIR, P.K.R. Agroforestry systems in major ecological zones of the tropics and subtropics. In: THE APPLICATION OF METEOROLOGY TO AGROFORESTRY SYSTEMS PLANNING AND MANAGEMENT, 1., Nairobi, 1987. Proceedings. Nairobi: ICRAF, 1989. p 57-96.

NEVES, Y.P.; MARTINEZ, H.E.P.; SOUZA, C.M.; CECON, P.R. Crescimento e produção de Coffea arabica, fertilidade do solo e retenção de umidade em sistema agroflorestal. In: SIMPÓSIO DE PESQUISAS DOS CAFÉS DO BRASIL, 2., Vitória, 2001. Resumos Expandidos. Brasília: EMBRAPA Café, 2001. p. 1678-1686.

OLIVER, H.R.; SENE, K.J. Energy and water balances of developing vines. Agricultural and Foret Meteorology, v. 61, n.2, p. 167-185, 1992.

ONG, C.K.; CORLETT, J.E.; SINGH, R.P.; BLACK, C.R. Above and below groun interactions in agroforestry systems. Forest Ecology Management, v. 45, p. 45-57, 1991.

ORTOLANI, A.A.; PINTO, H.S.; PEREIRA, A.R.; ALFONSI, R.R. Parâmetros climáticos e a cafeicultura. Rio de Janeiro: IBC, 1970. 22p. (Relatório preliminar)

PEETERS, L.Y.K.; SOTO-PINTO, L.; PERALES, H.; MONTOYA, G.; ISHIKI, M. Coffee production, timber, and firewood in traditional and Inga-shaded plantations in Southern Mexico. Agriculture, Ecossystems and Environment. , v. 82, p. 1-13, 2002.

PEDRO JUNIOR, M.J. Balanço de energia em soja. Piracicaba, 1977. 82 p. Dissertação (Mestrado) - Escola Superior de Agricultura "Luiz de Queiroz", Universidade de São Paulo.

PEDRO JUNIOR, M.J.; MAGALHÃES, H.H.S. Microlcima da cultura da soja. Ecossistema, v.7, p. 68-73, 1982

PENMAN, H.L.; LONG, I.F. Weather in wheat: an essay in micro-meteorology. Quaterly Journal of the Royal Meteorological Society, v. 86, p. 17-50, 1960.

PEREIRA, A.R. Introdução a micrometeorologia. Piracicaba: ESALQ/USP; Departamento de Física e meteorologia, 1996. 70 p. 
PEREIRA, A. R.; VILLA NOVA, N. A.; SEDYAMA, G.C. Evapotranspiração. Piracicaba: FEALQ, 1997, 183p.

PEREIRA, A.R.; ANGELOCCI, L.R.; SENTELHAS, P.C. Agrometeorologia: Fundamentos e Aplicações. Guaiba: Agropecuária, 2002. 478 p.

PEREIRA, A.R.; MARIN, F.R.; ANGELOCCI, L.R.; VILLA NOVA, N.A.; SENTELHAS, P.C., Difficulties with micrometeorological methods in a small citrus orchads. Revista Brasileira de Meteorologia, v. 18, n. 1, p. 13-20, 2003.

PEREIRA, A.V.; PEREIRA, E.B.C.; FIALHO, J.F.; JUNQUEIRA, N.T.V.; MACEDO, R.L.G.; GUIMARÃES, R.J. Sistemas agroflorestais de seringueira com cafeeiro. Planaltina: EMBRAPA-CPAC, 1998. 77p. (EMBRAPA-CPAC. Documentos, 70)

PERFECTO, I.; VANDERMEER, J. Microclimatic changes and the indirest loss of ant diversity in a tropical agroecosystem. Oecologia, v. 108, n. 3, p. 577-582, 1996.

PEZZOPANE, J.E.M. Caracterização microclimática, ecofisiológica e fitossociológica em uma floresta estacional semidecidual secundária em Viçosa, MG. Viçosa, 2001. 255 p. Tese (Doutorado) - Universidade Federal de Viçosa.

PEZZOPANE, J.R.M.; GALLO, P.B.; PEDRO JÚNIOR, M.J. Radiação solar global, saldo de radiação e fluxo de calor no solo em cultivo consorciado café/coqueiro-anão verde. In: SIMPÓSIO DE PESQUISA DOS CAFÉS DO BRASIL, 2., Vitória, 2001. Resumos Expandidos. Brasília: EMBRAPA Café, 2001. p. 206-213.

PEZZOPANE, J.R.M.; PEDRO JÚNIOR, M.J. Balanço de energia Balanço de energia em vinhedo de "Niagara rosada". Bragantia, v. 62, n. 1, p.155-161, 2003.

PEZZOPANE, J.R.M.; GALLO, P.B.; PEDRO JÚNIOR, M.J.; ORTOLANI, A.A. Caracterização microclimática em cultivo consorciado café/coqueiro-anão verde. Revista Brasileira de Agrometeorologia, v. 11, n. 2, p. 293-302, 2003a.

PEZZOPANE, J.R.M., PEDRO JÚNIOR, M.J., THOMAZIELLO, R.A., CAMARGO, M.B.P. Escala para avaliação de estádios fenológicos do cafeeiro Arábica. Bragantia, v. 62, n.3, p.499-505, 2003b.

PRUEGER, J.H.; HATFIELD, J.L.; SAUER, T.J. Surface energy balance partitioning over rye and oats cover crops in central lowa. Journal of Soil and Water Conservation, v. 53, n. 3, p. 263-268, 1998.

RENA, A.B.; MAESTRI, M. Fisiologia do cafeeiro. Informe Agropecuário, v. 11, p. 26-40, 1985.

RIGHI, E.Z.; MARIN, F.R.; ANGELOCCI, L.R.; CICHOTA, R.; FAVARIN, J.L. Efeito da velocidade do vento no deslocamento do plano zero e no comprimento da rugosidade em cafezal em crescimento. In: CONGRESSO BRASILEIRO DE AGROMETEOROLOGIA, 13., Santa Maria, 2003. Anais. Santa Maria: Sociedade Brasileira de Agrometeorologia, 2003. p.177-178. 
ROMERO-ALVARADO, Y.; SOTO-PINTO, L.; GARCIA-BARROS, L.; BARRERAGAYTAN, F. Coffee yields and soli nutrientes under the shades of Inga sp. vs. multiple species ins Chiapas, Mexico. Agroforestry Systems, v. 54, p. 215-224, 2002.

ROSEMBERG, N.J. Microclimate: The Biological environment. New York: JOHN WILEY \& SONS, 1974, 315p.

RUSSO JÚNIOR, M. Dados climáticos auxiliares para planejamento e projeto de sistemas de irrigação. São Paulo: CESP, 1980. 13p.

SÁ, T.D.A. Aspectos climáticos associados a sistemas agroflorestais: implicações no planejamento e manejo em regiões tropicais. In: CONGRESSO BRASILEIRO DE SISTEMAS AGROFLORESTAIS, 1., Porto Velho, 1994. Trabalhos apresentados. Colombo: EMBRAPA, 1994. p. 391-431.

SCHALLER, M.; SCHROTH, G.; BEER, J.; JIMENEZ, F. species and site characteristics that permit the association of fast-growing trees with crops: the case of Eucalyptus deglupta as coffee shade in Costa Rica. Forest Ecology and Management, v. 175, p. 205-215, 2003.

SENTELHAS, P.C.; NASCIMENTO, A.L.C. Variação sazonal da relação entre o saldo de radiação e a radiação solar global. Revista Brasileira de Meteorologia, v. 18, n. 1, p. 71-77, 2003.

SENTELHAS, P.C.; PEDRO JUNIOR, M.J.; MARTINS, F.P. Características aerodinâmicas da videira conduzida em espaldeira. Revista Brasileira de Agrometeorolgia, v. 1, p. 25-30, 1993

SENTELHAS, P.C.; FAZUOLI, L.C.; PEZZOPANE, J.R.M. Temperatura letal de diferentes espécies e derivados de híbrido interespecífico de café. In: CONGRESSO BRASILEIRO DE PESQUISAS CAFEEIRAS, 21., Araxá, 1995. Resumos. Rio de Janeiro: MARA, 1995. p. 156-157.

SHAW, R.H.; PEREIRA, A.R. Aerodynamic roughness of a plant canopy: a numerical experiment. Agricultural Meteorology, v.26, p. 51-65, 1982

SILVA, V.P.; VIEIRA, A.R.R., CARAMORI, P.H., BAGGIO, A.J. A radiação fotossinteticamente ativa e a produção de pastagem em sistema pastoril (compact disc). In: CONGRESSO BRASILEIRO DE AGROMETEOROLOGIA, 11., Florianópolis (SC), 1999. Anais. Florianópolis: Sociedade Brasileira de Agrometeorologia, 1999.

SOTO-PINTO, L.; PERFECTO, I.; CASTILLO-HERNANDEZ, J.; CABALLERO NETO, J. Shade effect on coffee production at the norther Tzeltal zone of the state of Chiapas, Mexico. Agriculture, Ecosystems \& Environment, v. 80, p. 61-69, 2000.

STIGTER, C.J.; MOHAMMED, A.E.; AL-AMIN, N.K.N.; ONYEWOTU, L.O.Z.; OTENG, S.B.B.; KAINKWA, R.M.R. Agroforestry solutions to some African wind problems. Journal of wind Engineering and Industrial Aerodynamics, v. 90, p. 1101-1114, 2002 
THOMAZIELLO, R.A.; FAZUOLI, L.C.; PEZZOPANE, J.R.M.; FAHL,J.I.; CARELLI, M.L.C. Café Arábica: Cultura e técnicas de produção. Instituto Agronômico, Campinas. Boletim Técnico no 187, 82p., 2000.

TORRADO, P. V. Relações soloxrelevo em Mococa (SP). Influência das características topográficas e posição na vertente no atributos do sol. . Piracicaba, 1989. 205 p. Dissertação (Mestrado) - Escola Superior de Agricultura "Luiz de Queiroz", Universidade de São Paulo.

UCHIMA, Z. Microclimate of rice. In: SYMPOSIUM ON CLIMATE AND RICE, 1976. Proceedings, The International Rice Research Institute, 1976, p. 115-140

UJAH, J.E.; ADEOYE, K.H. Effects of shelterbelts in the Sudan Savanna zone of Nigeria on microclimate and yield of millet. Agricultural and Forest Meteorology, v. 33, n. 2/3, p. 99-107, 1984.

VANDENBELDT, R.J.; WILLIAMS, J.H. The effect of soil surface temperature on the growth of millet in relation to the effect of Faidherbia albida trees. Agricultural and Forest Meteorology,v. 60, p. 93-1000, 1992

VIANELLO, R.L.; ALVES, A.R. Meteorologia básica e aplicações. Viçosa: Imprensa Universitária, 1991. 449p.

VIEIRA, S. Introdução à bioestatística Rio de Janeiro: Elsevier. 1980. 196p.

VILAVICENCIO-ENRIQUEZ, L.; VALDEZ-HERNANDEZ, J.I. Analisys of tree structure in the traditional coffee agroforestry system in San Miguel, Veracruz, Mexico. Agrociencia, v. 37, n. 4, p. 413-423, 2003.

VILLA NOVA, N.A. Estudos sobre o balanço de energia em cultura de arroz. Piracicaba, 1973. 78p. Tese (Livre-Docência) - Escola Superior de Agricultura "Luiz de Queiroz", Universidade de São Paulo.

WALLACE, J.S. The water balance of mixed tree-crop systems. In: ONG, C.K., HUXLEY, P. (Ed.) Tree-crop interactions - A physiological approach. Cambridge: University Press, 1996. cap. 6, p. 189-234.

WILLEY, R.W. The use of shade in coffe, cocoa and tea. Horticultural Abstracts, v. 45, n. 12, p. 791-798, 1975. 